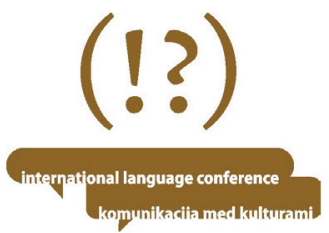

10th International Language Conference on the

"Importance of Learning Professional Foreign Languages for Communication between Cultures", 20 and 21 September 2018, Celje, Slovenia

\title{
CONFERENCE PROCEEDINGS
}

Editors:

Polona Vičič, PhD Nataša Gajšt, MA Alenka Plos, MSc

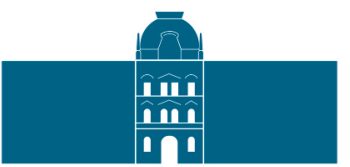

University of Maribor Press 

Faculty of Logistics

$10^{\text {th }}$ International Language Conference on

\section{"The Importance of Learning Professional Foreign Languages for Communication between Cultures«}

20 and 21 September 2018, Celje, Slovenia

Conference Proceedings

Editors

Polona Vičič

Nataša Gajšt

Alenka Plos 
Title $10^{\text {th }}$ International Language Conference on $»$ The Importance of Learning Professional Foreign Languages for Communication between Cultures«, 20 and 21 September 2018, Celje, Slovenia

Subtitle Conference Proceedings

Editors lect. in English Polona Vičič, PhD

(University of Maribor, Faculty of Logistics)

lect. in English Nataša Gajšt, MA

(University of Maribor, Faculty of Economics and Business)

lect. in German Alenka Plos, MSc

(University of Maribor, Faculty of Economics and Business)

Technical editor

Jan Perša, MEng

(University of Maribor Press)

Cover designer Manca Zrinski

(University of Maribor, Faculty of Logistics)

Logo designer Rafko Počivašek

Conference $10^{\text {th }}$ International Language Conference on »The Importance of Learning Professional Foreign Languages for Communication between Cultures«

Date and location 20 and 21 September 2018, Celje, Slovenia

Programme committee sen. lect. Vesna Cigan, MSc (University of Zagreb, Faculty of Mechanical Engineering and Naval Architecture, Croatia), Denis Cunnigham (FIPLV Honorary Counsellor, Australia), assist. prof. Slavica Čepon, PhD (University of Ljubljana, Faculty of Economics, Slovenia), sen. lect. Dragana Gak, PhD (University of Novi Sad, Faculty of Technical Sciences, Serbia), lect. in English Melita Kukovec, PhD (University of Maribor, Faculty of Arts, Department for English and American Studies, Slovenia), lect. in German Saša Podgoršek, PhD (University of Ljubljana, Faculty of Arts, Department of German, Dutch and Swedish, Slovenia).

Organizing committee assist. prof. Vesna Bogdanović, PhD (University of Novi Sad, Faculty of Technical Sciences, Serbia), lect. in English Nataša Gajšt, MA (University of Maribor, Faculty of Economics and Business, Slovenia), lect. in German Alenka Plos, MSc (University of Maribor, Faculty of Economics and Business, Slovenia), lect. in English Polona Vičič, PhD (University of Maribor, Faculty of Logistics, Slovenia), Manca Zrinski (University of Maribor, Faculty of Logistics, Slovenia).

Co-published by / Izdajatelj

University of Maribor, Faculty of Logistics Mariborska cesta 7, 3000 Celje, Slovenia http://fl.um.si,info.fl@um.si
Published by / Založnik

University of Maribor Press Slomškov trg 15, 2000 Maribor, Slovenia http://press.um.si, zalozba@um.si 


\section{Edition $1^{\text {st }}$}

\section{Publication type E-publication}

Available at http://press.um.si/index.php/ump/catalog/book/399

Published Maribor, March 2019

\section{(C) University of Maribor, University Press}

All rights reserved. No part of this book may be reprinted or reproduced or utilized in any form or by any electronic, mechanical, or other means, now known or hereafter invented, including photocopying and recording, or in any information storage or retrieval system, without permission in writing from the publisher.

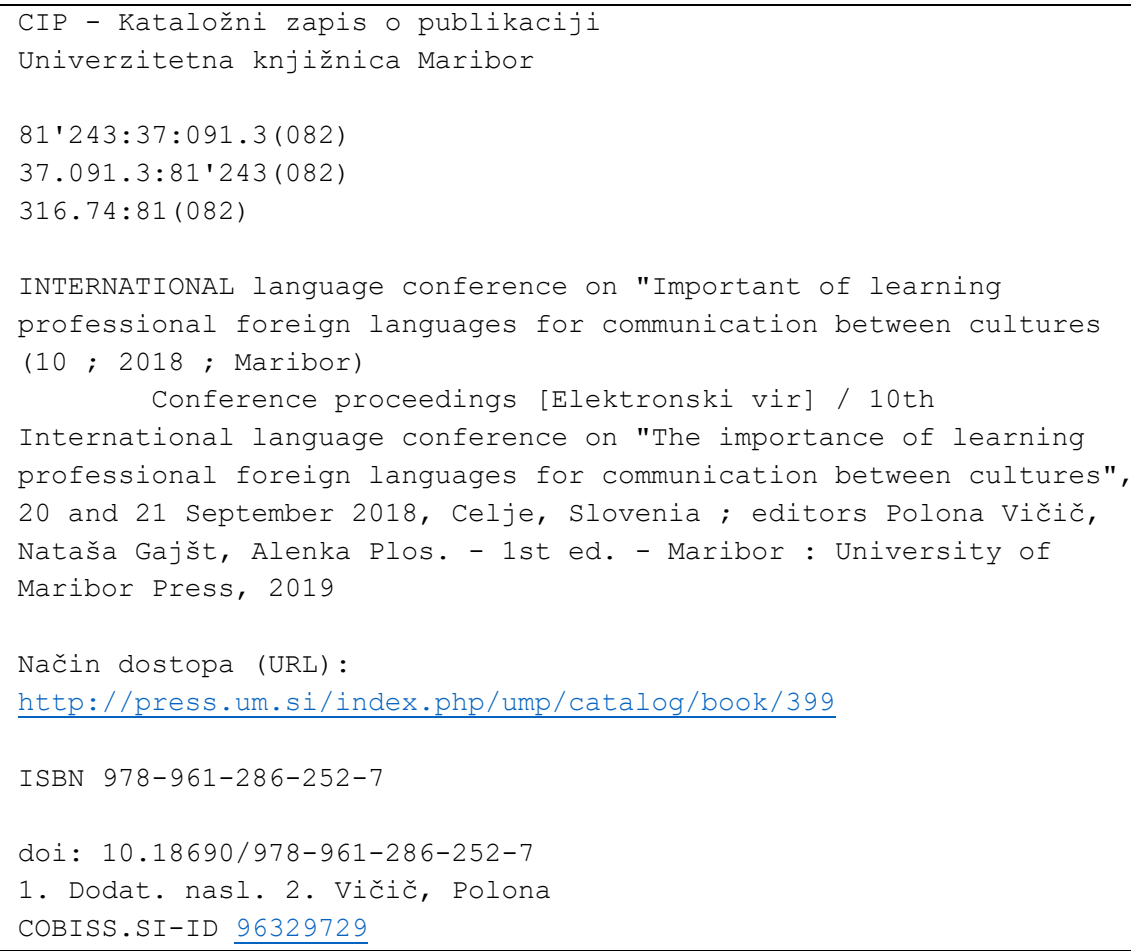

ISBN 978-961-286-252-7 (PDF)

DOI https://doi.org/10.18690/978-961-286-252-7

Price Free copy

For publisher prof. Zdravko Kačič, PhD, Rector (University of Maribor) 



\title{
The Importance of Learning Professional Foreign Languages for Communication between Cultures
}

\author{
Conference Proceedings
}

POlONA ViČIČ, NATAŠA GajŠT \& AlENKa Plos

\begin{abstract}
In today's highly globalised economy speakers of different languages and respective cultures meet and communicate on a daily basis. Hence, it is of paramount importance that formal education at all levels fosters foreign language skills informed by intercultural competence that today's students will need when joining the job market and pursuing their professions. To best cater for the needs of students of different professions, language teaching and learning needs to be adapted to the specific needs of individual professions as well as current and emerging trends in language pedagogy. The exploration and dissemination of relevant expertise and good practice in the field of foreign language pedagogy is the main aim of these proceedings, which include the papers of the $10^{\text {th }}$ International Language Conference on "The Importance of Learning Professional Foreign Languages for Communication between Cultures" held on 20 and 21 September 2018 at the University of Maribor, Faculty of Logistics.
\end{abstract}

Keywords: • professional foreign languages - foreign languages skills - intercultural competence $\cdot$ specific needs of individual professions $\bullet$ current trends in language pedagogy $\bullet$

\footnotetext{
CORRESPONDENCE ADDRESS: Polona Vičič, PhD, Lecturer in English, University of Maribor, Faculty of Logistics, Mariborska cesta 7, 3000 Celje, Slovenia, e-mail: polona.vicic@um.si. Nataša Gajšt, MA, Lecturer in English, University of Maribor, Faculty of Economics and Business, Razlagova 14, 2000 Maribor, Slovenia, e-mail: natasa.gajst@um.si. Alenka Plos, MSc, Lecturer in German, University of Maribor, Faculty of Economics and Business, Razlagova ulica 14, 2000 Maribor, Slovenia, e-mail: alenka.plos@um.si.
} 



\section{Table of Contents}

The Use of English Collocations among Croatian L1 Polytechnic

Students

Katica Balenović \& Slađana Čuljat

Usage of Idioms in Teaching Intercultural Aspects in LSP

Courses

Petra Barbarić \& Ana Matijević

Google Schmoogle: Expect the Unexpected

Mirjana Cibulka \& Maja Mikulec Rogić

Utilisation des médias en classe de langue étrangère

Jasna Ćirić \& Sandra Gvajec

Task-Based Syllabus in Medical English Courses:

A Journey towards Learning Independence

Lorna Dubac Nemet \& Ksenija Benčina

Nursing Case Study in English: Third-Year Written Assignment

Lorna Dubac Nemet \& Ksenija Benčina

Using Learner Corpus Evidence in Error Analysis

Gorana Duplančić Rogošić

Building Croatian Accounting Terminology

Matea Filko, Ana Ostroški Anić \& Ana Ježovita

Die Rolle von Diagnosen im medizinischen

Fachsprachenunterricht: Eine interdisziplinäre Analyse deutscher, österreichischer und ungarischer klinischer Diagnosen

Katalin Fogarasi, Philipp Schneider \& Zoltán Patonai

Business English or Survival English?

Dragana Gak

Die Beschreibung gegenwärtiger Beschwerden in Arztbriefen Analyse deutschsprachiger Formulierungsvorschläge in Musterarztbriefen

Renáta Halász, Zoltán Patonai \& Katalin Fogarasi 
InegMOOC - A MOOC on International Negotiations

Gerhild Janser-Munro \& Tanja Psonder

Factors of Successful Language Acquisition in Students of the

University of Zagreb - Integrative and Instrumental Motivation

Ines Jelovčić, Dubravka Pleše \& Tina Miholjančan

I Cast My Words upon Thee

Luka Jovičić, Nataša Stolić, Danilo Marjanović \&

Mirjana Savić Obradović

Analysis of Student Needs - A Prerequisite in Designing ESP

183

Course Curricula

Ksenija Juretić, Kristina Kaštelan \& Daniela Kružić

Fehler in schriftlichen Texten von Geschichtsstudenten als

Ausgangspunkt für Fehlertherapie im berufsbezogenen

Fremdsprachenunterricht

Brigita Kacjan \& Barbara Žibret

Autonomous AND/OR Dependent: Learning for Success

Iva Lučev

Quest Technologies in Teaching Foreign Languages

Yuliya Lukinykh

The Word Class Noun in English Business Magazines Online

Borislav Marušić \& Sanda Katavić-Čaušić

Self-promotion Rhetoric and (Meta)discourse in Academic

Writing - a Contrastive Study

Nataša Milivojević

Deviation from Established Standards in LSP: Simplification or

Complication?

Olga I. Oparina

Fears and Anxieties of University Students in Learning English for

Professional Purposes

Dubravka Pleše, Tina Miholjančan \& Ines Jelovčić

The Effects of Project Presentation before a Professional

Committee on Student Motivation

Martina Pokupec, Dijana Njerš \& Milan Papić

Hedges and Boosters in University Textbooks

Stanka Radojičić 
Authentic Scientific Articles in ESP Master Courses: Incentives or

Demotivators

Yulia Sizova

Creating an English-Croatian Maritime Dictionary

Tomislav Skračić

Preparing Language Learning Materials for Health Care Students

Elle Sõrmus, Õie Tähtla \& Kateriina Rannula

Inventive Use of Social Media in LSP Course

Neelam Tikkha

Unterscheiden sich slowenische und deutsche Manager

voneinander?

Silvija Tintor

The Writing Skill Needs Analysis in a Professional Context: A

Case Study of Hotel Employees

Dragana Vuković Vojnović \& Jelena Jerković 


\title{
The Use of English Collocations among Croatian L1 Polytechnic Students
}

\author{
KATICA BALENOVIĆ \& SLAĐANA ČULJAT
}

\begin{abstract}
The paper explores the notion of collocations and their most common classification. The primary objective of this paper is to investigate business English collocation usage by Croatian L1 students. The study was conducted among 40 Polytechnic students as a part of an ESP course. The study aimed to examine the productive and receptive knowledge of grammatical and lexical collocations and to gain an insight into Croatian EFL students' collocational competence. A collocation test at both productive and receptive level was taken. Also, the questionnaire consisted personal information and exposure to the English language in a naturalistic setting to question the relationship between participants' language competence and the frequency of exposure to English as well as the participants' collocational knowledge. The research results showed a low level of collocational competence among students, especially on the productive level. Furthermore, the results also showed that there is no relationship among participants' language proficiency, the exposure to English and the participants' collocational competence.
\end{abstract}

Keywords: $\cdot$ competence $\cdot$ collocational competence $\cdot$ Croatian Polytechnic students $\bullet$ productive and receptive knowledge $\bullet$ language transfer $\bullet$

CorReSPONDENCE AdDress: Katica Balenović, PhD, Assistant Professor, University of Zadar, Department of Teacher Education Studies in Gospić, A. Starčević 12, 53000 Gospić, Croatia, email: balenovick@net.com. Slađana Čuljat, Lecturer, Polytechnic "Nikola Tesla” in Gospić, Ban Ivan Karlović 16, 53000 Gospić, Croatia, e-mail: sculjat2012@gmail.com. 


\section{$1 \quad$ Introduction}

The term collocation was first defined by Firth (1957), who is considered as "the father of the collocation". According to his study, collocation is a group of words that occur together, or the way words combine with another word(s). Some authors (e.g. Hill, 2000; Lewis, 2000) describe it as the way in which words cooccur in natural and predictable ways. For example, in the English language, the word "homework" collocates with the verb of "do" rather than with the verb of "write", while in the Croatian language it collocates with the verb "write" as very frequent collocation (do homework/write homework). As seen from the previous example, words are arranged or relate to one another differently in two languages, which might cause a problem for Croatian L1 EFL learners to combine words in English. Most of EFL learners have difficulties in mastering English collocations since it is very difficult for non-native speakers of English to sound in natural, native speaker-like manner in speech or writing. Furthermore, the term "collocation" in its linguistic sense is relatively new, and there is still disagreement, and even confusion about its definition since collocations, idioms and phrasal verbs are sometimes treated as synonyms in the sense of their meaning as a collective whole in a sentence that sounds correct to native speakers.

A broader understanding of collocational relations is found in the works of British contextualism in which collocation is any relation between words that is syntactically and semantically compatible, which makes the notion of collocation comparable to the notion of co-occurrence (Stojić \& Murica, 2012, p. 12). The approach that is mostly applied in lexicography and glotodidactis, based on Firth's theory and identified by Nesselhauf (2005), is the phraseological approach. This approach is applied in research that uses computer analysis of collocations in which they are analysed from the aspects of the frequency of occurrence. That is why this approach Nesselhauf (2005) calls a frequency-based approach.

Hill (1999) introduced the term "collocational competence" as an important segment of SLA since the learners with a low level of this competence make grammatical and lexical errors and create more extended expressions to express themselves, which can lead to misunderstandings. The number of factors has caused the lack of collocational competence among EFL learners, and according 
to some studies (e.g. Chanel, 1981; Ellis, 2001; Nesselhauf, 2003; Durrant \& Schmitt, 2009), the crucial one is negative language transfer or interference from the learner's L1. The influence of the learner's L1 is mainly seen in learning and teaching those collocations that cannot be directly translated from L1 into L2. Because of this, direct teaching of collocation should be an integral part of every language course (Lewis, 2000, p. 8). The present study examines the collocational competence of Polytechnic students attending an ESP course and being taught business collocations as a part of vocabulary learning.

There have been different types of collocations, but the most widely referenced classification (e.g. Benson, Benson \& Ilson, 1997; Hill, 2000; Lewis, 2000) is into two major groups: lexical and grammatical. Lexical collocations are constructions made up of two or more content words (e.g. verb, noun, adjective, adverb) naturally co-occur together in a sentence, as in the following examples:

- Verb + noun (e.g. do homework, make money, have dinner)

- Noun + verb (e.g. crickets chirp, dogs bark, snakes bite)

- Adjective + noun (e.g. heavy traffic, personal computer, compact disc)

- Noun + noun (e.g. bank account, traffic jam, business letter)

- Adverb + adjective (e.g. absolutely fabulous, completely mad, totally upset)

- Verb + adverb (e.g. work hard, sleep tight, sing loudly)

- Verb + expression (e.g. run out of time, come to an end, get into the trouble)

Grammatical collocations refer to word combination that involves content and function of the word, mainly a word (verb, noun, adjective) with a preposition, as in the following examples:

- Verb + preposition (e.g. go on, point out, get through)

- Noun + preposition (e.g. influence on, increase in, report on)

- Adjective + preposition (e.g. loyal to, interested in, responsible for)

- Preposition + noun (e.g. by chance, by heart, on purpose) 


\section{Previous research on L2 English Collocation Acquisition}

L2 learners of English often face difficulties in acquiring collocations since learning collocations as other vocabulary learning is influenced by their mother tongue (Swan, 1997). Negative transfer from the learner's L1 can result in the inappropriate or unpleasant use of vocabulary in the target language. For example, a certain word in learner's L1 may not be used for the same translation equivalent in learner's L2 (e.g. Croatian "gust promet" in English is "beavy traffic", while the adjective-heavy translated into Croatian does not collocate with the word traffic, since in Croatian, the word traffic collocates with the adjective thick and sounds odd and unacceptable in the English language). In other words, the influence of learner's L1 as a cause of interlingual errors in the target language is highly noticeable in the collocation use when collocations in L1 and L2 are noncongruent. There have been numerous studies (e.g. Boonyasaquan, 2006; Koya, 2006; Laufer \& Waldman, 2011; Phoochaorensil, 2011; Malenica \& Mustapić, 2015; Miščin, 2017; Pavičić Takač \& Miščin, 2013) indicated the interference from the learners' L1 (negative L1 transfer) as one of the most common sources of errors, mostly in the usage of lexical collocations on the productive level. For example, Laufer and Waldman (2011) in their study, in which Hebrew learners of English produced collocations, found that half of the unusual collocations seemed to stem from L1 influence. Phoochaorensil (2011) found more errors in the usage of lexical collocations among students than the usage of grammatical ones, especially verb-preposition and preposition-noun collocations.

Furthermore, using L1 transfer is considered the most common learning strategy among students, which resulted in preposition omission or incorrect choice of the same. Another learning strategy as a form of intralingual L2 transfer (Howarth, 1996, 1998) and frequently used by L2 learners is linked with synonyms. According to Biber, Conrad and Reppen (1998) synonyms are typically used in different ways and cannot always be used interchangeably in all contexts. Thornbury (2002) stated that "even the slightest adjustment to the collocations - by substituting one of its components for a near synonym .... turns the text into non-standard English." In other words, despite sharing a similar meaning, the words collocate with other words in a different context with a different meaning. For example, the synonyms powerful and strong can be interchangeable in some collocations (strong/powerful leader), but in some collocations, they cannot be substituted for each other (strong will, but not 
*powerful will). As seen from the previous example, synonymy used as a learning strategy can cause L2 learners to produce erroneous collocations.

Mustapić \& Malenica (2013) and Malenica \& Mustapić (2015) conducted the study on the acquisition of English collocations among the native speaker of Croatian as a part of an LSP course with the aim to analyse the collocation errors in translation tasks as well as to test the correlation between congruence of collocations and the general language proficiency of the learners. The study (Mustapić \& Malenica, 2013) showed that productive tasks pose bigger challenge for language learners than receptive skills as the most previously mentioned studies also showed the same results. Congruent collocations yielded more avoided tasks and resulted in less erroneous tasks. The study also showed that there was no significant difference in the distribution of the main types of errors between higher and lower proficiency learners, but omissions were more notable among the lower proficiency participants (Malenica \& Mustapić, 2015). Higher proficiency learners also have a better understanding of where L1 transfer can be applied with success. Non-congruent collocations are more difficult for language learners to acquire than the corresponding ones since such combinations are not perceived as single units. The authors pointed out a need for didactic improvement regarding new teaching materials that would develop productive knowledge as well as the proper usage of collocations among non-native speakers of English.

Begagic (2014) conducted the study among the students of English language and literature who are native speakers of the Bosnian/Croatian/Serbian (BCS) language. The study examined the productive and receptive knowledge of lexical collocations with the aim to access students' collocational competence. The study showed poor collocational knowledge which the author explains due to the L1 and L2 interference (negative transfer of L1) as well as with the fact that teaching collocations is often neglected.

Miščin (2017) explored the collocational errors of students of Financial Management and found that collocations present a problematic area for the students. She concluded that students' erroneous use of collocations is not the result of their mother tongue interference but lack of their knowledge of financial terms in their mother tongue. 
As seen from previously mentioned studies, most researchers point out that errors in using collocations among EFL learners are the result of language transfer, that is, when EFL learners lack English collocation knowledge, they transfer their L1 knowledge into L2, resulting in awkward and unacceptable word combinations.

\section{The Study Aim and Methodology}

The aim of this research is to gain an insight into Croatian EFL students' collocational competence by examining the productive and receptive knowledge of grammatical and lexical collocations. The research focused on the following three research questions:

1. Do the students recognise more lexical or grammatical collocations?

2. Are the students more successful at the receptive or productive level?

3. Is there a relationship between students' collocation knowledge and frequency of exposure to English in a naturalistic setting?

\subsection{Participants and instruments}

The research involved forty (40) Business English students at the Polytechnic "Nikola Tesla" in Gospić, including 1 $1^{\text {st }}, 2^{\text {nd }}$ and $3^{\text {rd }}-y e a r$ Polytechnic students. The method used to examine the collocational competence of the students was a questionnaire (see Appendix) consisting of three parts. The first part included personal information like age, years of studying the English language, grade in the English language subject in the secondary school, grade in the Business English language during the study, additional English language learning (e.g. an English course). The second part questioned an exposure to the English language in a naturalistic setting, and $3^{\text {rd }}$ part included collocation test at the receptive and productive level involving lexical and grammatical collocations.

The collocation test consisted of two tasks. The first task included a collocation test at the receptive level consisting of 16 sentences, out of which eight sentences are referring to lexical collocations of the following categories: verb + noun, noun + noun and eight sentences relating to grammatical collocations of the following category: verb + preposition - done by multiple choice task type. The second task was a test at the productive level including 16 sentences, out of 
which eight sentences are referring to lexical collocations of the following categories: verb + noun, noun + noun and eight sentences relating to grammatical collocations of the following category: verb + preposition - done by gap filling with the first letter given as a prompt.

The research also looked for on the information about the students' years of studying the English language, which goes from 13 to 14 years, grades in the English language subject in the secondary school and grades during the study. The analysis showed that secondary school marks were greater (good-excellent) than those in their course of study (good), pointing out possible more complex "English" since the students were mainly pupils of the Gymnasium learning general English, while now as the students of the Polytechnic they study Business English, new area in terms of the vocabulary.

All the collocations were taken from the students' course book, all of them being taught during their regular course of study. The students were invited to approach the testing, which was anonymous. The research was carried out in March 2018.

\section{$4 \quad$ Results and Discussion}

The following tables (Table 1 and Table 2) present the students' answers after having completed thirty-two sentences using two task types both at the receptive and productive level, guessing lexical and grammatical collocations. The answers are given in the percentage. Some incorrect answers are also presented in the tables. 
Table 1: Collocation test at the receptive level - lexical and grammatical collocations

\begin{tabular}{|l|c|c|l|}
\hline Target collocation & $\begin{array}{c}\text { Correct answer } \\
\mathbf{( \% )}\end{array}$ & $\begin{array}{c}\text { Incorrect answer } \\
\mathbf{( \% )}\end{array}$ & $\begin{array}{l}\text { Some incorrect } \\
\text { answers }\end{array}$ \\
\hline Make a complaint & $73 \%$ & $27 \%$ & \\
\hline Issue shares & $29 \%$ & $71 \%$ & Make/bring shares \\
\hline Place an order & $65 \%$ & $35 \%$ & \\
\hline Market niche & $13 \%$ & $87 \%$ & Wall/product niche \\
\hline Take responsibility & $63 \%$ & $37 \%$ & $\begin{array}{l}\text { Do/make } \\
\text { responsibility }\end{array}$ \\
\hline Make a suggestion & $60 \%$ & $30 \%$ & \\
\hline Do good & $53 \%$ & $47 \%$ & \\
\hline Make plans & $87 \%$ & $13 \%$ & \\
\hline Go about & $26 \%$ & $74 \%$ & Go across \\
\hline Call of & $37 \%$ & $63 \%$ & Call out/down \\
\hline Point out & $60 \%$ & $40 \%$ & \\
\hline Report to & $44 \%$ & $56 \%$ & Report from/for \\
\hline Benefit from & $39 \%$ & $61 \%$ & Benefit out of/with \\
\hline Depend on & $60 \%$ & $40 \%$ & \\
\hline Responsible for & $80 \%$ & $20 \%$ & \\
\hline Focus on & $49 \%$ & $51 \%$ & Focus at/in \\
\hline
\end{tabular}

Table 2: Collocation test at the productive level - lexical and grammatical collocations

\begin{tabular}{|l|c|c|lr|}
\hline Target collocation & $\begin{array}{c}\text { Correct answer } \\
\mathbf{( \% )}\end{array}$ & $\begin{array}{c}\text { Incorrect } \\
\text { answer (\%) }\end{array}$ & $\begin{array}{l}\text { Some incorrect } \\
\text { answers }\end{array}$ & an \\
\hline Attend an interview & $16 \%$ & $84 \%$ & $\begin{array}{l}\text { Approach } \\
\text { interview }\end{array}$ & \\
\hline Public relations & $87 \%$ & $13 \%$ & & \\
\hline $\begin{array}{l}\text { Communication } \\
\text { skills }\end{array}$ & $55 \%$ & $45 \%$ & & new \\
\hline Recruit a new person & $34 \%$ & $66 \%$ & Receive a & \\
\hline Do research & $76 \%$ & $24 \%$ & & \\
\hline Pay attention & $66 \%$ & $34 \%$ & & \\
\hline Credit card & $76 \%$ & $24 \%$ & & \\
\hline Cash deposit & $40 \%$ & $60 \%$ & & \\
\hline Interest in & $68 \%$ & $32 \%$ & & \\
\hline Satisfaction with & $40 \%$ & $60 \%$ & & \\
\hline Look after & $5 \%$ & $95 \%$ & Look at & \\
\hline Buy up & $5 \%$ & $95 \%$ & & \\
\hline Belong to & $66 \%$ & $34 \%$ & & \\
\hline Insist on & $53 \%$ & $47 \%$ & & \\
\hline Log on & $47 \%$ & $53 \%$ & & \\
\hline Think of & $46 \%$ & $54 \%$ & & \\
\hline & & & & \\
\end{tabular}


Table 1 presents the results of the collocation test at the receptive level referring to lexical and grammatical collocations shown in the percentage. It was a multiple-choice task type. Out of eight lexical collocations, six were answered correctly at quite a high rate (from 53\% to $87 \%$ ) as it can be seen in the table. Most badly guessed collocation refers to "market niche", with the majority of answers given as "wall niche". The result can be explained in a way the students forgot what they had learnt in their course of study and simply were misled by trying to connect the word niche with the Croatian word "niša" - which means a "hollow in the wall" and automatically provided that awkward collocation "wall niche", which in no way could match the sentence given. Out of eight grammatical collocations, only three were answered correctly in a higher percentage (from $60 \%$ to $80 \%$ ). If we compare the results, we can conclude that students showed a better understanding of lexical collocations rather than the grammatical collocations at the receptive level. This conclusion is in a way in contrast with Phoochaorensil's (2011) conclusion, who found more errors in the usage of lexical collocations among his students than the usage of grammatical ones, or studies by Koya, (2006), Miščin (2017) and Malenica and Mustapić (2015), who indicated more errors in the usage of lexical collocations on the productive level.

Table 2 presents the results on the collocation test at the productive level referring to lexical and grammatical collocations shown in the percentage. It was a gap-filling task type with the first letter given as a prompt. Out of eight lexical collocations, five were answered correctly at a high rate (from 55\% to $87 \%$ ).

In terms of "recruit a new person" collocation frequent answer was "receive a new person"; here, again, students were probably misled by their mother tongue and simply translated Croatian word "primiti" into English equivalent "receive", which speaks in favour of a negative language transfer or interference from the students' L1 (Chanel, 1981; Ellis, 2001; Nesselhauf, 2003; Durrant \& Schmitt, 2009). The "attend an interview" collocation was mainly produced as "approach an interview", which also incites L1 influence in producing the right collocation in English, also starting with the first letter "a" which was given as the prompt. Out of eight grammatical collocations, only three were answered correctly in a higher percentage (from 53\% to 68\%). The students showed quite a limited understanding of the "look after" and "buy up" collocations with only $5 \%$ correct answers. Some tries with the "look after" collocation were as follows: look at, 
even look for, existing collocations, but with no matching with the meaning of the sentence given. In a way, this was expected since the mixing of the prepositions with the word "look" were quite usual during the study of the students. If we compare the results, we can conclude that students again showed a better understanding of lexical rather than grammatical collocations at the productive level.

As the answer to the first research question, we conclude that the students better understand lexical collocations $(55.7 \%)$ rather than grammatical collocations $(45.2 \%)$ both at the receptive and productive level (Figure 1).

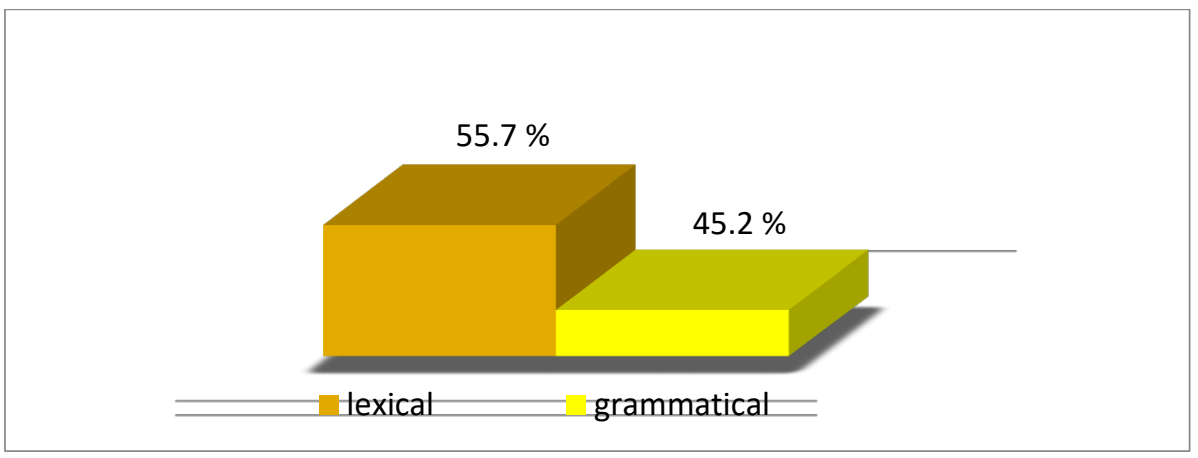

Figure 1: Percentage of the correct use of lexical and grammatical collocations

The answer to the second research question is that the students are better in using collocations at the receptive level with $52.4 \%$ correct answers compared to $48.7 \%$ correct answers at the productive level (Figure 2). This result in a way is not a novelty since many studies (e.g. Mustapić \& Malenica, 2013) carried out by now have shown that non-native speakers regularly show that their English knowledge competence is higher at the receptive level rather than at the productive one. Such finding indicates that when they are offered possible answers, they are more successful in using the right collocation, this might have a connection with the method of "getting an idea", and therefore we cannot speak about true knowledge. 


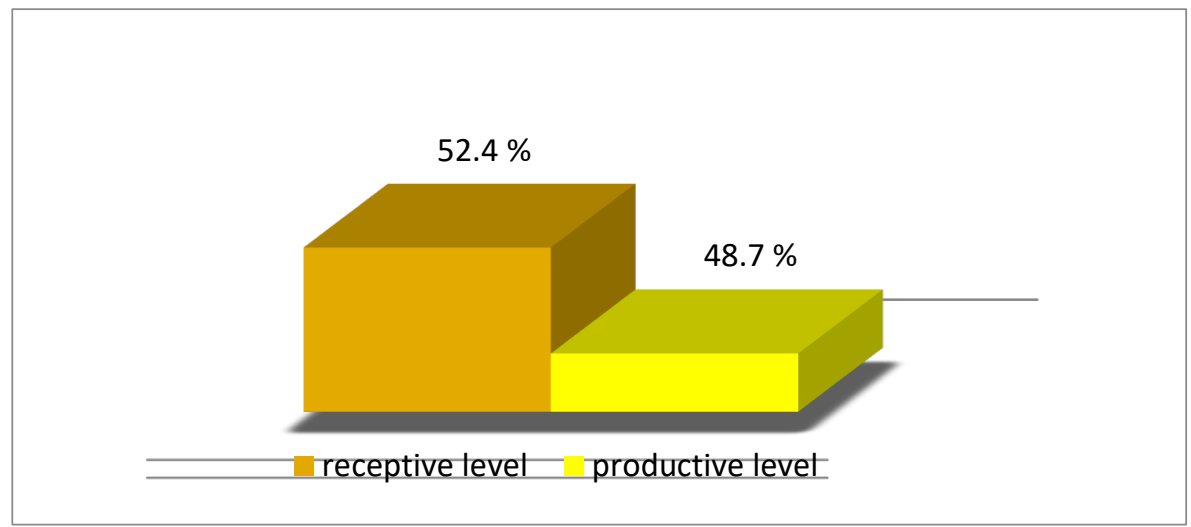

Figure 2: Collocational competence at the receptive and productive level

The following table (Table 3) presents the students' answers showed in percentage referring to five statements describing the frequency of exposure to the English language in a naturalistic setting.

Table 3: Exposure to the English language in a naturalistic setting

\section{STATEMENT}

I use English outside the classroom by reading literature in English I use English outside the classroom by watching movies in English (without subtitles) I use English outside the classroom through writing, sending and receiving e-mails/texting in English

I use English outside the classroom by searching information on the Internet in English I use English outside the classroom by using applications in English

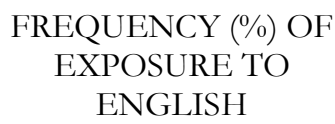

NEVER - RARELY

$85 \%$

$68 \%$

$87 \%$

$13 \%$

$48 \%$

$52 \%$

$40 \%$

$60 \%$
$32 \%$

FREQUENCY (\%) OF

EXPOSURE TO

ENGLISH

OFTEN - VERY

OFTEN

$15 \%$

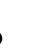


The answer to the third research question based on the students' self-evaluated responses, is that there is no influence on better understanding the collocations regarding the exposure to English in a naturalistic setting. The analysis showed that $52 \%$ of students who for example often - very often use English by searching information on the Internet in English and 60\% students using applications in English showed no better results in corerect use of the collocations.

\section{$5 \quad$ Conclusion}

The study investigated lexical and grammatical collocational errors committed by business English students of the Polytechnic "Nikola Tesla" in Gospić.

The primary objective of the research was to gain an insight into Croatian EFL students' collocational competence by examining the productive and receptive knowledge of grammatical and lexical collocations. Forty Croatian Polytechnic students completed two types of tasks referring to their receptive and productive knowledge. After analysing the research results, we have concluded that students recognise more lexical $(55.7 \%)$ than grammatical (45.2\%) collocations and students are more successful at the receptive $(52.4 \%)$ rather than productive (48.7\%) level in using English collocations. The research also showed that there is no influence of better understanding English collocations among the students who often or very often use English outside the classroom and those who almost never or rarely use English outside the classroom.

In later discussion with the students on the results of the research, their review of such findings is that they still find it difficult in learning and understanding collocations, especially in ESP, Business English here. These results are in line with the previous study conducted by Mišcin (2017) who found out that the students' knowledge of financial terms is poor. The errors made in this research, particularly in using grammatical collocations, are the result of the negative transfer from the learners' L1 since they are still finding connections of the English prepositions with Croatian ones, which regularly lead them to wrong use of English collocations. 
As to conclude we can confirm what previous studies (e.g. Chanel, 1981; Ellis, 2001; Durrant \& Schmitt, 2009; Begagić, 2014) proved and said that unusual and awkward use of collocations is influenced by the language transfer, that is, when EFL learners lack English collocation knowledge they transfer their L1 knowledge into L2. In this particular research, a fact that proves right is that students lack knowledge of business English vocabulary in general. In overcoming these difficulties, it is a teacher's task to devote more time and teaching techniques in fighting these difficulties and helping them to accept collocations as a natural "part" of the English language and devote more time on raising students' awareness on this topic. The method of teaching collocations should also be more systematic with the constant practice of the collocations during ESP classes to improve students' collocational competence as well as communicative competence in general.

\section{References}

Begagić, M. (2014). English language students' productive and receptive knowledge of collocations. De Gruyter, ExELL, 2.1: 46-67. DOI: 10.1515/exell-2016-0003

Benson, M., Benson, E., \& Ilson, R. (1997). The BBI dictionary of English word combinations. Amsterdam: John Benjamins.

Biber, D., Conrad,S., \& Reppen, R. (1998). Corpus linguistics: Investigating language structure and use. Cambridge: Cambridge University Press.

Boonyasaquan, S. (2006). An analysis of collocational violations in translation. Journal of Humanities, 27, 79-91. Bangkok: Faculty of Humanity, Srinakharinwirot University.

Chanel, J. (1981). Applying semantic theory to vocabulary teaching. English Language Teaching Journal, 35, 115-122.

Durrant, P., \& Schmitt, N. (2009). To what extant do native and non-native writer make use of collocations?, IRAL, 17, 157-177.

Ellis, N. C. (2001). Memory for language. In P. Robinson (Ed.), Cognition and second language instructions (pp. 33-68). Cambridge: Cambridge University Press.

Firth, J. R. (1957). Papers in linguistics, 1934-1951. Oxford: Oxford University Press.

Hill, J. (1999). Collocational competence. English Teaching Professional, 11, 3-6.

Hill, J. (2000). Revisiting priorities: From grammatical failure to collocational success. In M. Lewis (Ed.), Teaching collocation: Further development in the lexical approach (pp. 4769). London: Commercial Colour Press Plc.

Howarth, P. (1996). Phraseology in English academic writing. Some implications for language learning and dictionary making. Tübingen: Niemeyer.

Howarth, P. (1998). Phraseology and second language proficiency. Applied Linguistics, 19, 45-72.

Koya, T. (2003). A study of collocation in English and Japanese noun-verb combinations. Intercultural Communication Studies, XII-1, 125-145. 
Lewis, M. (Ed.) (2000). Teaching collocation: Further development in the lexical approach, London: Commercial Colour Press Plc.

Laufer, B., \& Waldman, T. (2011). Verb-noun collocations in second language writing: A corpus analysis of learners' English. Language Learning, 61(2), 647-672.

Malenica, F., \& Mustapić, E. (2015). Acquisition of English collocations through productive skills - Analysis of translation errors. International Journal of English Linguistics, 5(4), 42-49. DOI: 10.5539/ijelv5n4p42

Miščin, E. (2017). Collocational errors of financial management students. In D. Stolac \& A. Vlastelić (Eds.), Jezik kao predmet proučavanja i jezik kao predmet poučavanja. Zagreb: Srednja Europa, HDPL.

Mustapić, E. \& Malenica, F. (2013). Collocations as a part of an English LSP course The importance of congruence for achieving English language proficiency. In P. Vičič, V. M. Ipavec \& A. Plos (Eds.), Proceedings of the $6^{\text {th }}$ International Language Conference on the Importance of Learning Professional Foreign Languages for Communication between Cultures. Celje: University of Maribor.

Nesselhauf, N. (2003). The use of collocations by advanced learners of English and some implications for teaching, Applied Linguistics, 24(2), 223-242.

Nesselhauf, N. (2005). Collocations in a learner corpus. Amsterdam: John Benjamins.

Pavičić Takač, V., \& Miščin, E. (2013). Exploring collocational competence of non-native users of medical English. JAHR, 4(7), 235-256.

Phoocharoensil, S. (2011). Collocational errors in EFL learners' interlanguage. Journal of Education and Practice, 2(3), 103-120.

Stojić, A., \& Murica, S. (2010). Kolokacije - teorijska razmatranja i primjena u praksi na primjerimam iz hrvatskoga i njemačkoga jezika. Fluminensia: časopis za filološka istraživanja, 22(2), 111-125.

Swan, M. (1997). The influence of the mother tongue on second language vocabulary. In N. Schmitt \& M. McCarthy (Eds.), Vocabulary: Description, acquisition and pedagogy (pp. 40-63). Cambridge: Cambridge University Press.

Thornbury, S. (2002). How to teach vocabulary. Edinburgh: Pearson Education Limited, Longman. 


\section{Appendix}

\section{QUESTIONNAIRE}

Please, read carefully and fill out the required information and tasks. The results of this questionnaire will be used exclusively for research purposes of the author. The questionnaire is anonymous.

\section{Part I: PERSONAL INFORMATION}

* Male * Female

Age

Occupation

Years of studying the English language

Grade in the English language subject in the secondary school

Grade in the Business English language during the course of the study

Additional English Language Learning (e.g. a course)

\&ES (specify level of knowledge)

$* \mathrm{NO}$

\section{Part II: EXPOSURE TO THE ENGLISH LANGUAGE IN A NATURALISTIC SETTING}

Circle the letter in front of the correct statement.

$\neg$ I use English outside the classroom by reading literature in English
a) never
b) rarely
c) often
d) very often

$\neg$ I use English outside the classroom by watching movies in English (without subtitles)
a) never
b) rarely
c) often
d) very often

$\neg$ I use English outside the classroom through writing, sending and receiving e-mails / texting in English
a) never
b) rarely
c) often
d) very often

$\neg$ I use English outside the classroom by searching information on the Internet in English
a) never
b) rarely
c) often
d) very often

$\neg$ I use English outside the classroom by using applications in English
a) never
b) rarely
c) often
d) very often 


\section{Part III:}

\section{A) COLLOCATION TEST AT THE RECEPTIVE LEVEL}

Please, fill in the empty space with the word that best collocates with the word in bold to make the sentences complete (only one answer is correct):

1. Have you ever a complaint about the poor quality of something you bought?

- done

- carried

- made

- proposed

2. A company can shares, or units of its capital to the general public.
- buy
- issue
- make
- bring

3. In order to get the item, you first have to an order.
- take
- make
- do
- place

4. Val-Mart clearly wants to establish a particular niche for itself in Europe.
- product
- market
- company
- wall

5. We train our staff to responsibility whatever the situation.

- make

- do

- take

- conduct

6. Have you ever any suggestions about how customer service could be improved in shops that you have visited?
- done
- made
- taken
- thought 
7. Is complaining useful? Do you think it

- does

- makes

- tries

- performs

8. I usually plans for everything I have to do.

- do

- make

- try

- turn out

9. It will be difficult conference to organise. How shall we go it?

- with

- up with

- about

- across

10. The meeting has been called any good? to attend.

- off

- down

- out

- in

11. In her presentation she pointed some of the problems that the new project would involve. because several people are unable
- of
- out
- on
- about

12. In the purchasing department there is a manager and five employees who report her.

- over

- for

- to

- from

13. The Personnel Manager thinks that we would all benefit further training in how to use the office software.

- in

- out of

- from

- with 
14. The amount of responsibility of any individual in a company depends the position that he or she occupies in its hierarchy.
- of
- about
- in
- on

15. Managers are responsible leading people directly under them.

- about

- of

- for

- in

16. The memo usually focuses one message or piece of information, and often requests action to be taken.

- in

- for

- on

- at

\section{B) COLLOCATION TEST AT THE PRODUCTIVE LEVEL}

Please, fill in the empty space with the word that best collocates with the word in bold to make the sentences complete (first letter given).

1. After having sent a CV and a Letter of Application the candidates may be invited to a an interview.

2. $\mathrm{P}$ relations experts specialise in organising activities which generate positive publicity for companies.

3. The successful applicant should be able to use their own initiative and have good c_ skills.

4. When a company wishes to $\mathrm{r}$ a new person for an important position it may use the services of headhunters or executive search firms.

5. Do you prefer to d-------_ research in a library or on the internet?

6. Managers from Sweden $\mathrm{p}$ close attention to the quality of working life.

7. A c card allows you to buy goods and pay for them later.

8. I opened an account with the Medway Bank on 28 January with a cash d of EUR 300.

9. I would like you to show an interest $i$ this very important project for our economy. 
10. She showed no satisfaction w the job proposal by our new partner.

11. The new subsidiary in Bahrain will be looking a our operations in the Middle East.

12. We already own $30 \%$ of the company's shares and we intend to buy u. at least another $20 \%$ in the coming year.

13. Most of our staff belong $t$ at least one of the company's sports or leisure clubs.

14. Pollution, such as smoke in the air, can be reduced if companies use trains instead o. road transport.

15. A new trend is that Europeans $\log \mathrm{O}$ to investment fever more and more.

16. We'll need some more time to think o your proposal before we can give you an answer.

Thank you! 


\title{
Usage of Idioms in Teaching Intercultural Aspects in LSP Courses
}

\author{
Petra BARbarić \& ANA MatijeVić
}

\begin{abstract}
We are going to explore the role idioms have in conveying concepts and displaying cultural elements in English and Spanish academic language courses. Learning figurative language of idioms offers insight into collective consciousness of a particular culture. When students become aware of the span and influence that idioms possess in establishing social conventions and norms, they can improve their communication skills and gain better understanding of a target culture. There are idioms that overlap in meaning across different languages and cultures in spite of their language-specific nature in general. This indicates intercultural dimension of languages that share similar historical and cultural backgrounds and have cross-cultural relations. There are interesting etymological aspects to be observed in idiomatic expressions; many are of native, folk or pagan origins, some come from literature and mythologies while others are coined more recently in reference to different social groups, movements or literary authors.
\end{abstract}

Keywords: $\bullet$ communicative competences $\bullet$ idioms $\bullet$ intercultural dimension $\bullet \mathrm{LSP} \bullet$ social conventions $\bullet$

CORRESPONDENCE ADDRESS: Petra Barbarić, MA, English Language Lecturer, University of Zagreb, Faculty of Humanities and Social Sciences, I. Lučića 3, 10000 Zgreb, Croatia, e-mail: pbarbari@ffzz.hr. Ana Matijević, MA, Spanish language lecturer, University of Zagreb, Faculty of Humanities and Social Sciences, I. Lučića 3, 10000 Zgreb, Croatia, e-mail: amatijev@fffzg.hr. 


\section{$1 \quad$ Introduction}

In teaching foreign languages for academic and specific purposes we often address the importance of close interaction between language and culture and its significance in acquiring more proficient levels of language competences. This relationship has been researched and highlighted in many scientific and academic works. One of the most noticeable traits in language teaching that reflects the cultural aspect is idiomatic expressions. They are defined as fixed or semi-fixed phrases, known as 'figures of speech', different in meaning from the individual words and often difficult to understand, esp. out of context. Idiomatic meanings will, in general, be widely understood within a specific culture. Idioms can be grouped in a variety of ways, e.g. by grammar (verb + object or prepositional phrase), as compounds, similes, conversational phrases, sayings and proverbs. Some are very flexible and others are more fixed.

Traditionally, figurative language such as metaphors and idioms has been considered derivative from and more complex than ostensibly straightforward literal language. A contemporary view, as exemplified not only in psychological but also in linguistic and philosophical research, is that figurative language involves the same kinds of linguistic and pragmatic operations that are used for ordinary, literal language (Glucksberg \& McGlone, 2001).

\section{$2 \quad$ Culture and Idioms}

\section{$2.1 \quad$ Culture}

Culture is a unit of beliefs and practices of a society, it covers customs, religions, arts and social instructions of each individual group or people in a society. Idioms reflect culture and provide access to culture - they are a kind of cultural phenomenon.

There are many ways to define culture; it is often called "the silent language" and "the hidden dimension," because it is mostly consisted of concepts, attitudes, values, ways of interacting with and looking at the world (Furstenberg, Levet, English, \& Maillet, 2001). All the above mentioned makes teaching cultural aspects very demanding and challenging for a teacher. It is not easy to convey something that is elusive, intangible or hidden. That is why we teachers use all 
the means and tools available in order to do this. Teaching idioms through cultural prism can serve as one of these tools and teaching L2 idioms is a communicative activity involved in many distinctive aspects of different culture(s).

Language, culture, and their mutual interactions have prominent significance in teaching and learning a foreign language. Students perceive and explain experiences through the lens of culture. Notions related to culture are revolving around meaning and deriving meaning which makes it similar to notions related to languages and learning L2. Culture expresses meaning through a variety of ways such as literature, arts, rites, ceremonies, mythologies, and folk tales while language expresses meaning through the words and what they signal and signify. There is an obvious link that connects language(s) and culture(s).

\subsection{Purpose of Teaching Idioms}

We teach university students with different 2L knowledge and our aim is to give them understanding of idioms to develop greater awareness of stylistic features. By encouraging contextual guesswork we allow students to express themselves metaphorically and in that way we offer insight into $2 \mathrm{~L}$ culture. Idioms and cultures are closely connected to each other and they often carry hidden meaning connected with the culture at hand. Varieties in language use within a L2 culture create different perspectives in students' perception of that culture. Learning a second culture is often intricately intertwined with learning a second language. Teaching second language should be accompanied with teaching second culture. We as teachers should equip ourselves with the knowledge of second culture, make students familiar with cultural differences and engage them in the exploration of other cultures.

Like other types of figurative language, idioms appear to be the natural decoders of customs, cultural beliefs, social conventions, and norms. Idioms, as a major component of native-like communication, enable a language learner to understand the thoughts, emotions and views of the speakers of L2. For this reason, learning idioms provides learners with a significant chance to acquire information about the underlying parameters of a language. Awareness of figurative language particularly idioms will improve teaching and assist learners to have better communication strategies. Otherwise, accurate and appropriate target language use and understanding will be at risk and the learners will tend to 
transfer their native language conceptual structure which will most probably be inappropriate. The strong relationship among the language, culture, and the figurative branch of the language especially idioms need particular attention in language learning. Today cultures are interacting and mixing more than ever, that is why the way we teach languages is changing and adapting to this melting of cultures. We need to provide students with the skills and knowledge that will enable them to communicate effectively across different cultures. Language teachers are in an excellent position to play an important role in this endeavour since they teach both language and culture. The general focus in a modern L2 classroom should be on the process that enables students to gradually and collaboratively construct and refine their understanding of the other culture both in and outside of class. Making our students interested and engaged in L2 culture greatly facilitates learning process and teaching idioms is one of the notable features in the entire endeavour.

Idioms are extremely present in everyday, authentic usage and thus they function as a part of the culture. Due to this fact, L2 learners are being introduced to different idiomatic expressions as a part of language learning and are expected to master as many L2 idioms as possible if they want to achieve proficiency in a language.

\subsection{Etymology of Some Common English Idioms}

English idioms are a product of English speaking cultures and are strongly influenced by arts, sports, politics, religion, economy and history of different societies that are native speakers of English language. As a particular part of culture, English idioms reflect the characteristic of the nationality. The influence of cultural context on meaning varies from one word to another and from one example to another. Here are some examples that are connected to the cultural contexts.

Throw in the towel/sponge - admit that you cannot do sth comes from the world of sports, namely boxing where this is done by a boxer's trainer to stop the fight. Under the weather - not feeling well finds its roots from the days when ships were powered by sail, this phrase possibly has nautical or seafaring origins. Commenting on the origins of this expression, a website called The Phrase Finder mentions that in the old days, when a sailor was feeling seasick, "he was 
sent down below to help his recovery, under the deck and away from the weather."

Burning the midnight oil - to work late originally by the light of an oil lamp or candle. The English author Francis Quarles wrote in Emblemes, 1635:

Wee spend our mid-day sweat, or mid-night oyle;

Wee tyre the night in thought; the day in toyle.

The phrase 'burning the midnight oil' is still in everyday use.

Long in the tooth - old, esp. of horses or people. Horses's teeth, unlike humans', continue to grow with age. They also wear down with use, but the changes in the characteristics of the teeth over time make it possible to make a rough estimate of a horse's age by examining them. There are various similar Latin phrases dating back to the 16th century. The gap between these and the first citation of the English version - in 1852, make it likely that 'long in the tooth' was coined independently from those earlier Latin sayings. That earliest citation is in Thackeray's, The History of Henry Esmond, Esq. and refers to a woman rather than a horse: "His cousin was now of more than middle age, and had nobody's word but her own for the beauty which she said she once possessed. She was lean, and yellow, and long in the tooth; all the red and white in all the toy-shops in London could not make a beauty of her."

Elvis has left the building -the show has come to an end used to be announced at the end of Elvis Presley's concerts to encourage fans to accept that there would be no further encores and to go home. It is now used more widely to indicate that someone has made an exit or that something is complete. Al Dvorin was the regular stage announcer for Elvis Presley during the 1970s. He picked up the phrase and his version can be heard on several live recordings:

"Ladies and gentlemen, Elvis has left the building. Thank you and goodnight." The Kelsey Grammar sitcom 'Frasier' used a play on the line at the end of each show - "Frasier has left the building."

Straight from the horse's mouth -from the highest authority. In horse racing circles tips on which horse is a likely winner circulate amongst punters. The most 
trusted authorities are considered to be those in closest touch with the recent form of the horse, that is, stable lads, trainers etc. The notional 'from the horse's mouth' is supposed to indicate one step better than even that inner circle, that is, the horse itself.

Wear your heart on your sleeve - display emotions openly. This phrase may derive from the custom at middle ages jousting matches. Knights are said to have worn the colours of the lady they were supporting, in cloths or ribbons tied to their arms. The term doesn't date from that period though and is first recorded in Shakespeare's Othello, 1604. In the play, the treacherous Iago's plan was to feign openness and vulnerability in order to appear faithful:

Iago:

It is sure as you are Roderigo,

Were I the Moor, I would not be Iago:

In following him, I follow but myself;

Heaven is my judge, not I for love and duty,

But seeming so, for my peculiar end:

For when my outward action doth demonstrate

The native act and figure of my heart

In compliment extern, 'tis not long after

But I will wear my heart upon my sleeve

For daws to peck at: I am not what I am.

\subsection{Etymology of Some Common Spanish Idioms}

Spanish language has idioms of its own, and while native Spanish speakers would recognise these easily, those acquiring the language often find it difficult to understand or/and use Spanish idioms fluently. Idiomatic expressions often reveal past traditions and even a culture's sense of humour.

Tirar la casa por la ventana - (literal translation: throw the house out the window). Translation: spare no expense. The origin of the idiom goes back to the end of the 18th and beginning of the 19th centuries when it was traditional in Spain for people who won the lottery to throw their furniture and old possessions out of their windows so as to show off their wealth and indicate that they were about 
to commence a new life of luxury. People living in Spain at that time must have used the expression "literally" to convey roughly the same implications. These might have included the implication that the people who throw their possessions out of their windows are wasting or losing money, that they would need to spend a great deal of money buying new things. This may have led native speakers to start using the expression loosely, to refer to situations in which someone is spending or losing large amounts of money somehow unreasonably.

Pasar la noche en blanco - (spend the night in white) have a sleepless night comes from the times when future knights would need to spend the entire night awake, dressed in white before their initiation into knighthood.

Vérsele el plumero - (one's feathers are visible) know what someone is up to. The origin of the phrase dates back to the time of the Cortes de Cádiz in 1812, in which national militias were recognised and regulated; a force composed of volunteers willing to defend progressive ideals. The National Militia was divided into the infantry, cavalry and artillery corps, each having its own uniform and military cap crowned with a curious and striking plume of feathers. This plume of feathers stood out in the distance, being able to distinguish its bearer.

Tomar el pelo - (take the hair) to make a fool of, pull sb's leg. This expression is often used when people are joking around with each other. If you believe someone is trying to fool you or trick you in a funny way you would say 'Me estás tomando el pelo'. It is similar to the english expression "pulling my/your leg" or “you're joking right?". Etymologically coming from Ancient Roman times where a person's beard was his pride and to pull someone's beard was a great insult.

Meter la pata - put one's foot in it. The most likely explanation is that this idiom is related to the hunting world. In Spanish "pata" are the limbs of the animals. So when an animal is caught in a trap of a hunter, it has made a mistake.

\section{$2.5 \quad$ Idioms across Cultures}

Although languages have different historical and cultural backgrounds, because of the similarity in human thinking and the regular pattern of the development of languages, many idioms may be same or similar in form and meaning in several languages. In those instances, when idioms from L1 and L2 have the same form and meaning, we can use direct translation. 
There are multiple theories on shared etymology of idioms, e.g. they are coming from shared ancestral language or they are loan translations. It is most likely that idioms present in several languages in the same form and meaning are the result of a combination of numerous reasons and a testament to our shared human bond and our need for understanding and connection.

It often happens that various cultures use similar or same idioms; "to live in an ivory tower" can be found in more than 35 languages, "to get on someone's nerves" exists in 57 European languages, "shed crocodile tears" in 45 European languages, Arabic, Swahili, Persian, various Indian languages, Chinese, Mongolian and more. Idiomatic phrase found in many languages "it is all Greek to me" is very spread, although the language may change from Greek to Chinese or Arabic, fundamentally, meaning is the same.

\section{Conclusion}

Teachers should approach their students as intercultural learners, using a comparative, cross-cultural approach in learning. We can achieve this through different teaching/learning strategies, e.g. analysing audio and written materials individually and collaboratively, by detecting similarities \& differences between their $1 \mathrm{~L}$ and $2 \mathrm{~L}$. They should be learning in context, which is both a linguistic and cultural phenomenon. When we consider context of culture, we should remember that that is the most intricate part of context as a whole.

Reportedly, there are over 25,000 idioms in English language and there are around 20,000 idioms in Spanish. It is fascinating how numerous and dispersed idioms are and they certainly add colour and variety to a language. Nevertheless, we should warn our students not to use idiomatic expressions in excess because when overused, the speaker sounds unnatural.

Obviously, there is a great variety of idioms in both English and Spanish and they carry out complex information about their cultures. All dialects of English and Spanish have different groups of idioms and situations where a certain idiom can be used. 
Nowadays, it is interesting to observe the emergence of new idioms through the Internet and mass media that are spreading quickly into the languages, especially English. When understanding L2 idioms, we need to instruct our students, but also take care that we as teachers do the same - that we take culture into full consideration.

\section{References}

Culture in Language Learning (2006). In Online Research Library: Questia. Retrieved September 2, 2018, from https://www.questia.com/library/120075205/culturein-language-learning

Furstenberg, G., Levet, S., English, K., \& Maillet, K. (2001). Giving a voice to the silent language of culture: The cultura project. Language Learning \& Technology, 5(1), 55102. Retrieved from http://llt.msu.edu/vol5num1/furstenberg/default.html

Glucksberg, S., \& McGlone, M. S. (2001). Understanding figurative language: From metaphors to idioms. New York, NY: Oxford University Press.

Learn more about Spanish idioms (2018). In Lingoda: Spanish idioms. Retrieved August 18, 2018, from https://www.lingoda.com/en/spanish/idioms

Levine, J. (2018). Common idioms and phrases: Meanings and origins. Retrieved September 13, 2018, from https://owlcation.com/humanities/CommonIdioms-and-Phrases-Meanings-and-Origins

The Phrase Finder (2018). Retrieved August 16, 2018, from https://www.phrases.org.uk Vranić, G. (2016). Hablar pro los codos, Frases para un español cotidiano. Madrid: Edelsa. 


\title{
Google Schmoogle: Expect the Unexpected
}

\author{
Mirjana Cibulka \& Maja Mikulec Rogić
}

\begin{abstract}
It is no secret that students use Google Translate (GT) when learning foreign languages. They want to find the required information fast, and GT makes it happen. Classroom experience has shown students are pleased with the obtained translation and usually do not correct the mistakes this machine translation tool produces. Notwithstanding, today GT produces more accurate translations, showing it would be useless to discourage its use. It would be better to raise awareness on GT's disadvantages since current technology imposes a new kind of interaction with information, and we should motivate students to take a more critical approach. Contemporary generations grow up with digital media and should master digital competency during their education and through working with digital information sources. This paper investigates the possibilities of using GT in teaching LSP using translations of selected professional vocabulary and terms in English and German.
\end{abstract}

Keywords: • critical approach $\bullet$ Google Translate $\bullet$ LSP $\bullet$ machine translation $\bullet$ translation $\bullet$

CORRESPONDENCE ADDRESS: Mirjana Cibulka, mag.educ.philol. angl., Assistant, Karlovac University of Applied Sciences, Trg J.J. Strossmayera 9, 47000 Karlovac, Croatia, e-mail: mirjana.cibulka@vuka.hr. Maja Mikulec Rogić, mag. educ. philol. germ, lecturer, Karlovac University of Applied Sciences, Trg J.J. Strossmayera 9, 47000 Karlovac, Croatia, e-mail: mmrogic@vuka.hr. 


\section{$1 \quad$ Introduction}

Modern technology, which allows rapid access to information and its processing, significantly influences how people learn as well as changes the attitude and behaviour of those participating in the teaching process. Speed in working with information and reliance on technology are important characteristics of the net generation or digital natives - the generation of students who grew up surrounded by digital media (Prensky, 2001; Tapscott, 2001; Berk, 2009). Experience in teaching languages for specific purposes reveals a tendency in using machine translation tools of those students who want to take a short-cut to the desired translation. The use of dictionaries is becoming poorer and less popular (Engelberg \& Lemnitzer, 2009). On the other hand, machine translation tools are fast, free and always available; therefore, it is probable that in future students will rely on these services more often. Furthermore, fast development and progress in this area of technology will intensify this trend.

Among machine translation services available online, Google Translate (GT) is the one that particularly stands out. Since its start it has been registering intense progress and an increase in the number of its users (Turovsky, 2016). GT is free and easily available online. Moreover, it has recently become available even offline for 59 languages (Cattiau, 2018). At the end of 2016, GT transferred to the neural network-based system, and compared with the translations of the past, this system shows considerable improvement in translation accuracy from/to popular foreign languages the system included in the beginning (Wu et al., 2016). Although the improvements are noticeable, this still does not mean each translation is accurate and reliable. This especially concerns lesser-used languages, including Croatian.

However, the problem related to using GT in learning a foreign language and which we want to highlight relates mainly to the students' non-critical approach to inaccurate translations or the fact they accept them without a detailed analysis which proved to be the case in working with students/learners of languages for specific purposes. Werthmann and Witt (2014) state that the users of machine translations tools often tend to ignore inaccurate and unreliable translations since fast and free translation is still better than nothing in a situation where professional translation is not an alternative. Furthermore, it should be stressed that for the students learning a language for specific purposes this is not their 
primary interest and they often use machine translation tools, to gain insight into the theme of the text or to understand the text better.

Since new technologies are now an integral part of everyday life, attention should be brought to their use where digital competence, which focuses mainly on critical approach to information, is one of the key competencies for lifelong learning (Preporuka europskog parlamenta i savjeta; Ključne kompetencije za cjeloživno učenje - Europski referentni okvir, 2010). In this sense, disadvantages and advantages of machine translation tools in teaching languages for specific purposes should be highlighted, and students should be motivated to analyse easily available and free translations. Is there any space for GT and similar translation tools in teaching languages for specific purposes? The answer should be a positive one since this translation tool is already used by LSP students, and it is the teachers' task to evaluate the possibility of using these tools and (if necessary) include them in class activities. Williams (2006) states that motivating students to analyse web-based machine translations or understand the machine translation tool, could trigger the use of other tools, e.g. online dictionaries.

Students' approach to machine translating is superficial and their expectations of GT are unrealistic since GT should not be compared to a professional translation. Additionally, the students' poor knowledge of foreign language and their native language hinders the translation process.

The goal of this paper is not to emphasise the advantages of machine translation tools or to advocate their use, but rather to divert attention to the obvious development in this area and the need to examine these tools the students will undoubtedly use in their future work environment.

\section{$2 \quad$ Machine Translation}

Machine translation is the automatic translation from one natural language into another using computers (Lopez, 2008), and it is in close relation to the development of computational linguistics and artificial intelligence (Mitrović, Božić Lenard \& Galić, 2018). The popularity of machine translation and the demand for translation is increasing even though the results are not satisfying enough, especially in the case of less used languages (Mitrović, Božić Lenard \& Galić, 2018). 
As Werthmann and Witt (2014) highlight, the quality of a machine translation depends on a series of factors, e.g. complexity of the language itself, exceptions, specific meanings as well as lexical and structural ambiguity. Moreover, machine translation tools do not possess the knowledge of the world as humans do, but which is an inevitable part of communication. It is necessary that users are aware of the limitations of such tools and understand that translating is a complex process in which these tools can be a mere support, and they cannot substitute human translation in certain cases.

With the currently popular GT, the internet also offers other machine translation services, e.g. Bing Translator and Yandex Translate. Mitrović, Božić Lenard \& Galić (2018) assessed the work of these three machine translation tools, analysing translations from English to Croatian, and GT yielded the best results. The authors state that, considering the quality of the translations, number and types of errors, GT is the most suitable machine translation tool with constant maintenance and data base updating. Of course, they also highlight that the tools are more usable when considered as additional help rather than an exclusive translation tool, and interventions are required. For their analysis, the authors selected an original scientific article, a popular scientific article and a newspaper article. They concluded that the original scientific article resulted in fewest mistakes and translation issues. The reason behind this result is probably the formal general English language and exact scientific writing style with fewer phrasal verbs, collocations and idiomatic expressions (Mitrović, Božić Lenard \& Galić, 2018).

To highlight the changes in the field of machine translating, we selected the example Werthmann and Witt (2014) mention in their paper on machine translating where they stress the problem of separable prefixes in the German language that go to the end of the sentence, making it difficult for the machine to translate the sentence. The authors state the following example and the related GT translation:

\section{Ein Bäcker stebt gewöhnlich schon um 2:30 Ubr auf.}

GT: A baker is usually already on at 2:30 clock.

Improved translations offered by GT today (Google prevoditelj, 2018):

A baker usually gets up at 2:30. 
A baker usually gets up as early as 2:30.

The authors also give an example with inserted relative clause. Besides the inserted clause, a problem occurs with the gender of the noun Mädchen which does not correspond to its natural gender.

Das Mädchen, das auf seine Mutter wartet, spielt mit seinem Hamster.

GT: The girl who waits for his mother, playing with his hamster.

Translation offered by GT today (Google prevoditelj, 2018):

Girl waiting for his mother plays with his hamster.

These examples show that translations have changed and improved over the years, but certain limitations still exist. GT still does not recognise the discrepancy between grammatical and natural gender of the noun Mädchen, and the pronoun seine is translated (grammatically) correct as his even though the person is of feminine gender, and it should translate the pronoun seine as her.

There is another tool which shows the field of machine translation is developing rapidly. It is called DeepL and it developed from Linguee translation tool. DeepL Translator currently offers translation from/to seven languages: English, German, French, Italian, Dutch, Spanish and Polish (DeepL Translator, 2018). The comments on DeepL are extremely positive with stress on fluency, more natural translation which is easier to read and does not give the impression of a machine processed translation (Pakalski, 2017). Compared with GT, which was also praised after transferring to the neural network system, DeepL yielded better results in a test in which professional translators selected the best translations of over 100 sentences translated by GT, Facebook, Microsoft and DeepL translation tools (Figure 1). 


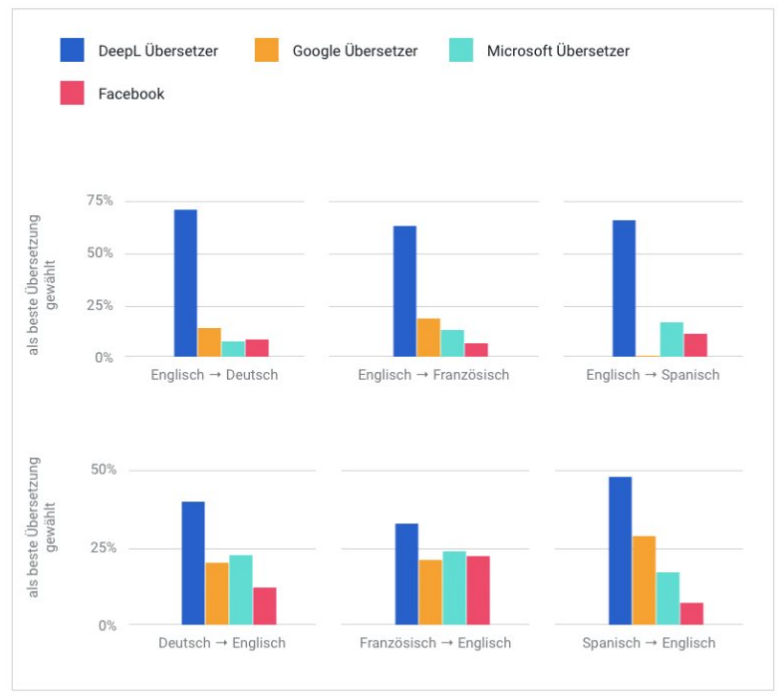

Figure 1: Blind test results with 100 sentences, photo:

https://www.onmsft.com/news/microsoft-translator-is-world-class-fast-butsupercomputer-deepl-translator-wins-out

Furthermore, to prove the intense progress in machine translating, DeepL (DeepL Translator, 2018) translates the above mentioned sentence as:

The girl waiting for her mother is playing with her hamster.

Considering the early start of machine translating, inaccurate and peculiar translations on the one side, as well as GT improvements and DeepL on the other side, we must ask ourselves what we can expect from machine translating in the future.

\section{Google Translate}

Google Translate is a free online service which was established in 2006. Since then, the number of languages has increased from two to 103, and the number of users has increased to over 500 million; 3.5 million users have joined its Translate Community, which improved GT's activities with its 90 million translations (Turovsky, 2016), and the number of words translated on daily basis totals 143 billion (Wolverton, 2018). Furthermore, GT also offers mobile phone applications: instant camera translation (translation from/to 38 languages using 
smartphone camera), conversation mode (speech translation from/to 32 languages) as well as writing language symbols in 93 languages instead of using a keyboard (Google Translate - Apps on Google Play, 2018). Also, GT can be used offline for 59 languages (Cattiau, 2018).

Over the years GT has become a source of poor, unreliable and even ridiculous translations. However, in 2016 GT transferred to a new translation system and presented Google's Neural Machine Translation system. Compared with the previous phrase-based production system, the new system reduced the number of errors by $60 \%$ for several popular language pairs the system initially encompassed (Wu et al., 2016). The new system does not translate only parts of the sentence. It actually considers the entire sentence and its context. The Google team also highlighted additional progress in the development of GT, that is, zero shot translation - translation between language pairs the system has not been exposed to before (Johnson et al., 2017).

GT's development and progress is definitely visible, but judging by personal experience and user comments we find on the internet, this service remains imperfect and cannot substitute a translator/human translation. Notwithstanding, if we consider the fact that smartphones and computers have become inseparable parts of our lives - tools which provide us help in performing various tasks - the progress of machine translating, in this case GT, motivates us to ask ourselves is it realistic to expect that interest in this service will not grow and the students will not use it. Therefore, working with online translation services as well as analysing their advantages and disadvantages are one of the activities we cannot avoid in a foreign language class.

\section{$4 \quad$ Google Translate and language for specific purposes - translation examples}

The goal of analysing translations produced by GT was to examine its benefits for the purposes of learning a language for specific purposes and creating classroom activities where students could employ critical approach to the translation GT offers, and finally to inform the students about the possibilities of using other online tools and content, e.g. online dictionaries.

The reason for analysing this machine translation tool was an assignment given to a group of students who translated a text from English to Croatian using only 
the internet. The results showed that the majority of the students relied mainly on GT and did not correct the offered translation even though the translation was incorrect.

\subsection{Methodology}

Fifteen terms related to the field of fire protection were randomly selected for analysis. GT translated them from English to Croatian and vice-versa, from German to Croatian and vice-versa and from English to German and vice-versa (Google prevoditelj, 2018). Moreover, two shorter texts were also translated by GT, from English to Croatian.

Terms and two shorter texts were selected as the basis of our analysis since students have a tendency to use GT when translating texts since it helps them understand the theme better. The analysis of the offered translations provided answers to the following research questions:

- What should we consider when using GT?

- What information does GT offer its users?

\subsection{Results}

The terms selected for translating were simpler words of the general language (e.g. vatrogasac/firefighter), professional terms from the field of fire protection (e.g. saponification/saponifikacija, grease fire/požari biljnih i životinjskih ulja i masti) and phrasal verbs (Table 1). Out of a total of 15 terms, GT provided 13 accurate translations from English to Croatian. It should also be highlighted that GT offers alternative translations together with the first offered translation which can be accurate or inaccurate. In the case of translating the phrase extinguishing blanket, the first translation was incorrect, but the additional one was accurate. Terms grease fire and metal fire were translated incorrectly. The users who are also familiar with the field of fire prevention could figure out the right meaning, despite the incorrect translations. Notwithstanding, these users might find the term clear enough and they would not even have the need to use GT. Translating these terms to the Croatian language is complex (back translation: fires of oils, fat of animal origin, fires of combustible metals). In these cases, GT does provide 
correct translations and the user should be familiar with the field. The results of the translations are listed in Table 1.

Table 1: Translations from English to Croatian

\begin{tabular}{|c|c|c|}
\hline Source term & GT translation & $\begin{array}{l}\text { GT's additional } \\
\text { translation }\end{array}$ \\
\hline $\begin{array}{l}\text { fire fighter } \\
\text { fire extinguisher } \\
\text { fire protection } \\
\text { ember } \\
\text { extinguishing blanket } \\
\text { grease fire } \\
\text { metal fire } \\
\text { saponification } \\
\text { fireproof } \\
\text { flammable } \\
\text { set on fire } \\
\text { break out } \\
\text { spread fire } \\
\text { catch fire } \\
\text { put out the fire }\end{array}$ & $\begin{array}{l}\text { vatrogasac } \\
\text { aparat za gašenje požara } \\
\text { zaštita od požara } \\
\text { žeravica } \\
\text { ugasiti deku } \\
\text { zapaliti mast } \\
\text { metalna vatra } \\
\text { saponifikacija } \\
\text { otporan na vatru } \\
\text { zapaljiv } \\
\text { Zapaliti } \\
\text { izbiti } \\
\text { širenje vatre } \\
\text { zapaliti se } \\
\text { ugasite vatru }\end{array}$ & $\begin{array}{l}\text { vatrogasaca } \\
\text { Vatrogasni Aparat } \\
\text { zaštita od vatre } \\
\text { deka za gašenje } \\
\text { mast od požara } \\
\text { metalni požar } \\
\text { saponifikacije, } \\
\text { je saponifikacija, } \\
\text { saponifikacijom, } \\
\text { saponifikacijski } \\
\text { vatrootpornih, } \\
\text { vatrootpornog, } \\
\text { nezapaljiv, } \\
\text { vatrootporne } \\
\text { zapaljiva, lako } \\
\text { zapaljivo, } \\
\text { lako zapaljiva,su } \\
\text { zapaljivi } \\
\text { zapaljena } \\
\\
\text { širenje požara } \\
\text { uhvatiti vatru } \\
\text { ugasiti vatru }\end{array}$ \\
\hline
\end{tabular}

In some cases, when synonyms are not offered or do not exist, GT offers that same word as additional translation into Croatian but in different cases, e.g. saponification. Literal translations are also present, e. g. to catch fire. The first offered translation is correct, but the additional one is not since the translation is literal (back translation: get fire, catch fire as a ball). Since the infinitive of the verb set is the same as participle, GT translated the Croatian version both as infinitive and past participle.

Capital and lower-case letters can also influence translation. Actually, if we translate only one word, capital and lower-case letters will not influence the 
translation, but with complex terms, capital and lower-case letters can actually change the translation (Table 2). This is important to highlight since these types of mistakes can occur when copying a text from a document to GT. It should be noted that this problem does not happen with common terms in the general language, that is, word combinations which GT already offers correct translations for.

Table 2: Translations from English to Croatian - capital, lower case

\begin{tabular}{|c|c|c|}
\hline Source term & Translation & $\begin{array}{l}\text { Additional } \\
\text { translation }\end{array}$ \\
\hline $\begin{array}{l}\text { extinguishing blanket } \\
\text { Extinguishing blanket } \\
\text { Extinguishing Blanket } \\
\text { extinguishing Blanket }\end{array}$ & $\begin{array}{l}\text { ugasiti deku } \\
\text { Izbacivanje pokrivača } \\
\text { Ugasivanje posude } \\
\text { za gašenje požara }\end{array}$ & $\begin{array}{l}\text { deka za gašenje } \\
\text { gašenje deka } \\
\text { gašenje Deka } \\
\text { Deka za gašenje }\end{array}$ \\
\hline $\begin{array}{l}\text { break out } \\
\text { Break out } \\
\text { Break Out } \\
\text { break Out }\end{array}$ & $\begin{array}{l}\text { izbiti } \\
\text { Izadi } \\
\text { Izbriši } \\
\text { Izbiti } \\
\end{array}$ & $\begin{array}{l}- \\
\text { izbiti } \\
\text { izbiti } \\
-\end{array}$ \\
\hline $\begin{array}{l}\text { grease fire } \\
\text { Grease fire } \\
\text { Grease Fire } \\
\text { grease Fire }\end{array}$ & $\begin{array}{l}\text { zapaliti mast } \\
\text { Grease požar } \\
\text { Grease Fire } \\
\text { Grease Fire }\end{array}$ & $\begin{array}{l}\text { mast od požara } \\
\text { mast od požara } \\
\text { mast od požara } \\
\text { mast od požara }\end{array}$ \\
\hline
\end{tabular}

As listed in Table 3, singular and plural can also influence the translation, especially in the case of professional language terminology. In this case not a single translation is correct. In the case of simpler words of the general language (e.g. house, pencil, table), changes from singular to plural and vice versa will not affect the translation and the number of the noun will be recognised and translated correctly.

Table 3: Translations from English to Croatian - singular and plural

\begin{tabular}{|l|l|}
\hline Singular & Plural \\
\hline $\begin{array}{l}\text { grease fire - zapaliti mast } \\
\text { metal fire - metalna vatra }\end{array}$ & grease fires - smrznuti požari \\
metal fires - metalnih požara \\
\hline
\end{tabular}

Another element which can change the translation is article (the or a). Table 4 includes examples of sentences where the word fire is used with and without article. 
Table 4: Translations from English to Croatian - articles the, a

\begin{tabular}{|l|l|l|}
\hline Source sentence & GT translation & $\begin{array}{l}\text { Additional GT } \\
\text { translation }\end{array}$ \\
\hline $\begin{array}{l}\text { Fire broke out. } \\
\text { The fire broke out. } \\
\text { A fire broke out. }\end{array}$ & $\begin{array}{l}\text { Provalio je vatru. } \\
\text { Vatra je izbila. }\end{array}$ & $\begin{array}{l}\text { Izbio požar. } \\
\text { Požar je izbio. }\end{array}$ \\
Provalio je vatru. & Požar je izbio. \\
\hline
\end{tabular}

With translations from English, GT lists additional information next to the source word. For example, the word fire is accompanied with the definitions of the word (for noun and verb), sentence examples or terms with specific meanings, synonyms, sentence examples in which this word is used, and other words which could be in relation to the source word. The translation contains other meanings of the translated word and synonyms.

It should be highlighted that the majority of the definitions and the relating examples of the word fire is equal to those provided by Oxford's Online Dictionary (Oxford Dictionaries: English Dictionary, Thesaurus, \& grammar help, 2018). Furthermore, additional information is provided for individual words. For example, we will not have additional information for the entire term extinguishing blanket, but they will be listed for individual words extinguish/ing and blanket.

By listing this data, GT actually connects the online translation service with online dictionary which is practical for potential users. However, based on the experience of working with students, GT is a tool for translating, not for researching additional information of the word. If the students would learn more about GT, the way it functions and the information it offers, they would (probably) become aware of its benefits and flaws; they would develop a more critical approach, and more importantly, they would focus on using online dictionaries.

Translations from Croatian to English in Table 5 show correct examples. However, terms požari biljnih $i$ životinjskih ulja $i$ masti (back translation: fires of animal and vegetable oils and fats) as well as požari zapaljivih metala (back translation: combustible metal fires) were translated descriptively, which is in any case better than the translation from English into Croatian. Considering the description is clearer than the shorter term in English, it is much easier to translate it. 
Table 5: Translations from Croatian to English

\begin{tabular}{|c|c|c|}
\hline Source term & GT translation & $\begin{array}{l}\text { Additional GT } \\
\text { translation }\end{array}$ \\
\hline $\begin{array}{l}\text { vatrogasac } \\
\text { aparat za gašenje požara } \\
\text { zaštita od požara } \\
\text { žeravica } \\
\text { deka za gašenje požara } \\
\text { požari bilinih i } \\
\text { životinjskih } \\
\text { ulja i masti } \\
\text { požari zapaliivih metala } \\
\text { saponifikacija }\end{array}$ & $\begin{array}{l}\text { firefighter } \\
\text { fire extinguisher } \\
\text { fire protection } \\
\text { ember } \\
\text { for fire extinguishing } \\
\text { fires of plant and animal } \\
\text { oils } \\
\text { and fats } \\
\text { flames of flammable } \\
\text { metals } \\
\text { saponification }\end{array}$ & $\begin{array}{l}\text { blanket, fire } \\
\text { extinguisher } \\
\text { fires vegetable and } \\
\text { animal oils and fats } \\
\text { combustible metal } \\
\text { fires } \\
\text { the saponification, } \\
\text { saponification of, } \\
\text { a saponification of, } \\
\text { a saponification } \\
\text { fireproof, flame } \\
\text { retardant } \\
\text { inflammable, } \\
\text { incendiary, } \\
\text { priming } \\
\text { light } \\
\text { break out } \\
\text { spread of fire } \\
\text { catch fire } \\
\text { extinguish the fire }\end{array}$ \\
\hline
\end{tabular}

Compared with English/Croatian and Croatian/English combinations, the translations from German to Croatian and from Croatian to German are less accurate. In the case of German/Croatian combination (Table 6) the following words were not translated accurately: Feuerschuts, Glut, Löschdecke, Fettbrand, Metallbrand, Brandausbreitung, and the term Feuer löschen was translated in imperative and not infinitive. The first offered translation of the term in Brand geraten was translated in past tense ( $3^{\text {rd }}$ person singular) instead in the infinitive, but the additional translation of the same term was translated in infinitive. It is interesting that additional translations also include words in English (Glut - glow, ausbrechen - break out). One of the offered translations for the word Glut is glow, which corresponds to one of the meaning, but it does not match the context. 
Furthermore, English phrasal verb break out was offered as additional translation of the word ausbrechen.

Additional translations offered by GT appear on the screen by clicking on the translated word or term. Incorrect translation of the words Löschdecke, Fettbrand and Metallbrand consists of two words which GT does not present as one single term and it is necessary to click on each word for additional translations, but yet again this action will not result in accurate translation. GT obviously recognises parts of the German compound word and translates the words individually.

Table 6: Translations from German to Croatian

\begin{tabular}{|c|c|c|}
\hline Source term & GT translation & Additional GT translation \\
\hline $\begin{array}{l}\text { Feuerwehrmann } \\
\text { Feuerlöscher } \\
\text { Feuerschutz } \\
\text { Glut } \\
\text { Löschdecke } \\
\text { Fettbrand } \\
\text { Metallbrand } \\
\text { Verseifung }\end{array}$ & $\begin{array}{l}\text { vatrogasac } \\
\text { aparat za gašenje } \\
\text { požara } \\
\text { vatra } \\
\text { sjaj } \\
\text { vatra Deka } \\
\text { mast od požara } \\
\text { metalni požar } \\
\text { saponifikacija }\end{array}$ & $\begin{array}{l}\text { vatrogasaca, Vatrogasci, } \\
\text { vatrogasca } \\
\text { aparat, Aparat za gašenje u, } \\
\text { Aparat } \\
\text { za gašenje, aparati } \\
\text { požar, od požara, požara, } \\
\text { gašenje } \\
\text { gorjeti, sijati, glow, plamtjeti }\end{array}$ \\
\hline $\begin{array}{l}\text { feuerfest } \\
\text { brennbar } \\
\text { in Brand setzen } \\
\text { ausbrechen } \\
\text { Brandausbreitung } \\
\text { der Brand breitet sich } \\
\text { aus } \\
\text { das Feuer breitet sich } \\
\text { aus } \\
\text { sich ausbreiten } \\
\text { in Brand geraten }\end{array}$ & $\begin{array}{l}\text { otporan na vatru } \\
\text { zapaljiv } \\
\text { zapaliti } \\
\text { izbiti } \\
\text { vatra proširila } \\
\text { vatra se širi } \\
\text { vatra se širi } \\
\text { raširena } \\
\text { zapalio je } \\
\text { Ugasite vatru }\end{array}$ & $\begin{array}{l}\text { saponifikacije, } \\
\text { saponifikacija, } \\
\text { saponifikacijom, } \\
\text { saponifikacijski } \\
\text { vatrootpornih, } \\
\text { vatrootpornog, } \\
\text { nezapaljiv, vatrootporne } \\
\text { zapaljiva, lako zapaljivo, lako } \\
\text { zapaljiva, su zapaljivi } \\
\text { zapaljena } \\
\text { izbiti iz, buknuti, break out, } \\
\text { izbijati }\end{array}$ \\
\hline & & $\begin{array}{l}\text { širenje } \\
\text { zapaliti se } \\
\text { požara }\end{array}$ \\
\hline
\end{tabular}


In some cases, capital and lower-case letters have considerable influence on a translation. As a result, GT translates words Fenerschutz and Löschdecke correctly if they are written in lower-case letters (Table 7) which is wrong since nouns are written in capital letters in German.

Table 7: Translations from German to Croatian - capital and lower case

\begin{tabular}{|l|l|}
\hline Source term & GT translation \\
\hline Feuerschutz & vatra \\
feuerschutz & zaštita od požara \\
Löschdecke & vatra Deka \\
löschdecke & deka za gašenje \\
Feuer löschen & Ugasite vatru \\
feuer löschen & ugasiti vatru \\
\hline
\end{tabular}

As in the case of translating from Croatian to English, the terms fires of vegetable and animal fats and oils are translated descriptively in German (Table 8). The word zapaliti (set on fire) is incorrectly translated, and the verb in the term ugasiti požar is translated as ausschalten (German) or turn off (English). However, additional translations offer the correct verb both for German and English. Additional translations also contain words which are not only in the nominative case, but in others too (e.g. feuerfest, feuerfeste; brennbare, brennbaren). 
Table 8: Translations from Croatian to German

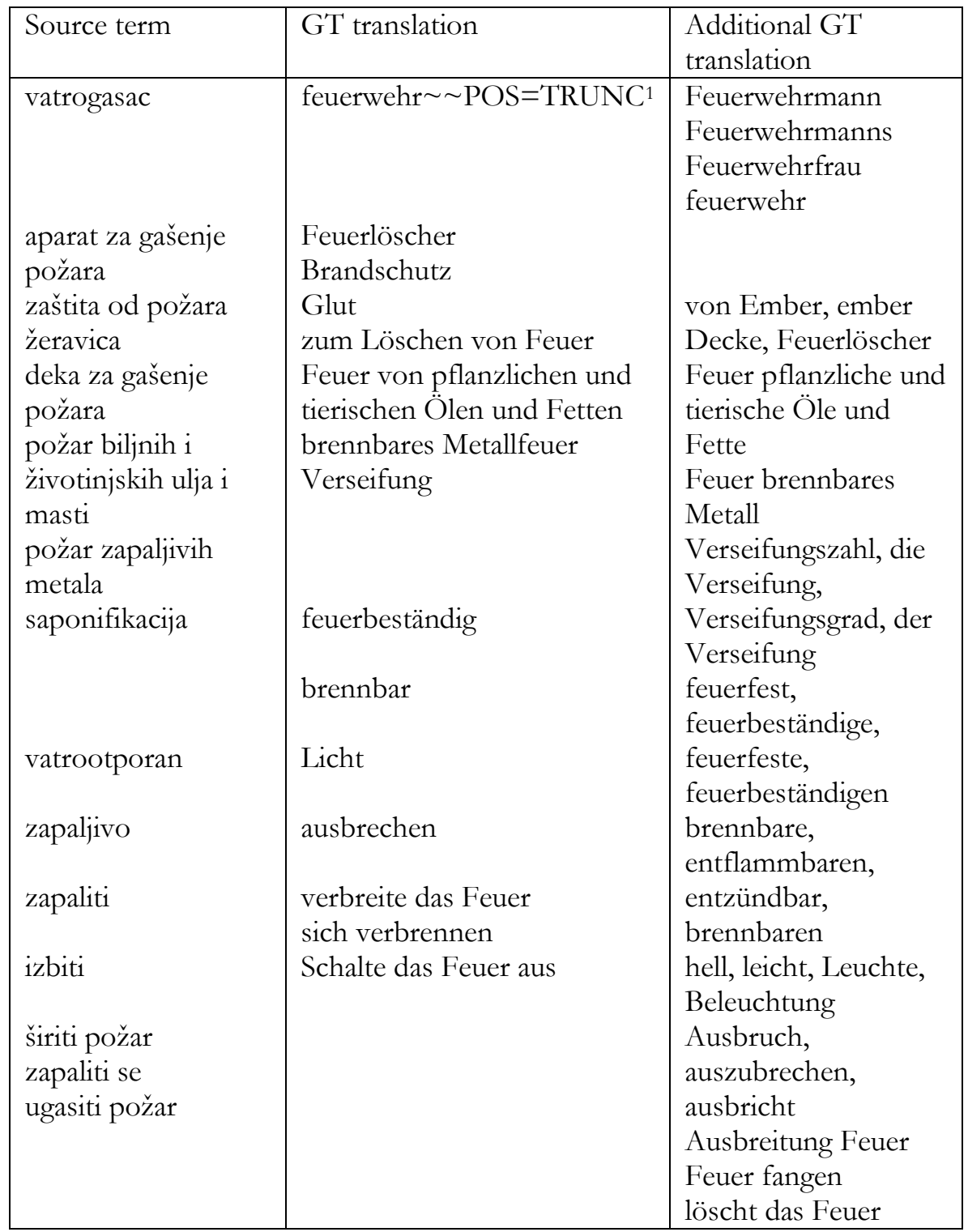

Translations from English to German are accurate, and they are offered as first or additional translation (Table 9). Terms grease fire and metal fire, incorrectly translated from/to Croatian, are translated accurately here (Fettbrand, Metallbrand) since the terms are similar and both consist of two words of the same meaning, 
unlike the Croatian term which is translated descriptively and consists of more words. As mentioned before, infinitive and participle of the verb set are the same, but the German translation offers only the past participle version. The terms put out the fire is not translated in the infinitive. It is translated in imperative and preterite.

Table 9: Translations from English to German

\begin{tabular}{|c|c|c|}
\hline Source term & GT translation & $\begin{array}{l}\text { Additional GT } \\
\text { translation }\end{array}$ \\
\hline $\begin{array}{l}\text { fire fighter } \\
\text { fire extinguisher } \\
\text { fire protection } \\
\text { ember } \\
\text { extinguishing blanket } \\
\text { grease fire } \\
\text { metal fire } \\
\text { saponification } \\
\text { fireproof } \\
\text { flammable } \\
\text { set on fire } \\
\text { break out } \\
\text { spread fire } \\
\text { catch fire } \\
\text { put out the fire }\end{array}$ & $\begin{array}{l}\text { Feuerwehrmann } \\
\text { Feuerlöscher } \\
\text { Brandschutz } \\
\text { Glut } \\
\text { Löschdecke } \\
\text { fetten Feuer } \\
\text { Metallfeuer } \\
\text { Verseifung } \\
\text { feuerfest } \\
\text { brennbar } \\
\text { angezündet } \\
\text { ausbrechen } \\
\text { verbreite das Feuer } \\
\text { Feuer fangen } \\
\text { lösch das Feuer }\end{array}$ & $\begin{array}{l}\text { in Brand gesetzt, in } \\
\text { Brand } \\
\text { gesteckt } \\
\text { Ausbreitung Feuer } \\
\text { sich entzünden } \\
\text { lösche das Feuer, } \\
\text { löschte } \\
\text { das Feuer }\end{array}$ \\
\hline
\end{tabular}

As described in Table 10, capital and lower case affect the translation also in this case. 
Table 10: Translations from English to German - capital and lower case

\begin{tabular}{|l|l|l|}
\hline Source term & GT translation & $\begin{array}{l}\text { Additional GT } \\
\text { translation }\end{array}$ \\
\hline grease fire & fetten Feuer & Fettbrand \\
Grease fire & Feuer fetten & \\
Grease Fire & Fett Feuer & \\
grease Fire & Fett Feuer & Verteilt Feuer \\
Spread fire & Verbreite das Feuer & Spread Feuer \\
Spread Fire & Verbreite Feuer & \multicolumn{2}{|l}{} \\
\hline
\end{tabular}

There are not any significant irregularities in German to English translations, but the use of capital and lower case should be definitely highlighted. The word Löschdecke is translated into English as Fire Blanket, but written in lower case (löschdecke), the same word is translated as extinguishing blanket, and GT does not treat it as a one term and it is required to click on each word individually to obtain additional translations. The examples of other translations are listed in Table 11. 
Table 11: Translations from German to English

\begin{tabular}{|c|c|c|}
\hline Source term & GT translation & $\begin{array}{l}\text { Additional } \quad \text { GT } \\
\text { translation }\end{array}$ \\
\hline $\begin{array}{l}\text { Feuerwehrmann } \\
\text { Feuerlöscher } \\
\text { Feuerschutz } \\
\text { Glut } \\
\text { Löschdecke } \\
\text { Fettbrand } \\
\text { Metallbrand } \\
\text { Verseifung } \\
\text { feuerfest } \\
\text { brennbar } \\
\text { in Brand setzen } \\
\text { ausbrechen } \\
\text { sich ausbreiten } \\
\text { Brandausbreitung } \\
\\
\text { der Brand breitet sich aus } \\
\text { in Brand geraten } \\
\text { ein Feuer löschen }\end{array}$ & $\begin{array}{l}\text { firefighter } \\
\text { extinguisher } \\
\text { Fire protection } \\
\text { glow } \\
\text { Fire Blanket } \\
\text { grease fire } \\
\text { metal fire } \\
\text { saponification } \\
\text { fireproof } \\
\text { flammable } \\
\text { set on fire } \\
\text { breaking out } \\
\text { to spread } \\
\text { fire spread } \\
\\
\text { the fire spreads } \\
\text { on fire } \\
\text { put out a fire }\end{array}$ & $\begin{array}{l}\text { fireman, the fighter, } \\
\text { fire } \\
\text { fighter } \\
\text { firefighter fireman } \\
\text { fire extinguisher } \\
\text { embers, heat, ardor, } \\
\text { ember } \\
\text { dousing blanket, } \\
\text { extinguisher blanket } \\
\text { oil \& fat fire } \\
\text { hydrolysis (of) } \\
\text { refractory, fire resistant } \\
\text { inflammable, } \\
\text { combustible } \\
\text { set fire to } \\
\text { breaking free, break } \\
\text { out spread, spread out } \\
\text { fire spreading, fire } \\
\text { from spreading, fire growth, } \\
\text { slame spread, fire } \\
\text { spreads } \\
\text { caught fire, catch fire } \\
\text { to extinguish a fire, out } \\
\text { a } \\
\text { fire }\end{array}$ \\
\hline
\end{tabular}

Definite and indefinite article also influence the translation as shown in Table 12. 
Table 12: Translations from German to English - articles

\begin{tabular}{|l|l|l|}
\hline Source term & GT translation & $\begin{array}{l}\text { Additional GT } \\
\text { translation }\end{array}$ \\
\hline $\begin{array}{l}\text { Feuer löschen } \\
\text { ein Feuer löschen }\end{array}$ & $\begin{array}{l}\text { Extinguish fire } \\
\text { put out a fire }\end{array}$ & $\begin{array}{l}\text { out fires } \\
\text { to extinguish the fire, } \\
\text { out a } \\
\text { fire } \\
\text { to extinguish the fire, } \\
\text { dastinguish the fire }\end{array}$ \\
\hline
\end{tabular}

In addition to the mentioned terms we also analysed two shorter texts relating to trends in hand protection and clutter in working environments. Detailed analysis revealed that the sentences which did not contain professional terminology were translated mainly correctly. However, the issues of incorrect cases still appeared and GT confused infinitive with imperative. Furthermore, GT also had problems with translating headlines since they were ambiguous. GT also had difficulty with recognising the context so it failed to translate the word plant as tvornica (back translation: factory). It actually translated the word plant as bijkea (back translation: living organism). Despite the issues mentioned above, students use GT for translating texts since it helps them gain better insight into the text's context/theme. Notwithstanding, they should understand that GT is merely a support tool and it is useless without background (professional and language) knowledge, especially when they are translating from English to Croatian.

\section{$5 \quad$ Conclusion}

Analysis of translations processed by GT machine translation tool shows improvements in translating compared with the translations the tool had offered in the past. However, it still has limitations and difficulties regarding professional language vocabulary as well as translating language pairs in both directions.

GT can offer one translation or several depending on the word, term, sentence or text, that is, depending on the frequency of their use and belonging to a specific field or theme. Translations of professional terms from English to German showed that capital and lower case as well as singular/plural and definite/indefinite article can influence the accuracy of translation which means the user can influence the translation when entering a word or text. 
The problems of machine translating, mentioned previously in the paper (Werthmann \& Witt, 2014), still occur, despite the improvements of the tool itself. These problems mainly relate to multi-meaning, exceptions to grammar rules, similarities and differences in languages. Translations from German to English and vice-versa show fewer irregularities than translations from/to Croatian. This can be explained with similarities, that is, differences between the languages, and the fact these languages are popular.

Furthermore, when translating from English, in addition to translations, GT also offers additional information - definitions of words, sentence examples, synonyms and it also refers to other words which could be related to the source word. The majority of definitions and examples we came across are equal to those offered by the Oxford Online Dictionary. Although GT is primarily a machine translation tool to its users, detailed analysis of its work and referencing to the mentioned additional information could motivate the use of online dictionaries.

Translations of texts can help us gain better insight into the theme of the text, but GT is not good enough when it comes to translating professional language terminology since that requires background knowledge of the profession and language. Analysis of translated texts revealed problems with ambiguous terminology, but strictly professional terms, especially those of the same root (e.g. Latin) were translated accurately.

GT is not an ideal tool for translating and providing assistance in learning a foreign language. However, it should not be ignored in this context simply because it is part of the technology used every day and it changes rapidly to suit users' needs. Therefore, the problems relating to machine translating should be highlighted through classroom activities in the hope that students will stop using this or other tools superficially and in their search for information or translation might actually return to the start-point - the language itself.

\section{References}

Berk, R. A. (2009). Teaching strategies for the net generation. Transformative Dialogues: Teacbing \& Learning Journal, 3(2), 1-24. Retrieved from https://www.researchgate.net/publication/228346567_Teaching_strategies_for _the_net_generation 
Blind test results with 100 sentences [Digital image]. (2017). Retrieved from https://www.onmsft.com/news/microsoft-translator-is-world-class-fast-butsupercomputer-deepl-translator-wins-out

Cattiau, J. (2018, June 12). Offline translations are now a lot better thanks to on-device AI. Retrieved from Google Blog: https://www.blog.google/products/translate/offline-translations-are-now-lotbetter-thanks-device-ai/

DeepL Translator. (2018). Retrieved from https://www.deepl.com/translator

Engelberg, S., \& Lemnitzer, L. (2009). Lexikographie und Wörterbuchbenutzung. Tübingen: Stauffenburg Verlag.

Google prevoditelj. (2018). Retrieved from https://translate.google.hr/?hl=hr

Google Translate - Apps on Google Play. (2018). Retrieved from https://play.google.com/store/apps/details?id=com.google.android.apps.transl ate\&hl=en

Johnson, M., Schuster, M., Le, Q. V., Krikun, M., Wu, Y., Chen, Z., \& ... Dean, J. (2017). Google's multilingual neural machine translation system: Enabling zero-shot translation. Retrieved from https://arxiv.org/abs/1611.04558v2

Lopez, A. (2008). Statistical machine translation. ACM Computing Surveys, 40(3), 40,1-49.

Mitrović, D., Božić Lenard, D., \& Galić, I. (2018). Održavanje baza alata za strojno prevođenje. In H. Glavaš, T. Barić, E. K. Nyarko, T. Keser, M. Karakašić, \& M. Barukčić (Eds.), 27. Medunarodni znanstveno-stručni skup „Organizacija i tehnologija odř̌avanja" - OTO 2018. - Zbornik radova (pp. 23-32). Osijek: Fakultet elektrotehnike, računarstva i informacijskih tehnologija Osijek. Retrieved from https://www.bib.irb.hr/934634

Oxford Dictionaries: English Dictionary, Thesaurus, \& grammar help. (2018). Retrieved from https:/ / en.oxforddictionaries.com/

Pakalski, I. (2017, August 29). DeepL im Hands on: Nenes Tool übersetzt viel besser als Google und Microsoft. Retrieved from golem.de: https://www.golem.de/news/deepl-imhands-on-neues-tool-uebersetzt-viel-besser-als-google-und-microsoft-1708129715.html

Prensky, M. (2001). Digital natives, digital immigrants. On the Horizon, 9(5), 1-6. Retrieved from

http://www.marcprensky.com/writing/Prensky\%20\%20Digital\%20Natives, $\% 2$ 0Digital\% 20Immigrants\%20-\%20Part1.pdf

Preporuka europskog parlamenta i savjeta; Ključne kompetencije za cjeloživno učenje Europski referentni okvir. (2010). Metodika: časopis za teoriju i praksu metodikâ u predskeolskom odgoju, školskoj i visokoškolskoj izobrazbi, 11(20), 169-182. Retrieved from http://hrcak.srce.hr/61536

Tapscott, D. (2011). Odrasti digitalno: kako mrežna generacija mijenja naš svijet. Zagreb: Mate d.o.o. i Zagrebačka škola ekonomije i managementa.

Turovsky, B. (2016, April 28). Ten years of Google Translate. Retrieved from Google Blog: https://www.blog.google/products/translate/ten-years-of-google-translate/

Werthmann, A., \& Witt, A. (2014). Maschinelle Übersetzung - Gegenwart und Perspektiven. In G. Stickel (Ed.), Translation and Interpretation in Europe. Contributions to the Annual Conference 2013 of EFNIL in Vilnius (pp. 79-103). Frankfurt am Main/Berlin/Bern/Bruxelles/New York/Oxford/Wien: Lang. Retrieved from https://ids-pub.bszbw.de/frontdoor/deliver/index/docId/4487/file/Werthmann_Witt_Maschinell e_Uebersetzung_Gegenwart_und_Perspektiven_2014.pdf 
Williams, L. (2006). Web-based machine translation as a tool for promoting electronic literacy and language awareness. Foreign Language Annals, 39(4), 565-578. Retrieved from

http://web.pdx.edu/ fischerw/courses/advanced/methods_docs/pdf_doc/w bf_collection/0251_0300/0295_FLA_2006_Williams.pdf

Wolverton, T. (2018, July 23). Google CEO Sundar Pichai revealed a jaw-dropping fact about its translation app that shows how much money is still sitting on the table. Bussines Insider. Retrieved from https://www.businessinsider.com/

Wu, Y., Schuster, M., Chen, Z., Le, Q. V., Norouzi, M., Macherey, W., \& ... Dean, J. (2016). Google's neural machine translation system: Bridging the gap between human and machine translation. Retrieved from https://arxiv.org/abs/1609.08144v2 


\title{
Utilisation des médias en classe de langue étrangère
}

\author{
JASNA ĆIRIĆ \& SANDRA GVAJEC
}

\begin{abstract}
Abstrait Résumé Cet article parle de l'integration des documents issus des médias dans l'enseignement de la langue française. Les médias sont des documents authentiques qui exposent les apprenants à la réalité sonore de la langue cible qui est authentique, vivante, naturelle. Ils mettent les apprenants en contact direct avec la vie socioculturelle d la langue qu'ils apprennent. La fonction de ces documents c'est qu'ils facilitent l'entrée dans un thème, expliquent, enseignent, informent, motivent. Du fait que ces documents ne sont pas conçus à des fins didactiques, ils représentent un défi pour l'enseignant qui les rend didactiques par leur exploitation en tenant compte des objectifs d'acquisition des connaissances linguistiques mais aussi interculturelles. L'élément culturel est inévitable dans l'apprentissage de la langue. La contextualisation aide à comprendre un document, mais aussi la réalité sociale, historique, culturelle du pays concerné. Grâce à ces documents, l'enseignement devient plus moderne, dynamique et intéractif et les apprenants plus actifs.
\end{abstract}

Mots-clés: • document authentique • enseignement du FLE • fins didactiques - connaissances linguistiques et interculturelles • média •

\footnotetext{
ADRESSE DE CORRESPONDANCE: Jasna Ćirić, professeur de français et italien, Université de Zagreb, Faculté de Lettres, Centre des langues étrangères, Ulica Ivana Lučića 3, 10000 Zagreb, La croatie, e-mail: jciric@ ffzg.hr. Sandra Gvajec, professeur de français et tchèque, Université de Zagreb, Faculté de Lettres, Centre des langues étrangères, Ulica Ivana Lučića 3, 10000 Zagreb, La croatie, e-mail:sandra.gvajec@ gmail.com.
} 


\section{$1 \quad$ L'introduction}

L'intégration des documents issus des médias dans l'enseignement des langues étrangères est devenue une priorité, un besoin. Elle rend l'enseignement plus dynamique, plus interactif, les apprenants deviennent les participants actifs dans l'apprentissage. Le manuel n'est plus que l'un des supports de l'enseignement même s'il a gardé son utilité considérable. La fonction de ces documents est qu'ils facilitent l'entrée dans un thème, expliquent, enseignent, informent, motivent, distraient, déclenchent la parole.

L'intégration de ces documents est très facile grâce à l'accessibilité à de nombreuses sources d'informations.

L'utilisation des médias et de nouvelles technologies motive les apprenants, ils les aiment et ils s'en servent dans leur vie quotidienne. La motivation joue un rôle important dans l'apprentissage.

\section{$2 \quad$ Les médias}

Les médias sont des documents authentiques qui exposent les apprenants à la sonorité de la langue qui est authentique, vivante, naturelle dans son contexte social et culturel ce qui n'est pas souvent présent dans l'enseignement traditionnel de langue, marqué par des situations, conversations simulées et stéréotypées. L'utilisation de ces documents constitue une communication réelle. Ils mettent les apprenants en contact direct avec la vie socioculturelle dont la langue ils apprennent. Ces documents ne sont pas conçus à des fins pédagogiques, mais ils peuvent devenir authentiques par l'exploitation que fait l'enseignant (Tagliante, 2006). Il faut les décoder, analyser et en comprendre sa signification.

L'accessibilité à ces documents facilite la variation des supports et des contenus proposés aux apprenants tout en tenant compte de leur personnalité, âge, intérêt, de leur niveau de connaissance de langue, mais aussi, bien sûr, des objectifs d'acquisitions de connaissances linguistiques et interculturelles.

Les médias et les nouvelles technologies représentent un support très important dans l'enseignement des langues étrangères qui facilitent la réussite du processus d'apprentissage. 
Il est important de dire que l'intégration des médias dans l'enseignement représente un défi aussi pour les enseignants qui doivent être au courant de nouvelles technologies et apprendre à se servir de nouveaux outils pour pouvoir les appliquer dans leur travail pédagogique. L'enseignant garde son rôle important dans le processus d'apprentissage. C'est lui qui choisit et gère les documents supplémentaires dans la multitude de documents, d'informations accessibles, c'est lui qui crée un cours pédagogique avec des objectifs d'apprentissage. L'information n'est pas le savoir. Il faut savoir s'en servir. Les possibilités d'exploitation pédagogique sont nombreuses. L'efficacité de l'utilisation de ces documents dépend de la façon dont ils sont utilisés, de la complexité de la tâche qu'on demande des apprenants. Ce qui est commun pour tous les médias utilisés dans l'apprentissage de langue est que l'on peut les faire entrer dès les niveaux les plus bas. A des niveaux bas de la connaissance on travaillera sur le vocabulaire et des connaissances grammaticales, ainsi que sur l'oralité pendant qu'à des niveaux avancés on pourra approfondir le travail avec l'analyse thématique, dimensions interculturelles.

Concernant le côté ludique des documents authentiques il faut dire qu'aucun document authentique ne doit pas être utilisé seulement pour le simple divertissement. Le but d'enseignement est beaucoup plus complexe. Un document authentique doit avoir une relation à la leçon donnée, il doit la compléter. Le thème de ce document doit être intéressant et actuel. Ce qui importe encore, c'est la longueur du document qui doit être adaptée au niveau de connaissance de langue.

L'utilisation des documents issus des médias a pour objectifs tant que le développement des connaissances linguistiques - compréhension orale et écrite et production orale et écrite - aussi bien les compétences sociolinguistiques et socioculturelles. L'élément culturel est inévitable dans l'apprentissage de la langue. La contextualisation aide à comprendre un document, mais aussi la réalité sociale, culturelle, artistique du pays concerné. 
Les médias utilisés en la classe de langue étrangère sont :

La presse écrite

La radio

La télévision

Le film

L'internet

\subsection{La presse écrite}

La presse écrite est une source de nombreuses informations et sa fonction est d'informer, d'éduquer et distraire les gens et il faut dire que ces fonctions ne sont pas exclusives l'une de l'autre. La presse avec ses documents authentiques peut contribuer au développement de la capacité lexicale et sémantique des apprenants en les familiarisant avec le nouveau vocabulaire ou simplement pour réviser le lexique déjà acquis. Si l'objectif de l'enseignement est la production écrite, la presse offre un éventail d'opportunités pour réviser ou introduire les phénomènes grammaticaux, comme par exemple l'utilisation des exercices de réparation de texte ou les textes lacunaires. Aussi, pour développer la production orale dès les niveaux les plus faibles la simple lecture d'un article permet d'exercer la prononciation, l'accent.

La presse contribue au développement de toutes les quatre compétences, mais aussi des compétences interculturelles car la langue fait partie intégrale de la culture et apprendre une langue étrangère signifie aussi entrer en contact avec la culture du pays cible. Le rôle d'enseignant est très important car il doit encourager ses apprenants à prendre conscience de la diversité. La presse écrite est aussi importante pour la formation de l'esprit critique des apprenants. Grâce à de nombreuses nouvelles traitées par les journaux, la presse peut aussi provoquer le débat public, la confrontation des opinions. Les apprenants prennent position par rapport à certains thèmes. Ils expriment et défendent leurs opinions (Cipra \& Hermelin,1982). Aussi certains thèmes peuvent servir de comparaison dans les deux cultures, celle de l'apprenant et celle du pays étranger. 


\subsection{La télévision}

Quant aux chaines de télévision et aux lignes de radio, l'approche de l'exploitation de contenu a changé. Le développement de nouvelles technologies nous a permis de suivre des programmes pas seulement de la manière traditionnelle, mais aussi sur l'ordinateur, la tablette numérique ou son portable (Smartphone). Aussi il y a des programmes offerts par TV5MONDE qui offre un grand nombre d'émissions faites à des fins didactiques, servant à l'apprentissage du français.

\section{$2.3 \quad$ La radio}

Aujourd'hui la radio est peut-être le document authentique le moins utilisé dans la classe de langue étrangère. Il lui manque l'image qui facilite la compréhension. Les apprenants sont habitués à l'accessibilité à des documents visuels. Malgré cela, les possibilités d'exploitation sont considérables. La radio ne s'écoute plus seulement en direct, on peut télécharger ses émissions et les écouter dépendant des besoins de la classe. Avec une émission radio l'enseignant peut travailler toutes les quatre compétences surtout la compréhension orale.

\section{$2.4 \quad$ L'internet}

Les nouvelles technologies nous ont ouvert une nouvelle manière d'enseigner une langue étrangère. L'internet n'est pas seulement un outil mais il est devenu un fort partenaire dans l'enseignement en générale. L'Internet est une source de documents riches et actuels (écrits, sonores, audiovisuels) qui ne sont pas faits comme matériel pédagogique mais qui peut y servir. L'utilisation d'internet d'une manière didactique exige un énorme travail de l'enseignant, car il faut réfléchir comment intégrer un matériel choisi dans l'enseignement, déterminer précisément les objectifs didactiques pour en tirer le plus grand profit et enfin susciter le désir d'apprendre chez les apprenants.

La sélection des documents pris d'internet dépendra des objectifs d'apprentissage, mais aussi du niveau de connaissance de langue et de l'intérêt des apprenants. L'exploitation de ces documents doit être bien guidée. Sur l'internet on peut trouver des documents servant à la compréhension orale et écrite et production orale et écrite et aussi des documents servant d'exercices de prononciation, grammaire, lexique. La plupart de ces documents a une composante culturelle, inséparable de l'apprentissage de langue. Sur l'internet 
nous pouvons trouver les différents sites qui offrent les possibilités illimitées pour enrichir l'apprentissage d'une langue. En s'en servant les apprenants sont immergés dans la langue authentique, dans la situation réelle ce qui leur permet de sortir de l'enseignement traditionnel et de se lancer dans une nouvelle aventure d'apprentissage qui les motive et amuse.

\subsection{Le film}

L'utilisation du film dans l'enseignement du français représente un facteur très motivant. C'est un document authentique préféré des apprenants. Il leur est très proche et accessible. Grâce à ce fait les apprenants apprendront plus facilement les structures grammaticales, lexicales, mais aussi la culture. Apprendre une langue n'est pas seulement apprendre le lexique et la grammaire, mais aussi la culture, le mode de vie, les mœurs, les valeurs. Avec le film on élargit l'horizon, au va plus loin dans l'apprentissage et la compréhension générale.

L'important est que les objectifs d'enseignement soient clairs et bien déterminés (Tagliante,2006). En choisissant un film, l'enseignant doit tenir compte du fait que le film parle du thème qui se fait dans la classe, de l'intérêt des apprenants et de la composition de la classe. Par conséquent il faut incorporer le visionnage du film dans l'enseignement en tenant compte des objectifs d'apprentissage. Bien sûr il ne faut pas oublier le rôle ludique du film, un facteur très motivant.

Le choix du film dépendra aussi du niveau de la connaissance de langue des apprenants. Quant à ce critère, l'enseignant peut introduire le visionnage de certaines séquences du film, choisies avec des objectifs bien déterminés. De cette manière même les apprenants d'une faible connaissance de langue pourront venir en contact avec la langue authentique, mais aussi avec la culture et les mœurs du pays dont la langue ils apprennent.

Quant aux apprenants dont la connaissance de langue est plus élevée, eux, ils pourront voir le film complet.

Les objectifs d'enseignement doivent être clairs et bien déterminés quelle que soit leur connaissance de langue.

Avant le visionnage du film, l'enseignant doit sensibiliser les apprenants pour le thème du film en faisant quelques activités concernant le film. A travers les 
affiches ou bandes annonces, on fait connaître le titre du film, le réalisateur, le genre du film, les acteurs, mais aussi les personnages, les lieux, les époques. Dans cette première étape on peut même lire le contenu ou la critique du film ce qui peut faciliter le suivi du film. Dans cette étape l'accent est mis sur le vocabulaire concernant le film.

Dans la deuxième étape suit le visionnage du film. Il est important pour cette étape, que l'enseignant donne aux apprenants les activités qui ne gêneront pas le suivi du film. Les activités qui peuvent être proposées dans cette étape sont : le suivi de l'action du film, d'un certain événement, les personnages principaux, les éléments culturels, les faits historiques, la musique. Le choix des activités dépendra aussi du choix du film présent dans la classe.

Dans la troisième étape, après avoir fait les activités de la deuxième étape, on propose de faire l'analyse du film. L'accent est mis d'un côté, sur l'utilisation du vocabulaire et des structures concernant le film, mais aussi le but est d'encourager des apprenants à la réflexion critique et créative. Le développement de la réflexion critique et créative et l'un des objectifs le plus important de l'enseignement en général, ainsi que de l'enseignement des langues étrangères. L'utilisation du film dans la classe de FLE est facilitée par la présence de plusieurs fiches pédagogiques déjà préparées sur Internet. On peut les utiliser telles qu'elles le sont ou les adapter à la classe.

Quel que soit le document authentique utilisé, toutes ces activités qu'on fait dans la classe ont plusieurs points communs :

- analyse du genre médiatique du document exploité

- compréhension du sens général du document (questions générales)

- compréhension précise du document (questions détaillées)

- travail sur la langue: préparation du travail de production en travaillant sur les structures langagières

- production orale et écrite - la synthèse du document

- réflexion critique et créative 


\section{Conclusion}

L'utilisation des documents issus des médias est un avantage positif. Il contribue à l'acquisition et au développement des compétences linguistiques mais aussi interculturelles. Grâce au fait qu'il est un facteur motivant dans l'apprentissage, il éveille chez les apprenants le désir d'apprendre, la curiosité vers d'autres cultures, mais aussi développe leur intérêt pour les différents thèmes. L'utilisation des médias permet à l'enseignant de sortir de l'enseignement traditionnel et d'appliquer les nouvelles technologies ce qui représente un défi aussi pour l'enseignant qui, lui aussi continue à perfectionner ses connaissances.

\section{Références}

Cipra, A., \& Hermelin, C. (1982). La presse : un outil pédagogique. Paris: Edition Retz Komatsu, S. (2000). Une analyse pédagogique et tecbnique de sites internet pour un emploi en autonomie des apprenants du F.L.E. Retrieved August 31, 2018, from http://skomatsu.free.fr/articles/Cef2000.pdf

L'utilisation de la vidéo dans l'enseignement des langues vivantes (n.d.). Retrieved September 5, 2018, from http://media.education.gouv.fr/file/97/6/5976.pdf

Tagliante, C. (2006). La classe de langue. Paris: Clé International.

Tissera, A., Sansberro, E. \& Carrizo, E. (2012). Les médias en tant qu'outils pédagogiques en classes de langue étrangère. Retrieved August 25, 2018, from http://www.didacticale.unlu.edu.ar/sites/www.didacticale.unlu.edu.ar/files/site /Tissera,\%20Carrizo,\%20Sansberro\%20I.pdf 


\title{
Task-Based Syllabus in Medical English Courses: A Journey towards Learning Independence
}

\author{
LORNA DUBAC NEMET \& KSENIJA BENČINA
}

\begin{abstract}
Students of medicine, just like all other future academic citizens, need to step up when it comes to shifting from general English to specific professional language. Nowadays, maybe more than ever in history, there is a pronounced need for students to master their medical English skills in order to develop both vertically and horizontally within their profession. The foundations for the successful communication and interaction, as well as research and training are supposed to be laid within the formal Medical English curriculum, comprised of six 20-hour modules equally distributed within each year of the medical study programme. The expected outcomes were directed towards the development of the research skills (recherché), compilation/designing and presentation of medical topics from the courses completed in each year of the medical study programme, respectively, with the exception of the first year. This multi-level activity provides the opportunity for the students to broaden their vocabulary registers, to link the data they come across while researching to the pieces of information they have received from their medical course instructors in Croatian, at the same time engaging in active learning through self-development.
\end{abstract}

Keywords: - medical English - medical topics - knowledge and skill-integrated concept $\cdot$ task-based syllabus - MS PowerPoint presentation $\bullet$

CorResPONDENCE AdDResS: Lorna Dubac Nemet, MA, Senior Lecturer, J. J. Strossmayer University of Osijek, Faculty of Dental Medicine and Health and Faculty of Medicine, Cara Hadrijana 10e / J. Huttlera 4, 31000 Osijek, Croatia, e-mail: ldnemet@fdmz.hr \& ldnemet@mefos.hr. Ksenija Benčina, MA, Senior Language Instructor, J. J. Strossmayer University of Osijek, Faculty of Education, Cara Hadrijana 10d, 31000 Osijek, Croatia, e-mail: kbencina@foozos.hr. 


\section{$1 \quad$ Introduction}

Being a University graduate implies being prepared to commit to core values of diversity and equality, engaging with peers in one's own discipline both nationally and internationally adhering to relevant professional standards. In order to successfully accomplish those goals, one has to be able to develop both horizontally and vertically.

Horizontal development involves developing knowledge and skills necessary for strengthening personal competencies, such as communication, active listening and level of expertise. Vertical development, on the other hand, refers to development of mental complexity as well as emotional intelligence. Such a development is possible in a learning environment that combines challenge and support. In that way, it enables an individual to adapt to future demands, as well as upcoming changes, efficiently recognizing emerging trends, problems and opportunities (Kegan \& Lahey, 2009).

\section{$2 \quad$ Signposting towards ...}

\subsection{English for Specific Purposes (ESP)}

English for Specific Purposes dates back to the period of the end of the Second World War, when, after the peace treaty was signed, the entire world's population engaged in rebuilding of their lives. That resulted in blooming of science, technology and economics, especially in the United States of America, therefore prompting the role of English as lingua franca, international language for communication and exchange of ideas (Hutchinson \& Waters, 1987).

The second boosting factor was a communicative approach that was fostered among the linguists, stressing the importance of language contextualisation. Consequently, it all led to a shift form teacher-centred to learner-centred teaching, preparing the students of today to be efficient professionals of tomorrow. 


\section{$2.2 \quad$ Knowledge-Based Society}

In line with the paradigm of the $21^{\text {st }}$ century learning promoted by the Organisation for Economic Co-operation and Development (OECD) educational analyses, the educated workers need to be equipped with integrated and usable knowledge, should be able to grasp complex concepts and generate new ideas, efficiently expressing their opinions and elaborating their decisions. The prerequisite for the fore-mentioned learning outcomes is adequate learning approach towards reading literacy (critical evaluation of the references encountered as a part of recherché process), as well as addressing of the concept of problem-solving, encouraging and reinforcing the ability to analyse the situation, reach decision(s) and manage multiple, simultaneous challenges. The educated professionals of tomorrow are aware of their need for constant investment in their professional development, and beyond doubt, highly motivated to assume responsibility for successful adaptation to a changing world (OECD, 2003b).

\subsection{English for Medical Purposes (EMP) Needs Analysis}

Just like in any other ESP, learners' language needs are the starting point of the EMP course design, tailored to students' level of knowledge and skills in general English, their motivation, as well as their future use of professional English. So, the first question that comes up is: What are the students going to need English for, both during their studies and after graduation?

It is a well-known fact that medicine is one of the most propulsive and evolving sciences in the world. What is a novelty today will be old news tomorrow. Publication of scientific and professional papers, as well as presentation of research advances at international congresses and symposia are beyond doubt inevitable part of a professional development. Consequently, the focus of the EMP course should be on the appropriate use of the professional literature in English (books, research papers, internet resources) and the development of presentation skills (Žmegač Horvat, 2011). 


\section{Task-Based Language Teaching (TBLT)}

\subsection{Communicative Language Teaching (CLT) - a base for TBLT}

Communicative language teaching (CLT) rests upon a notion that language is more than just a bunch of grammatical rules and exceptions to the rule, which needs to be memorized. In view of that, Nunan and Nunan (2004) stress the importance of educating individuals capable of communicating in the target language.

Task-based language teaching provides tools for realization of CLT approach to language syllabus design and methodology.

A pedagogical task, as defined in Richards and Rogers (1986), is “... an activity or action which is carried out as the result of processing or understanding language (i.e. as a response). (...) The use of a variety of different kinds of tasks in language teaching ...provides a purpose for a classroom activity which goes beyond the practice of language for its own sake".

By employing TBLT, one approaches syllabus design in a 'non-traditional' way (analytical approach), whereby the learners are presented with a bunch of language items, which they are supposed to analyse, as opposed to a 'traditional' way (synthetic approach) in which the instructor's role is to simplify the learning by breaking it into smaller parts and introducing them separately, from simpler to more complex content (Wilkins, 1976).

One of the most valuable concepts of TBLT is definitely experiential learning (learning by doing), which de-passivizes the learner (intrinsic motivation), providing opportunities for personal growth by reflecting on experience in a process of self-directed learning (Kohonen, 1992).

\subsection{Task-Based Language Teaching (TBLT) in EMP Courses}

Starting from the premise defined by Prabhu (1987) that language is for the most part acquired on a subconscious level "through the operation of some internal system of abstract rules and principles", when the learner is focused on task completion and not the language, what came as a logical sequel in EMP syllabus 
design was the decision to make the most of six 20-hour modules by implementing task-based syllabi. The expected outcomes were directed towards the development of the research skills (recherché), compilation/designing and presentation of medical topics from the courses completed in each year of the medical study programme, respectively, with the exception of the first year.

In that way, students develop all four language skills, so-called LSRW skills (listening, speaking, reading and writing). A receptive language skill - reading (skimming, scanning) is used while searching through references and it attributes to students' increased flexibility as readers by careful use of resources (time management), whether they search for a specific piece of information (scanning) or just go through a reference to see if it is worth reading in detail (general overview). Writing a summary (shorter or longer synopsis of the presentation) based on the selected pieces of information helps organize the data to be presented by providing blueprint for structural organisation of the slides. Both reading and writing, along with speaking to a certain extent (practicing the presentation at home), belong to the pre-presentation phase.

During the presentation, which takes place in the classroom in front of the teacher and colleague students, the two remaining language skills are in focus: speaking (the student presents the selected medical topic with the help of MS PowerPoint) and listening (colleague students).

The role of the teacher in such a student-centred environment is according to Van den Braden (2016) that of a "mediator of language learning, motivator and organizer". In cooperation with subject teachers, the EMP teacher selects the content (a list of medical topics already mastered by students as a part of the main medical curriculum in Croatian), whereby the students are welcome to suggest medical topics of their own, as long as they are within the scope of the main medical curriculum for the corresponding year of study.

As a part of a pre-task activity, the EMP teacher provides guidelines for successful production of MS PowerPoint presentation of the chosen medical topic, suggests the best tactics for choosing reliable Internet (and other) resources, as well as discusses students' needs and goals, with the purpose of enhancing their motivation (reasonable challenge and appropriate support). 
The second stage "the task" involves out-of-classroom preparation and actual execution of the task by students: a 10-minute presentation of the selected medical topic using MS PowerPoint. Upon the end of the task phase, the students are supposed to receive teacher's feedback (post-task), i.e. the teacher comments on the task performance and language development (Van den Branden, 2016).

Knowledge and skill-integrated approach advocated by many researchers brings authentic language and real content to a classroom setting, whereby Medical English becomes the language of professional interaction to its full extent, simulating the future congresses, symposia or conferences. Additionally, such an approach provides the opportunity for the teacher to assess multiple skills at the same time.

Along with the knowledge component of the task, in which students are to demonstrate specific knowledge regarding the production of MS PowerPoint presentation, and background knowledge, where they link as well as use pieces of information already acquired during courses of main medical curricula, the task itself encompasses a skill component.

A skill component consists of using cognitive, discourse and linguistic skills. Cognitive skills are basically observed as information processing skills and are made of eight core cognitive capacities: sustained attention, response inhibition, speed of information processing, cognitive flexibility, working memory, category formation and pattern recognition. The most important one in relation to the process of teaching and learning is definitely Sustained Attention. Namely, without the ability to observe, listen to, follow and think about a certain classroom task, there will not be any new learning. Consequently, the development of information processing skills settles upon the balance between student's ability to sustain attention and teacher's ability to provide tasks which are both challenging and interesting to students.

Both Sustained Attention and Response Inhibition contribute to Speed of Information Processing, which, in turn, increases Sustained Attention. All three of them, on the other hand, contribute to successful multitasking (Multiple Simultaneous Attention). Cognitive Flexibility is about re-thinking and relearning, in order to be able to apply skills and/or concepts learned in one setting to a new setting (concept-based learning). The ability to organize pieces of 
information into categories (Category Formation) accelerates Information Processing and improves memorization, leading towards abstract thought within higher level abilities like application, analysis and evaluation, whereas Pattern Recognition helps anticipate future sequence of events drawing on all other core cognitive processes. In that way, those processes are integrated for the purpose of creative problem solving (Cognitive Skills: Why The 8 Core Cognitive Capacities (n.d.)).

By employing medical terminology in English while reporting on their chosen medical topic, students are demonstrating mastery of the subject matter in their non-native language, bringing themselves closer to real life settings in the Republic of Croatia but also abroad (conferences, symposia, congresses).

Linguistic skills attributed to spoken and written language are being demonstrated through several language domains. Bloom and Lahey (1978) divide language into three separate but overlapping components: form, content and use. More precisely, within the language domain FORM the following components are being listed: phonology (appropriate use of phonological patterns while speaking/accurate spelling of words while writing), morphology (using morphemes correctly while speaking, understanding grammar while reading, appropriate use of grammar while writing) and syntax (using correct sentence structure elements when speaking and writing; understanding sentence structure while reading). Within the language component of CONTENT we can observe: semantics (appropriate choice of vocabulary: words combined to form sentences); and USE: pragmatics (understanding aspects of spoken language conversation; producing cohesive and relevant messages, conveying intended messages).

Additionally, the discourse skills that are being brought to the forefront are the proper use of the medical terminology when discussing a chosen medical topic. That means that the students are encouraged, for example, to use the medical English term "edema", instead of general English term swelling, "hypertension" instead of bigh blood pressure or "hematoma" instead of bruise. In that way students of medicine upgrade their vocabularies, linking medical terminology to already familiar general English terms, at the same time creating correlations between data and concepts acquainted with during courses of main medical curricula and 
those encountered during preparation for MS PowerPoint presentation in English.

Table 1: Example of a Task in Terms of its Knowledge and Skills Component (Task: MS PowerPoint Presentation of a Medical Topic), adapted from Gatbonton \& Gu (1994)

\begin{tabular}{|c|c|c|c|c|}
\hline \multicolumn{2}{|c|}{ KNOWLEDGE COMPONENT } & \multicolumn{3}{|c|}{ SKILLS COMPONENT } \\
\hline $\begin{array}{c}\text { SPECIFIC } \\
\text { KNOWLEDGE }\end{array}$ & $\begin{array}{l}\text { BACKGROUND } \\
\text { KNOWLEDGE }\end{array}$ & COGNITIVE SKILLS & $\begin{array}{l}\text { DISCOURSE } \\
\text { SKILLS }\end{array}$ & $\begin{array}{l}\text { LINGUISTIC } \\
\text { SKILLS }\end{array}$ \\
\hline $\begin{array}{l}\text { Rules and } \\
\text { procedures } \\
\text { students should } \\
\text { know to carry } \\
\text { out their task } \\
\text { (presentation of a } \\
\text { medical topic) }\end{array}$ & $\begin{array}{l}\text { Understand } \\
\text { implications and } \\
\text { consequences } \\
\text { (Students use it to } \\
\text { connect new } \\
\text { information to } \\
\text { old one: medical } \\
\text { topics in } \\
\text { Croatian) }\end{array}$ & $\begin{array}{l}\text { Infomation processing } \\
\text { skills: } \\
\text { - } \quad \text { Sustained attention } \\
\text { - } \quad \text { Response inhibition } \\
\text { - } \quad \begin{array}{l}\text { Speed of information } \\
\text { processing }\end{array} \\
\text { - } \quad \text { Cognitive flexibility } \\
\text { and control } \\
\text { - Multiple simultaneous } \\
\text { attention } \\
\text { - Working memory } \\
\text { - } \quad \text { Category formation } \\
\text { - } \quad \text { Pattern recognition }\end{array}$ & $\begin{array}{l}\text { Medical } \\
\text { discourse }\end{array}$ & $\begin{array}{l}\text { Capacity to } \\
\text { understand and } \\
\text { express themselves } \\
\text { both in written } \\
\text { and oral form } \\
\text { - Phonology } \\
\text { - Morphology } \\
\text { - Syntax } \\
\text { - Semantics } \\
\text { - Pragmatics }\end{array}$ \\
\hline
\end{tabular}

This multi-level activity therefore provides the opportunity for the students to broaden their vocabulary registers (new as well as recycled relevant vocabulary and multiword units of medical terminology), to link the data they come across while researching to the pieces of information they have received from their medical course instructors in Croatian, at the same time engaging in active learning through self-development.

In order to harvest the most out of Medical English course, it is of utmost importance that students are able to grasp the fact that they are gaining benefits from their efforts, which are best represented by working on specific study skills. The development of student's self-assessment skills remains an 'added value' contributing significantly to future independent learning as an indispensable part of lifelong learning process.

\section{References}

Bloom, L., \& Lahey, M. (1978). Language development and language disorders. New York: Wiley.

Cognitive Skills: Why The 8 Core Cognitive Capacities (n.d.) Retrieved from https://www.c8sciences.com/about/8ccc/ 
Gatbonton, E., \& Gu, G. (1994). Preparing and implementing a task-based ESL curriculum in an EFL setting: Implications for theory and practice. TESL Canada Journal, 11(2), 9-29. $\quad$ Retrieved http:// files.eric.ed.gov/fulltext/EJ493129.pdf

Hutchinson,T., \& Waters, A. (1987). English for specific purposes: A learning-centred approach. Cambridge: Cambridge University Press.

Kegan, R., \& Lahey, L. L. (2009). Immunity to change: how to overcome it and unlock potential in yourself and your organization. Boston, Mass: Harvard Business Press.

Kohonen, V. (1992). Experiential language learning: Second language learning as cooperative learner education. In D. Nunan (Ed.), Collaborative language learning and teaching (pp. 14-39). Cambridge, UK: Cambridge University Press.

Nunan, D., \& Nunan, D. (2004). Task-based language teaching. Cambridge, UK: Cambridge University Press.

OECD (2003b), Learners for life - Student approaches to learning, OECD, Paris.

Prabhu, N. S. (1987). Second language pedagogy. Oxford: Oxford University Press.

Richards, J. C., \& Rogers, T. S. (1986). Approaches and methods in language teaching: A description and analysis. Cambridge: Cambridge University Press

Van den Branden, K. (2016). The role of teachers in task-based language education. Annual Review of Applied Linguistics, 36, 164-181. doi:10.1017/S0267190515000070

Wilkins, D. (1976). Notional syllabuses. Oxford: Oxford University Press. doi:10.1037/11193-000

Žmegač Horvat, A. (2011). Work in progress: Developing a medical English curriculum at the University Of Zagreb School Of Medicine, Strani jezici, 40, 221-236. 


\title{
Nursing Case Study in English: Third-Year Written
}

\section{Assignment}

\author{
LORna Dubac NEMET \& KSEnija BENČInA
}

\begin{abstract}
Teaching English to the nursing students involves equipping them with the knowledge and skills that will complement their nursing knowledge and skills in Croatian. Calling upon motivation intensively accelerates both teaching and learning processes, since motivation arises from the fact that the students are able to perceive the practical application of the ENP (English for Nursing Purposes) course they are taking part in. The prospects of the future career strongly emphasize the fact that being a health professional means being a lifelong learner. For that reason, the foundations need to be set within the ENP curriculum, preparing the students to be globally competitive critical thinkers and communicators, competent to link theory to practice, organize and categorize pieces of information, supported by best practice. Nursing case study in English, a third-year written assignment, therefore presents the opportunity for the students to provide an account of the surgical experience of a particular surgical patient they have been assigned to monitor and provide with a patientfocused nursing healthcare, using medical terminology in English. By doing that, they are able to demonstrate the nursing focus which incorporates assessment skills, clinical reasoning, evidence-based research and best practice.
\end{abstract}

Keywords: - English for nursing purposes - nursing - CLIL (Content and Language Integrated Learning) $\bullet$ case study $\bullet$ lifelong learning •

\footnotetext{
CORRESPONDENCE ADDREss: Lorna Dubac Nemet, MA, Senior Lecturer, J. J. Strossmayer University of Osijek, Faculty of Dental Medicine and Health and Faculty of Medicine, Cara Hadrijana 10e / J. Huttlera 4, 31000 Osijek, Croatia, e-mail: ldnemet@ffdmz.hr \& ldnemet@mefos.hr. Ksenija Benčina, MA, Senior Language Instructor, J. J. Strossmayer University of Osijek, Faculty of Education, Cara Hadrijana 10d, 31000 Osijek, Croatia, e-mail: kbencina@foozos.hr.
} 


\section{$1 \quad$ Introduction}

Some hundred and eighty years ago, nursing, or at least some sort of nursing care, was being provided exclusively by servants. Therefore, a notion of a single woman, coming from a wealthy family, at her prime age for marriage opting for taking care of sick and poor, drew a lot of attention. Being far more than just a Lady with the Lamp, Florence Nightingale had shed light into dark, filthy and poorly organized hospital settings, putting an emphasis on the fact that " ... caring for the sick is not a business but a calling", a sense of inner voice providing the right amount of enthusiasm. Florence Nightingale revolutionized patients' healthcare, setting the foundations for professional nursing practice, being well aware of the importance of continuous education and training. She was the founder of the first scientifically based nursing school at St Thomas's Hospital in London and her graduates from then on had spread her nursing concepts and reforms worldwide (Sweet, 2014).

Following the root principles of Florence Nightingale, generations of nursing educators strived to develop a globally competent student. One of the methods how to accomplish it is definitely by employing communication both within the national borders as well as cross-culturally, fostering the global literacy concept.

\section{Content, Language, Concept, Evidence}

\subsection{Integration of Content and Language in Nursing: Content and Language Integrated Learning (CLIL)}

In 1990s, some thirty years after the emergence of English for Specific Purposes (ESP), dually focused Content and Language Integrated Learning (CLIL) appeared. Although separated by a certain time gap, they share the common characteristics without one being a copy or variant of the other. The similarity of those two internationally focused approaches is that they combine language teaching with context(s), whereby they exhibit difference in approach: ESP being more language-driven, whereas CLIL is more of a content-driven approach.

In English for Nursing Purposes (ENP), which is part of the ESP, CLIL approach elements remain a valuable asset: they provide the opportunity to engage students in a student-centred teaching, in which they will assume 
independence and responsibility for their learning and development (Tzoannopoulou, 2015).

Nursing students do recognize the importance of communication skills in English. In the research conducted among the $1^{\text {st }}$ and $3^{\text {rd }}$ year nursing students of the Professional Nursing Study (Technical College in Bjelovar), the results pointed towards their understanding of the importance of practical use of communicational skills within the clinical setting (predominantly speaking; reading and writing were not recognized as equally important, although positive attitudes are being observed) (Badrov \& Jurkovic, 2017).

\subsection{Language - Learning Objectives vs Learning Styles}

What do we want students to learn and how do they accomplish it? It is, unfortunately, not as simple as it maybe sounds. First of all, what we want them to learn should be carefully assessed after the needs analysis, because, if we want motivated students, then we should meet their contemporary/future career needs. In case of full-time students, that will be their projection on what they presume they would need once they start their nursing career. On the other hand, part-time students, for the most part already employed in nursing setting, have a concrete idea about skills that need to be mastered or just polished. The disadvantage appearing in part-time students is the fact that the majority of them had finished their last English as a Foreign Language (EFL) course approximately 15 to 20 years ago, resulting in less firm language foundations to build upon while engaging in ENP (English for Nursing Purposes) course. Consequently, the parttime students tend to be more attracted to a surface approach to learning.

\subsubsection{Deep vs Surface Approach}

In the mid-70s of the past century, two psychologists, Marton and Säljö (1976), published a revolutionary paper introducing and elaborating the concepts of deep and surface approach to learning. Basically, active learners adopt deep approach to learning, they are intrinsically motivated, curious and enjoy team work and exchange of opinions in a form of discussion. Surface approach to learning, on contrary, is the choice of a passive learner. They memorise facts in order to pass the exam, and passing the exam is their motivation. 
Our duty as ESP teachers is to encourage deep learning, for it surpasses memorisation alone, bringing notions of creating structural relationships, recognizing potential gaps and raising questions which will be a follow up to the constant process of professional and personal development. Keeping all of that in mind, it is only logical that we need to employ scaffolding principle defined by Hammond and Gibbons (2005) as support provided to learners so that they can understand and accomplish tasks, which they otherwise could not have managed on their own. In that way, our playfield is located in the students' zone of proximal development (ZPD), where we are able to gradually withdraw the support, as soon as we make sure that the distance between the "actual developmental level" and "level of potential development" has been significantly reduced. The concept of ZPD was developed by Soviet psychologist Lev Vygotsky in the $20^{\text {th }}$ century and it was later on further developed and applied to various educational concepts (Vygotsky, 1978).

\subsubsection{Bloom's Taxonomy Adapted to ENP Courses}

Due to the fact that our ENP curriculum is made of three modules, in each study year of the university undergraduate nursing programme, the pyramidal revised Bloom's Taxonomy has proven to be a good starting point and framework for organizing learning objectives. By doing so, we are able to plan and launch the learning process, followed by a balanced and consequently conducted assessment.

The $1^{\text {st }}$ year ENP course rests upon remembering and understanding. Since it is for the most part an Introductory course (Introduction to morphology of medical terms, Introduction to basic nursing terminology in English), it employs a teacher-centred approach towards achieving factual knowledge (terminology, elements etc.) and partially conceptual knowledge (concept of nursing health care - English terminology).

Application and Analysis would be the key terms of the $2^{\text {nd }}$ year, building on the foundations set during the previous study year. During this course, students are able to demonstrate the nursing aspect of a healthcare in case of a particular disease/condition and differentiate between general English and medical English terminology in a nursing setting. In cognition, the knowledge of concepts and procedures is being put into the forefront, whereby theories and structures, 
together with subject-specific skills and methods, as well as the criteria when to opt for a certain procedure, are the core of pedagogical interchange. The second year ENP course fosters for the most part learner-centred approach, shifting the responsibility for learning to students, preparing them for the $3^{\text {rd }}$ year course.

The last year of the undergraduate nursing study involves the production of seminar paper in a form of a case study, followed by a short MS PowerPoint presentation. This final ENP course encompasses the highest levels of learning: Evaluating and Creating. While searching through data bases and other internet resources, looking for adequate references to support their theses (nursing diagnoses, interventions for a particular type of a surgical experience etc.), students are evaluating those sources using the strategic (metacognitive) knowledge (reading for purpose). In creating the final product of the undergraduate ENP curriculum, the students are reporting on a particular surgical patient they have been assigned to monitor and provide with a patientfocused nursing healthcare, using medical terminology in English.

By applying Bloom's taxonomy we are by no means limiting students in their development. Starting from the fact that our ENP course student groups are highly heterogeneous, it is only possible to set the midline course for the majority, which is then modified and adapted to specific needs of lower and upper level students, who are in the minority.

\section{Bloom's Taxonomy}

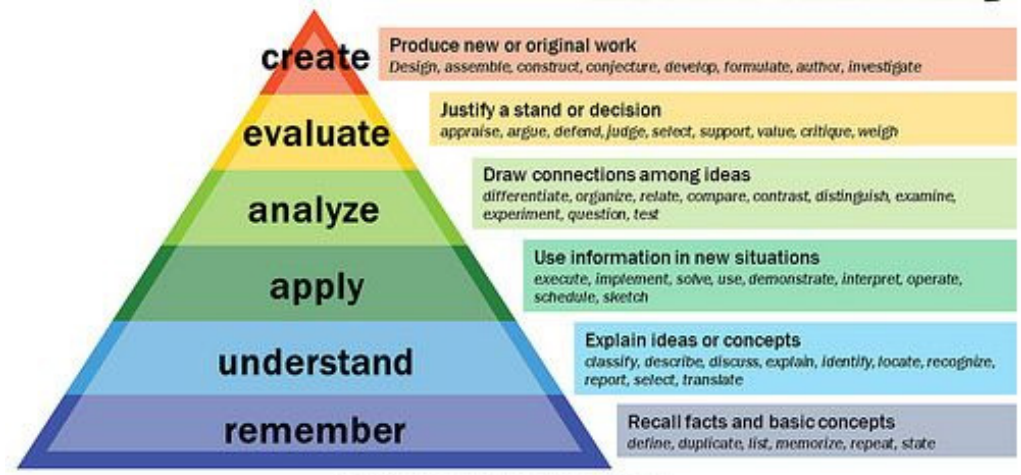

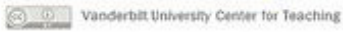

Figure 1: Bloom's Taxonomy (Revised). Courtesy of Vanderbilt University Center for teaching 
Visual Auditory Kinaesthetic (VAK) learning style model introduced by Dunn, Dunn and Price in 1984, has proven to be adequately valuable starting point in designing of ENP courses model. Since the students prefer various learning styles, we have tried to include as many as different teaching methods as possible, so that each student can recognise and make the most of a certain activity/task.

For Visual Learners, in the $1^{\text {st }}$ and $2^{\text {nd }}$ year we have prepared numerous MS PowerPoint Presentations, games, illustrations; target readings (skimming, scanning), and in the $3^{\text {rd }}$ year - contextual and comparative reading. Auditory Learners (although usually there are not many of them in ENP classes), will profit from discussions, oral sessions or just from listening to the tape recordings of a native English speaker. Those who are fans of physical activity ("learning by doing"), so-called Kinaesthetic Learners, will find themselves "at home" with hands-on training opportunities for active learning, role-plays and demonstrations.

Providing different types of learning experiences directly affects the student learning effectiveness, moreover, it increases their motivation and confidence, bringing them closer to structuralized thinking and equipping them with lifelong learning capacities.

\subsection{Concept-based Curriculum in Nursing}

Both globalisation and internationalisation have influenced higher education tremendously over last couple of decades. In view of that, a lot has changed in Nursing since the era of Florence Nightingale. Nurses nowadays receive a significant amount of schooling, therefore content saturation in a limited time poses a significant threat on both the nurses' motivation and their ability to think critically, while applying previous knowledge and experience.

The realities of the $21^{\text {st }}$ century Nursing call upon a method which will be able to shrink the "know" and "do" gap created over decades, a concept which will be concentrated on the broader principles and their application. $21^{\text {st }}$ century nurses are those healthcare workers that can shift from one patient to another, providing holistic, patient-centred care. For that reason, in order to educate a $21^{\text {st }}$ century nurse a shift has to be made towards predominantly student-centred learning, in which students will be encouraged to apply concepts from one 
nursing setting to another, recognizing patterns and anticipating risks, systematically observing while providing care, in short: by seizing authentic learning opportunities that mirror practice (Baron, 2017)

\subsection{Evidence-based practice in Nurse Education}

According to Melnyk and Fineout-Overholt (2005) evidence-based practice is defined as "a problem-solving approach to clinical practice" that integrates the use of best evidence combined with nurse's own clinical expertise and patient's preferences. By employing evidence-based practice, nurses are able to choose the interventions, which are to deliver the greatest chance of a successful patient outcome.

In order to have the nurses who practice evidence-based approach to patient healthcare, it is of utmost importance to integrate evidence-based concept into the nursing curriculum. The direct consequences of promoting evidence-based nursing care at all levels of nursing education, are among others: practical application of research and setting the foundations for continuous professional development and lifelong learning.

The role of the ESP teacher in this domain is aimed towards developing students' skills necessary for engaging with evidence and applying it to nursing practice. As a part of ENP courses, equally distributed over three years of the undergraduate study programme in Nursing, following a progressive pathway, the students are initially introduced to the basics of word formation (morphology of medical terms) and nursing concept terminology (nursing diagnoses, interventions, expected outcomes). In the $2^{\text {nd }}$ year, they practice elementary searching through internet resources, as well as data bases, deciding upon reliability and applicability, end product being a 10-minute MS PowerPoint presentation of a medical condition from a nursing perspective (nursing diagnoses, interventions, expected outcomes), using previously read journal articles.

The final challenge, and at the same time, the best test of the extent of development of literature-searching and writing skills is the $3^{\text {rd }}$ year written assignment - a nursing case study in English, which furthermore empowers the students to assume as well develop evidence-based practices, resulting in patientcentred, cost-effective and timely healthcare. 


\section{Case Study: Nursing Healthcare of the Surgical Patient}

The case studies as teaching methods emerged from Problem-based learning (PBL) educational approach. The benefits of introducing case studies to ENP courses are manifold; students are above all assuming independence in/responsibility for their learning process, developing the skills of searching, analysing and using the pieces of information from research papers, comparing it to their practical experiences (narrowing the gap between theory and practice by combining one with the other), developing the skills of reviewing the decisions, thereby engaging in reflective thinking processes, which further on help recognizing patterns when comparing cases (Frankel, 2009).

Case study approach helps develop transferable skills, among others: research and analysis, time management, group working, writing and presentation skills.

Along with bridging the gap between theory and practice, ENP curriculum also presupposes bridging the gap between higher education and the "real world". By providing opportunities to simulate real nursing setting, students are brought closer to the contemporary world of health care, scaffolded by their teachers, safely practising with a purpose of generating knowledge and skills which are potentially transferrable to a range of clinical settings. In that way, as reported by Crowe, Creswell, Robertson, Huby, Avery, and Sheikh (2011), students acquire understanding about the implementation of the interventions, potential gaps in their delivery, as well as why one strategy might be chosen over the other.

\section{References}

Armstrong, P. (n.d.). Bloom's Taxonomy [Image]. Retrieved from https://cft.vanderbilt.edu/guides-sub-pages/blooms-taxonomy/

Badrov, T., \& Jurkovic, I. (2017). Attitudes of nursing students toward the importance of communication skills in the English language. Journal of Applied Health Sciences, 3(2), 265-271. DOI:10.24141/1/3/2/12

Baron, K. A. (2017). Changing to concept-based curricula: the process for nurse educators. The Open Nursing Journal, 11, 277-287.

Crowe, S., Creswell, K., Robertson, A., Huby, G., Avery, A., \& Sheikh, A. (2011). The case study approach. BMC Medical Research Methodology, 11(1), 1-9. doi: 10.1186/14712288-11-100

Dunn, R., Dunn, K., \& Price, G. E. (1984) Learning Style Inventory. Lawrence, KS: Price Systems. 
Frankel, A. (2009). Nurses' learning styles: promoting better integration of theory into practice. Nursing Times, 105(2), 24-27.

Hammond, J., \& Gibbons, P. (2005). Putting scaffolding to work: the contribution of scaffolding in articulating ESL education. Prospect, 20(1), 6-30. Retrieved from http://www.ameprc.mq.edu.au/docs/prospect_journal/volume_20_no_1/20_ 1_1_Hammond.pdf

Marton F., \& Säljö, R. (1976). On qualitative differences in learning I - outcome and process. British Journal of Educational Psychology, 46, 4-11. Retrieved from https://www.learning.ox.ac.uk/media/global/wwwadminoxacuk/localsites/oxf ordlearninginstitute/documents/supportresources/lecturersteachingstaff/resour ces/resources/Student_Approaches_to_Learning.pdf

Melnyk, B., \& Fineout-Overholt, E. (2005). Evidence-based practice in nursing and healthcare: A guide to best practice. Philadelphia: Lippincott, Williams\&Wilkins.

Sweet, V. (2014, March 4). Far More Than a Lady With a Lamp. New York Times. Retrieved from https://www.nytimes.com/2014/03/04/health/florencenightingales-wisdom.html

Tzoannopoulou, M. (2015). Rethinking ESP: Integrating content and language in the university classroom. Procedia - Social and Behavioral Sciences, 173,149-153.

Vygotsky, L. S. (1978). Mind in society: The development of higher psychological processes. Cambridge MA: Harvard University Press. Retrieved from https://www.simplypsychology.org/simplypsychology.org-vygotsky.pdf 


\title{
Using Learner Corpus Evidence in Error Analysis
}

\author{
GORANA DUPLANČIĆ ROGOŠIĆ
}

\begin{abstract}
Research in applied linguistics has emphasized the importance of learner errors in foreign language acquisition. Within the pedagogical framework, analyzing learner error is indispensable as it provides information on what the learners (should) have acquired by a certain stage. It is a valuable source of information for teachers, material designers, etc. because it enables them to highlight typical problems and to provide the most useful language input to learners. A learner corpus was compiled using assignments by first-year students at the University of Split. The purpose of the corpus was to investigate the problem areas and patterns of errors that are common to specific non-native speakers of English with the aim of developing data-based teaching and of designing learning materials that would be more effective than the ones currently used. Corpus analysis revealed learners' errors and provided useful information on what language areas need to be studied more.
\end{abstract}

Keywords: - non-native speakers - Business English learner corpora $\bullet$ error $\bullet$ error analysis $\bullet$

\footnotetext{
Correspondence AdDress: Gorana Duplančić Rogošić, MA in Linguistics, Senior Lecturer, University of Split, Faculty of Economics, Business and Tourism, Cvite Fiskovića 5, 21000 Split, Croatia, e-mail: gduplanc@efst.hr.
} 


\section{$1 \quad$ Introduction}

For many years, English language teaching (ELT) had focused on teaching grammar and developing grammar competence because it was believed that vocabulary would be acquired by itself, thus giving vocabulary a secondary status. In the 1970s, the focus moved to the importance of vocabulary in foreign language teaching/learning with the rise in popularity of the communicative approach (Schmitt, 2000). It emphasized the importance that languages have for meaningful interaction and for accomplishing tasks. However, to accomplish tasks using language and to have a meaningful interaction a mastery of both grammar and lexis is needed. Research has shown that many language irregularities cannot be explicitly labelled as grammatical or lexical but that there are rather various degrees of errors that depend on the extent of the generalizability of the rule infringed (Salem, 2007, p. 218).

While learning a foreign language, the learner will make errors, which is a part of the normal learning process. When the teacher understands the nature of his learners' errors and their possible sources, he can make better decisions, which will positively affect his performance and fulfill current pedagogical and professional demands (Londoño Vásquez, 2008, p. 144). This, therefore, makes error analysis a fundamental and relevant tool in language teaching.

\section{Errors and Error Analysis}

An error analysis should start with a clear and straightforward definition of an error. However, a review of available Second Language Acquisition (SLA) literature shows that there are many definitions of error. Dulay, Burt, and Krashen (1982, p. 138) define errors as parts of conversation or composition...that deviate from some selected norm of mature language performance. Chun, Day, Chenoweth, and Luppescu, (1982, p. 538) state that an error is the use of a linguistic item in a way, which, according to fluent users of the language, indicates faulty or incomplete learning. Brown (2007, p. 324) defines an error as an idiosyncrasy in the language of the learner that is a direct manifestation of a system within which a learner is operating at the time. The common feature of the definitions is that errors are language forms that violate the rules and/or norms of the target language. 
Applied linguistics researchers usually distinguish between performance errors and competence errors. Performance errors are errors that a learner makes when he is tired and/or hurried and are corrected immediately when he notices it. Competence errors, on the other hand, are more serious types of errors as they reflect inadequate learning. Competence errors are made systematically by the learner so they cannot be corrected easily. These errors reveal the learner's linguistic competence in the foreign language and his limitations in what he is expected to know at a given level. Some authors (Richards, 1971; Corder, 1981; Brown, 2007) distinguish between mistakes, which are performance errors, and errors, which are competence errors. Errors discussed in this paper are competence errors.

Although the concept of errors refers to the violation of the rules and/or norms of the target language, the view on errors should nonetheless be a positive one as errors reflect the fact that learning is taking place. Errors are an inevitable and necessary part of the natural process of learning (Ancker, 2000; Olasehinde, 2002; Brown, 2007, p. 257). They also hold some of the key to the understanding of the process of second language acquisition (James, 2013; Candling 2001, p. 69).

A systematic analysis of errors has a tri-fold benefit. It enables the teacher to assess the areas of language that the learner needs to study more, shows him the path the learner is taking towards the mastery of a foreign language and how far he has progressed on that path. Error analysis also helps teachers adapt their teaching to match the learners' actual and concrete language knowledge rather that the presumed one. It is also useful for researches as it provides evidence on strategies or procedures learners use when learning a language. Finally, it is also useful for learners as it tells them how correct their guesses on the correct use of a language are.

\section{2}

The research

This research tries to explore the most frequent errors students make in specific writing tasks, namely emails, with the aim of making this type of written communication more efficient. The general objective of the research is to analyze the errors produced by foreign language learners in their acquisition process. The specific objectives are to identify, describe, explain and evaluate those errors and provide suggestions on the changes that need to be introduced into the teaching practice in relation to the specific writing task. 
Email was chosen because it is one of the most commonly used forms of communication in the world. In the world of business, emails are used to make requests, send results, instructions, minutes of meetings, place and acknowledge orders, etc. E-mails are an effective and a fast mean of communicating with customers and suppliers, both nationally and internationally. They are also usually brief and relatively informal, as compared to classic business letters.

\subsection{Participants}

Research participants are first-year students at the Faculty of Economics, Business and Tourism, University of Split studying at a professional study programme of Small Enterprise Management during the academic year 2017/2018. They are pre-service learners and non-native speakers of English. Their level of English is at least at the B1 level of the Common European Framework of Reference for Languages (CEFR), which is confirmed by the fact that they had to pass the lower level of English at the State Matura Exam which is a prerequisite to enroll into any type of studies in the Republic of Croatia. A total of 101 students participated in the research. Research participants have three lessons (each lasts 45 minutes) of Business English once a week during the first two semesters.

\subsection{Methodology and procedures}

The error analysis in this research refers to the analysis of errors made by research participants in a selected type of written task, i.e. emails. Corder (quoted in Londoño Vásquez, 2008, p. 136) proposes five steps in error analysis research in order to reach that objective. These steps, which are loosely followed in this research, are:

1. Collection of a sample of learner language;

2. Identification of errors;

3. Description of errors;

4. Explanation of errors;

5. Evaluation of errors. 
The procedure was as follows. In class, students were first taught about the general characteristics of email communication. Then, they did language tasks to learn the relevant phrases, vocabulary and grammar elements used in the language of orders. Next, students, who were working in pairs, wrote two emails each, one placing an order (to the other student) and one replying to an order (placed by the other student). Details on what information the email on placing an order and the one on replying to an order had to include were provided to students. Last, students uploaded the partner's email placing an order and their own email replying to the order on moodle, an e-learning platform used at the Faculty of Economics, Business and Tourism in Split. Finally, the sample of learner language was downloaded from moodle and a learner corpus was compiled. The learner corpus used in this research consisted of a total of 202 emails, 101 of placing an order and 101 of replying to an order. The corpus contained 14,147 words, 879 sentences and 17,594 tokens. AntConc (Anthony, 2010), a freeware corpus analysis toolkit for concordancing and text analysis, was used to identify errors. The description, explanation and evaluation of errors are provided in the following section.

\section{$2.3 \quad$ Findings}

An analysis of participants' errors revealed that errors could be divided into three broad categories: discourse-related, grammatical and lexical errors. The line between these categories is not a strict one and errors often overlap as the ability to use a language includes both grammatical and lexical knowledge and the ability to make a coherent message.

The main errors in the discourse section were lack of paragraphs and lack of cohesion/coherence. In terms of lack of paragraphs student either wrote each sentences in new line or wrote the entire mail into one paragraph as illustrated in the following two examples in table 1. 
Table 1: Types and examples of discourse-related errors

\begin{tabular}{|c|c|}
\hline Error type & Example of error identified \\
\hline $\begin{array}{l}\text { Lack of } \\
\text { paragraphs - } \\
\text { each } \\
\text { sentence in a } \\
\text { new line }\end{array}$ & $\begin{array}{l}\text { Dear / first name/ } \\
\text { I would like to place an order for } 30 \mathrm{RP} 250 \mathrm{YZ} \text { laptops. Please find } \\
\text { attached the order form. } \\
\text { Do you give a discount for bulk, orders? } \\
\text { What is the delivery time? } \\
\text { I look forward to receiving your confirmation. } \\
\text { Best regards, } \\
\text { / first name/ }\end{array}$ \\
\hline $\begin{array}{l}\text { Lack of } \\
\text { paragraphs - } \\
\text { entire email } \\
\text { in one } \\
\text { paragraph }\end{array}$ & $\begin{array}{l}\text { Dear / first name/, } \\
\text { Thank you for your interest in our laptops. We do offer discounts on } \\
\text { bulk orders, such as yours. The price per laptop is } \$ 1.100 \text {, and we can } \\
\text { offer you a } 10 \% \text { discount for an amount of } 30 \text { laptops that you bave } \\
\text { ordered. Unfortunately, we must inform you that we have only } 25 \\
\text { RP250YZ laptops in stock, but we can also offeryou RP250S instead. } \\
\text { The delivery time is } 10 \text { days from the date of confirmed order. If that is } \\
\text { okay with you, please let us know, looking forward to your reply. } \\
\text { / first name+last name/ } \\
\text { IT King Supplies }\end{array}$ \\
\hline $\begin{array}{l}\text { Lack of } \\
\text { cohesion }\end{array}$ & $\begin{array}{l}\text { - Hope you can find time to answer us as soon as possible so that } \\
\text { our work can continue without any halt. } \\
\text { - Can you give us a quick reply and I hope we will cooperate. }\end{array}$ \\
\hline
\end{tabular}

The lack of cohesion shows inadequate grammatical and/or lexical linking sometimes within the entire email and sometimes in individual sentences. 
The following group of mistakes refers to grammatical errors that can be divided into several categories as shown in table 2:

Table 2: Types and examples of grammatical errors

\begin{tabular}{|c|c|}
\hline Error type & Example of error identified \\
\hline $\begin{array}{l}\text { Plural form } \\
\text { used where } \\
\text { singular form } \\
\text { was required } \\
\text { or vice-versa }\end{array}$ & $\begin{array}{l}\text { - Since we are your regular customer and ordering a lots of } \\
\text { T-shirts, are you willing to give us any discount? } \\
\text { - If we can reach an agreement on this matters, we are sure } \\
\text { that we can do more business with you in the future. } \\
\text { _ We need this items by the end of January. }\end{array}$ \\
\hline $\begin{array}{l}\text { Wrong tenses } \\
\text { used or } \\
\text { wrong tense } \\
\text { formation }\end{array}$ & $\begin{array}{l}\text { - I will attached an order form. } \\
\text { - I have already buy laptop from your company } \\
\text { IT King Suppliers. } \\
\text { - } \quad \text {... because we are a regular customer since when you } \\
\text { start with business. } \\
\text { - If it isnt a problem we would also like to know how } \\
\text { much it will takes to delivery the goods. }\end{array}$ \\
\hline $\begin{array}{l}\text { Misuse of } \\
\text { prepositions }\end{array}$ & $\begin{array}{ll}\text { - } & \text {...give discount for regular costumers... } \\
\text { - } & \text {...place an order of } 30 \mathrm{RP} 250 \mathrm{YZ} \text { laptops ... } \\
\text { - } & \text {...place an order on } 30 \mathrm{RP} 250 \mathrm{YZ} \text { laptops ... } \\
\text { - } & \text { We are interested on your products ... } \\
\text { - } & \text { We are interested for your products ... } \\
\text { - } & \text { We can dispatch the order till Monday ... }\end{array}$ \\
\hline $\begin{array}{l}\text { Omission of } \\
\text { prepositions }\end{array}$ & $\begin{array}{l}\text { - } \quad \text {..Thank you for your email } 14^{\text {th }} \text { January } \\
-\quad \text { We can supply the items one week } \\
-\quad \ldots \text { instead RP250YZ model. }\end{array}$ \\
\hline $\begin{array}{l}\text { Omission of } \\
\text { articles }\end{array}$ & $\begin{array}{ll}- & \text { I am attaching order form } \\
- & \text { What is delivery time } \\
- & \ldots \text { working for publishing company } \\
- & \text {...on bulk orders for me as loyal customer }\end{array}$ \\
\hline
\end{tabular}




\begin{tabular}{|c|c|}
\hline $\begin{array}{l}\text { Misuse of } \\
\text { articles }\end{array}$ & $\begin{array}{l}\text { - Can I get an discount on bulk orders? } \\
\text { - Could you please tell us which sizes do you need or } \\
\text { would you like an universal size? } \\
\text { - } \quad \text { I'd like to place an order for a polyester T-shirts for my } \\
\text { university's sports teams. } \\
\text { - We are offering the } 15 \% \text { discount for orders of } 100 \\
\text { and more T-shirts. }\end{array}$ \\
\hline $\begin{array}{l}\text { Unnecessary } \\
\text { insertion of } \\
\text { articles }\end{array}$ & $\begin{array}{l}\text { - We are the regular customers but there are two things } \\
\text { we would like to know. } \\
\text { - I would be grateful if you give me a discount for buy in } \\
\text { a bulk... } \\
-\quad \text { Please find the attached the order form including our } \\
\text { payment details in this email ... } \\
-\quad \text { I'm interested in if you have any } a \text { discount ... }\end{array}$ \\
\hline
\end{tabular}

The final group of errors can be classified as lexical errors that can be divided into several subtypes as illustrated in table 2 .

Table 3: Types and examples of lexical errors

\begin{tabular}{|c|c|}
\hline Error type & Example of error identified \\
\hline $\begin{array}{l}\text { Wrong } \\
\text { collocations }\end{array}$ & $\begin{array}{l}\text { - Do you have any discounts on this order? } \\
\text { - Normal price per T-shirt is } \$ 25 \text { but. }\end{array}$ \\
\hline $\begin{array}{l}\text { Wrong spelling } \\
\text { - no meaning } \\
\text { of the } \\
\text { misspelled } \\
\text { word }\end{array}$ & $\begin{array}{l}\text { - } \quad \text { abot, abouth, abour } \\
-\quad \text { qountity, quantiny, quontitiy } \\
\text { - } \quad \text { unfourtanetly; expirience; beacues; recieved }\end{array}$ \\
\hline $\begin{array}{l}\text { Wrong spelling } \\
\text { - another } \\
\text { meaning of the } \\
\text { misspelled } \\
\text { word }\end{array}$ & $\begin{array}{l}\text { - We would be extremly graceful if they come } \\
-\quad \text {...more shirts for out sports team } \\
-\quad \text {...colleagues who are playing in our university time... } \\
-\quad \text { Can you please find attached the order from... } \\
-\quad \text { Please find enclosed your offer but before than ... } \\
-\quad \text { Unite price is } \$ 25 \text { per T-shirt } \\
\text { - } \quad \text { We would be extremly graceful if they come }\end{array}$ \\
\hline
\end{tabular}

Having identified the errors made by research participants, they will be explained and evaluated in the following section. 
The emails written by research participants make up a small learner corpus which was compiled with the purpose of identifying problematic areas and with the aim of providing suggestions for developing relevant pedagogical materials. The findings of learner corpus analysis illustrate the most typical errors made by research participants that were classified into three broad categories, i.e. grammar, lexis and discourse. However, it was shown that many errors cannot be labelled as strictly grammatical, lexical or discourse-related.

Some errors are caused by vocabulary deficiencies, which then has a negative impact on text cohesion. For example, if learners have not mastered the phrase Please find attached (the order form) they will use sentences such as I enclose the order form in this email... or I'm sending you my order form in the attachment or In an attachment, you can find the order form. Although these sentences might be syntactically and semantically well-formed, they are pragmatically odd. This type of error means that it is important that in class learners practice relevant phrases more and that at home they learn those phrases, as it will make their e-mail communication easier and more natural.

The learners' mother tongue also plays a role in learning a foreign language and the influence of the mother tongue is evident in the examples in the previous paragraph. The examples are mostly word for word translations from research participants' mother tongue, e.g. I'm sending you my order form in the attachment is a translation of Šaljem V am narudžbenicu u privitku (in Croatian). Examples such as we would be happy to let you bave a discount of $25 \%$ or Delivery will come in 4-5 working days or Do you have that possibility or not are examples of interlingual, transfer or interference errors, which are errors due to the influence of the mother tongue.

Certain errors are developmental errors, which are caused by an inadequate mastery of the FL. Misuse and omission of prepositions, misuse, omission and unnecessary insertion of articles, wrong tense use or incorrect tense formation are all developmental errors. These errors, which were in this study classified as grammatical errors, show that the participants have not yet internalized some grammatical rules of the English language and have a limited linguistic competence. In terms of pedagogical materials, they should include revision of relevant tenses, e.g. present simple, past simple, present perfect and future tenses. 
Error analysis revealed many spelling mistakes. In some cases, the misspelled word has no meaning, as in e.g. *abot, *abouth, *abour or *qountity, *quantiny, *quontitiy. In some cases, the misspelled word is semantically correct but is pragmatically wrong as in We would be extremly * graceful if they come or *Unite price is $\$ 25$ per T-shirt. Some spelling mistakes, e.g. *abot, *unfourtanetly, *beacues, * recieved, can be easily corrected using the spell checker and the email will be more professional. Some spelling mistakes might be more difficult to correct, e.g. *graceful, as they are not recognized by the spell checker so the learners must carefully read the email before sending it and learn how to use dictionaries to check the meaning of words.

Finally, learning relevant phrases and structures used in the language of orders, e.g. Please find attached, will make the emails sound more professional and learners will avoid mother tongue interference. Mother tongue interference can lead not only to syntactically or semantically incorrect sentences but to also culturally inappropriate ones such as Thank you for writing to us. Of course you will get a discount or and I am curios for information about discounts for bulk orders. Do you bave that possibility or not.

To conclude, the findings reveal the areas that the incidental sample group of language learners has difficulties in when trying to complete specific writing tasks of placing an order and replying to an order. Although the sample was incidental, students had had similar problems with the same task before the academic year $2017 / 2018$ and the error analysis results could be used to improve the teaching in the academic years to follow.

\section{Conclusion and Limitations of the study}

Error analysis is an important tool in foreign language teaching. It enables the teacher to identify and classify errors that the learners make and helps him deal more easily and more successfully with difficulties that the learners have. Error analysis helps the teacher (or the material designer) design the materials that best fit the learners' current stage on the path towards the mastery of a foreign language. It also provides the learners with the input that is relevant and needed at that stage. Using error analysis can help the teacher expand their own repertoire of teaching methods and use the most effective pedagogical practices. 
This study may be a suggestion for other teachers on how to improve their teaching practice and provide a new framework for error analysis/correction and treatment. It may also help them design and implement appropriate teaching materials to meet the needs of their own learners and to fix and fill the learners' gaps. When the teacher recognizes the nature of his learners' errors and their (possible) sources, it will positively affect his performance and help him fill current pedagogical demands. This study may also contribute to the limited literature on error analysis on the tertiary level.

The main limitations of the study are that no external and internal factors, which might negatively influence learners' language performance, were taken into consideration. The learner corpus, which was compiled for research purposes, is limited and evidence from a large corpus of written material would be more solid. A large corpus would provide a more comprehensive list of errors which could be representative of the entire student population at the specific faculty, for example. Finally, a longitudinal study could be undertaken to monitor the development of students' language competence during their studies.

\section{References}

Ancker, W. (2000). Errors and corrective feedback: updated theory and classroom practice. English Teaching Forum. 38(4), 20-24.

Anthony, L. (2010). AntConc (Version 3.2.1) [Computer Software]. Tokyo, Japan: Waseda University. Available from http://www.antlab.sci.waseda.ac.jp/

Brown, H. D. (2007). Principles of language teaching and learning (5th ed.). White Plains, NY: Pearson Longman.

Candling, R. B. (2001). Vocabulary and language teaching. New York: Longman Inc.

Chun, A. E., Day, R. R., Chenoweth, N. A., \& Luppescu, S. (1982). Errors, interaction, and correction: A study of native-nonnative conversations, TESOL Quarterly, 16 (4), 537-547. doi: 10.2307/3586471

Corder, S. P. (1981). Error analysis and interlanguage. Oxford: Oxford University Press.

Dulay, H., Burt, M., \& Krashen, S. (1982). Language two. Oxford: Oxford University Press. James, C. (2013). Errors in language learning and use: Exploring error analysis. Abingdon, Oxon, New York, NY: Routledge.

Londoño Vásquez, D. A. (2008). Error analysis in a written composition. Profile Issues in Teachers' Professional Development, (10), 135-146. Retrieved from http:/ /www.scielo.org.co/scielo.php?script=sci_arttext\&pid=S1657$07902008000200008 \& \operatorname{lng}=$ en\&tlng $=$ en

Olasehinde, M. O. (2002). Error analysis and remedial pedagogy. In S. T. Babatunde, \& D. S. Adeyanju (Eds.). Language, meaning and society. Ilorin: Itaytee Press and Publishing Co. 
Richards, J. C. (1971). A non-contrastive approach to error analysis. Paper presented the TESOL Convention, SanFrancisco, March 1970.

Salem, I. (2007). The lexico-grammatical continuum viewed through student error. ELT Journal, 61(3), 211-219. doi: 10.1093/elt/ccm028

Schmitt, N. (2000). Vocabulary in language teaching. Cambridge: Cambridge University Press. 


\title{
Building Croatian Accounting Terminology
}

\author{
MATEA FiLKo, ANA OStroŠKi ANIĆ \& ANA JEŽOVITA
}

\begin{abstract}
Struna, the Croatian national term bank, has been built at the Institute of Croatian Language and Linguistics since 2007 using a unique model of terminology work which brings together subject field experts on the one hand and language experts on the other. Struna is a freely available online resource (struna.ihjj.hr) that provides special field terminology in Croatian. Experts from more than 30 specialized domains have so far joined the Development of Croatian Special Field Terminology program (funded by the Croatian Science Foundation), the aim of which is to standardize the terminology of various special fields. In this paper, we will present the basic features of the Struna term bank, as well as give an outline of the terminology workflow and theoretical framework on which Struna is based, with the special emphasis on the ongoing project of building the Croatian accounting terminology.
\end{abstract}

Keywords: $\bullet$ accounting terminology $\bullet$ term bank $\bullet$ Croatian $\bullet$ LSP - Struna •

CORRESPONDENCE ADDRESS: Matea Filko, MA, Research Assistant, University of Zagreb, Faculty of Humanities and Social Sciences, I. Lučića 3, 10000 Zagreb, Croatia, e-mail: matea.filko@ffzg.hr. Ana Ostroški Anić, PhD, Postdoctoral Researcher, Institute of Croatian Language and Linguistics, Republike Austrije 16, 10000 Zagreb, Croatia, e-mail: aostrosk@ihjj.hr. Ana Ježovita, PhD, Assistant Professor, University of Zagreb, Faculty of Economics and Business, Trg Johna Kennedyja 6, 10000 Zagreb, Croatia, e-mail: ajezovita@efzg.hr. 


\section{$1 \quad$ Introduction}

Terminology is not only one of crucial elements in LSP courses, it is invaluable in the communication between field experts and it is also especially useful to language specialists, e.g. translators or proofreaders. Thus a national term bank offering multilingual terminological information is a particularly valuable resource.

Struna, the Croatian national term bank, has been built at the Institute of Croatian Language and Linguistics since 2007 using a unique model of terminology work which brings together subject field experts on the one hand and language experts on the other. Struna is a freely available online resource ${ }^{1}$ that provides special field terminology in Croatian with translational equivalents in other languages, mainly English, Latin, Italian, German and French. Experts from over 30 specialized domains have so far joined the Development of Croatian Special Field Terminology program (funded by the Croatian Science Foundation), the aim of which is to standardize the terminology of various special fields.

This paper presents the basic features of the Struna database, and gives an outline of the terminology workflow and theoretical framework on which Struna is based, with a focus on the ongoing project of building the Croatian accounting terminology. ${ }^{2}$ The relevance of term banks in LSP teaching and learning is also underlined.

\section{$2 \quad$ Struna}

Ever since the terminological work by Bogoslav Šulek and his Croatian-GermanItalian Dictionary of Scientific Terms (1874-1875), most terminology standardization activities in Croatia have largely been carried out through individual efforts initiated by enthusiastic domain experts and LSP teachers working at higher education institutions, who worked on developing terminological dictionaries of their particular domains (Brač, Bratanić \& Ostroški Anić, 2015). Terminological work carried out at a national level and implemented through the work of a leading language institution had been lacking until 2007 and the beginning of the

\footnotetext{
${ }^{1}$ Struna is available at struna.ihji.hr.

${ }^{2}$ More information about the project can be found at hrana.net.efzg.hr
} 
program the Development of the Croatian Special Field Terminology (known under its Croatian acronym Struna).

Struna is a program financed by the Croatian Science Foundation (HRZZ) and carried out at the Institute of Croatian Language and Linguistics, which was chosen to serve as the national coordinator. The main purpose of Struna is to standardize Croatian terminology of various professional domains and make it publicly available through a national term bank developed for this purpose. The broader objective of the program, however, was to establish a framework for a national terminology policy that would lead to a continued terminology work and lay the foundations for a more structured education in the field (Bratanic \& Ostroški Anić, 2013).

A terminology policy that would clearly define the activities of terminology planning and terminology standardization is in Croatia still only implicitly a part of the language policy, which has also not been formulated, and the implementation of which has been changing depending on the historical and political conditions. Considering the nonexistence of explicit guidelines carried out by a relevant terminology standardization body - only partially present in the work of the Croatian Standards Institute (HZN) -it was necessary to envisage communicative needs of potential stakeholders, and to carefully plan the standardization activities that were to lead to the creation of a unified term bank.

As most normative term banks with the primary task of standardizing terminology, Struna was largely based on the traditional terminological premises set out in the work of Eugen Wüster and his followers. According to these terminological principles, codified in the ISO terminology standards, the terminology of a certain special field is defined as a structured group of concepts and their designations. Thus the model of the terminology standardization applied in Struna follows the semiotic principles as defined by this terminological tradition.

A firm methodological framework in the terminographic work within Struna was also necessary due to the specific nature of the cooperation between domain experts on the one hand of the process, and terminologists and linguists on the other. As opposed to a more common type of terminological collaboration in which experts perform the role of active consultants (Chiocchetti \& Ralli, 2013), domain experts working on terminological projects in Struna were given the role 
of the main stakeholders in the terminology standardization process. The experts are the ones compiling terminological entries, while the terminologists act as consultants and editors of the entries. A uniformed terminological description guarantees the consistency of terminology description. However, the diversity of domains and their conceptual structures, as well as the communicative needs of targeted users, have called for modifications and adjustments of the general terminological principles.

\subsection{Data categories in Struna}

The design of the work interface of Struna had to be as user friendly as possible since most domain experts working in Struna had little or no experience in lexicographic and terminographic work. The term bank is designed to serve both as an editing and storage tool, and a search and retrieval tool. It also has an integrated component of a terminology management system. In order to make Struna compatible and exchangeable with the existing term bases, its structure was designed in accordance with the TEI P5 guidelines for text markup and the TBX standard format for the representation and exchange of terminological data (Melby, 2015). The term bank's structure has been modified several times so far, primarily in terms of the number of data elements per record, as well as concerning its functional properties. The current list of record elements consists of the following data categories:

1. subject field and subfield

2. preferred Croatian term (simple and complex - i.e., multiword expression)

3. source of the term

4. foreign term language label

5. neologism label

6. interdisciplinary term label

7. grammatical information

8. definition

9. source of the definition

10. context

11. source of the context

12. synonyms - according to their normative status (admitted, proposed, deprecated, obsolete, colloquial) 
13. equivalents (English, German, French, Italian, Latin, Russian, etc.)

14. subordinate concept

15. antonym

16. abbreviation (Croatian and other languages)

17. symbol

18. formula

19. equation

20. hyperlink

21. picture

22. note

23. correspondence (chiefly among the domain editors, terminologists, and language experts).

Many new data categories have been introduced in the terminological entry since the first version of the database launched in 2009. Following the insight and user feedback from the first two rounds of terminology projects, the structure of the term bank has significantly been changed from its original monolingual perspective and its interface and performance improved to reflect the actual needs. Although it cannot be considered a proper translation oriented database, many of its features provide a thorough multilingual terminological description (Bratanić \& Ostroški Anić, 2015).

\section{Building Croatian Accounting Terminology}

Croatian accounting terminology has undergone numerous changes since the early 1990s, the International Financial Reporting Standards and the EU acqui communitare having the greatest impact on it (cf. Mamić Sačer, Pavić, \& Žager, 2018). Numerous changes in terminology cause communication problems and misunderstandings between field experts. Moreover, changes also cause immense problems when applied in legislation. Namely, terminological disagreements between different Croatian laws regarding the accounting business often make these laws inapplicable in practice. Therefore, it is crucial to resolve the existing terminological discrepancies, which is one of the primary goals of the project Building Croatian Accounting Terminology within the Struna term bank. During this project, most frequent Croatian terms from the domain of accounting will be analysed according to the methodology developed within Struna. The partners in the project are field experts from the Accounting Department of the Faculty of Economics and Business in Zagreb and language experts from the Institute of 
Croatian Language and Linguistics and the Linguistic Department of the Faculty of Humanities and Social Sciences in Zagreb. Apart from the standardization of the Croatian accounting terminology through the online Struna term bank, one of the intended results of the project is the glossary of the Croatian accounting terminology. This one-year project consists of several phases, which will be described in this chapter.

In the first phase, a referent corpus was collected and prepared. The corpus consisted of several subgroups of texts from the domain of accounting business. The first group of texts comprised national legislation and EU accounting directives. The second group consisted of International Financial Reporting Standards, globally accepted standards that had a large impact on the creation of the Croatian accounting regulation (Mamić Sačer, Pavić, \& Žager, 2018, p. 15), as well as the Croatian Financial Reporting Standards. The International Financial Reporting Standards are translated to Croatian and published in the official EU and Croatian publications. Both international and Croatian standards were available online and were easy to process and integrate into the project's corpus. The third group of texts included in the corpus consisted of the available high school and university level textbooks in the field of accounting, while the fourth group comprised the available literature published by the leading Croatian professional organizations in the respective field. In the end, the content of the web-sites of professional organizations and faculties of economics were also taken into account. The collected e-texts were then processed in Sketch Engine ${ }^{3}$, a language corpus management and query system, using available language tools for Croatian (e.g. tokenizer, lemmatizer, MSD tagger...). This enabled the extraction of the most frequent terms on the one hand and provided us with the examples of their usage on the other.

In the next phase, the extracted term candidates were manually checked by the high-skilled field experts participating in the project. The list of candidates was further expanded by the terms that had not been listed automatically, but were nevertheless essential in the accounting terminology. Finally, the list of 1500 most frequent terms was established to be added to the Struna term bank during the project. Since the Struna term bank is hierarchically organized, i.e. each concept

${ }^{3}$ https://www.sketchengine.eu/ 
is defined via its hypernym and distinguishing features, the extracted terms were organized into conceptual hierarchies in order to facilitate their processing.

The processing consists of several steps. In the first step, field experts add the concept and the recommended Croatian term via an online interface. Each concept is, besides the recommended Croatian term, followed by its definition and hyponyms, usage examples extracted from the corpus, other acceptable (synonymous) terms, and even non-recommended and archaic terms when they are available for the concept in question. Each Croatian term is accompanied by its English equivalent as well as equivalents in other languages if they are widely used. In the second and third step, a terminologist and a language specialist double-revise all terminological entries and discuss potential issues with field experts before making the database publicly available. Apart from simple spelling or orthography errors, the researchers working on the project came across different terminological issues, both professionally and linguistically related. Some of them will be discussed in the following sub-chapter.

\subsection{Croatian Accounting and Auditing Terminology - Discrepancies and Challenges}

Accounting is a technique of recording business events in accordance with the determined rules of the profession and the adopted set of accounting standards. The American Institute of Certified Public Accountants (AICPA) defines accounting as "the art of recording, classifying, and summarizing in a significant manner and in terms of money, transactions and events which are, in part at least of financial character, and interpreting the results thereof'. ${ }^{4}$ Adopting a certain set of accounting standards ensures profession's uniformity and enables comparability of accounting information. In that context, the International Financial Reporting Standards (IFRS) developed by the IFRS Foundation have a significant role in the European Union. The Foundation is the standard-setting body of the International Accounting Standards Board, whose mission is to enhance "transparency, accountability and efficiency to financial markets around the world. Our work serves the public interest by fostering trust, growth and long-term financial stability in the global economy." 5 Therefore, it could be considered that the accounting terminology is consistent and standardized.

\footnotetext{
4 https://www.aicpa.org/

${ }^{5}$ https://www.ifrs.org/
} 
Nevertheless, the Croatian language offers different alternatives for many accounting, and generally speaking, business terms. As stated above, the most troublesome is the fact that the terminology used in legislation is inconsistent, imposing unnecessary questions of correct choices and usage. Next to that, by a long-term practice, many fundamentally wrong terms become commonly used in science and profession.

For the purpose of this paper, we have compared several Croatian accounting terms with the corresponding English definitions found in most used online dictionaries. The definitions of the Croatian terms have been taken from the Croatian Language Portal $^{6}(\mathrm{HJP})$, and compared to the definitions in three English dictionaries (Oxford Dictionary (OD), Merriam Webster Dictionary (MWD), Cambridge Dictionary(CD)).

As it is defined, a report represents a spoken or written description of an event or situation (OD; CD), or a usually detailed description of an event or situation (MWD). As opposed to that, a statement is defined as a declaration of facts (MWD), a definite or clear expression of something (OD), or a formal and official list of financial details (CD). The corresponding Croatian terms should be izvješce for report and izvjestaj for statement. However, these two words of the same root are often considered as synonyms in general language. For example, the Croatian Language Portal defines izvješce as "a text that elaborates and describes more extensively the work of an institution over a given period". As can be noted, this definition of the Croatian word corresponds to the English term report and its definition in English dictionaries. However, iqvjestaj is not distinguished from izvješcé. It does not have a separate definition, but the entry iqvjestaj is linked to the entry izvješce. Although it is hard to distinguish between the two in general language, in specialized language the clear distinction can be made. Namely, if we talk about the balance sheet, income statement, cash flow statement, and others, we have to adopt the term financijski izvjestaji 'financial statements', while the term financijska iquješca 'financial reports' should be used in the case of more detailed disclosures and results of company's operations, e.g. an auditor's report or an annual report. This distinction should be clearly noted both in term banks, and in specialized and general language dictionaries.

\footnotetext{
${ }^{6}$ Hrvatski jezični portal, https://hjp.znanje.hr
} 
A similar explanation could be provided for the difference between terms revizorovo iæ̌jješce 'auditor's report' and revirijski iævjestaj 'audit statement'. Moreover, the term audit report, used by the European Parliament and the Council in the Directive 2014/56/EU and in the Regulation (EU) No 537/2014, is also incorrect. In accordance with the International Standards on Auditing ${ }^{7}$ that are in force for the Croatian companies obliged to conduct the financial statement audit, it is the auditor's responsibility to express an opinion, communicate key audit matters, disclose information on going concern assumption, and further on. In that context, an auditor is a person or an audit firm. Considering that, the most appropriate term is auditor's report, where the Croatian equivalent is revizorovo izvješce, or independent auditor's report, with the Croatian equivalent izvješce neovisnoga revizora. These terms emphasize that the report is the result of the financial statement audit (statutory audit), and not the result of internal audit engagements.

As opposed to that, when we are referring to a committee, the correct term is an audit committee (Croatian: odbor za reviziju) and not an auditor's committee (Croatian: revizorski odbor). The audit committee is a specialized sub-board of a supervisory board, whose members are directors and financial experts with the role of communicating with executive directors, internal and external (statutory) auditors on the financial questions and other matters prescribed by legislation (Tušek, 2007). Recognizing that the members of the committee are not auditors, the term auditor's committee has to be considered as inadequate, while the term audit committee and its Croatian equivalent revirijski odbor should be adopted.

Furthermore, Croatian language recognizes two terms related to the flow, namely tok and tijek, and correspondingly these two terms are used in relation to the cash flow. The first term, tok, is narrowly related to the direction of water movement in the nature, i.e. the natural flowing watercourse, or movement in space (HJP). The other term, tijek, relates to the moving in time, spreading, stretching and the way something develops or happens (HJP). By analysing general definitions of both terms, it is hard to conclude which one would be a better choice for adoption in the Croatian accounting terminology. However, if we narrowly associate the word tijek with time, and the word tok with space, it is adequate to use nov'ani tok as the equivalent of the English term cash flow. We consider money as a material object, not a temporal entity. The cash flow is therefore primarily

7 https://www.iaasb.org/ 
related to the cash movement between companies (space), and is only secondarily related to time (e.g. in financial statements during accounting period).

There are also other examples of misused terminology. It can often be read or heard that authors or speakers use the Croatian term related to the company's name - turtka - when they refer to a company and should be using the Croatian term poduzece instead. In accordance with the Croatian Company Act, the term tvrtka is the name of the company (Company Act, Article 11), and should not be used as a synonym for a company. Another example is related to the term dobit 'company's profit'. Namely, a certain number of authors and speakers use the term dobitak 'gain' when they talk about the difference between total revenues (income) and total expenses. The term dobitak 'gain' should be considered much wider, as an increase in size, weight, amount, value (OD, MWD, CD). Related to the accounting terminology, a gain is a component of the other comprehensive income that includes a transaction related to foreign operations, re-measuring available-for-sale financial assets, or hedging instruments in a cash flow hedge (Commission Regulation (EC) No 1126/2008). In addition to that, profit 'dobit', "is the total of income less expenses, excluding the components of other comprehensive income" (Commission Regulation (EC) No 1126/2008).

Apart from inadequate terminology, numerous alternative accounting terms can be found in Croatian. For example, poslovni dogadaj 'business event' and poslovna transakcija 'business transaction', poslovne knjige 'business books' and poslovne evidencije 'business records', revirija 'audit' and revidiranje 'auditing', umanjenje imovine 'impairment of assets' and vrijednosno uskladenje 'value adjustment', procjena 'estimates' and vrednovanje 'valuation', ispravak vrijednosti 'value correction' and akumulirana amortizacija 'accumulated depreciation and amortization'. In this project, we aim to list these cases and determine which of these terms are recommended for use both by field experts and linguists.

\section{The importance of term banks for LSP teaching and learning}

According to the developers of Struna, the most important goals of the term bank are 1) the standardization of Croatian LSP terminology, and 2) laying the foundations for a more structured education in the field of terminology and terminology planning (Bratanić \& Ostroški Anić, 2013, p. 676). Struna is primarily a national term bank, and therefore it can certainly be used to facilitate 
a monolingual LSP learning for Croatian students. Terminology is a major component of a specific segment of language that deals with specialized fields, i.e. language for special purposes (see Nagy, 2014, p. 262). LSP is characterized not only by specific terms, but also by specific knowledge (Nagy, 2014, p. 264), which is not "part of speakers' general knowledge; they are the object of a specific learning process" (Cabré, 1999, p. 65). Struna is thus particularly useful in LSP learning, since it offers field specific terminology, but, moreover, its hierarchical structure provides students with the complex knowledge structures of their respective specialized fields, accompanied by clear definitions and helpful notes and usage examples.

However, due to its structure, Struna can also be used in L2 LSP teaching and learning. As already stated above, each concept in Struna is linked to its recommended Croatian term and its equivalent in English, but often also by equivalents in other languages that are important for the respective field (e.g. French, German, Italian). This one-to-one relation between the Croatian term and the term in another language is especially important because the difference in vocabulary is the greatest difference between general language and LSP (Cabré, 1999, p. 73). Cabré (1999, p. 73) identifies three groups of lexical units in general language and LSP:

1. general language lexical units ${ }^{8}$, which are shared between general language and LSP, e.g. economy, risk,

2. lexical units which are in the borderline area between general language and LSP, e.g. receipt, customer,

3. lexical units which are LSP specific, e.g. accounting profit, multiphase divisional calculation.

Polysemy is particularly divergent in the borderline area between general language and LSP, and here it is important 1) to define the concept properly within the subject field, and 2) to determine the appropriate translational equivalent with regard to the corresponding sense. Struna offers both types of information and can thus be used as a valuable resource in L2 LSP teaching and learning.

\footnotetext{
8 Although Cabré uses the term lexical item, we prefer lexical unit instead.
} 


\section{$5 \quad$ Conclusion}

In this paper, we presented the program the Development of Croatian Special Field Terminology, the aim of which is to standardize the terminology of various special fields. We briefly presented the structure of the Croatian term bank Struna, which currently consists of the terminology of more than 30 specialized fields. However, the focus of the paper is on the ongoing project of building Croatian accounting terminology, through which we described the complex procedure of adding the terminology of one specialized field to the online Struna term bank. Some of the terminological issues raised during the project were discussed, as well as the importance of building term banks for LSP purposes.

\section{Acknowledgments}

This work has been fully supported by the Croatian Science Foundation under the project "Construction of Croatian Accounting Terminology" (Struna-2017-09-03).

\section{References}

Brač, I., Bratanić, M., \& Ostroški Anić, A. (2015). Hrvatsko nazivlje i nazivoslovlje od Šuleka do Strune - hrvatski jezik i terminološko planiranje. In M. Bratanić, I. Brač, \& B. Pritchard, (Eds.), Od Šuleka do Schengena: terminološki, terminografski i prijevodni aspekti jezika struke (pp. 3-26). Zagreb, Rijeka: Institut za hrvatski jezik i jezikoslovlje i Pomorski fakultet u Rijeci.

Bratanić, M. \& Ostroški Anić, A. (2013). The Croatian national termbank STRUNA: A new platform for terminological work. Collegium Antropologicum, 37(3), 677-683.

Bratanić, M., \& Ostroški Anić, A. (2015). Koncepcija i ustrojstvo terminološke baze Struna. In M. Bratanić, I. Brač, \& B. Pritchard, (Eds.), Od Šuleka do Schengena: terminoloskki, terminografski i prijevodni aspekti jezika struke (pp. 3-26). Zagreb, Rijeka: Institut za hrvatski jezik i jezikoslovlje i Pomorski fakultet u Rijeci.

Cabré, M. T. (1999). Terminology: theory, methods, and applications. Amsterdam/Philadelphia: John Benjamins Publishing Company. https://doi.org/10.1075/tlrp.1

Chiocchetti, E. \& Ralli, N. (Eds.). (2013). LISE Guidelines for collaborative legal/ administrative terminology work. Bolzano: Eurac Research.

Cambridge Dictionary (n.d.). Retrieved from https://dictionary.cambridge.org/

Commission Regulation (EC) No 1126/2008 of 3 November 2008 adopting certain international accounting standards in accordance with Regulation (EC) No 1606/2002 of the European Parliament and of the Council. Retrieved from https://eur-lex.europa.eu/legalcontent/EN/TXT/?uri=CELEX:02008R1126-20140101 [07/09/2018]

Company Act, Official Gazette number 111/93, 34/99, 121/99, 52/00, 118/03, 107/07, 146/08, 137/09, 125/11, 152/11, 111/12, 68/13, 110/15. Retrieved from https:// narodne-novine.nn.hr/

Directive 2014/56/EU of the European Parliament and of the Council of 16 April 2014 amending Directive 2006/43/EC on statutory audits of annual accounts and consolidated accounts. 
Retrieved from https://eur-lex.europa.eu/legalcontent/EN/TXT/?uri=CELEX:32014L0056

Hrvatski jezični portal. Retrieved from https://hjp.znanje.hr

Mamić Sačer, I., Pavić, I. \& Žager, L. (2018). Analysis of equality of principal accounting terminology in Croatian normative framework. In M. Ranjan Prusty, (Ed.) Proceedings of Researchfora International Conference (pp. 15-20). Bhububaneswar, India: Institute of Research and Journals.

Melby, A. K. (2015). TBX: A terminology exchange format for the translation and localization industry. In H. J. Kockaert, \& F. Steurs, (Eds.), Handbook of Terminology, Vol. 1. (pp. 392-423). Amsterdam/Philadelphia: John Benjamins. https://doi.org/10.1075/hot.1.tbx1

Merriam Webster Dictionary (n.d.). Retrieved from https://www.merriam-webster.com/

Nagy, I. K. (2014). English for special purposes: Specialized languages and problems of terminology. Acta Universitatis Sapientiae, Philologica, 6(2), 261-273.

Oxford Dictionary (n.d.). Retrieved from https://en.oxforddictionaries.com/

Regulation (EU) No 537/2014 of the European Parliament and of the Council of 16 April 2014 on specific requirements regarding statutory audit of public-interest entities and repealing Commission Decision 2005/909/EC. Retrieved from https://eurlex.europa.eu/legal-content/EN/TXT/?uri=CELEX:32014R0537 [07/09/2018]

The American Institute of Certified Public Accountants (AICPA). Retrieved from https://www.aicpa.org/

The International Auditing and Assurance Standards Board: The International Standards on Auditing. Retrieved from https://www.iaasb.org/

The IFRS Foundation. Retrieved from https://www.ifrs.org/

Tušek, B. (2007). Revizijski odbor u sustavu koroprativnog upravljanja, Economic Research - Ekonomska istrą̌ivanja, 20(2), 86-103. 


\title{
Die Rolle von Diagnosen im medizinischen
}

\section{Fachsprachenunterricht: Eine interdisziplinäre Analyse deutscher, österreichischer und ungarischer klinischer Diagnosen}

\author{
KATALIN FogARASI, PHILIPP SCHNEIDER \& ZOLTÁN PATONAI
}

\begin{abstract}
Zusammenfassung Die Anfertigung medizinischer Dokumentationen gehört zu den wichtigsten Fertigkeiten, über die MedizinerInnen bei der Ausübung der ärztlichen Tätigkeit verfügen müssen - sowohl in der Muttersprache als auch in der Fremdsprache. Innerhalb der Dokumentation spielen wiederum Diagnosen eine zentrale Rolle, da auf ihrer Grundlage die Finanzierung der Therapie sowie Überweisungen an weiterbehandelnde Ärzte erfolgen. Sie bilden die Entscheidungsgrundlage, auf welcher der Patient in die Behandlung einwilligt. Im vorliegenden Beitrag wird die Diagnosestellung in 51 deutschen, 37 österreichischen und 50 ungarischen Originalbefunden verglichen und analysiert, welche Unterschiede sich aus den verschiedenen kulturellen Traditionen ergeben und welchen Einfluss diese auf die Praxis haben. Die terminologische Untersuchung erfolgt aufgrund einer Konkordanzanalyse sowie einer statistischen Analyse, im Anschluss werden die Ergebnisse aus juristischer und medizinischer Sicht fachlich interpretiert. Zur Vorbereitung auf eine entsprechende berufliche Sozialisierung angehender MedizinerInnen in der Fremdsprache sollten diese Unterschiede im Rahmen des Fachsprachenunterrichtes thematisiert werden.
\end{abstract}

Schlüsselwörter: • Diagnosen • Medizinischer Fachsprachenunterricht Deutsch $\bullet$ Terminologie $\bullet$ Unfallchirurgie $\bullet$ Zivilrecht $\bullet$

\footnotetext{
ÜBer Den Autoren: Katalin Fogarasi PhD, Direktorin, Semmelweis Universität, Directorat für Sprachen und Kommunikation, Ferenc tér 15, 1094 Budapest, Ungarn, E-Mail: fogarasinuber.katalin@semmelweis-univ.hu. Philipp Schneider PhD. Ass. Jur. Risk, Payments \& Fraud Analyst, Eaton Gate Gaming, 00 Cambridge Grove, London, W6 0LE, Vereinigte Königreich Großbritannien und Nordirland, E-Mail: pmschneider@gmx.de. Zoltán Patonai, MD, Universität Pécs, Klinik für Traumatologie und Handchirurgie, Ifjúság útja 13, 7624, Pécs, Ungarn, E-Mail: zoltan.patonai@gmail.com.
} 


\section{$1 \quad$ Einleitung}

Die Bedeutung von Sprache, Sprachkompetenz und Spracherwerb bei der Aneignung genrespezifischen Wissens steht außer Frage - unabhängig davon, ob in der Muttersprache oder in einer Fremdsprache (Fluck, 1991: Vorwort; Schneider, 2015, S. 65). Insbesondere auch das Studium der Humanmedizin beinhaltet die Aneignung einer ganz eigenen Fachsprache, die gleich mehreren Anforderungen unterliegt: diese muss eindeutig genug sein, um bei den Beteiligten innerhalb der betroffenen Diskursgemeinschaft eine einheitliche Vorstellung von dem vorliegenden Krankheitsbild zu erzeugen, zugleich muss sie verständlich genug sein, den mündigen Patienten an seiner eigenen Behandlung angemessen teilhaben zu lassen. Darüber hinaus unterliegen ärztliche Kommunikation und Dokumentation zunehmend auch juristischen Vorgaben, sei es bei der Gewährleistung einer qualitätsvollen, mitunter arbeitsteiligen ärztlichen Tätigkeit, bei der Absicherung von Patientenrechten bis hin zur gerichtlichen Überprüfbarkeit des gesamten Behandlungsprozesses. Nirgendwo werden die hohen Anforderungen an das Erlernen medizinischer Fachsprache deutlicher als im Unterricht der medizinischen Fachsprache Deutsch mit nichtdeutschen Medizinstudenten, die unterschiedliche Sprachkompetenzen zwischen A2 und C1 in den Unterricht mitbringen. Nicht weniger wichtig ist aber auch die Vermittlung von Dokumentationskenntnissen an deutschsprachige Studierende der Medizin, die später in einem der deutschsprachigen Länder als authentische Mitglieder der ärztlichen Diskursgemeinschaft auftreten möchten.

Fachkenntnisse äußern sich fast in jedem Beruf durch Sprachkenntnisse und die Kenntnis der Genres eines Fachgebietes. Expertin oder Experte in seinem jeweiligen Fach wird man erst dadurch, „dass man die fachspezifischen Gegenstände und Sachverhalte mit fachspezifischem Erkenntnisziel, mit fachspezifischen Methoden in den Blick nimmt“. Dies geschieht in der Regel mithilfe von Sprache. Konkret bedeutet dies, dass man „im Lauf der Ausbildung die fachspezifische Terminologie, aber auch fachspezifische Textsorten und Diskursregeln rezeptiv kennen und selbst produktiv anzuwenden lernt" (Janich, 2010, S.10).

In Ungarn haben sich vor diesem Hintergrund Universitäten, die auch ausländische Studierende ausbilden, auf einen textsortenbasierten 
Fachsprachenunterricht spezialisiert. Mehrere Universitäten Ungarns bieten Studiengänge in englischer und deutscher Sprache an und bereiten ausländische Studierende auf eine spätere Berufsausübung in ihren Heimatländern vor.

In diesem Zusammenhang wurde ab 2010 an der Medizinischen und Juristischen Fakultät der Universität Pécs (Süd-Ungarn) ein textsortenbasierter Fachsprachenunterricht kontinuierlich eingeführt. Die Semmelweis Universität Budapest bietet seit 2018 eine noch breitere Palette an Fachsprachenkursen an (7 Sprachen), die sowohl ungarische als auch ausländische Studierende mit authentischen Textsorten in der Zielsprache vertraut machen. Der vorliegende interdisziplinäre Beitrag soll durch die Analyse von Diagnosen zeigen, welche Rolle authentische Textsorten in der Vermittlung der medizinischen Dokumentation spielen und wie wichtig die Thematisierung von Diagnosen im Unterricht der medizinischen Fachsprache Deutsch für ungarische Studierende sowie der medizinischen Terminologie für den deutschsprachigen Medizinstudiengang ist.

\subsection{Medizinische Dokumentation, Diagnosen}

Der Wortschatz der Medizin ist vergleichsweise groß und beinhaltet eine Vielzahl von Synonymen. Dies liegt vor allem daran, dass der Wortschatz auf nicht weniger als vier Hauptquellen beruht: Die Krankheitslehre leitet sich vor allem aus dem Griechischen ab, die anatomische Nomenklatur aus dem Lateinischen, forschungsintensive Gebiete wie die Immunologie übernehmen ihre Termini aus dem Englischen, alle häufig verwendeten Fachausdrücke haben zudem auch noch eine traditionelle deutsche Bezeichnung (Lippert, 1999, S. 1973). Vor diesem Hintergrund können sich die Lernenden nicht auf ihre bereits vorhandenen, mitunter exzellenten allgemeinsprachlichen Sprachkenntnisse verlassen, da viele allgemeinsprachliche Ausdrücke sowohl im medizinischen Kontext als auch in der konkreten Kommunikation mit dem ärztlichen Kollegen oder dem Patienten unpräzise, unangemessen oder gar falsch sein können (Fogarasi \& Schneider, 2015, S. 121). 


\subsection{Akademischer Anspruch bezüglich einer angemessenen medizinischen Dokumentation}

Über das bloße Erlernen eines die jeweilige Krankheit beschreibenden Wortschatzes muss es aber auch gelten, die Lernenden zu befähigen, die Fachsprache im jeweiligen Kontext angemessen zu verwenden und in die medizinische Dokumentation einzuführen. Dies gilt umso mehr, als dass es sich beim Patienten-Arzt-Verhältnis regelmäßig um eine privatrechtliche Beziehung handelt, bei der der Patient den Arzt für eine Leistung bezahlt und damit auch eine entsprechende Erwartungshaltung mitbringt. In der Arbeit mit Studierenden der Medizin fällt immer wieder auf, dass sich die Lernenden nur allzu gern auf ihre - vorhandenen oder nicht vorhandenen - Sprachkenntnisse verlassen und sich nur wenig Gedanken darüber machen, wie das von Ihnen Gesagte beim zahlenden - Patienten ankommt. Dies kann in zweierlei Hinsicht das Verhältnis zum "Kunden" Patient belasten:

\subsubsection{Der verwendete Wortschatz ist zu abstrakt}

Ein interessierter medizinischer Laie wird regelmäßig das Anliegen haben, die Ausführungen des Arztes, seien sie mündlich oder schriftlich, nachvollziehen zu können und gegebenenfalls Stichworte zu verinnerlichen, mit deren Hilfe er weitere Recherchen betreiben kann. Wenn selbst einfache Krankheitsbilder nur durch Fach- und Fremdwörter erklärt werden, wird dies beim Patienten womöglich auf Unverständnis stoßen, schlimmstenfalls auf Frustration. In jedem Fall ist damit dem auf Vertrauen beruhenden Arzt-Patienten-Verhältnis wenig geholfen.

\subsubsection{Der verwendete Wortschatz ist zu banal}

Im einen wie auch im anderen Falle wird ein Arzt von dem - ihn bezahlenden Patienten eben anders wahrgenommen werden, je nachdem, ob er bei der Kommunikation mit dem Patienten und/oder seinen Kollegen das angebrachte Wort verwendet. Im praktischen Fachsprachenunterricht geht es daher immer auch darum, den Lernenden ein Gefühl dafür zu vermitteln, welche Wörter im konkreten Kontext angebracht sind und welche für das Gegenüber möglicherweise unverständlich oder sogar befremdlich sind. 


\subsection{Rechtliche Pflicht zur angemessenen medizinischen Dokumentation}

Auch aus juristischer Sicht spielt der angemessene Umgang mit medizinischer Fachsprache nicht erst beim Aufklärungsgespräch anlässlich einer Patienteneinwilligung eine wichtige Rolle. In allen drei Ländern, Deutschland, Österreich und Ungarn gibt es darüber hinaus eine rechtliche Verpflichtung zur ärztlichen Dokumentation aller am Patienten vorgenommenen Untersuchungen und Therapien (Schneider, 2017, S. 21). In Deutschland ergibt sich diese unmittelbar aus dem im Zivilgesetzbuch geregelten Behandlungsvertrag mit dem Patienten, in Österreich und Ungarn ist die ärztliche Dokumentationspflicht in Spezialgesetzen niedergelegt (vgl. \630f deutsches BGB, \51 österreichisches Ärztegesetz und \$136 Gesetz CLIV/1997 über das ungarische Gesundheitswesen).

Neben der Pflicht zur grundsätzlichen Dokumentation regeln die Vorschriften in allen drei Ländern zugleich auch eine Auskunftspflicht gegenüber dem Patienten. Die Gesetzgeber wollten damit bewusst die jahrhundertealte Tradition der "privaten" Dokumentation zur "bloßen Gedankenstütze" durchbrechen und dem Patienten eine aktiver partizipierende Rolle in der Behandlung zugestehen. Denn nur "was dokumentiert [sei] lasse sich auch später noch nachvollziehen [und] die beste Dokumentation nütz[e] nichts, wenn die Akten für die [...] Patienten verschlossen blieben" (so etwa die Begründung des deutschen Gesetzentwurfs in BT-Drucksache 17/10488, S. 9ff). Dies versteht sich vor allem auch vor dem Hintergrund, dass der moderne Patient selbstbestimmter an seiner Behandlung teilhaben möchte und dass er sich die Möglichkeit offenhalten will, mit den zur Verfügung gestellten Unterlagen zu einem anderen Arzt oder gar vor Gericht gehen zu können.

\subsection{Anforderungen an eine ordnungsgemäße Dokumentation}

Vor dem Hintergrund einer rechtlichen Pflicht zur ärztlichen Dokumentation kann davon ausgegangen werden, dass der Arzt nicht einfach in beliebiger Weise dokumentieren darf, sondern dass er zur Erfüllung dieser Pflicht nach klaren Kriterien geordnete und gegliederte Krankenunterlagen erstellen muss. In der Praxis besteht eine Krankenakte aus einer Befunderhebung, der Diagnose und 
einem Arztbrief, in dem alle wichtigen Informationen an einen weiterbehandelnden Kollegen weitergegeben werden können. Für die behandelnde Tätigkeit an sich sind insbesondere die ersten beiden Dokumentationsformate von besonderer Bedeutung:

1.4.1 Im Rahmen einer Befunderhebung müssen alle relevanten Krankheitsbilder und Symptome, zumindest diejenigen, die einer therapeutischen Behandlung bedürfen, festgehalten werden. Hierzu gehört beispielsweise die genaue Lokalisation von Verletzungen, Aussagen zum Erscheinungsbild und zum Heilungsverlauf.

1.4.2 Die Diagnose wiederum muss zur Nachvollziehbarkeit der eingeschlagenen Therapie zumindest so genau gestellt werden, dass der Patient oder ein weiterbehandelnder Arzt eindeutig auf ein bestimmtes Krankheitsbild schließen und gegebenenfalls weitere Untersuchungen durchführen kann. Es genügt daher nicht, sich mit vagen oder allgemein gehaltenen Formulierungen um eine möglicherweise angreifbare Diagnose herum zu winden (vgl. Schneider, 2017, S. 538).

Der Diagnose kommt hierbei eine besonders hervorzuhebende Bedeutung zu, denn sie steht nicht nur psychologisch für den Patienten an zentraler Stelle, sie ist zudem auch der wesentliche Anknüpfungspunkt bei der Abrechnung mit der Krankenkasse oder etwa bei der grenzüberschreitenden Behandlung.

\subsection{Die medizinische Auffassung ärztlicher Diagnose}

Was unter einer Diagnose verstanden wird, geht aus der medizinischen Fachliteratur hervor. Die letzten Veröffentlichungen zu diesem Thema sind allerdings schon vor einigen Jahrzehnten erschienen. Das dazu in den 70-er Jahren veröffentlichte Fachbuch enthält in seiner letzten Ausgabe folgende Erklärungen: "Unter Diagnosensprache wird die Summe der pathoanatomischen Einzeldiagnosen bzw. deren Benennung verstanden“ (Höpker, 2014, S. 18). Eine genaue Definition ärztlicher Diagnose lautet: "Eine interventionsbezogene, operationale Informationsselektion" (Höpker, 2012, S. 18). Alle späteren Eingriffe beruhen ja auf der Diagnose, die als Ergebnis eines operationalen, von der Person des Diagnosestellers unabhängigen Prozesses, nach dem 
Ausschließen aller weiteren Möglichkeiten verfasst wird. (Höpker, 2012,18, S. 18) In Klassifikationen unterliegen Diagnosen hierarchischen Beziehungen.

\subsection{Diagnosen-Klassifikationen: z.B. ICD}

Diagnosen werden für statistische Zwecke klassifiziert, und als Diagnosekategorien behandelnden Ärzten weltweit zur Verfügung gestellt. Die International Classification of Diseases ist eine, von der WHO eingeführte, international geltende, standardisierte Klassifikation. Sie besteht aus 20 Kapiteln, die je nach Krankheitsgruppen alle Veränderungen und krankhaften Zustände umfassen. Die meisten Kapitel beruhen sowohl auf Englisch als auch in den Nationalsprachen auf der griechisch-lateinischen Terminologie. Eine Ausnahme bildet das Kapitel 19, das die Verletzungen thematisiert. Dieses enthält sowohl in der englischen Grundversion als auch in den übersetzten Versionen nationalsprachliche Termini (Fogarasi, Csongor, \& Schneider, 2018). Für statistische Zwecke ist es wichtig, die Diagnosekategorien möglichst allgemein zu halten, wie z.B. unter dem ICD-Code T13.1 die Diagnose „Offene Wunde der unteren Extremität, Höhe nicht näher bezeichnet". Es wird empfohlen, in manchen Fällen gleichzeitig mehrere Diagnosekategorien zu verschlüsseln, damit eine möglichst genaue Diagnose dokumentiert wird. Die Genauigkeit einer vom Arzt selber ausformulierten Diagnose wird allerdings meistens nicht gewährleistet (Fogarasi, Csongor \& Schneider, 2018).

\subsection{Untersuchungsgegenstand}

Die vorliegende Arbeit geht der Frage nach, ob es Unterschiede in der Formulierung von Diagnosen zwischen Deutschland, Österreich und Ungarn gibt, und wenn ja, welche.

Weiterhin wird untersucht, ob eventuelle Unterschiede zu berücksichtigen sind beim Unterrichten der medizinischen Terminologie für Studierende der Medizin im deutschsprachigen Studiengang und im Unterricht der medizinischen Fachsprache Deutsch für ungarische Studierende. 


\section{$2 \quad$ Material und Methoden}

Zu diesem Zweck wurde ein Bereich der Medizin ausgewählt, zu dessen ICDKodierung sowohl die ursprüngliche englische Version der ICD als auch ihre übersetzten Versionen nationale Termini verwenden: die Unfallchirurgie. Dadurch, dass im Falle von Verletzungen in den meisten Fällen Gerichtsverfahren eingeleitet werden, konnten nur authentische Befunde auf jeden Fall bereits abgeschlossener Gerichtsprozesse aus früheren Jahren analysiert werden. Die Diagnosen von 51 unfallchirurgischen Befunden aus Deutschland (Universitätsklinik Mainz, 2011), von 37 unfallchirurgischen Befunden aus Österreich (Gerichtliche Medizin Graz 2010-2014) und von 50 unfallchirurgischen Befunden aus der Universitätsklinik Pécs (2013-2015) wurden in anonymisierter Form analysiert.

Eine Konkordanzanalyse der Diagnosen wurde mit Hilfe von WordSmith 5.0 durchgeführt. Ergänzend wurde eine weitere manuelle, kontrastive terminologische Analyse und die statistische Auswertung der Daten vollzogen.

\section{$3 \quad$ Ergebnisse}

\subsection{Statistik der untersuchten Teilkorpora}

Tabelle 1: Statistik der untersuchten Korpora

\begin{tabular}{lccc} 
& $\begin{array}{l}\text { Ungarisches } \\
\text { Teilkorpus }\end{array}$ & $\begin{array}{l}\text { Österreichisches } \\
\text { Teilkorpus }\end{array}$ & $\begin{array}{l}\text { Deutsches } \\
\text { Teilkorpus }\end{array}$ \\
\hline $\begin{array}{l}\text { Anzahl der Befunde } \\
\begin{array}{l}\text { Anzahl der } \\
\text { dokumentierten }\end{array}\end{array}$ & 50 & 37 & 51 \\
$\begin{array}{l}\text { Verletzungen } \\
\text { Größen der }\end{array}$ & 141 & 137 & 68 \\
$\begin{array}{l}\text { Teilkorpora (n) } \\
\text { Types }\end{array}$ & 6601 & 4031 & 1891 \\
Tokens & 268 & 215 & 116 \\
& 1091 & 566 & 210
\end{tabular}

Obwohl das ungarische und das deutsche Teilkorpus fast die gleiche Anzahl von Befunden umfassten, enthielten die deutschen wesentlich weniger Diagnosen. Das österreichische Teilkorpus bestand hingegen aus deutlich weniger Befunden als die anderen Beiden, trotzdem umfasste es viel mehr Diagnosen als das 
deutsche Teilkorpus. Dieser proportionale Unterschied hat die Erstellung eines ausgewogenen Korpus deutlich erschwert.

3.2 Die Textsortenregeln in den drei Ländern bezüglich der Diagnosen von Verletzungen

Tabelle 2: Die verwendete Sprache in den Diagnosen der einzelnen Teilkorpora

\begin{tabular}{lccc} 
& $\begin{array}{l}\text { Ungarisches } \\
\text { Teilkorpus }\end{array}$ & $\begin{array}{l}\text { Österreichisches } \\
\text { Teilkorpus }\end{array}$ & $\begin{array}{l}\text { Deutsches } \\
\text { Teilkorpus }\end{array}$ \\
\hline Angabe von & $\begin{array}{c}\text { nur bei } \\
\text { ICD- Codes }\end{array}$ & $11 \%$ & nachträglich \\
ICD Kategorien & $\begin{array}{c}\text { Zwendiagnosen } \\
4 \%\end{array}$ & $40 \%$ & - \\
$\begin{array}{l}\text { Termini in der } \\
\text { Nationalsprache }\end{array}$ & $\begin{array}{c}82 \% \\
\text { (meistens }\end{array}$ & $10 \%$ & $79 \%$ \\
$\begin{array}{l}\text { zusätzlich) } \\
\text { Urmini gr.-lat. }\end{array}$ & $0 \%$ & $16 \%$ & $15 \%$ \\
$\begin{array}{l}\text { („eingedeutscht”) } \\
\text { Gr.-lat. Termini } \\
\text { in lateinischen } \\
\text { Konstruktionen }\end{array}$ & & & \\
\hline
\end{tabular}

ICD-Kodierungen wurden in den deutschen Befunden erst nachträglich, durch sog. Durchgangsärzte hinzugefügt. Die Verwendung von ICD-Kategorien statt vom Arzt selbst ausformulierter Diagnosen kam in den österreichischen Befunden am häufigsten vor. In den ungarischen Befunden wurden die Diagnosen (im Falle der Beteiligung der Ermittlungsbehörden) in 82\% sowohl auf Ungarisch als auch auf Lateinisch aufgeführt. Sowohl in den ungarischen als auch in den österreichischen Befunden war die Verwendung griechischlateinischer Termini typisch, die zu komplizierten Konstruktionen nach den Regeln der lateinischen Sprache zusammengefügt wurden. Ein zusätzliches Merkmal deutscher Befunde war, dass $82 \%$ handschriftlich erstellt wurden. 


\subsection{Unterschiede in der Verwendung von Termini}

Unterschiedliche Termini für die deutschsprachige Benennung von Riss-Quetschwunden wurden gefunden zwischen dem österreichischen und dem deutschen Teilkorpus. Weiterhin wurden Unterschiede in der lateinischen Terminusverwendung zwischen dem ungarischen und dem österreichischen Teilkorpus entdeckt: Riss-Quetschwunden und Stichwunden haben unterschiedliche lateinische Benennungen in Ungarn und in Österreich.

Tabelle 3: Unterschiedliche Termini für die gleichen Verletzungstypen in den Teilkorpora

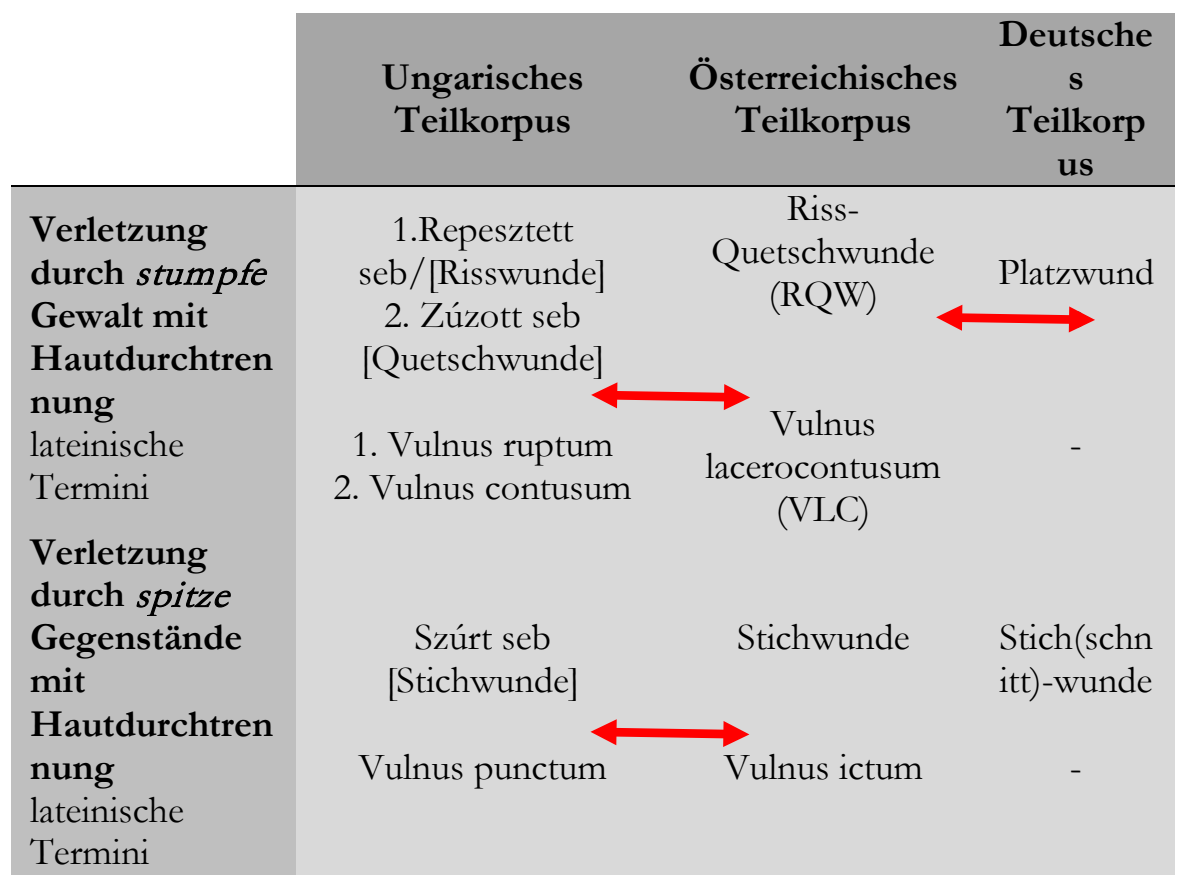

\subsection{Die häufigsten Termini in den einzelnen Teilkorpora}

Die häufigste Diagnose im ungarischen Teilkorpus war zúzódás (contusio) [Quetschung] ähnlich wie im österreichischen cont. [contusio]. Im Deutschen hingegen kam der Terminus Platzwunde am häufigsten vor. 


\subsection{Lokalisationen von Verletzungen in den Diagnosen}

Mit Hilfe der Konkordanzanalyse wurden die Lokalisierungen von Verletzungen untersucht. In allen drei Teilkorpora war die Lokalisierung unmittelbarer Teil der Diagnose. Im deutschen Teilkorpus wurde der Körperteil mit einer Abkürzung zur betroffenen Seite (re, li für rechts und links) in jedem Fall auf Deutsch angegeben. Eine häufige Verwendung von zusammengesetzten Formen konnte beobachtet werden z. B. hochfrontal, hochokzipital, aber auch als Komposita mit den Verletzungstypen z.B. Augenbrauenplatzwunde. Interessanterweise wurden unpaarigen Körperteilen ebenfalls Seiten zugeordnet: z.B. linke Stirn. Dieses Phänomen kam auch im österreichischen Teilkorpus vor, sogar auf Lateinisch z.B. nasi dext. [,,...auf der recbten Nase" ${ }^{\prime}$. Im ungarischen Teilkorpus waren die Lokalisierungen oft detaillierter und gaben die Seite bei unpaarigen Organen mit Hilfe von Umschreibungen an, z.B. orr, bal oldal [Nase, linke Seite].

\section{$4 \quad$ Zusammenfassung}

Die vorliegende Untersuchung fand Unterschiede in der Terminologie verschiedener Verletzungstypen zwischen den analysierten Teilkorpora. Diese Unterschiede zwischen den drei Ländern haben auch vorausgegangene, an anderen Korpora durchgeführte Studien ergeben (Fogarasi, 2012-2014, Fogarasi \& Schneider, 2015). Aus terminologischer Sicht können die im untersuchten Korpus in der gleichen Bedeutung verwendeten deutschen bzw. lateinischen Termini als vollständig äquivalent betrachtet werden. Auf der Benennungsebene kann die terminologische Äquivalenz laut einschlägiger Fachliteratur vorkommen, wenn in der Zielsprache die in der Ausgangssprache verwendete Wortart nicht existiert (Heltai, 1998 und Drößiger, 2007 in Fischer, 2010, S. 83). Bei diesen Termini ist dies nicht der Fall. Auf begrifflicher Ebene sind Termini in unterschiedlichen Sprachen als vollständig äquivalent zu betrachten, wenn die Merkmale der zwei Begriffe absolut identisch sind (Šarčević, 1990, S. 439). Vorausgegangene Studien haben ergeben, dass es sich um vollständige begriffliche Äquivalenzen handelt und die einzelnen Varianten als regionale Varianten aufzufassen sind (Fogarasi \& Schneider, 2015). 
Der Terminus Schnitt-Platzwunde im deutschen Teilkorpus war weder terminologisch noch aus medizinischer Sicht zuzuordnen: Nach dem Entstehungsmechanismus werden Schnittverletzungen durch schneidende Gegenstände verursacht, die parallel zu ihren Schneidekanten bewegt werden. Platzwunden hingegen entstehen durch stumpfe Gewalt, wenn diese den flexiblen Widerstand der Haut der darunter liegenden Gewebe überschreitet. Platzwunden können linear verlaufen, wenn sie durch Gegenstände stumpfer Oberfläche oder Schneidekante verursacht werden und die Haut entlang der Hautfelder aufreißt. Der Ausdruck Schnitt-Platzwunde kombiniert zwei gegensätzliche Entstehungsmechanismen, deshalb ist er irreführend.

Gerade bei der Übermittlung von Krankenunterlagen an die Kassen oder ins Ausland werden die Empfänger allerdings kaum die Befunderhebung näher in Augenschein nehmen, sie werden sich auf die übermittelten Diagnosen konzentrieren. Bei unterschiedlichen Termini für die gleichen Begriffe innerhalb derselben Sprache (lateinisch oder deutsch) zwischen zwei Ländern können leicht Missverständnisse entstehen. Es muss aber festgehalten werden, dass es auch in der medizinischen Terminologie regionale Unterschiede zwischen Ländern sogar innerhalb der gleichen Sprache geben kann. Die Ähnlichkeit zwischen den Ländern (z.B. Ungarn und Österreich in der Verwendung lateinischer Diagnosen) kann auf der gemeinsamen wissenschaftlich-kulturellen Entwicklung besonders zur k. u. k.Zeit beruhen, während diese kulturelle Prägung Österreich von Deutschland in einiger Hinsicht trotz der gemeinsamen Sprache unterscheidet (vgl. Tabelle 4).

Tabelle 4: Ähnlichkeiten und Unterschiede zwischen den Textsortenregeln bezüglich der Diagnosestellung

\section{Dokumentation von Diagnosen bei Verletzungen}

Ungarn Österreich

Deutschland

Trotz der unterschiedlichen Sprachen:

ähnliche Textsortenregeln (kulturell),

z.T. unterschiedliche Termini

Trotz der gemeinsamen Sprache: unterschiedliche

Textsortenregeln (kulturell),

z.T. unterschiedliche Termini 
Aufgrund der in der Einleitung ausgeführten juristischen Begründung kann festgehalten werden, dass eine richtige und genaue Diagnosestellung bei der medizinischen Dokumentation von höchster Relevanz ist. Deshalb gehört ihre Vermittlung sowohl beim fremdsprachlichen Fachsprachenunterricht als auch beim Terminologie-Unterricht zu den thematisierenden Grundkompetenzen. Die unterschiedliche Herangehensweise in Deutschland, Österreich und Ungarn hat Auswirkungen sowohl auf den medizinischen Fachsprachenunterricht Deutsch für ungarische Studierende als auch auf den Unterricht der medizinischen Terminologie für Studierende des deutschsprachigen Studiengangs. Zum einen müssen Studierende in beiden Kurstypen die unterschiedlichen Textsortenregeln kennen lernen und diese bewusst anwenden, zum anderen müssen sie befähigt werden, die in Österreich verwendeten lateinischen Konstruktionen bilden zu können. Dadurch, dass ungarische Studierende der Medizin die lateinische Diagnosestellung in Ungarn ohnehin gewohnt sind, müssen sie bei der Vermittlung der österreichischen Dokumentationsregeln anhand authentischer Befunde innerhalb des Fachsprachenunterrichts Deutsch nur auf die Unterschiede zum „Österreichischen Latein“ aufmerksam gemacht werden. Für die Gestaltung des Unterrichts der medizinischen Terminologie für deutschsprachige Studierende hat dies jedoch erhebliche Auswirkungen. Wenn eine gemischte Gruppe von Studierenden aus Österreich und Studierenden aus Deutschland den Unterricht besucht, muss differenziert vorgegangen werden: Österreichische Studierende müssen die Erstellung komplizierter Diagnosen in lateinischer Sprache vermittelt bekommen, während deutsche Studierende sie nur in ihrer Muttersprache lernen müssen. Auf regionale Unterschiede innerhalb des Deutschen müssen Studierende beider Herkunft aufmerksam gemacht werden. Dokumentationskenntnisse bilden einen unverzichtbaren Teil der fachlichen Sozialisierung und der Ausbildung einer fachlichen Identität innerhalb der medizinischen Diskursgesellschaft, deshalb müssen sie im Fachsprachenunterricht an jede Zielgruppe vermittelt werden. Nicht zuletzt werden dabei auch die interkulturellen Kompetenzen (Schön \& Schrimpf, 2010, S. 52) der Studierenden gefördert. 


\section{Literatur und Quellen}

Drößiger, H. H. (2007). Zum Problem der terminologisch-konzeptuellen Äkvivalenz zwischen zwei Sprach- und Kulturgemeinschaften: die sogenannten „Differenzen” zwischen den Sachen. Kalbotyra, Vol. 57. Nr. 3, S. 82-91.

Fischer, M. (2010). A fordító mint terminológus, különös tekintettel az európai uniós kontextusra. PhD Dissertation. Budapest: Eötvös Loránd Tudományegyetem.

Fluck, H. R. (1992). Didaktik der Fachsprachen: Aufgaben und Arbeitsfelder, Konzepte und Perspektiven im Sprachbereich Deutsch. Tübingen: Narr.

Fogarasi, K. (2012). Limited Forensic Assessability of Soft Tissue Injuries. Contrastive Terminological Analyses of Hungarian, Austrian and German Medical Diagnostic Reports. PhD Dissertation. Pécs: University of Pécs.

Fogarasi, K., Csongor, A. \& Schneider, P. (2018). Are ICD-10 categories suitable to diagnose injuries? The consequences of using terminologically vague or misleading diagnoses. In SDUTSJ (ed.) Scripta manent. 2018. (in press).

Fogarasi, K., \& Schneider, P. (2015). How the Incorrect Use of a Medical Genre and Terminology can result in Erroneous Legal Judgements. In Nacházíte se Centrum jazykového vzdělávání MU (Ed) CASALC Review, (S. 121-133). 2015-2016, (5/1) Brno.

Heltai, P. (1988). Contrastive Analysis of Terminological Systems and Bilingual Technical

International Organization for Standardization (2005) Terminology work - Vocabulary - Part 1: Theory and application. ISO 1087-1:2000. Abgerufen von: https://www.iso.org/obp/ui/\#iso:std:iso:1087:-1:ed-1:v1:en

Höpker, W. W. (2012). Das Problem der Diagnose und ibre operationale Darstellung in der Medizin. Berlin: Springer.

Janich, N. (2012). Fachsprache, Fachidentität und Verständigungskompetenz - zu einem spannungsreichen Verhältnis. Berufsbildung in Wissenschaft und Praxis (BWP) 41, H. 2: "Sprache und Beruf", S.10-13.

Lippert, H. (1999). Die Fachlexikographie der Medizin: eine Übersicht. In Hoffmann, L. u.a. (Hrsg.): Fachsprachen. Ein internationales Handbuch zur Fachsprachenforschung und Terminologiewissenschaft, Band 2. Berlin/New York: De Gruyter, S. 1966-1974.

Šarčević, S. (1990). Terminological Incongruency in legal dictionaries for translation. In Magay, T., \& Zigány, J. (Eds.) BudaLEX'88 Proceedings, (S. 439-446). Budapest.

Schneider, P. (2015). Die Einbettung von elektronischen Methoden und Fachtextsorten im juristischen Fachsprachenunterricht. In Backes, J. u.a. (Hrsg.): Jabrbuch der ungarischen Germanistik, 2015, Budapest. S. 65-83.

Schneider, P. (2017). Die klinisch-medizinische Dokumentation von vorsätzlichen Körperverletzungsdelikten durch stumpfe und scharfe Gewalt im Strafverfahren und die Folgen unzureichender Beschreibung und unpräziser Terminologie. PhD Dissertation. University of Pécs.

Schön, A. \& Schrimpf, U. (2010). Fachkommunikation in der Medizin - Konzeption und Durchführung von Kommunikationskursen und E-Learning im Bereich „Fachsprache Medizin“" mit interkulturellem Fokus“. German as a Foreign Language Journal, (1), (S. 49-70). Abgerufen von: https://gfl-journal.de/Issue_1_2010.php 


\title{
Business English or Survival English?
}

\author{
DRAGANA GAK
}

\begin{abstract}
Nowadays, the workforce worldwide is increasingly international with a frequent need to communicate in English with non-native speakers. People learning English for professional purposes range from pre-experienced students being familiar with only the hints about their future jobs to experienced professionals having difficulties to successfully and effortlessly participate in their daily activities due to lack of language knowledge. In recent years, much research has been carried out on international and intercultural business interactions attempting to give business English language teachers guidelines on how and what to teach to their learners. However, few studies have taken into consideration the fact that particular professional environments and specific industries influence immensely the way the language is used and the way the communication is established and maintained. The research and teaching practice need to be equally important in designing business English courses so that the courses and classes effectively and appropriately meet learners' specific language needs.
\end{abstract}

Keywords: • business English - communication skills • course designing • learners' specific language needs • international communication •

CORRESPONDENCE ADDRESS: Dragana Gak, Senior English Language Lecturer, University of Novi Sad, Faculty of Technical Sciences, Trg Dositeja Obradovića 6, Novi Sad 106314, Serbia, email:gak.dragana@gmail.com. 


\section{$1 \quad$ Introduction}

In the time of ever-growing globalization, English is the fastest-spreading language, and the implications, processes, and consequences of this phenomenon have been in the research focus over the past several decades (Sharifian, 2009; Holliday, 2005; Nakamura, 2002). The English language plays a crucial role in the rapid development of relationships between various communities and speakers of English around the world, empowerment of mobility and expansion of businesses. The workforce worldwide is increasingly international and has frequent need to communicate internationally mainly with non-native English speakers. Consequently, businesses, organizations and multinational companies have recognized the importance of using English as one communication language in the global context (Cogo, Archibald \& Jenkins, 2011).

As a result of this complex global process, teaching, learning and using Business English (BE) became ever more significant and challenging. Learners globally learn English out of economic necessity, to increase their chances of finding a new job, to keep their existing jobs or to get promoted and develop professionally. As a result, the roles of language teachers have changed and adapted to new circumstances. Instead of (just) teaching the language, teachers need to be knowledgeable about business issues and be able to design their $\mathrm{BE}$ courses so that they meet learners real needs adequately.

Bearing in mind that learners of $\mathrm{BE}$ operate in very demanding environments and that some of them enter the world of business with their level of language knowledge being very low, it is of great importance to understand their need for both language knowledge and effective practical communication skills. Additionally, it should be noted that due to the insufficient language knowledge, learners might perceive the language used in daily business-related activities as survival English, the language that helps them get by but at the same time makes them feel inadequately skilled and inferior to more fluent speakers of English. 
$\mathrm{BE}$ has been in the focus of researchers for decades now as one of the major and fastest growing areas of ESP. It is recognized as a unique type of English to teach and frequently described as an umbrella term for a mixture of general everyday English and general business English (Frendo, 2005). Since it has been researched from various perspectives, $\mathrm{BE}$ has contributions and insights coming not just from ESP but also from other disciplines, such as applied linguistics, sociolinguistics, intercultural communication, business studies, organization theory, corpus analysis, genre analysis, etc. All these different approaches help teachers analyze the real language and understand how professional genres work and how to use this knowledge when it comes to planning classes and designing effective courses.

Business English is understood differently by different people, and therefore it is hard to give one definition. The available definitions may be very detailed and thorough, such as:

Business English involves the teaching of the system of strategic communication in the social and economic domain of international business in which participants, adopting/adapting business conventions and procedures, make selective use of lexico-grammatical resources of English as well as visual and audio semiotic resources to achieve their communicative goals via the writing modality, speaking modality, and/or multi-modality. (Zhang, 2007)

On the other hand, they may focus on the fact that BE is all about "how people communicate using talk or writing in commercial organizations in order to get their work done" (Bargiela-Chiappini, Nickerson, \& Planken, 2007).

Regardless of definition, first and foremost, BE is focused on speakers' ability to communicate appropriately with other people to accomplish business aims, which on daily bases usually refer to buying, selling, negotiating, persuading, explaining, controlling, making arrangements, finding solutions to problems, etc. In order to understand these essential business-related activities, teachers need to be aware of the complexity of the context in which business communication happens. Furthermore, business communication is seen as the goal and contentoriented (Jenkins, Cogo \& Dewey, 2011) and the teachers need, up to certain 
extent, to identify the particular conventions for language use in specific domains of professional and occupational activity and have the domain-specific knowledge.

Moreover, to "survive" at work, apart from knowing the language, learners need to be well-informed about cultural aspects that are the inseparable part of the multilingual business environment in which business communication happens every time non-native speakers need to use English at work. In a multinational business environment, it is common practice to have several languages used and people coming from different linguistic and socio-cultural backgrounds. Fredriksson, Barner-Rasmussen and Piekkari (2006) use the notion "multilingual reality" to describe a typical business context and role of languages in the workplaces where professionals need at least two languages to do their work. Multiculturalism brings together a diverse set of cultural and linguistic backgrounds which consequently influence the use of English as a common communication language and the success of communication altogether.

\section{Learners and users of $\mathrm{BE}$}

When considering learners and speakers of $\mathrm{BE}$ in general, it is important to bear in mind the key aspects influencing the ultimate success of business communication. From the perspective of BE learners, whether they speak with native or non-native speakers and whether they are pre-experienced students or experienced professionals is of crucial importance.

Numerous articles and websites on the topic of native and non-native speakers of English begin with breakdowns of the total number of each of these groups. According to Heather Hansen (2018), a global communication specialist, there are 2.4 billion English speakers in the world and 2 billion of them learn English as a foreign language. As a result, global business English communication is carried out by speakers whose knowledge of English language ranges from barely knowing it and attempting to survive by using it to using the language at a very proficient level.

These numbers lead to the conclusion that most of the business communication happens among non-native speakers who do not live in a native English speaking environment and rarely come in contact with native English speakers (Alpetkin, 
2002). In such circumstances when the number of non-native speakers of English far outnumbers the number of native speakers of English, the question is raised whether native-like language is the goal learners need to strive for. Ehrenreich (2010, p. 418) points out that conformity with standard English is seen as a fairly irrelevant concept and that as long as the meaning is not distorted, $\mathrm{BE}$ speakers might not care whether something is correct or incorrect. In this new reality (Jenkins, 2011), the quality such as effectiveness in communication might be considered as a priority and the norms are established by its users instead of native speakers (Holliday, 2008, p. 122).

According to their professional experience, non-native speakers of English may be pre-experienced students or experienced professionals.

Generally, pre-experienced students or employees with very little working experience are either still studying about their future jobs and therefore are familiar with only the hints of what they might expect once they start working. In terms of the actual experience of real-life business context, they either do not have it or have insufficient on-the-job experience. In both cases, these business English learners need assistance and support with business concepts, development of intercultural awareness and language knowledge.

On the other hand, experienced professionals, although often being highachievers and excellent experts in their professional fields, have difficulties to successfully and effortlessly participate in their daily activities due to lack of language knowledge - for some of them an insurmountable obstacle. They have the first-hand experience of how difficult international business communication may be. If they are in a meeting, need to present in English, or do a small talk, instead of communicating successfully and confidently they might be struggling with expressing basic ideas and with the feeling of being disadvantaged because of their lower level of English proficiency.

Regardless of the working experience, language background and attitudes towards learning and using English at work, BE teachers need to be prepared for a variety of contexts and learning preferences. 


\section{$4 \quad$ Real-life teachers' experience}

Nowadays, teachers of BE work in a very dynamic context and need to be aware of numerous aspects related to both business and teaching, including recognizing and dealing with learners needs, their personal attitudes towards using the language and to the changes in the workplaces and technology.

The concept of teaching $\mathrm{BE}$ has gone through some major changes in the last several years caused by several developments, such as: developments in genre theory, awareness of the importance of combining classroom knowledge and business context, and the overwhelming use of new forms of media in the world of business. The genre theory has moved very much beyond what is offered by surface-level analyses of genres to incorporate in-depth analyses of the professional context. The gradual convergence of practice and theory made BE teachers realize that there is a need to bridge the gap between the academy and profession.

Like the majority of learners, the majority of BE teachers are non-native speakers and together with their learners belong to the group of 2 billion people worldwide who speak the English language as a foreign language. The advantage that they have is the fact that they themselves have been through the process of learning English and, as non-natives, know what it is like to learn the language. It is obvious for BE teachers and learners that communication is not simply a matter of putting words together in a grammatically correct and rhetorically coherent form, but more importantly, communication is also a matter of having the desired impact on the members of a discourse community, and understanding why they communicate the way they do. Additionally, the discipline-specific knowledge of how professionals conceptualize issues and talk about them in order to achieve their professional goals is crucial for developing effective communication skills.

In addition to understanding the work-related context, $\mathrm{BE}$ teachers must be aware of their learners as individuals, and be able to recognize not just their languages needs but also their attitudes towards learning the language. The most fundamental way of finding out what the learners' needs are is through the needs analysis. However, teachers describe that learners' reaction to needs analysis (NA) ranges from being surprised, having a vague idea on their goals to being genuinely interested in the process. The initial NA is the first chance to find out 
not only what the current knowledge level of the learners is, but also how they feel about speaking and using BE. Do they see it as a communication tool they are familiar with and comfortable using or is it a frightening reality they are coping with?

Learners' goals may vary greatly, from the most generalized ones, to be a more confident speaker and to communicate easier at work, to very specific ones related to an immediate future business situation. Their initial goals might be to help them get by and survive a business meeting, a presentation, small talk situation, etc. In this case, the learners frequently require a short and intensive course. However, eventually, as they start using the language more confidently, those goals shift towards being more able to participate in communication at a more challenging level.

\section{$4 \quad$ Conclusion}

In recent years, much research has been carried out on international business interactions attempting to give BE teachers guidelines on how and what to teach their learners. However, rarely these studies have taken into consideration the fact that particular professional environments and specific industries influence immensely the way the language is used and the way the communication is established and maintained and the fact that business English communication many times fails or succeeds based on how an individual person feels about speaking English for professional purposes.

After having taught BE both in academic and in-company contexts for more than fifteen years, my experience is that the key element is to understand the importance of helping learners learn the language they need to do their jobs effectively in English and prepare them for business communication both in terms of language knowledge and in terms of effective communication skills. Having this in mind, it is worth noting that classrooms and readymade textbooks might not be the best place to start learning BE. The real language of business meetings, presentations or phone calls can be very different from that taught in most traditional contexts. Therefore, creating a flexible, adaptable and accommodating environment for learning and practicing communication in English is of the utmost importance. 


\section{Acknowledgments}

The plenary talk is based on the bilateral project titled: Statistical Analysis of Business Correspondence from the Aspect of Students' Country of Origin. The project is supported by the Ministry of Education, Science and Sport of the Republic of Slovenia and the Ministry of Education, Science and Technological Development of the Republic of Serbia.

\section{References}

Alptekin, C. (2002). Towards intercultural communicative competence in ELT. ELT Journal. Vol. 56. Issue no. 1, pp. 57-64. doi:https://doi.org/10.1093/elt/56.1.57

Bargiela-Chiappini, F., Nickerson, C., \& Planken, B. (2007). Business discourse. Basingstoke: Palgrave Macmillan.

Cogo, A., Archibald, A., \& Jenkins, J. (2011). Introduction. In A. Archibald, A. Cogo, \& J. Jenkins (Eds.) Latest trends in ELF research (pp.1-7). Newcastle on Tyne: Cambridge Scholars Publishing.

Ehrenreich, S. (2010). English as a business lingua franca in a German multinational corporation: Meeting the challenge. Journal of Business Communication, 47, 408-431.

Fredriksson, R., Barner-Rasmussen, W., \&Piekkari, R. (2006). The multinational corporation as a multilingual organization: The notion of a common corporate language. Corporate Communications: An International Journal, 11, 406-426.

Frendo, E. (2005). How to teach business English. London: Pearson Education Limited.

Holliday, A. R. (2005). The struggle to teach English as an international language. Oxford: Oxford University Press.

Holliday, A. R. (2008). Standards of English and politics of inclusion. Language Teaching, $41,119-130$.

Jenkins, J.( 2011) Accommodating (to) ELF in the international university. Journal of Pragmatics, 43 (4), 926-936. doi:10.1016/j.pragma.2010.05.011

Jenkins, J., Cogo, A, \& Dewey, M. (2011). Review of developments in research into English as a lingua franca. Language Teaching, 44(3), 281-315. doi:10.1017/S0261444811000115

Nakamura, K. (2002). Cultivating global literacy through English as an International Language (EIL) education in Japan: A new paradigm for global education. International Education Journal. 3(5), 64-74.

Sharafian, F. (Ed.). (2009). English as an international language: Perspectives and pedagogical issues. Bristol: Multilingual Matters.

Zhang, Z. (2007). Towardsand integrated approach to teaching Business English: A Chinese experience. English for Specific Purposes, 26, 399-410. 


\title{
Die Beschreibung gegenwärtiger Beschwerden in Arztbriefen Analyse deutschsprachiger Formulierungsvorschläge in Musterarztbriefen
}

\author{
RENÁTA HALÁSZ, ZOLTÁN PATONAI \& KATALIN FOGARASI
}

Zusammenfassung Studierende werden im Medizinischen Fachsprachenunterricht Deutsch an der Medizinischen Fakultät der Universität Pécs auf die kommunikativen Situationen im späteren Beruf vorbereitet. Dies geschieht durch die Vermittlung aller wichtigen Fachtextsorten. Hierbei wird der Schwerpunkt unter anderem auch auf eine ausreichende Beherrschung der Textsortenregeln und des Wortschatzes in medizinischen Dokumentationen gelegt. Nach der Patientenbefragung, die der Erstellung der thematischen Einheit „Gegenwärtige Beschwerden“ in den Arztbriefen vorausgeht, müssen die erhobenen Informationen in deutschsprachigen Befunden mit Hilfe unterschiedlicher Formulierungsmuster erläutert werden. Selbst in der Muttersprache gehört die Kenntnis der in der schriftlichen Dokumentation gebräuchlichen Formulierungsweise zu den fachsprachlichen Kompetenzen praktizierender MedizinerInnen, obwohl diese keinen festgeschriebenen Regeln folgt, sondern tradiert wird. Viel erheblichere Unterschiede ergeben sich jedoch zur Fremdsprache, deren Formulierungsmuster aus anderen kulturellen Traditionen entspringen und dadurch auch unterschiedliche sprachliche Erscheinungsformen aufweisen. Eine entsprechende Beherrschung dieser Formulierungsmuster erleichtert angehenden Medizinern die fachliche Sozialisierung sowohl in der Muttersprache als auch in der Fremdsprache.

Schlüsselwörter: • Arztbriefe • gegenwärtige Beschwerden •
Fachphraseologie
Fachsprachenunterricht

ÜBer DEN Autoren: Renáta Halász, MA, LSP-instructor, University Pécs, Medical Faculty, Department of Languages for Specific Purposes, Szigeti Street 12, H-7624 Pécs, Ungarn, E-Mail: renata.halasz@aok.pte.hu, Zoltán Patonai, MD, Universität Pécs, Klinik für Traumatologie und Handchirurgie, Ifjúság útja 13, 7624, Pécs, Ungarn, E-Mail: zoltan.patonai@gmail.com. Katalin Fogarasi PhD, Direktorin, Semmelweis Universität, Directorat für Sprachen und Kommunikation, Ferenc tér 15, 1094 Budapest, Ungarn, E-Mail: fogarasi-nuber.katalin@semmelweis-univ.hu. 


\section{$1 \quad$ Einleitung}

Mündliche und schriftliche Fachkommunikation gelten als Kerngegenstände des Curriculums am Institut für Medizinische Fachsprachen und Kommunikation an der Universität Pécs, Ungarn und an der Semmelweis Universität Budapest. Nach sprachlichen Handlungssituationen, d.h. nach Textsorten werden diese Kommunikationsaufgaben in Kurse aufgeteilt, so können Studierende im Laufe des Studiums in frei gewählten Semestern Sprachkurse zur Anamneseerhebung, Patientenberatung, und zu Präsentationstechniken, usw. belegen.

Zur Natur des Fachsprachenunterrichtes gehört es, die Unterrichtsmaterialien ständig zu aktualisieren, Bedarfsanalysen durchzuführen und die Kursinhalte von Zeit zu Zeit zu erneuern (Kurtán, 2001), um neue Entwicklungen der Curriculumplanung identifizieren und wahrnehmen zu können. Nach unseren langjährigen Unterrichtserfahrungen sind wir der Auffassung, dass Inhalte, Materialien authentischer Quellen in den Fachsprachenkursen diskutiert werden müssen, seien es Kurse z.B. zur Anamneseerhebung oder zur schriftlichen Fachkommunikation. In unserem Beitrag möchten wir uns mit den MusterArztbriefen auseinandersetzen, die wir in den Kursen der schriftlichen Fachkommunikation einsetzen möchten.

\section{Musterarztbriefe im Fachsprachenunterricht}

Im Deutschunterricht für Studierende des allgemeinmedizinischen Studienganges wird der Kurs mit dem Titel „Einführung in die deutschsprachige schriftliche Fachkommunikation" angeboten. Für die Belegung des Kurses werden B2-C1 Sprachkenntnisse vorausgesetzt. Es handelt sich hier um einen Semesterkurs, in dem der Unterricht 14 Wochen lang mit je 2 Semesterwochenstunden stattfindet. Die Größe einer Gruppe beträgt maximal 15 Studierende aus allen Jahrgängen. Das Ziel des von uns konzipierten Kurses besteht darin, die Studierenden mit den wichtigsten Textsorten geschriebener medizinischer fachsprachlicher Kommunikation vertraut zu machen, wie z.B. Bewerbungen, Bestellungen, Schriftverkehr mit Dozenten, usw. Arztbriefe stellen einen wesentlichen Bestandteil der schriftlichen Fachkommunikation dar. Diese Textsorte wird auch von Muttersprachlern erst im Laufe der Berufssozialisation angeeignet, und dieser Lernprozess ist mit Schwierigkeiten verbunden: 
"Bemerkenswert ist, dass das Thema "Arztbrief" - gemessen an Bedeutung und Arbeitsaufwand - einen auffällig geringen Stellenwert in der ärztlichen Fachwelt sowie in Aus, Weiter- und Fortbildung hat. Das Verfassen von Arztbriefen ist als Lernziel weder im Medizinstudium noch in der ärztlichen Weiterbildung fester Bestandteil. " (Unnewehr, Schaaf, Friederichs, 2013). Die Verfasser des Artikels bemängeln, Leitlinien oder Empfehlungen von Fachgesellschaften zum Arztbrief gebe es nicht. Sie schlagen für die Entscheidungsträger vor, einen nationalen Lernzielkatalog für das Medizinstudium in Deutschland zu schaffen, in dem das „Schreiben oder Diktieren von Epikrisen/Arztbriefen" als Kernlernziel gefordert wird. Die Situation in Ungarn ist ähnlich. Gemäß unserer Untersuchungen wird das Schreiben von Arztbriefen auch bei uns in den Krankenhäusern und Kliniken durch hauseigene Tradition gelehrt und gelernt. Der Fremdsprachenunterricht kann hier seinen Beitrag zur Lehre in dem Sinne leisten, dass hier die Studenten die Möglichkeit haben, sich mit Musterarztbriefen zu befassen und parallel dazu auf ungarische Arztbriefe zu reflektieren.

Die Musterarztbriefe haben eine normierende Funktion und Wirkung. Als Handlungsanweisung bzw. -hilfe werden sie von Universitätskliniken, medizinischen Online - Plattformen und Foren konzipiert und zur Verfügung gestellt. Dadurch können sie im Fachsprachenunterricht als orientierende Normen beim Kennenlernen dieser speziellen Textsorte dienen.

\section{Die komplexe Behandlung von Musterarztbriefen}

Unser Ansatz ist die Vermittlung von fachsprachlichen Satzmustern, die für diese Textsorte der Fachsprache typisch sind und die Vertiefung von sprachlichen Mitteln, die zur Gestaltung dieser Inhalte dienen. Bei der Auseinandersetzung von Arztbriefen beschränken wir uns aber nicht nur auf sprachliche Inhalte. Auch fachliche, kommunikative und interkulturelle Bezüge werden im Kurs anhand der authentischen Unterrichtsmaterialien behandelt. Da für angehende Mediziner das Verfassen von Arztbriefen eine zu bewältigende Herausforderung darstellt und erst gelernt werden muss (Unnewehr, Schaaf \& Friederichs, 2013), spielt der Fachsprachenunterricht mit der kontrastiven Herangehensweise, d.h. mit der vergleichenden Untersuchung deutscher und ungarischer Arztbriefe bei der Aneignung dieser Fertigkeit eine wichtige Rolle. 
Wir halten es auch für wichtig, ungarische Medizinstudenten mit den interkulturellen Besonderheiten deutschsprachiger Arztbriefe vertraut zu machen. Die Globalisierung, studentische Migrationsmöglichkeiten und die wachsende kulturelle Diversität haben die Bedeutung der interkulturellen Ansätze auch in den Fachsprachenstunden gezeigt (Németh \& Kajos, 2014). Alle Kulturen haben ihre eigenen Ansichten zur medizinischen Betreuung und auch die damit verbundene schriftliche Festlegung des medizinischen Geschehens hat ihre Besonderheit. Sie ist Bestandteil der interkulturellen Kompetenz, die bei angehenden Ärzten besonders gefördert werden muss.

\subsection{Fachliche Inhalte im Fachdeutschunterricht Medizin}

Auch auf die fachlichen Inhalte der Arztbriefe muss kurz eingegangen werden. Es ist eine relevante Frage, ob die Lehrkräfte von Fachsprachenkursen über ausreichende Fachkompetenz verfügen, die es erlaubt, Arztbriefe, die einen sehr hohen Fachlichkeitsgrad aufweisen, zu behandeln.

Eine der wichtigsten Funktionen der Arztbriefe ist die Kommunikation zwischen Fachleuten mit sehr speziellem Fachwissen. (Halász \& Fogarasi, 2017). Wir schließen uns den Ansichten von Krekeler (2017) an, der sich auf die Aussagen von Ewer (1983) und Johns/Dudley-Evans (1980) bezieht: „Demnach können nicht nur Experten für das Fach, sondern auch Laien einen Fachsprachenunterricht erteilen, wenn sie die Struktur des Faches erfassen. Ein laienhaftes Interesse verbunden mit einem allgemeinen Überblick über das Fach und einem Verständnis für das Fach sind demnach binreichende Voraussetzungen für Planung und Durchführung von Fachsprachenunterricht. Lebrkräfte von Fachsprachenkursen können sich nicht auf ibre Rolle als Spracbvermittler beschränken; eine Auseinandersetzung mit dem Fach wird als erforderlich angesehen."

Bei der Planung unserer Kurse haben wir die einschlägige Fachliteratur und die Textsortenregeln des Arztbriefes berücksichtigt, die pragmatischen Funktionen eines Arztbriefes identifiziert, sowie uns ein Bild über die Anforderungen an die Arztbriefe von Seiten der Diskurs- und Handlungsgemeinschaft verschafft (Halász \& Fogarasi, 2018). Wir haben Interviews mit ÄrztInnen über den Lernprozess des Arztbriefschreibens geführt und möchten diese Arbeit noch fortsetzen. 
Die Musterarztbriefe stammen aus Leitlinien von Lehrkrankenhäusern und Kliniken und aus von Medizinstudenten genutzten Internet-Lernplattformen, sowie aus Sprachlehrmaterialien, die an Ärztinnen und Ärzte mit Migrationshintergrund gerichtet sind, die im deutschen Sprachraum arbeiten oder an deutschen medizinischen Fachsprachenkursen teilnehmen.

\section{(8)} $\triangle \mathrm{AMBOSS}$

Beispiel: Chirurgischer Entlassungsbrief eines Patienten mit akuter Appendizitis

Einleitung

Sehr geehrter Herr Dr. Hausmann,

im Folgenden berichten wir über unseren gemeinsamen Patienten

Herrn Max Mustermann, geb. 09.06.1984, wohnhaft in der Musterstraße 12, in 12345 Berlin,

der sich vom 31.07. bis 02.08.2013 in unserer stationären Behandlung befand.

Diagnosen

- Diagnose: Akute Appendizitis (K35.8)

- Therapie: 31.07.13 Appendektomie durch (Schlingen-)Ligatur, laparoskopisch (5-470.10)

\section{Anamnese}

Herr Muster stellte sich mit abdominellen Schmerzen in unserer Notaufnahme vor. Diese bestünden seit dem Vortag, beträfen den gesamten Bauch mit punctum maximum im rechten Unterbauch und seien von starker Übelkeit begleitet. Der Stuhlgang sei normal gewesen, möglicherweise habe leichtes Fieber bestanden.

\section{Körperlicher Untersuchungsbefund bei Aufnahme}

In der abdominellen Untersuchung fand sich eine leichte Abwehrspannung, ein deutlicher Druckschmerz über McBurney sowie ein kontralateraler Loslassschmerz. Die Peristaltik war regelrecht. Herz und Lunge o.p.B. $\square$

\section{Weitere Befunde}

Sonographie Abdomen bei Aufnahme: Leber und Gallenwege unauffällig. Pankreas normal konfiguriert. Milz unauffällig. Nieren unauffällig. Harnblase kaum gefüllt. Keine freie Flüssigkeit im Abdomen, im rechten Unterbauch starres flüssigkeitsgefülltes Darmsegment von $12 \mathrm{~mm}$ Durchmesser, welches nach kaudal medial in einem unübersichtlichem Konglomerat endet, wenig freie Flüssigkeit und echodichte Netzinfiltration in der Umgebung, sonst keine pathologische Magen-Darm-Kokarde erkennbar, kein Pleuraerguss bds. Beurteilung: Dringender Verdacht auf akute Appendizitis und perityphlitisches Infiltrat $q_{v}$

Labor bei Aufnahme: Blutbild: Hämoglobin (Hb): 152g/L, Hämatokrit: 0.44, Thrombozyten: 350/nL, Leukozyten: 14 000/uL; Gerinnung: INR: 1.00 , PTT: $28 \mathrm{sec}$, TPZ: $99 \%$

Abbildung 1: Beispiel für einen Musterarztbrief im Internet: AMBOSS - Fachwissen für Mediziner im ärztlichen Alltag und Studium [Online] https://www.amboss.com/de/wissen/Verfassen_eines_Arztbriefes

Die Leitlinien werden im Allgemeinen für Studierende im sechsten, im sog. praktischen Jahr verfasst. In Bezug auf die Inhalte dieser Arztbriefe kann Folgendes festgestellt werden: entweder werden nur die einzelnen Bestandteile eines Arztbriefes als Überschrift ohne Textinhalt angegeben, wie z. B. bei den Dokumenten des Universitätsklinikums Leipzig mit den Titeln ,ambulantes Briefmuster“ und „stationäres Briefmuster“ (Arbeitsmappe für PJ-Studenten, 2015). Hier werden Schlüsselwörter in bestimmter Reihenfolge als Vorlage zur Gliederung angegeben, wie „Diagnosen“, „Vorstellungsgrund“, „Anamnese“ usw. 
Andere Quellen liefern vollständige Arztbriefe mit konkreten Muster-Angaben (mit erfundenen, aber typischen Daten). Das Lehrwerk „Deutsch für Ärztinnen und Ärzte“ (Schrimpf \& Bahnemann, 2011) enthält z. B. einen vollständigen Muster-Entlassungsbrief.

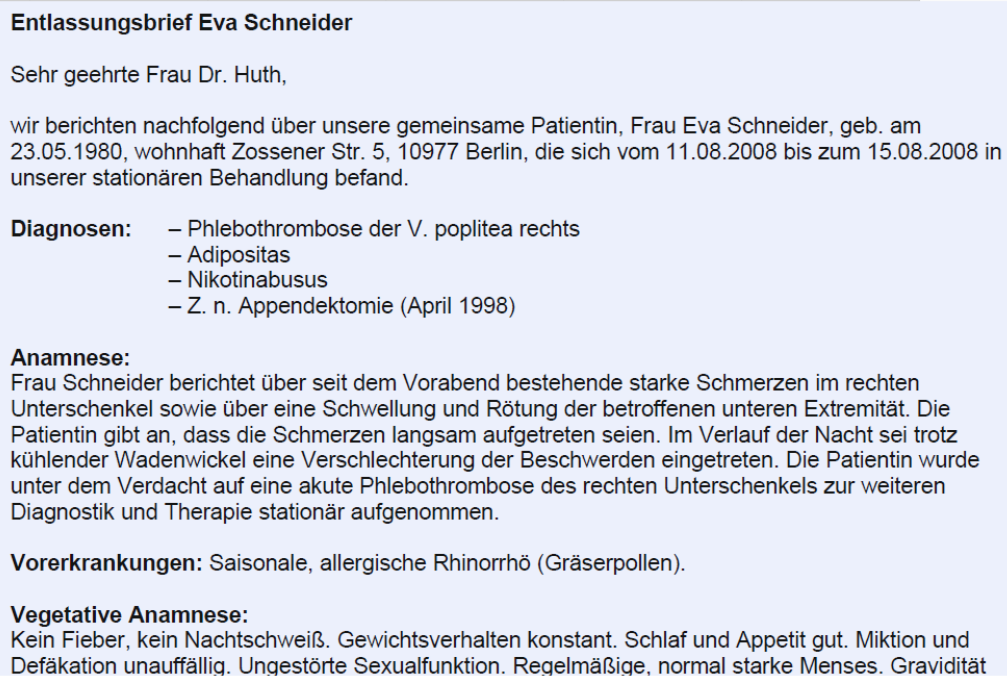

Abbildung 2: Beispiel für einen Musterarztbrief im Lehrwerk: Deutsch für Ärztinnen und Ärzte (2012)

\section{5 \\ Die Beschreibung ,gegenwärtiger Beschwerden“ in den Musterarztbriefen}

Arztbriefe sind „handlungsauslösende Dokumente mit über mehrere Ebenen hinwegreichenden Folgen“ (Bechmann, 2017). Die Verfasser müssen sich der rechtlichen Folgen der im Arztbrief erfassten Informationen bewusst sein (Schneider, 2017). Auch dieser Umstand führt dazu, dass die einzelnen Einheiten eines Arztbriefes auch im Fremdsprachenunterricht sehr genau unter die Lupe genommen werden müssen. Unklare Formulierungen können zu Missverständnissen, gar zu folgeschweren Fehlern führen. Die Textproduktion unterliegt nicht nur der Anforderung der Präzision; Aufbau und Formulierungen müssen der Tradition der jeweiligen Klinik, bzw. der ärztlichen Diskursgemeinschaft gerecht werden. Im Rahmen unserer Forschungen möchten wir die strukturellen Teile der Arztbriefe einzeln untersuchen und die 
relevanten Merkmale für den Fachsprachenunterricht erfassen. Im vorliegenden Beitrag wird die erste thematische Einheit analysiert.

Vorstellungsgrund und gegenwärtige Beschwerden bilden in den Musterarztbriefen eine besonders wichtige Einheit, denn diese beeinflussen die weiteren therapeutischen Maßnahmen. Im Rahmen dieses Beitrags konzentrieren wir uns auf die Schilderung der Beschwerden und Ursachen, die zu einem Krankenhausaufenthalt führten. In den von uns untersuchten Musterarztbriefen werden diese Informationen unter der Bezeichnung „Anamnese“ festgelegt. Aus 19 Musterarztbriefen haben wir die Anamnese-Teile herausgenommen und sie einer linguistischen Analyse unterzogen.

\subsection{Inhalte der Einheit „Anamnese“ in den Arztbriefen}

Bei den meisten Musterarztbriefen findet man auch Hinweise zu den inhaltlichen Anforderungen. Die Hinweise über den Inhalt der thematischen Einheit „Anamnese“ sprechen dafür, dass es keine einheitlichen Regelungen gibt. Zum Beispiel sollten laut der Anleitung von Böhmer (2016) folgende Inhalte in der Anamnese erfasst werden:

„An dieser Stelle gibst du die Art, die Dauer und den Verlauf der vom Patienten beschriebenen Beschwerden wieder. Dabei kannst du die Worte des Patienten verwenden. Risikofaktoren oder Vorerkrankungen, die im Kontext zu den aktuellen Beschwerden stehen, können ebenfalls erwähnt werden."(Böhmer, 2016).

https://www.thieme.de/viostatics/dokumente/vio-

2/final/de/dokumente/klinik/arztbrief.pdf)

Auf der von Medizinstudenten häufig genutzten Seite amboss.com stehen folgende Leitfragen zum Inhalt „aktueller Anamnese“:

(https://www.amboss.com/de/wissen/Verfassen_eines_Arztbriefes, Abruf: 09. 2018) 
- Vorstellungsgrund und Art der Vorstellung

- Mit welchen Symptomen stellte sich der Patient in der Rettungsstelle vor?

- Bei Einweisung durch einen niedergelassenen Arzt/Klinikambulanæ:Wer hat warum eingeniesen? / Bei Einlieferung mit dem Rettungswagen/Notarzt: Weshalb wurde der Rettungswagen gerufen? Wie wurde der Patient vorgefunden?

Folgende Textbeispiele aus Musterarztbriefen sprechen dafür, dass oft auch noch weitere Informationen, wie Untersuchungsbefunde in diesen Texten aufgeführt werden:

- Die stationäre Aufnahme des o.g. Patienten erfolgte am 11.11.2016 zur geplanten laparoskopischen Choleaystektomie bei symptomatischer Cholesystolithiasis. Mit dieser hatte sich der Patient zuvor in unserer allgemeinchirurgischen Sprechstunde vorgestellt. Sonographisch konnte im Vorfeld eine Cholesystholithiasis obne Hinweis auf Choledocholithiasis bei sonst unauffälligem Befund nachgewiesen werden. (amboss.com)

- Herr S. berichtete, am Morgen des 2.5.2008 sei es für ca. 30 Minuten zu einem Taubheitsgefübl der rechten Körperseite einschließlich des Gesichtes gekommen. An vaskulären Risikofaktoren bestehen eine langjährige arterielle Hypertonie und ein insulinpflicbtiger Diabetes mellitus. Aus der Vorgeschichte erwähnenswert sind eine Strumektomie 1998 bei Struma nodosa und ein Z.n. lumbalem Bandscheibenvorfall 2002. (In: Akademisches Lehrkrankenhaus der Universität Hamburg Neurologische Abteilung. Weiterbildungsordner für Assistenzärzte/innen. Anlage 8, Muster endgültiger Entlassungsbrief.)

- Aktuelle Anamnese: Seit ca. 4 Wochen zunehmende Belastungsdyspnoe (schon bei 3 Stufen), Schweregefühl in den Beinen und Abgeschlagenheit. In den letzten beiden Tagen habe die Atemnot auch obne körperliche Belastung zugenommen, vor allem im flachen Liegen, Patient schläft deshalb mit 2 Kopfkissen. Die Beine seien zwar schon immer etwas verdickt gewesen, bätten aber jetżt deutlich an Umfang zugenommen, die Schube würden nicht mehr passen. Leichte belastungsabhängige AP æ:B. beim Treppensteigen. Keine Palpitationen.

- Bek. Herzinsuffizienz und KHK (siehe Eigenanamnese) 
- (http://docplayer.org/50066281-Anleitung-zurerstellung-des-fallberichtes.html)

6.

\section{Aktuelle Anamnese:}

Am 26.11.2013 klagte die Patientin über akut aufgetretene Kopfschmerzen und Hemiparese links. Die Patientin wurde notfallmäßig im Krankenhaus Xxx vorgestellt. Computertomografisch zeigte sich eine rechtsseitige intrazerebrale Blutung mit Ventrikeleinbruch. Die notfallmäßige Schutzintubation erfolgte im primär versorgenden Krankenhaus XXX. Zur weiteren Therapie wurde die Patientin in unsere Klinik verlegt.

Oder

Die Patientin stellte sich am 26.11.2013 um 10 Uhr notfallmäßig mit plötzlich aufgetretenen Kopfschmerzen sowie einer linksseitigen Hemiparese im Krankenhaus XXX vor. Das durchgeführte $\mathrm{CT}$ des Schädels zeigte eine intrazerebrale Blutung rechts mit Ventrikeleinbruch. Anschließend wurde die Patientin als Schutzmaßnahme endotracheal intubiert. Zur weiteren Therapie nach der primăren Versorgung wurde die Patientin stationăr in unserer Klinik übernommen.

Abbildung 3: Beispiele für Musterformulierungen im Lehrwerk: Kommunikation für Ärztinnen und Ärzte. https://books.google.hu/books?isbn=3437182595 -

Anhand der zur Verfügung stehenden Musterarztbriefe kann festgestellt werden, dass die Inhalte der Anamneseteile variieren und nicht einheitlich aufgebaut sind. Neben Problemen, bzw. akuten Beschwerden, die als Vorstellungsgrund angegeben werden, und die mit Informationen über Beginn, Dauer, Intensität, Tendenz (Verbesserung/Verschlechterung) präzisiert werden, kommen in diesem Abschnitt auch Untersuchungsbefunde, Verdachtsdiagnosen und vorausgegangene Episoden, d. h. Angaben zu Vorerkrankungen vor.

Auch Hinweise für die Verfasser eines Arztbriefes in Bezug auf Ausführlichkeit und Formulierung beinhalten diese Leitlinien. Für die Deutsch lernenden Studierenden der Medizin sind diese unserer Auffassung nach auch von interkultureller Bedeutung. Ein Beispiel für die Hinweise an die Verfasser enthält folgende Ratschläge:

„Bitte kurz und präzise, alles Unwichtige weglassen; Konjunktiv benutzen bei Zitat des Patienten, objektive Daten im Indikativ!" (Anlage 8, Muster endgültiger Entlassungsbrief. Weiterbildungsordner für Assistenzärzte/-innen. 
Akademisches Lehrkrankenhaus der Universität Hamburg Neurologische Abteilung.)

\subsection{Ergebnisse der linguistischen Analyse der Einheit „Anamnese“}

Ziel unserer linguistischen Analyse war, im Sinne einer phraseologischen Untersuchung typische „Sprachfertigteile, Sprachmuster, Formel und Wendungen“ (Gréciano, 1993) zu identifizieren, deren Erlernen die Sprach- und Fachkompetenz der Studenten erhöhen. Zu den Fachsprachenkenntnissen gehören die pragmalinguistischen Kenntnisse der Lerner, die sich in Gebrauch der typischen Formulierungen in der richtigen Situation zu erkennen geben.

Häufige feste Wortverbindungen spielen eine wichtige Rolle im Unterricht von fremden Fachsprachen (Kispál, 2014 b). Damit Arztbriefe für den Fremdsprachenunterricht zugänglich gemacht werden können, haben wir die Mustertexte auf typische Formulierungen untersucht, die später in den studienbegleitenden Fachsprachenkursen bearbeitet werden können. Die Festigkeit einer Wortverbindung (nach Burger, 2010) bestimmt, ob die Formulierung als „typisch“ betrachtet wird. Die sich wiederholenden Kollokationen in unserem Korpus können als eine Basis für das Kursdesign betrachtet werden. Sowohl häufigere Wortverbindungen als auch feste, hoch idiomatische Phraseme bilden den Kern des Unterrichts. Da unsere Korpusanalyse auf 19 Mustertexten basiert, kann sie nicht als repräsentativ betrachtet werden. Doch können feste Wortverbindungen durch unsere Ergebnisse identifiziert werden, die auf statistisch-quantitativen KonkordanzUntersuchungen und unseren intuitiven Beurteilungen, sowie Unterrichtserfahrungen basieren.

Auf zwei Wegen haben wir die Struktur der Mustertexte erfasst: einerseits durch die Analyse der inhaltlichen Schwerpunkte der Formulierungshilfen, andererseits durch die Worthäufigkeitsanalyse. Inhaltlich haben wir uns auf die Hinweise der Musterarztbriefe und der einschlägigen Fachartikel verlassen, welche Informationen die Arztbriefe im Anamneseteil enthalten müssen. Demnach haben wir uns auf Aufnahmegrund / Vorstellungsgrund und Art der Vorstellung, aktuelle Beschwerden konzentriert. 
Die Bedeutung der Worthäufigkeitsanalyse ist bei Bornemann (2016) folgendermaßen beschrieben:

„Die Worthäufigkeitsanalyse ist eine Analysemethode der quantitativen Inhaltsanalyse mit Hilfe derer sich Wortmaterial binsichtlich bestimmter Aspekte, beispielsweise inhaltlicher Merkmale quantifizieren lässt. Ziel der quantitativen Inhaltsanalyse ist eine Zuordnung einzelner Teile eines Textes zu ausgewählten, übergreifenden Bedeutungseinheiten. Mittels der Häufigkeitsanalyse lassen sich Aussagen über bestimmte Merkmalsausprägungen des untersuchten Textes geben." (Bornemann, 2016). Die Autorin bezieht sich auf Bortz und Döring (2006) in ihrer Definition.

Die Größe unseres Korpus beträgt 1554 Wörter. Insgesamt wurden 104 Sätze untersucht. Die vorgenommene Worthäufigkeitsanalyse ergab folgende Ergebnisse: Zuerst haben wir untersucht, welche Wörter in der Häufigkeitsliste herausragen und welche Informationen sie inhaltlich zum Ausdruck bringen.

An den ersten 4 Stellen stehen im Korpus die Wörter „die, der, und, in“, die keine relevanten Informationen liefern. An fünfter Stelle steht das erste Substantiv „Patientin“ mit einer Häufigkeit von 26. Auch die Formen „Patient“ und „Patienten“ werden an Stellen 39 und 40 erwähnt, mit je 6 Vorkommnissen. An Stelle 8 kommt das nächste Substantiv „Aufnahme“ mit einer Häufigkeit von 14. Das dritthäufigste Substantiv ist „Beschwerden“ mit 10 Vorkommnissen. Das nächste inhaltlich eine wichtige Bedeutung tragende Wort ist „Schmerzen“ mit einer Häufigkeit von 6.

Diese Reihenfolge der häufigen Substantive entspricht unseren Erwartungen, denn gerade diese Wörter signalisieren die thematischen Einheiten des Anamneseteils.

Im Einzelnen ergibt die Analyse dieser Leitwörter folgende Ergebnisse:

Das Substantiv Patientin / Patient kommt in den Sätzen als Agent oder Objekt der Geschehnisse vor. Wir haben untersucht, mit welchen Kollokationen dieses Substantiv in den untersuchten Mustertexten einhergeht. In 39 Sätzen kommt das Wort Patient (Patientin, Patienten, Patientenangaben) vor. Da auch in den Anamneseberichten oft eine nominale Ausdrucksweise herrscht (vrgl. Gréciano, 
2007, die sich auch auf Kühtz, 2002 bezieht), sind Genitivkonstruktionen, wie „Aufnahme des Patienten“, bzw. „Einweisung der Patientin“ typisch. Sie zeugen von einem Nominalstil und deuten inhaltlich auf den Aufnahmegrund hin.

Mit der Präteritumform des Verbs „erfolgte“ bilden sie ein häufiges Formulierungsmuster:

- „Die stationäre Aufnabme erfolgte zur Abklärung und Behandlung stärkster Oberbauchschmerzen, ..."

- „die stationäre Aufnahme von Frau Morgenstern erfolgte bei thorakalen Schmerzen, die ..."

- „Die aktuelle stationäre Einweisung der Patientin des Patienten erfolgte mit Schmerzen im Epigastrium. "

Die Ursachen des Krankenhausaufenthaltes werden in den untersuchten Mustertexten mit folgenden weiteren Formulierungen angegeben:

- „zur Aufnahme führten ..."

- „wurde der Patient wegen einer ... beim ... vorstellig“

- „wurde mit Unterbauchschmerzen li. betont und Verstopfung stationär aufgenommen"

- „nehmen wir die Patientin, den Patienten zur geplanten Gummibandligaturanlage stationär auf"

- "die Patientin kommt zur Aufnabme"

- "stellte sich wegen ... vor"

- „stellte sich mit Fieber, produktivem Husten, ... vor"

Attribute, die das Wort „Aufnahme“ am häufigsten beschreiben, sind „stationäre“ oder ,aktuelle stationäre“, bzw. ,jetzige stationäre“.

In den untersuchten Texten gab es Beispiele dafür, dass die symptombezogene Begründung der Aufnahme neben der kausalen Präposition „wegen“ auch mit der Präposition „bei" ausgedrückt wird, wie es von uns auch schon bei den klinischen Arztbriefen beobachtet wurde (Halász \& Fogarasi, 2018). 
Zur Rolle von „bei" als ursächliche Angabe muss allerdings die Bemerkung gemacht werden, dass Bechmann (2017) in seinem Aufsatz gerade die Rolle von

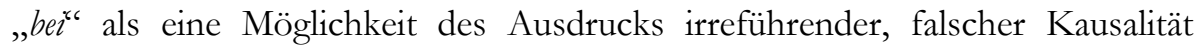
bezeichnet, wo er über sprachliche Fehler in Arztbriefen spricht. Sein Beispiel lautet: „Pneumonie bei Candida-Nachweis“ Er stellt die Frage, wie eigentlich diese Aussage gedeutet werden muss: „durch Candida oder mit Candida?"(S. 103).

Informationsdichte Formulierungen charakterisieren die Schilderung der Beschwerden, den nächsten wichtigen Inhaltspunkt. In vielen Mustertexten werden Schmerzen als Hauptbeschwerden beschrieben, wie es auch in der klinischen Praxis oft der Fall ist. Mehrere zusätzliche, präzisierende Angaben, wie z. B. Informationen über Schmerzqualität, Lokalisation, Beginn, bzw. Dauer und Auslöseursachen, sowie Tendenzen der Verbesserung oder der Verschlechterung differenzieren die Beschreibung der Symptome. Ein Satz enthält oft mindestens 4-5 Informationen über die geschilderten Beschwerden. 
1.

„Zur Aufnahme führten plötzlich aufgetretene kolikartige Beschwerden im rechten Oberbauch, die durch ... ausgelöst waren“"

Dauer / Schmerzqualität Symptome Lokalisation Auslöser

Beginn

2.

„klagte die Patientin auch nach kardiologisch-interventioneller Behandlung (PTCA, Stent) über immer wieder auftretende Brustschmerzen, verbunden mit starken Angstgefüblen" vorausgegangene Häufigkeit der Lokalisation BegleitTherapie Symptome Beschwerden

3.

„seit dem Vorabend bestehende starke Schmerzen im rechten Unterschenkel"

Dauer / Beginn Schmerzqualität Symptome Lokalisation

4.

„Zum Aufnahmezeitpunkt berichtet der Patient

über seit ca. 10 Tagen bestehende Schmerzen im Epigastrium mit zunehmender Tendenz"

Dauer/ Beginn Symptome Lokalisation Tendenz der

Beschwerden

\section{Abbildung 4: Beispiele für informationsdichte Musterformulierungen}

Die Präposition „mit“, die Adverbien einführt, spielt bei der Verwirklichung der Informationsdichte in vielen Beispieltexten eine wichtige Rolle. 
Weitere Beschwerden werden in den Texten mit folgenden Formulierungen angegeben:

- $\quad$ „Weiterbin klagte die Patientin “

- „Die Patientin berichtete, dass..."

- Außerdem bemerkte die Patientin ...“

- „Laut Patientenangaben ...“

Die Verwendung des Verbmodus und -tempus in den Arztbriefen ist auch von Bedeutung. Die Symptome werden entweder im Indikativ-Präteritum erzählt:

- „trat Fieber auf“

oder die Worte der PatientInnen werden im Konjunktiv wiedergegeben.

- $\quad$ „Bagl. Miktion und Defäkation bestünden keine Probleme.“

Das Wort „habe“ kommt mit einer Häufigkeit von 13 vor, „seit“ mit einer von 11, ,seien“ mit 6 Vorkommnissen.

- "Appetitlosigkeit bestanden babe“

- $\quad$ „er habe noch nie Probleme mit ..."

- $\quad$ „sei aufgewacht",

- _ _sei gekommen“

- _Der Appetit sei inzwischen wieder besser“

- _Beschwerden beim W asserlassen habe er nicht.“

Indikativ Präteritum wird bei der Mitteilung von Fakten verwendet. Wenn eine gewisse Distanzierung, neutrale Einstellung den vom Patienten Gehörten gegenüber gezeigt wird, wird Konjunktiv verwendet. In Bezug auf die früheren Symptome (zum Ausdruck der Vergangenheit) Konjunktiv Perfekt.

„Mediziner halten bei der Wiedergabe der von dem Patienten erbobenen aber nicht objektivierbaren Information von den Aussagen des Patienten explizit Abstand und bringen dies auch durch spracbliche Mittel zum Ausdruck. "(Halász \& Fogarasi, 2018) 
Verben in Konjunktivformen mit je einem Vorkommnis sind "bestünden", „beträfen“, „,מätten“ „,hätte“, „verspüre“, „würde“. Das Verb ,füble“ kommt zweimal im Korpus vor. Diese zeugen von der distanzschaffenden Formulierungsweise bei der Beschreibung der Beschwerden. Konjunktiv Plusquamperfekt könnte Zweifel an den Worten des Patienten ausdrücken, in den Musterarztbriefen haben wir aber keine Formulierungen in diesem Tempus gefunden.

Insgesamt sind es 8 Sätze, in denen die Präsens-Form der Verben, die inhaltlich auf aktuell bestehende (oder nicht bestehende) Beschwerden hinweisen können, vorkommen. Im Vergleich zu den insgesamt 30 Vorkommnissen von „habe“, „ser" und „seien“ kann man feststellen, dass im Anamneseteil die Geschehnisse oft im Konjunktiv beschrieben werden.

Nach diesen Struktur-signalisierenden Substantiven kommen Nomen, wie Fieber (5), Klinik (5), Therapie (5), Monaten (4), Tagen (4), Unrube (4), Behandlung (3), Einweisung (3), Familienanamnese (3), Stublgang (3), Abgeschlagenheit (2), Abklärung (2), Alkohol (2), Ängste (2), Angstgefüblen (2), Appetitlosigkeit (2), Aufnabmezeitpunkt (2), Belastungsdyspnoe (2), Defäkation (2), Diabetes (2), Durchschlafprobleme (2), Epigastrium (2), Episoden (2), Medikamente (2), Hinweis (2), usw. in der Häufigkeitsliste vor. In Klammern steht die Anzahl der Vorkommnisse im Korpus. Diese bezeichnen einerseits Symptome, Zeit- und Lokalisationsangaben, andererseits weisen sie auf Inhalte hin, die sich auf Therapie, Risikofaktoren, usw. beziehen, die auch Teil des Anamneseberichtes sein können.

\section{Didaktische Überlegungen zum Fachsprachenunterricht}

Bei den didaktischen Überlegungen lehnen wir uns an die Auffassung von Kispál (2014 a) an, indem wir davon ausgehen, dass die richtige Verwendung und kontextuelle Einbettung von wissenschaftssprachlichen lexikalischen Einheiten zur wissenschaftssprachlichen Kompetenz gehört. Der Kollokationsbegriff wird für den Unterricht im weiteren Sinne verstanden und auch polylexikalische grammatische Konstruktionen werden zu Kollokationen gerechnet. Auch wir sind der Meinung, dass die Einprägung von typischen Kollokationen aus didaktischen Gründen nützlicher sind, als die üblichen lexikographischen Zitationsformen der Wörter, wie z. B. Verben im Infinitiv oder Adverbien ohne Prädikat. Die Aneignung der speziellen Fachkenntnisse kann einerseits durch das rezeptive Kennenlernen der fachspezifischen Terminologie dieser Textsorte und 
der Diskursregeln (Janich, 2012) andererseits durch die produktive Benutzung der erlernten Formulierungen erfolgen. Kontrastive (deutsch-ungarische) Übersetzungen sowie nach Fallbeschreibungen gefertigte „Arztbrief“-Texte stellen die Aufgabenformen dar, in denen die erworbenen fachsprachlichen Kenntnisse produktiv anzuwenden sind.

„Nicht nur werden diese Kenntnisse benötigt, um sich überbaupt in einer facblich-funktional angemessenen Form über fachspezifisch interessierende Gegenstände und Sachverhalte verständigen zu können. Sie weisen auch diejenigen, die sie beherrschen, als Mitglieder einer Gemeinschaft von Expertinnen und Experten aus (...) Will man sich als kompetent erweisen, gebört es zur Wabrung des fachmännischen Images, nicht nur durch nichtsprachliches, sondern auch durch sprachliches Handeln zu zeigen, dass man sich in seinem Fach auskennt." JJanich, 2012).

\section{Literatur und Quellen}

Baethge, Ch. (2008). Die Sprachen der Medizin. Dtsch Arztebl 2008; 105(3): 37-40; DOI: 10.3238/arztebl.2008.0037

Bechmann, S. (2017). Die Sprache der Arztbriefe: Ethnomethodologische Ansätze in der Fachtextanalyse klinischer Arztbriefe. In Bechmann, S (Hg.) Sprache und Medizin. Forum für Fachsprachen-Forschung. Band138. Frank \& Timme. Berlin. S. 104.

Bergerová, H. (2011). Zum Lehren und Lernen von Phraseologismen im DaF-Studium. Überlegungen zu Inhalten und Methoden ihrer Vermittlung anhand eines Unterrichtsmodells. In Linguistik online Bd. 47, Nr. 3. URL: https://bop.unibe.ch/linguistikonline/article/view/365/563

Böhmer, S. (2016). So schreibt man einen Arztbrief. Abgerufen von: https://www.thieme.de/viamedici/klinik-medical-skills-praxisanleitungen1551/a/so-schreibt-man-einen-arztbrief-31852.htm

Bornemann, B. M. (2016). Dokumentationsbögen der Inneren Medizin und der Chirurgie für Anamnese und körperliche Untersuchung für die studentische Lebre in Deutschland: Eine Inhaltsund Strukturanalyse. Dissertation zum Erwerb des Doktorgrades der Medizin an der Medizinischen Fakultät der Ludwig-Maximilians-Universität München

Bortz, J. \& Döring, N. (2006). Quantitative Methoden der Datenerbebung in Forschungsmethoden und Evaluation. Springer. S. 137-293.]

Burger, H. (2010). Phraseologie. Eine Einführung am Beispiel des Deutschen. 4. Aufl. Berlin: Erich Schmidt.

Ewer, J. R. (1983). Teacher training for EST: problems and methods. In The ESP Journal, 2 (1), 9-31.

Farhan, N., \& Wirsching, M. (2017). Kommunikation für Ärztinnen und Ärzte. Vorbereitung auf die Fachsprachenprüfung und auf den Patientenkommunikationstest in Deutschland. Elsevier, München. 
Gréciano, G. (2007). Phraseme in mediæinischen Texten. In Burger, H. Dobrovol'skij, D. Kühn, P. \& Norrick, N. R. (Hrsg). Phraseologie. Handbücher zur Sprach- und Kommunikationswissensschaft. Band 28.1. De Gruyter, Berlin.

Halász, R. \& Fogarasi, K. (2018). Arztbriefe im medizinischen Fachsprachenunterricht Deutsch. JOURNAL OF LANGUAGES FOR SPECIFIC PURPOSES 5: S 87-102. Abgerufen von: http://jlsp.steconomiceuoradea.ro/current-issue/ (09. 2018) https://www.bibb.de/veroeffentlichungen/de/bwp/show/6857

Janich, N. (2012). Fachsprache, Fachidentität und Verständigungskompetenz - zu einem spannungsreichen Verbältnis. BIBB-Publikationen BWP 2/2012.

Johns, T. F. \& Dudley-Evans, A. (1980). An experiment in the team-teaching of overseas postgraduate students in transportation and plant biology. Team teaching in ESP. In ELT Documents 106. London: The British Council, S. 6-23.

Kispal, T. (2014). Kaffee oder Tee? Textkorpusbasierte Kollokationsforschung und ibre Realisierung in der Lernerlexikographie. In Bassola, P., Drewnowska-Vargáné, E., Kispál, T., Németh, J. \& Scheibl, Gy. (Hrsg.) Zugänge zum Text. Peter Lang Verlag. Frankfurt am Main.

Kispal, T. (2014a). Wissenschaftssprachliche Kollokationen in Seminararbeiten ausländischer Germanistikstudierender. Ferraresi, G., Liebner S. (Hg.) SprachBrückenBauen. Abgerufen von: http://www.kispaltamas.hu/files/Kispal_2014_Wissenschaftsspr_Kollokationen.pd $\mathrm{f}$

Krekeler, Ch., Harsch/Krings/Kühn (eds). (2017). Fachliche und sprachliche Inhalte im Fremdsprachenunterricht integrieren. Benötigen Lebrkeäfte Fachkenntnisse? Inhalt und Vielfalt - Neue Herausforderungen für das Sprachenlernen und -lehren an Hochschulen. Erträge des 5. Bremer Symposions, Fremdsprachen in Lehre und Forschung, 50, 2017, AKS-Verlag Bochum, S. 55-66.

Kühtz, St. (2002). Phraseologie in medizinischen Fachtexten. Wissenschaftliche Arbeit für die erste Staatsprüfung. Universität Saarbrücken.

Kurtán, Zs. (2001). Idegen nyelvi tantervek. Nemzeti Tankönyvkiadó Rt. Budapest

Nemeth T, Kajos A (2014) How to develop the intercultural competence of Hungarian students. PORTA LINGUA S. 155-164. Abgerufen von: http://szokoe.hu/kiadvanyok/porta-lingua-2014

Schneider, Ph. M. (2017) Die klinisch-medizinische Dokumentation von vorsätəlichen Körperverletzungsdelikten durch stumpfe und scharfe Gewalt im Strafverfahren und die Folgen unzureichender Beschreibung und unpräziser Terminologie. Abgerufen von: https://ajk.pte.hu/files/file/doktori-iskola/philipp-matthias-schneider/philippmatthias-schneider-vedes-ertekezes.pdf

Schrimpf, U. \& Bahnemann, M. (2012). Deutsch für Ärztinnen und Ärate. Kommunikationstraining für Klinik und Praxis. Springer-Verlag Berlin Heidelberg.

Trace, J., Hudson, T. \& Brown, J. B. (Eds.). (2015) Developing Courses in Languages for Specific Purposes.

Unnewehr, M., Schaaf, B. \& Friederichs, H. (2013). Arztbrief: Die Kommunikation optimieren. Dtsch Arztebl 2013; 110(37): Abgerufen von: https://www.aerzteblatt.de/archiv/145890/Arztbrief-Die-Kommunikationoptimieren 


\title{
InegMOOC - A MOOC on International Negotiations
}

\author{
GERHILD JANSER-Munro \& TANJA PSOnder
}

\begin{abstract}
Massive Open Online Courses (MOOCs) have been widespread in tertiary education since their advent in 2012 as they are considered to democratise education in so far as they provide access to it to a wider public. This paper briefly describes the development of a MOOC on international negotiations with the focus on the cultural dimension, negotiation strategies and legal issues. The chosen MOOC format is a four-week online course that addresses an approximate number of 50 bachelor's and master's degree students from different career fields as a group of predefined participants among other users. In the paper, the issues of course design that correspond to the demands of an online course, the preparation of e-tivities, the scope and the approach how to deal with the core and additional material are examined.
\end{abstract}

Keywords: $\bullet$ course design $\bullet$ e-tivities $\bullet$ implementation $\bullet$ MOOC development $\bullet$ negotiations $\bullet$

CORRESPONDENCE ADDRESS: Gerhild Janser-Munro, Mag. MBA, Lecturer, FH JOANNEUM UAS, Information Management, Eckertstraße 30i, 8020 Graz, Austria, e-mail: gerhild.jansermunro@fh-joanneum.at. Tanja Psonder, Dr, Lecturer, FH JOANNEUM UAS, Architecture \& Management, Alte Poststraße 154, 8020 Graz, Austria, e-mail: tanja.psonder@fh-joanneum.at. 


\section{The MOOC Concept}

The New York Times declared 2012 as 'the year of the MOOC' (Pappano, 2012). Since then, Massive Open Online Courses (MOOCs) in particular and online learning in general have made their world-wide impact on tertiary education as they provide open access to education and unlimited participation in a large variety of courses for everyone. Massive Open Online Courses are the interface between the well-structured and organised traditional classroom and the rather random World Wide Web. MOOCs integrate the basic concept of connectivism in so far that they facilitate expert knowledge and offer it to an undefined number of students who then define their individual learning goals and shape the course according to their prior knowledge and skills as well as their common interests. In other words, MOOCs are open for everyone in every respect; this also includes the open learning goals which can be tailored by the participant and the abundance of materials which allows the participant to select and choose from. In these complex educational eco-systems, the responsibilities are shared between the learner and the instructor. The instructor's responsibility is to provide the learner with adequate material that enables them to pursue their personal learning goals. In contrast, the learner's responsibility is to proactively participate in the course and perform in an autonomous way.

\section{The Research Questions}

This paper aims at analysing the content and process development of a MOOC in the field of international negotiations. Due to the instructors' years of teaching experience and their joint interest in innovative teaching approaches a traditional classroom was adapted and transferred into an online setting while three different and specific areas of negotiation-based interest were interwoven. The target audience was a predominantly heterogeneous in their study context and predefined student cohort supplemented by other learners who showed interest in this topic. The MOOC format in this respective context is defined as a fourweek online course that starts with an introductory week designed to help the participants socialise and immerse into the topic. The subsequent three weeks are each dedicated to the topics of (1) cultural dimension, (2) negotiation strategies and (3) legal issues. Each week is a self-contained session within the field of international negotiations. Hence, research question No 1 addresses the issue of course design in general, the scope of activities and how to deal with them in 
particular, while research question No 2 looks into the implementation and how to introduce the active online activities or e-tivities to the learners.

\subsection{The Course Design - Pre-requisites}

Massive Open Online Courses are a mass product of the connectivist theory that has marked the path towards new learning opportunities through the World Wide Web. People enrol in these online course, they learn together and share their results in this virtually connected community. Siemens (2012), one of the founding fathers of connectivism, characterises MOOCs as platforms that provide learners with this particular opportunity to build and construct their individual learning process. They work independently in their peer networks supported by e-facilitators and e-moderators when needed to answer their questions or to be guided through a demanding online learning activity.

According to Salmon (2018) online learners need to be supported through a structured process such as her five-stage-model that provides a scaffold for active online activities. The five-stage-model guides the learner through the online learning process starting at the early stage of access and motivation in which the e-moderator welcomes the participant. In the second stage, the learners experience the online socialisation, then proceed to the information exchange and eventually the active involvement into the provided e-tivities in addition to their co-operative communication tasks. Stage four is characterised by the knowledge construction as learners at this stage are ideally already in control of their own learning and are an integral part of the virtual learning community. In stage five, the learners are able to deploy their newly-acquired knowledge and present this knowledge if requested in various forms of assessment. Hence, learning in MOOCs is highly customised and peer connected at the same time.

Despite this relative liberty in online learning, the development of a Massive Open Online Course is focussed on the implementation of four key activities. These are:

- Aggregation;

- Remix;

- Repurposing;

- Feed-forward. 
In the material aggregation phase relevant presentation slides, lecture notes, and case studies are selected. The remix, then, is carried out in the form of online quizzes and assessment tasks. Interactive assessment, mock-up apps, as well as peer and self-assessment in order to modify and adapt the information to suit individual purposes form the characteristics of the repurposing process. Finally, the feed-forward process promotes the sharing of information with and learning from other participants. Discussion forums, blogs, twitter and even digital Kanban boards are used for these purposes. These four steps transferred into a basic didactical concept may result in a short and snappy video lecture preferably not longer than two minutes that introduces the topic and familiarises the online learners with the core content as well as related topics. This video lecture can be followed up by online assessment and a discussion forum.

Massive Open Online Courses take a considerable amount of time to create. The developers have to select an appropriate online platform that hosts the MOOC and guarantees the balance between the resources hosted on and off the platform. Videos and audio recordings even short in length take time to create and require certain technical skills of the developer. The selection and materials compilation phase equals a sequence of trial and error sessions that should include abundant buffer time to re-structure the activities and rephrase the tasks.

\subsubsection{E-tivities}

E-tivites are scaffolds that enable and support active and participative online learning. The concept clearly distances itself from the all-knowing instructor expert widely known from frontal teaching in the traditional classroom conveying the knowledge but in sharp contrast sees knowledge constructed by the peer group of learners. For this reason, e-tivities strongly depend on a highly significant title and a well-described purpose that is elaborated on in the task summary presented to the learners. This task summary is to be seen as an invitation to learning that should at the same time spark the fire of interest in the particular task and start the dialogue. The spark that sets the fire for a particular activity is comparable to a snappy video or an engaging audio message that attracts the online learners to look into the weekly tasks.

Transferring this concept into praxis results in a careful selection process of tasks and online activities. Not all activities present themselves to be applicable for 
online learning and, consequently, definitely need to be modified. Brief and very clear instructions that explain the task as to, what and how to do it are highly relevant. Instructor expectations such as the length and the form (e.g. continuous text, bullet points, etc.) of the contribution or where it is to be posted need to be specified by the e-facilitator and moderator in advance. Only this way the virtual learning community knows what to aim at. Online learning is also heavily dependent on clear communication structures that are well communicated to the group along with the individual activities and may be even repeated in the replies to the posts. Regular messages to motivate the learners as well as reminders to activate their learners' participation as in the following example are critical to guarantee the constant exchange between instructors and learners.

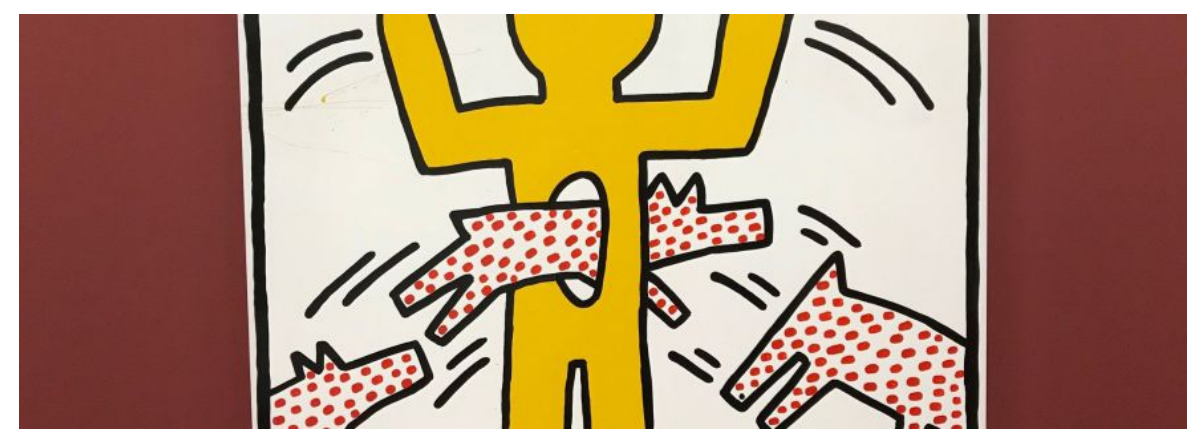

Figure 1: InegMOOC Reminder in Week 2 https://inegmooc.wordpress.com/

\section{Right in the middle of Week 2}

... and high time to find out how Trompenaars' \& Hampden-Turner's Cultural Factors differ from Geert Hofstede's 6-D Model of National Culture.

Please do not forget to choose a minimum of two assignments and to carry out the given tasks. So far, we have received 12 comments on Norine Dresser's Manners \& Gestures unit. Is Haole the same... Continue reading

In Massive Open Online courses, students are not guided through the course by their instructors but they are expected to self-organise their learning activities themselves. Neither are they left alone in their learning process as the efacilitators and in particular the e-moderators accompany them and react to their 
requests. Nonetheless, the learners heavily rely on clear instruction given in advance either in a written form or as a spoken message. In the InegMOOC, a short introductory video helps explain the course structure, introduces the participants' e-tivities and defines the learning outcome. Additionally, written instructions are added to serve both communication channels.

\subsection{Particular Implementation Features of the InegMOOC}

The InegMOOC was differently integrated into the curricular courses of the three involved degree programmes that formed the pre-defined student cohort. In one programme, it was fully embedded while in the other two degree programmes the MOOC was only partially embedded and supplemented by attendance times. Again in one of these two degree programmes with partial implementation, the InegMOOC was introduced in the form of a kick-off session and a pre-MOOC guideline was handed out to the student cohort. The awarding of badges worth 1 ECTS credit and the requirements for it were presented. Furthermore, as the online course forms part of the obligatory English language training in Universities of Applied Sciences in Austria error analysis standard procedures were specified.

\subsection{Basic Implementation Features of the InegMOOC}

In the detailed implementation of the active online activities, it has to be considered that only one skill is predominantly addressed in each MOOC content unit. Additionally, not more than three to five points should be raised in the individual tasks. The content units should be presented in a modular format devoted to this one particular skill with clear titles and instructions so that the students fully and unambiguously understand what is expected from them. Layout-wise, this can be supported by a clear content sequence which is displayed in each week to help the learners follow their continuous learning path.

Written instructions have to be explicit; this means the goal of the activity needs to be explained in detail as well as the time frame that is in advance calculated for the completion of the task. The participants also have to be informed about prerequisites such as preparative steps or additional material search. Both clear instructions as well as clear task descriptions that, when required, come along with a clear task sheet for the submissions are essential. The written instructions 
should be included into either a text lecture or be attached to a video lecture in the form of a pdf. In video instruction, the instructor has to choose an appropriate language and environment that attracts the participants to work on this activity.

As a last step in the learning loop, evaluation or feed forward options for the learners have to be provided. This could be an evaluation sheet or peer feedback using cloud-based options.

\section{$4 \quad$ Conclusions}

Conclusions can be drawn based on the student and instructor evaluation. In general, the outcome clearly differed between the three involved degree programmes. Nonetheless, a global student concern was the high number of audios, videos, obligatory texts and further reading in combination with the selection issue. Which e-tivities need to be chosen and how much reading would need to be done were the most frequently asked questions among others such as if the contribution need to be proof-read. The instructors were in general satisfied with the contributions in number and quality. In particular, some students posted highly remarkable comments and immersed themselves into the topic in so far as they provided the learning community with interesting book recommendations and cultural insights due to their bilingual upbringing and their experiences while staying abroad either in a professional or private context.

Concern that came from the instructors' side relates to the issue of availability as especially during the first week that is dedicated to socialising the e-moderators have to be virtually omnipresent to foster the socialising process and the regular exchange. One exceptional aspect that needs mentioning here is the feed-forward loop as at the beginning of the MOOC students responded more frequently to the e-facilitator and e-moderator than to the other participants. It obviously needed some time to accept the posts of the online learning community as source of information and support and to back away from the influences of all knowing instructors that also guide the learners through the tasks.

From a language instructor's perspective, the InegMOOC offered the learners a perfect setting in which they could use their written English in an informal context in their posts without any immediate instructor interference. This clear shift from the instructor's into a facilitator's and moderator's role who 
summarises the threads and stimulates pro-active contributions provided the learners with the possibility to explore their own learning approaches, gain more autonomy, to decide on their own learning behaviour and the way they used the foreign language actively.

\section{References}

Bremer, C. (2013). Massive Open Online Courses. In T. Knaus, \& O. Engel (Eds.), fraMediale - digitale Medien in Bildungseinricbtungen (pp. 30-48). München: Kopaed.

FutureLearn. (2018). Using FutureLearn. Retrieved September 13, 2018, from https://www.futurelearn.com/

Kim, S.-W. (2016). MOOCs in Higher Education. Retrieved October 10, 2018, from https://www.intechopen.com/books/virtual-learning/moocs-in-highereducation

Gilly Salmon Website. (2018). E-tivities. Retrieved October 4, 2018, from https://www.gillysalmon.com/e-tivities.html

Jordan, K. (2017). Initial Trends in Enrolment and Completion of Massive Open Online Courses. In International Review of Research in Open and Distance Learning. Retrieved October 4, 2018, from http://www.irrodl.org/index.php/irrodl/article/view/1651

Kop, R. (2011). The Challenges to Connectivist Learning on Open Online Networks: Learning Experiences during a Massive Open Online Course. In International Review of Research in Open and Distance Learning. Retrieved October 4, 2018, from http://www.irrodl.org/index.php/\%20irrodl/article/view/882/

Pappano, L. (2012). Education Life. The Year of the MOOC. In New York Times. Retrieved April 11, 2018, from https://www.nytimes.com/2012/11/04/education/edlife/massive-openonline-courses-are-multiplying-at-a-rapid-pace.html

Siemens, G. (2012). Massive Open Online Courses: Innovation in Education? In OER KnowledgeCloud. Retrieved October 10, 2018, from https://oerknowledgecloud.org/sites/oerknowledgecloud.org/files/pub_PS_O ER-IRP_CH1.pdf 


\title{
Factors of Successful Language Acquisition in Students of the University of Zagreb - Integrative and Instrumental Motivation
}

\author{
Ines JelovČić, Dubravka PleŠE \& Tina MiHOLJANČAN
}

\begin{abstract}
It has long been known that there are many different factors that play a significant part in the process of language acquisition. Motivation is, by far, the most significant among them. Faced with a large number of students each year we are always surprised to come across great differences that exist between learners of similar backgrounds. In our effort to discern the origins of such dissimilarities we decided to focus our research on the issue of motivation, specifically integrative and instrumental motivation, and see how they affect the success of language learning. We conducted our research on several groups of first year students from the Faculty of Mining, Geology and Petroleum Engineering and the Faculty of Humanities and Social Sciences, University of Zagreb. The students were presented with a questionnaire covering integrative and instrumental motivations for learning professional foreign language. The results of the survey are presented in this paper.
\end{abstract}

Keywords: - integrative motivation - instrumental motivation • language acquisition $\bullet$ professional language learning •

CORRESPONDENCE ADDRESS: Ines Jelovčić, M.A., Senior Lecturer, University of Zagreb, Faculty of Humanities and Social Sciences, Ivana Lučića 3, 10000 Zagreb, Croatia, e-mail: ijelovci@ffzzg.hr. Dubravka Pleše, PhD, Senior Lecturer, University of Zagreb, Faculty of Mining, Geology and Petroleum Engineering, Pierottijeva 6, 10000 Zagreb, Croatia, e-mail: dubravka.plese@gmail.com. Tina Miholjančan, B.A. in English and German, Senior Lecturer, University of Zagreb, Faculty of Humanities and Social Sciences, Ivana Lučića 3, 10000 Zagreb, Croatia, e-mail: tina.miholjancan@ffzg.hr. 


\section{$1 \quad$ Introduction}

Most language teachers will agree that motivation plays an essential role in the second language acquisition. Throughout their teaching careers they observe their students, analyse their classroom behaviour, monitor their progress and try to understand the reasons that move them forward to learn the language. Canadian social psychologist Gardner (1985, p. 10) defines motivation as "the extent to which the individual works or strives to learn the language because of a desire to do so and the satisfaction experienced in this activity". Gardner, who has researched the issue of motivation throughout his career, distinguishes between integrative and instrumental motivation. Integrative motivation is defined as the positive attitude towards the target culture and language and the desire and willingness to acquire the second language and assimilate into that culture. Instrumental motivation refers to utilitarian, functional reasons for learning such as passing a test, getting an employment, better career opportunities. Integrative motivation is also known as internal or intrinsic, aimed at personal development, while instrumental motivation is external and the reasons for language acquisition are more of pragmatic nature.

Gardner worked in a bilingual context in Canada while the environment in which Croatian students surveyed in this paper acquire English are monolingual and unicultural. Similar conditions of language acquisition were researched in Hungary (Clément, Dörnyei, \& Noels, 1994) where there was almost no personal contact with native speakers, however, the contact with English language and culture through the media and technology was substantial. Mihaljević Djigunović (1997) identifies three types of motivation among Croatian foreign language learners: pragmatic-communicative motivation of instrumental type with integrative elements, affective motivation and integrative motivation. The first refers to communication with native and non-native speakers as well as the assimilation into international community. The second is emotionally oriented towards liking English but without the expected correlation with the outstanding language performance and achievement. The third implies real integration into the target language community. However, the author also points out two demotivators for learning a foreign language: the teaching setting, which includes the teacher, materials and methodology, and learning difficulties. 
The aim of this paper is to discover students' attitudes towards the English language and to find out whether their reasons for learning professional language are more of internal and personal or external and utilitarian character. In other words, do the students enrol into professional language learning courses because their motivation is integrative, so they really want to master the language and make progress, or they are instrumentally motivated and do it because it is obligatory and they must pass the examination?

\section{$2 \quad$ Method}

In order to find out students' opinions, attitudes and motivation for professional language acquisition a questionnaire was created and distributed among students of the Faculty of Humanities and Social Sciences (HUM) and the Faculty of Mining, Geology and Petroleum Engineering (RGN) of the University of Zagreb. The questionnaire included three parts: the first required personal data about the student, the second offered statements about English language and language acquisition to rate and the third invited students to give their personal opinion about English.

The first part of the questionnaire collected personal data about the participants such as age, gender, language learning experience and grades in previous and present education. The sample included 256 participants, half of them, 128 students, studying at the Faculty of Humanities and Social Sciences of the University of Zagreb and the other 128 at the Faculty of Mining, Geology and Petroleum Engineering. Since they enrol into the course of English predominantly at their first year of pre-graduate studies, their average age was more or less the same, mostly nineteen. So, there was no significant difference among the respondents regarding the age. However, their gender was significantly different since a great majority of students, 108 participants of the research, at the Faculty of Humanities and Social Sciences were female $(84.38 \%)$ compared to only 20 male students (15.62\%) while at the Faculty of Mining, Geology and Petroleum Engineering the ratio between male and female students was not so prominently in favour of one gender: there were 76 male participants $(59.37 \%)$ versus 52 females (40.63\%). The starting age of learning English was more or less the same for all participants and it corresponded to the beginning of elementary school or included pre-school education in some cases. 


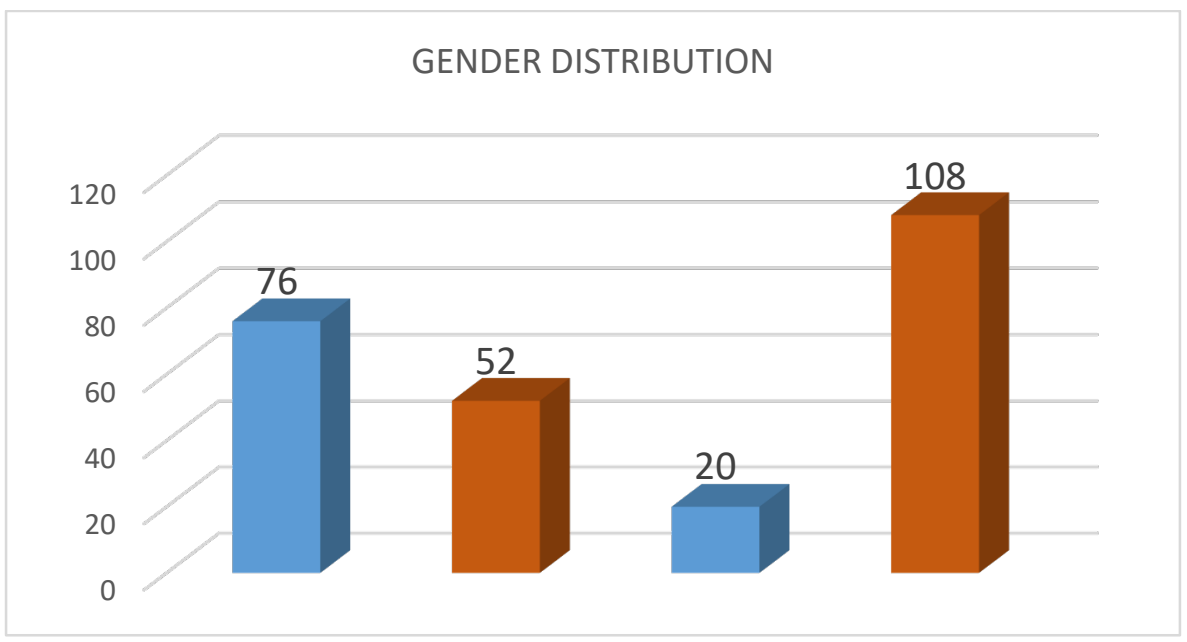

Figure 1: Gender distribution

In the second part of the questionnaire students were given statements about English and asked to rate them on the basis of 5-point Likert scale, the ranging scale which is "designed to measure people's attitudes, opinions, or perceptions" (https://www.britannica.com/topic/Likert-Scale). The scale ranked the statements from option 1 "completely agree" to 5 "strongly disagree". The statements regarding motivation were divided in two groups: the first referring to integrative motivation and the second to instrumental. Statements addressing students' integrative motivation were: 1) The knowledge of English is important for personal development, 2) I like reading books and magazines in English, 3) I like talking to strangers in English, 4) I would take English even if it were not an obligatory subject, 5) I frequently communicate in English on social networks. Instrumental motivation was tested through the following statements: 1) The knowledge of English is important for professional development, 2) I am learning English because of my family/environment, 3) English is the most frequently learned language in the world, 4) English is important in today's world, 5) English is the language of technologies.

The hypothesis was that the students of the Faculty of Mining, Geology or Petroleum Engineering will be more instrumentally motivated to learn English and that the motivation of the other group of students coming from the Faculty of Humanities and Social Sciences will, conversely, be mostly integrative. The reason behind this is our perception of engineering students as primarily oriented 
towards the acquisition of the professional knowledge and the development of technical skills. We assume that their motivation for language learning would be external and serve the purpose of achieving secondary, auxiliary skills in addition to basic, job-oriented ones. On the contrary, students of humanities are supposed to be oriented more towards a broad range of skills, including oral and written communication in different languages, critical thinking, cultural awareness, global affairs and similar issues. Generally speaking, integrative motivation seems to be stronger and thus more desirable, so we hoped both groups of students would result to be motivated in that way as much as possible.

\section{$3 \quad$ Findings}

\subsection{Integrative Motivation}

\subsubsection{The knowledge of English is important for personal development}

The results show that the students of the Faculty of Mining, Geology and Petroleum Engineering consider English important for their personal development (grade 4.41) more than the students of the Faculty of Humanities and Social Sciences (grade 4.17). Therefore, integrative motivation of students of technical sciences resulted to be stronger than in the students of humanities. Since literature, art, language, culture and social issues are a matter of both, personal and professional interest of the students of humanities and arts, the hypothesis was that the percentage of these students who consider English necessary for their personal development would be much higher and that the difference between them and the students of technical sciences would be more prominent. Thus, the opposite outcome was unexpected, even surprising. 


\section{THE KNOWLEDGE OF ENGLISH IS IMPORTANT FOR PERSONAL DEVELOPMENT}

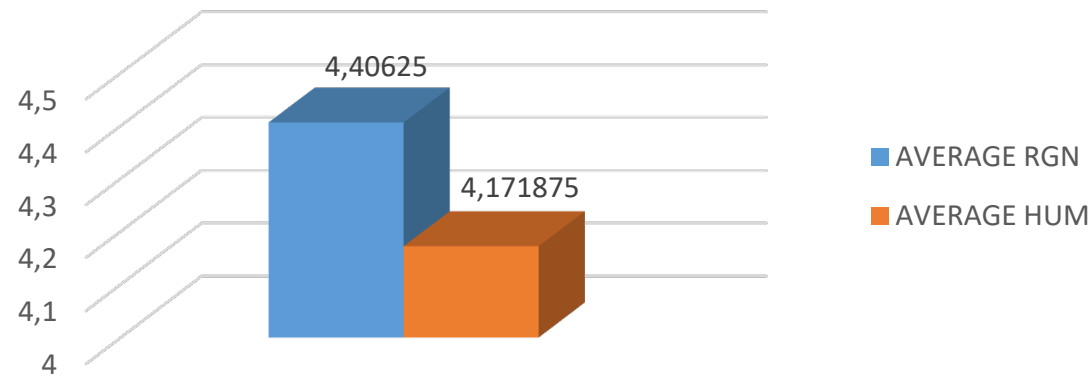

Figure 2: The knowledge of English is important for personal development

\subsubsection{I like reading books and magazines in English}

The result showed that the students of humanities and social sciences enjoy reading books and magazines more than the students of engineering. The grading of this statement showed a significant difference in favour of the students of humanities, 3.71, compared to 3.01 of the engineering students. It was quite a predictable outcome. Although the type of books and magazines was not specified, it can be supposed that, in answering this question, the students could have had the idea of reading fiction and popular magazines rather than professional literature. However, it must be pointed out that with students of language and literature it is their "job" to read fiction, a product of the author's imagination, and not only literary criticism and professional magazines written in formal, objective and impersonal academic style. But it must also be stressed that by frequent reading in the original language, regardless of the material in question, students improve their language skills and widen their knowledge of vocabulary, grammar and style, which is definitely useful for their successful mastery of professional materials as well. It can be understood from the words of one of the respondents, clearly the English language enthusiast: "I try to collect books originally written in English because I consider the style of my favourite authors beautiful and I always try to express myself using such language." This comment is an excellent illustration of how students' integrative motivation resulting from enjoying their favourite reading material can influence their linguistic progress and improvement. 


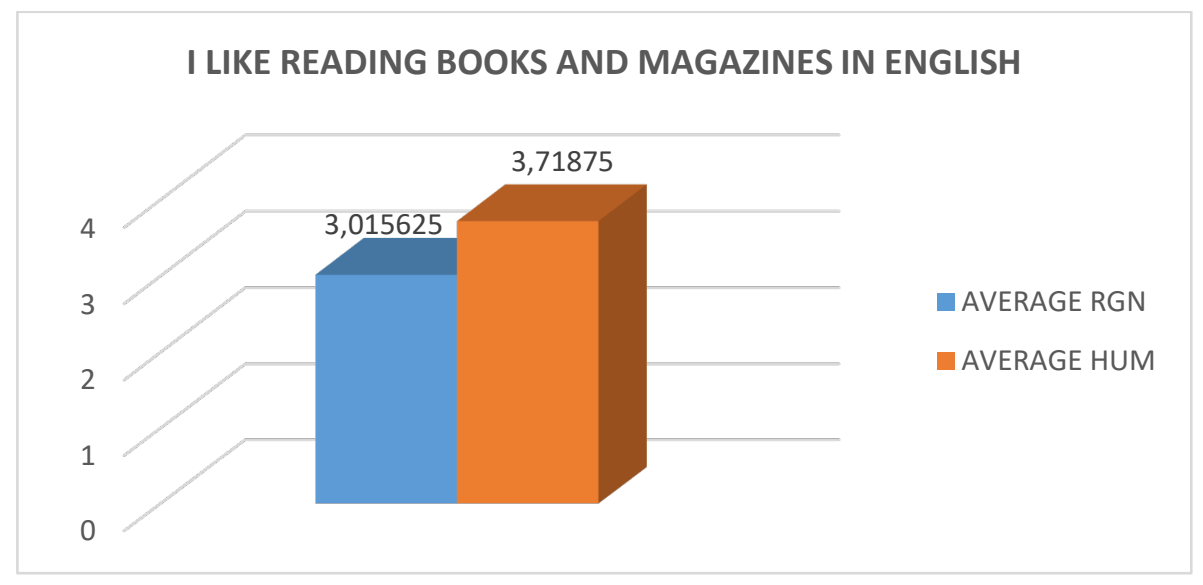

Figure 3: I like reading books and magazines in English

\subsubsection{I like talking to strangers in English}

More students of humanities (grade 3.98) like talking to strangers than students of technical sciences (3.72). The result was not surprising as students of humanities and social sciences have a certain ease of oral expression and do well in oral tasks at academic level. In our experience, both groups of students are quite apt in using a range of speaking skills in oral presentations with academic and professional topics. However, it seems that students of humanities enjoy small talk with people in everyday, ordinary situations and that they speak quite naturally and spontaneously outside of the classroom in informal contacts. In the free writing section of the questionnaire some respondents confirmed this communication in extra-curricular situations: "I use English every day and it will help me to communicate with people all over the world" and "I travel a lot and I communicate mostly in English." Another one expressed the desire to learn English with native speakers. Some scientists argue that the gender difference may account for more or less talking because of "different brains" but others disagree and say that males and females talk equally but differ in topics. Although there are more male students at the Faculty of Mining, Geology and Petroleum Engineering and more female students at the Faculty of Humanities and Social Sciences, this research did not focus on gender difference within individual statements, so we cannot make conclusions on that basis. 


\section{LIKE TALKING TO STRANGERS IN ENGLISH}

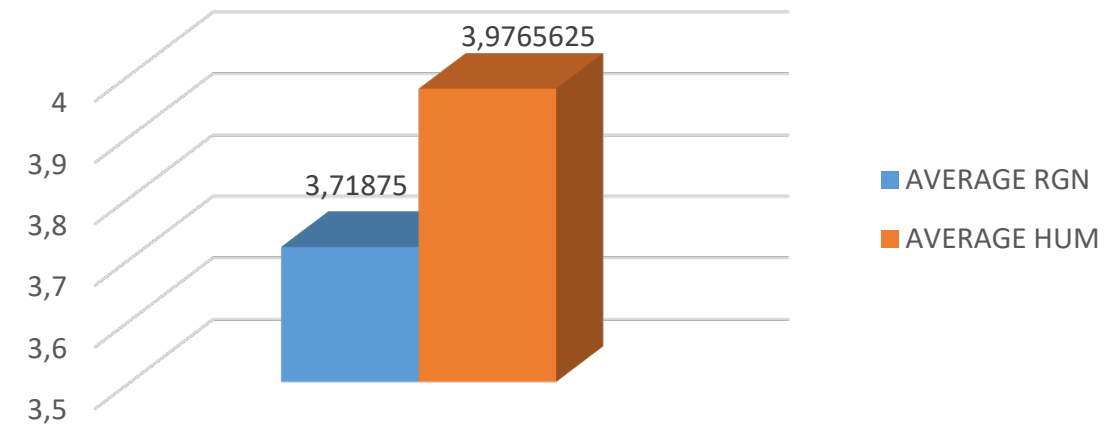

Figure 4: I like talking to strangers in English

\subsubsection{I would take English even if it were not an obligatory subject}

The students of humanities turned out to be more motivated for learning English regardless of the fact whether or not it was an obligatory course. The fact is that the course of English is obligatory for both groups of students. The difference lies in the type of course since students of humanities and social sciences enrol into English for specific purposes (ESP) and the other group studies English for academic purposes (EAP). Both courses develop same language skills and students should acquire similar competences. The difference is the fact that ESP aims at professional language learning and students focus on their specific fields while EAP is, in a sense, more general and all students work on a range of subjects from the field of humanities and social sciences. Therefore, the first group of students acquires a lot of technical vocabulary necessary for their work while the second covers different subjects, not strictly the material referring to their narrow field of study. However, we do not know whether the course content had any influence on their answer. What we know is that, in this case, the integrative motivation for learning English resulted higher in students of humanities and social sciences. 


\section{WOULD TAKE ENGLISH EVEN IF IT WERE NOT AN OBLIGATORY SUBJECT}

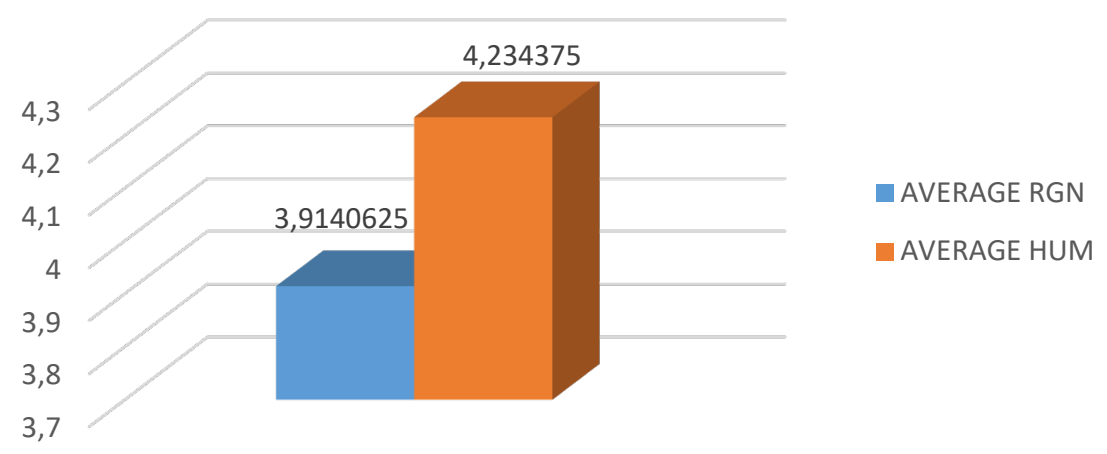

Figure 5: I would take English even if it were not an obligatory subject

\subsubsection{I frequently communicate in English on social networks}

According to the results, the students of humanities communicate in English on social networks more frequently than the engineering students. However, the margin is pretty narrow, 3.49 versus 3.34 . One might think that students of technical sciences would be better with and more oriented towards electronic communication than the others. However, today's young generation is known as "digital natives", as children born and grown with technology. Considering this, the fact that all students, no matter whether they study technological or social sciences, communicate through social networks to a similar extent does not greatly surprise. What we do not know is the amount of communication on social networks in Croatian. That brings up the question whether students of humanities really communicate more on social networks in general or just in English. Nevertheless, it turns out that, on average, both groups of students prefer live communication to communication on the net, in spite of higher percentage in favour of the students of humanities in both cases. 


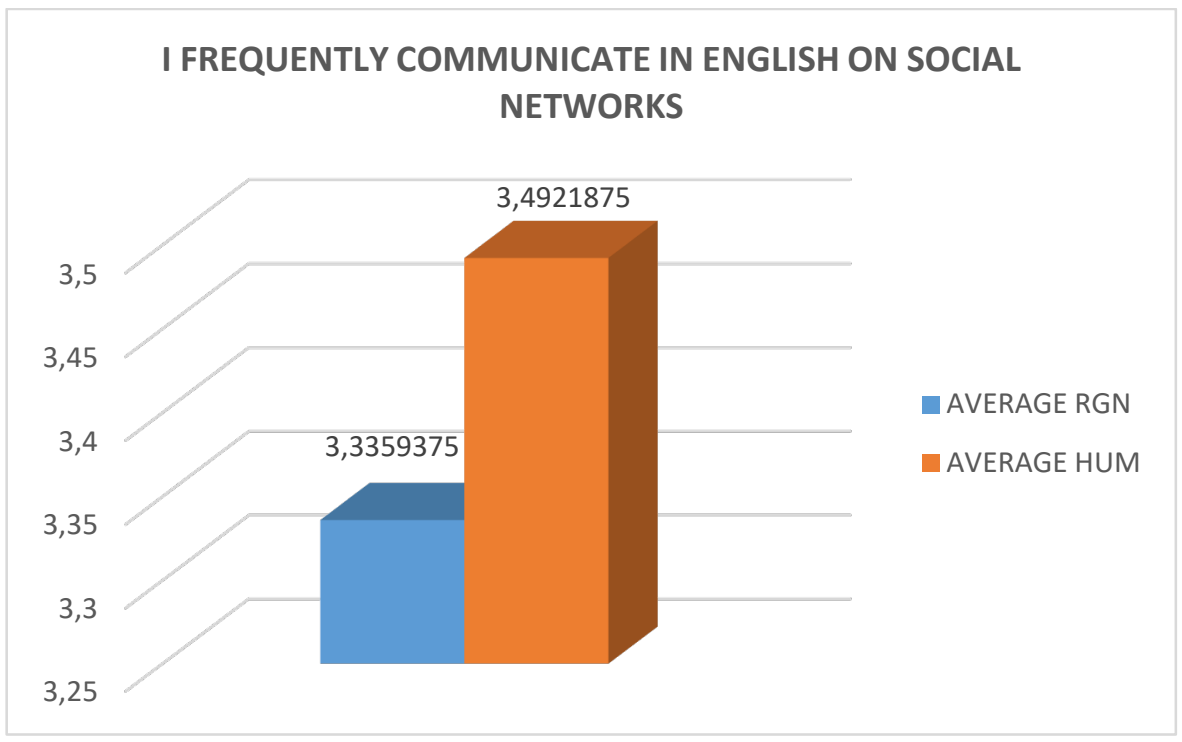

Figure 6: I frequently communicate in English on social networks

\subsection{Instrumental Motivation}

\subsubsection{The knowledge of English is important for professional development}

According to the chart, the percentage of students who consider English important for their professional development is higher at the Faculty of Humanities and Social Sciences. As it was previously said about the importance of English for personal development, it seems that the students of humanities see English more important for their professional than personal development, while the engineering students give priority to personal development. A possible interpretation of this result could be the fact that students of humanities who were surveyed in this research belong to so-called non-philological groups, their majors being other than languages. Therefore, they may connect the importance of English to reading and understanding professional literature, most of it being in English. They may, however, learn languages other than English, prefer them and find them more important for their personal and overall development. Whatever the reason, the students of humanities turn out to be instrumentally motivated for learning English while the engineering students seem to have integrative motivation. Some of the opinions of these students confirm 
instrumental motivation, e.g. "English is definitely not the language that sounds nice to me and that I would like to speak regardless of its global importance. However, considering its dominance and omnipresence in the world I'm glad I speak it and learn it since it offers different possibilities on professional as well as on personal level."

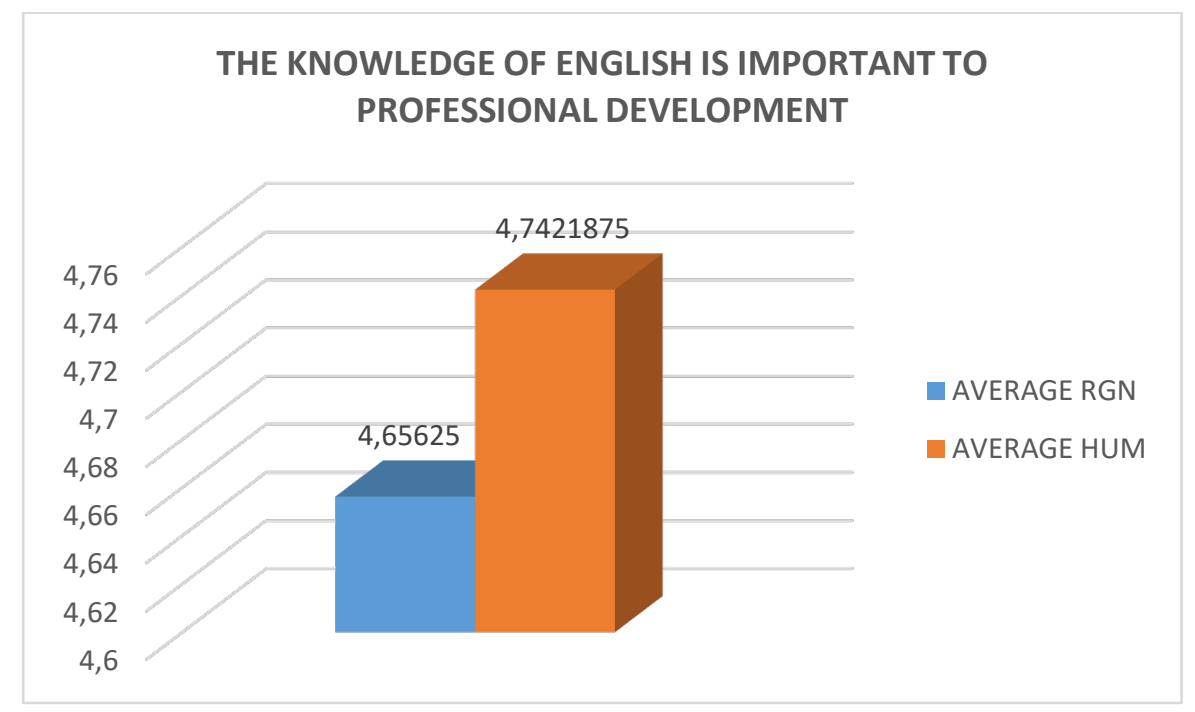

Figure 7: The knowledge of English is important to professional development

\subsubsection{I am learning English because of my family/environment}

The external factor as a motivation for learning English such as family and environment emerged as more important for the engineering students (2.37) than for the other group of students (2.1). We suppose that at younger age children learn English because their parents decide and want so. Parents are more aware of the global importance of English than the children really understand it or have the desire to learn it. So, parents decide, take their children to classes and pay for the instruction. Still, later in teenage and academic period parental influence decreases as students realize the value of proficiency and fluency in English. This is probably the reason why both groups of students graded this statement with very low marks. So, we may conclude that, at this point, their integrative motivation is stronger than instrumental, that is to say, that they learn the language for themselves and not because somebody told them or forced them to do so. 


\section{AM LEARNING ENGLISH BECAUSE OF MY FAMILY /ENVIRONMENT}

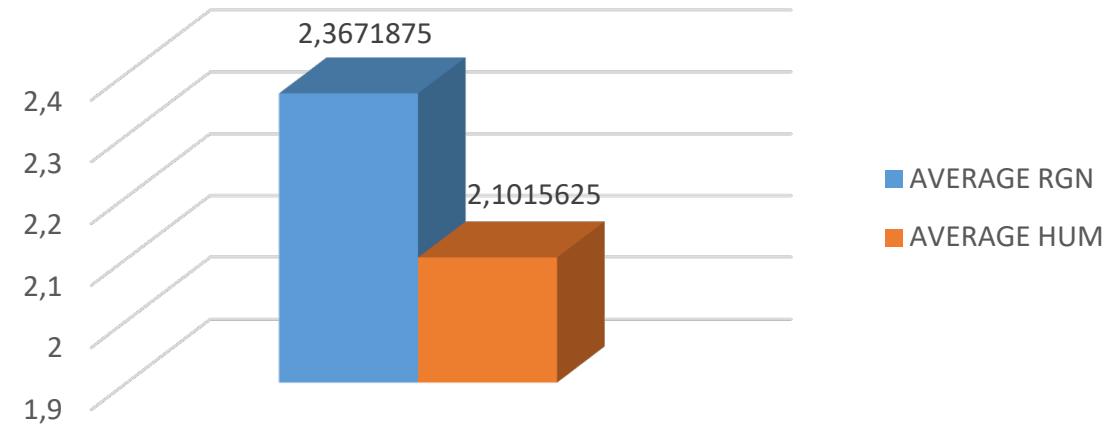

Figure 8: I am learning English because of my family / environment

\subsubsection{English is the most frequently learned language in the world}

This commonly held belief got high grades in both groups of students but resulted to be more present in students of technical sciences, who ranked this statement as high 4.62, than in the humanities group with 4.23. For the former group it is also the only language offered and studied at tertiary level. Meanwhile, in addition to English, the students at the Faculty of Humanities and Social Sciences are offered a number of European languages to enrol in as elective courses. Thus, they can decide to take German, French, Spanish, Italian and Russian courses. Due to the Bologna university system these students may choose to study these languages and find them important and useful because of student exchange programmes based on the mobility principle. Furthermore, the students of humanities are in the environment where other, extra-European languages are studied that geographically cover wide areas, include most numerous world populations and belong to the countries of origin with rising economies. Such languages are Chinese, Hindi and Arabic. Nevertheless, the previous research conducted at the faculty of Humanities and Social Sciences (Jelovčić, 2010) confirmed that the majority of students actively used only the English language (52.5\%), roughly one third of the students used English and another language (31.2\%) and a minority spoke more than two foreign languages $(12.8 \%)$. Therefore, we believe that, in terms of second language learning, English is still the first choice and it holds the leading position in Europe and in 
the world. This is also how our students perceive English judging from the high grades they gave to this statement.

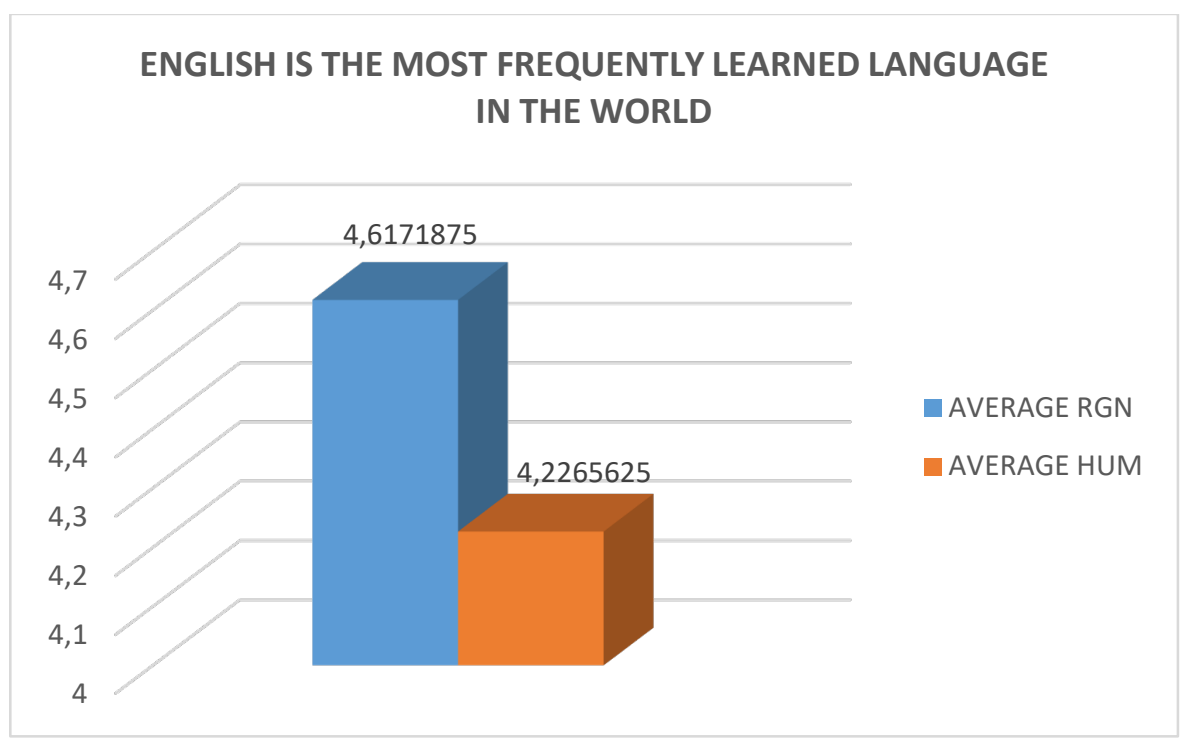

Figure 9: English is the most frequently learned language in the world

\subsubsection{English is important in today's world}

Students of both faculties ranked this statement with highest grades recognizing thus the worldwide importance of the English language. Students of humanities valued English with the highest grade among all the statements, 4.95, and the engineering students followed closely with 4.87. In the last, descriptive part of the questionnaire numerous comments confirm their attitude towards English being important nowadays. Thus, one of the respondents said: "English is the most important language of global communication and it is essential to learn it from the earliest age." Another one added: "I consider English very important and today it is implied that everybody should speak English. My opinion is that it should be the first language in all elementary and secondary schools." Another student stressed the importance of English at the tertiary level of education: "I consider English very important for academic success." Other comments emphasize the presence of English in all the fields of everyday life such as business, industry, popular entertainment, travelling, technology, fashion trends and many more. Although we may speak about the importance of some other 
world languages with rapidly increasing populations and their worldwide distribution, it is widely accepted that, at the moment, English is the "lingua franca" of the world, making it thus the most dominant and wide-spread international language. Or, in the words of one of our students: "English connects the world".

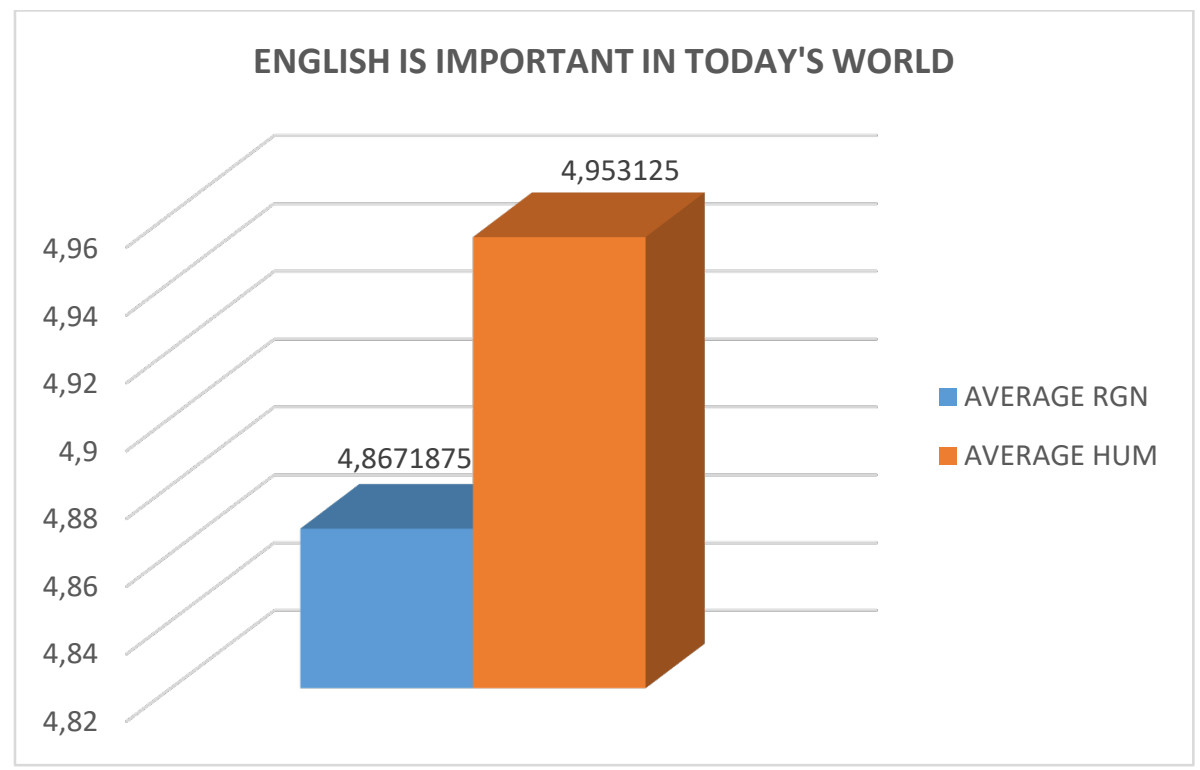

Figure 10: English is important in today's world

\subsubsection{English is the language of technologies}

This statement got high grades with almost no difference from both groups of students. We expected somewhat higher results in students of technical sciences because technology is their profession. However, we are aware of the overall importance of technology for the popularly called millennials, generation characterized by frequent use of the media, information technology and the most modern digital technologies including smartphones and tablets. They dedicate a great amount of their time to social networks, included in this research, and to using numerous applications. Using technology today mostly implies using English so we believe that many of our students, who are internet and technology users, use English spontaneously, without being aware of it. Therefore, we can 
definitely agree with our students when they consider English the language of technologies.

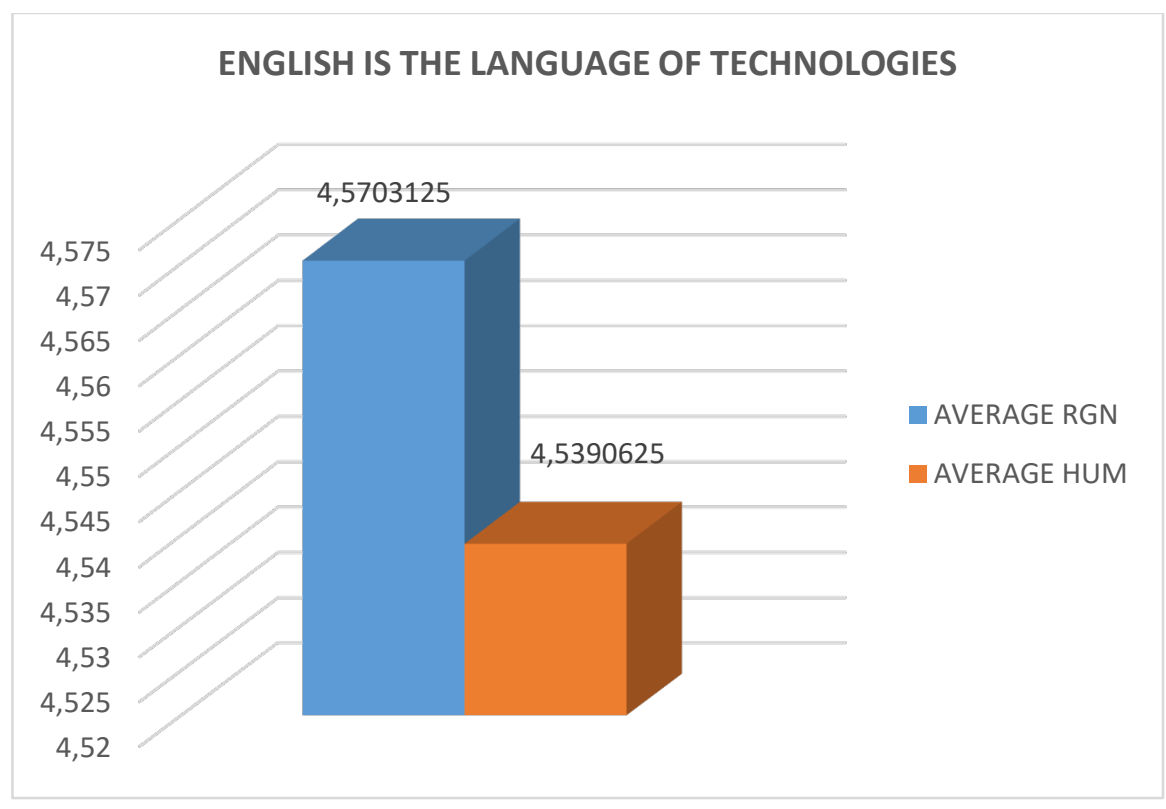

Figure 11: English is the language of technologies

\section{$4 \quad$ Discussion}

The results of the research show that there are more similarities in attitudes between the two tested groups of students than differences. The margins may be narrower or wider regarding various issues but the differences in ranking never seem too big or significant. Some statements are graded higher and given greater importance than some others which are considered less important. Both groups of students find English important for their personal and professional development. The difference is that engineering students give precedence to personal aspect and the students of humanities stressed the relevance of this language for their professional development. Thus, the first group resulted to be more integratively and the second more instrumentally motivated in this case, which was surprising since the opposite outcome was expected. Both groups gave the lowest grade to family and environment as an external reason for learning English so neither of them turns out to be instrumentally motivated in this way. Both groups think that English is the language of technologies. The 
highest grade is given to the overall importance of English in today's world. The widest margin between the two groups results to be in communicating in English on social networks, so students of humanities communicate in the foreign language via computer networks significantly more than the students of technical sciences.

The results, however, show that, despite our expectations, on average, higher grades are given to external reasons for learning English, such as professional development, English as the most frequently learned language in the world, as important language and as language of technologies. On the other hand, factors of internal motivation such as reading books and magazines and talking to people were given lower grades. Thus, it turns out that our hypotheses were only partly confirmed, and that, in spite of having rather high integrative motivation the students still resulted to be more motivated instrumentally. So, it appears that in spite of the possibly great desire and drive to achieve goals, it is more their obligations, examinations and career prospects that motivate students to be efficient and successful in professional language learning.

\section{Conclusion}

The results of the research presented in this paper lead to several conclusions. Students are aware of the global importance of English and its relevance for their personal and professional development. They are surrounded by English in their everyday life and emphasize its omnipresence in the media, publications and pop culture. They read books and magazines in English and speak to native and other speakers of English whenever it is possible. Students consider English to be not only useful but also indispensable for their academic success and future career. It is the most frequently learned language in the world and its knowledge offers new opportunities and enriches experience. As the language of technologies English enables professionals for new and more efficient ways of communication through modern technological devices. Finally, students stress the fact that they like English. This affective factor makes their motivation stronger and shows their inner willingness, desire and enthusiasm for learning English. And this is definitely something that we, teachers of English at academic level, should benefit from and direct them towards successful professional language learning. 


\section{References}

Clément, R., Dörnyei, Z. \& Noels, K. A. (1994). Motivation, self-confidence, and group cohesion in the foreign language classroom. Language Learning, 44, 417-448.

Gardner, R. (1985). Social psychology and second language learning. The role of attitudes and motivation. London: Edward Arnold.

Encyclopedia Britannica online. Retrieved September 10, 2018, from https://www.britannica.com/topic/Likert-Scale

Jelovčić, I. (2010). Strani jezik struke - analiza stavova studenata. Metodika, 20(11). 44-55. Mihaljević Djigunović, J. (1997). Research on the affective domain of EFL Learning: A study of motivation. Studia Romanica et Anglica Zagrabiensia, 42, 257-268. 


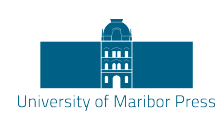

\title{
I Cast My Words upon Thee
}

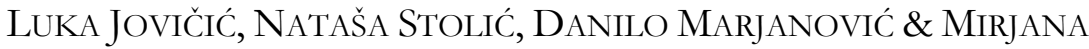 \\ SAVIĆ OBRADOVIĆ
}

\begin{abstract}
The eternal necessity to establish effective communication has been our weft. We have weaved our language threads into a tapestry via music, ecology, computer science, and language. Aware of the fact that modern advancements bring into focus a new way of interacting, our intention has been to connect the pieces which keep the traditional values tackling the latest trends. We have generated some practical ideas that can be implemented in the class. As a students-teacher quartet, we believe we can provide unique perspective from both angles of the classroom. After all, we share the goal of communicating our intents effectively. We discuss ways to convey information in/to different subject areas using interactive exercises, offer ideas for improving it and suggest a new approach to learning and teaching. So, I cast my words upon thee, and thou... do not toss behind thee any of these words, neither mine nor thine!
\end{abstract}

Keywords: $\bullet$ interaction $\bullet$ games $\bullet$ ecology $\bullet$ technology $\bullet$ music $\bullet$

CORRESPONDENCE ADDRESS: Luka Jovičić, Undergraduate Student, University of Belgrade, Faculty of Mathematics, 16 Studentski trg, 11000 Belgrade, Serbia, e-mail: luka.jovicic16@gmail.com. Nataša Stolić, High School Student, Mathematical Grammar School, 37 Kraljice Natalije Street, 11000 Belgrade, Serbia, e-mail: natasa.stolic01@gmail.com. Danilo Marjanović, High School Student, Mathematical Grammar School, 37 Kraljice Natalije Street, 11000 Belgrade, Serbia, e-mail: natasa.stolic01@gmail.com. Mirjana Savić Obradović, BA, English Teacher, Mathematical Grammar School, 37 Kraljice Natalije Street, 11000 Belgrade, Serbia, email: savic.obradovic@gmail.com. 
"If you talk to a man in a language he understands, that goes to his head. If you talk. to him in his language, that goes to his heart."

(Mandela)

\section{The Terminology Project}

It is our own ESP experience that starts with the words like '(a) pro forma invoice', 'swift', 'edutainment', 'cookies', etc.

Having in mind the necessity of communicating across the world both via general English and ESP/ EAP, we decided to conduct a survey - the Terminology Project.

Within our Terminology Project, we submitted a request in pursuit of a 'corresponding' link among Ecology (E), Music(M), the English Language (EL), Computer Science (CS) and Applied Science (AS) vocabulary. The comprehensive list-to-be initially comprised a selection of Ecology terminology, and the task was to try to provide a Music term for an Ecology term, or a Computer Science word or a phrase for the same Ecology term, etc.

In the same attitude survey, we put a question: "What connection do you see in learning professional foreign languages (English for Specific Purposes) and the concept of communication between cultures?", and this issue brought us to the following findings.

The responses we received could be divided into three categories:

$$
\begin{aligned}
& \text { A - received: a) positive \& b) negative, } \\
& \mathrm{B} \text { - discussed, } \\
& \mathrm{C} \text { - not received. }
\end{aligned}
$$

The chronological order of the received answers was the following:
1. Petra (Slovenia)
2. Maria Teresa (Argentina)
3. Mauricio (Argentina) 
4. Brigitte (Belgium)

5. Renato (Romania)

6. Jose Guillermo (Mexico)

7. Gilberto (U.S.A.)

8. Jill (U.S.A.)

9. Eva (Norway)

10. Jutta (Norway)

11. Filip (UK)

12. Nataša (Serbia)

13. Vera (Serbia)

As for the points of discussion, our survey participants (Serbia, Argentina, U.S.A.) asked for further clarification pointing out it was hard for them to follow what was required from them. However, they wanted to be introduced to every precise detail in the attempt to comprehend what the aim of the project was.

Finally, no ideas were generated from Japan, Malaysia and Bulgaria. Still, we believe that the communication level can be achieved with/within these cultures via the same technique, because, as Ludwig Wittgenstein put it: "Die Grenzen der Sprache sind die Grenzen der Welt" (English: "The limits of my language mean the limits of my world.”)

The answers that kept our attention were:

1. "It is important to be able to speak a foreign (professional) language, but even more important it is to be careful and tolerant when interacting with people from other cultures." (Mauricio, Argentina)

2. "Learning a language for professional purposes does not enhance the communication between different cultures despite that a new language opens up the possibility to interact in different environments." (Jose Guillermo, Mexico)

3. "Better communication requires listening to one another, while today most of us only pay attention to what they have to say and do not actually listen." (Brigitte, Belgium)

4. "I think that studying English as a professional language is of paramount importance for the communication between cultures because through English one has access to a vast amount of highly specialised literature." (Renato, Romania) 
5. "Learning a different language for purely professional reasons, such as translation of technical papers, does not enable much cultural communication since the emphasis is upon the written, not spoken language." (Jill, U.S. A.)

6. "An English language course for Mathematics students will need, at some point, to intersect with the culture - some authors call it 'subculture' - of the mathematical community. " (Gilberto, U.S.A.)

7. "In a time of globalisation and work outside of one's own country, it is important for people to share a language. If not, they would not be able to conduct their work nor would they be safe in their workplace. " (Eva, Norway)

Also, we want to single out the next Terminology soluions:

- Petra, Slovenia: E - Hybird, M - Instrument, EL - Energy, CS - Mobile unit, AS - Bipolarity

- Nataša, Serbia: E - Oxygen, M - Notes, EL - Words, CS - Pixels, AS Atoms

- Filip, UK (age 14): M - Dissonance -Broken keyboard; M-Performance, CS-Output

- Vera, Serbia: E- Eco term, M- Treble clef, EL- Lettter, AS- Barcode

With the Terminolgy project, our full commitment to an innovative approach in ESP studying was reaffirmed because "there is no better means to light students' fire than to involve them in authentic and challenging communication..." (Warschauer, Shetzer, \& Meloni, 2002, p. 47) By aiming at the needed information, we felt we did the communicative networking and culture merging. 


\section{Activities}

\subsection{The Crossword}

Level: All levels

Time: 10-20 minutes

Aim: Practice of vocabulary and team work

\section{Description of the task}

The rules are simple. First, participants should split up into pairs or groups and have a look at the handouts. The aim of the activity is to fill in the squares with the letters, forming either words or phrases, by solving clues, which lead to the answers. The word that appears in the darker squares is the key word. Then discuss the meaning of the word with your pair/group member/s. All of the answers are English words which are common in a specific scientific field.

\section{Items}

1. a musical performance given in public, typically by several performers or of several compositions,

2. an increase in the earth's average atmospheric temperature that causes corresponding changes in climate and that may result from the greenhouse effect,

3. an elaborate musical composition for full orchestra, typically in four movements,

4. the faculty by which the mind or computer stores and remembers information,

5. a small object that you press to operate a device or a machine,

6. a device used to produce music,

7. the science or practice of the diagnosis, treatment, and prevention of disease,

8. a flat panel or area on an electronic device such as a television, computer, or smartphone, on which images and data are displayed,

9. a building or room containing collections of books, periodicals, and sometimes films and recorded music for use or borrowing by the public or the members of an institution,

10. a strong, regular repeated pattern of movement or sound, 
11. facts provided or learned about something or someone,

12. a prolonged period of abnormally low rainfall, leading to a shortage of water,

13. the method of human communication, either spoken or written, consisting of the use of words in a structured and conventional way.

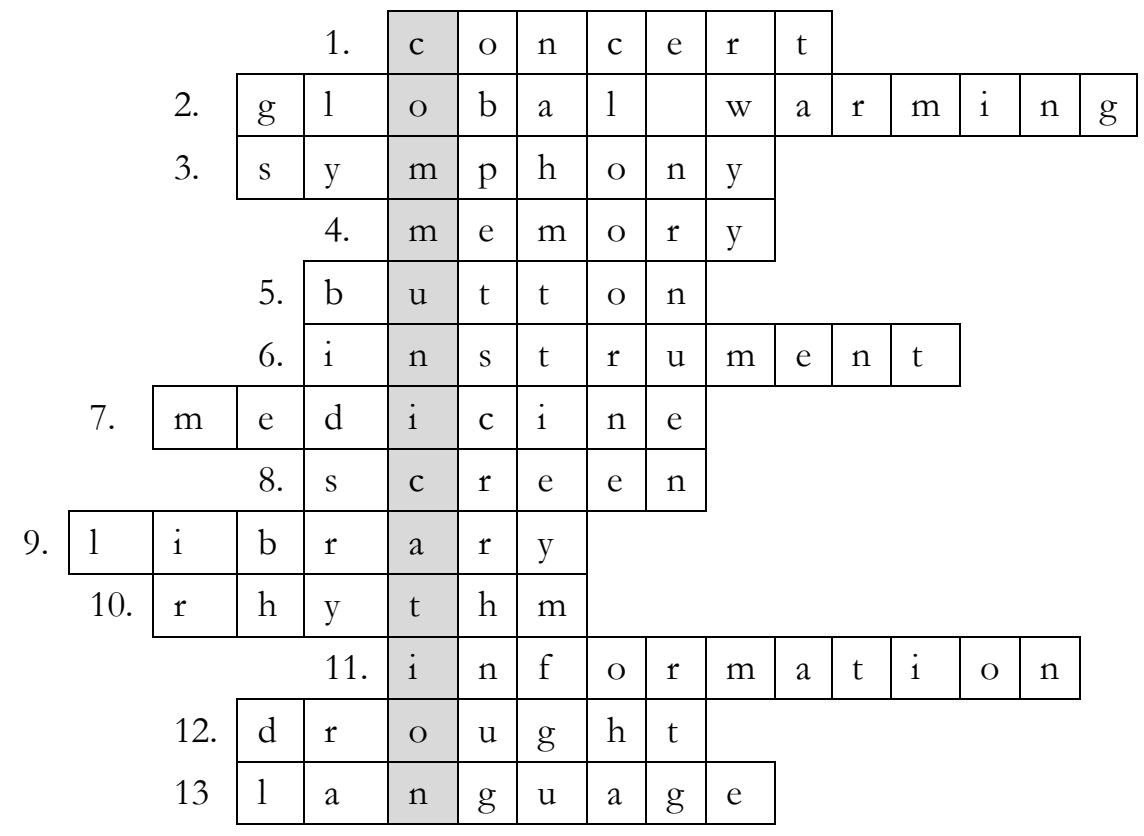

Table 1: Crossword solution

\section{$2.2 \quad$ Icon Jewellery}

\section{Rationale}

The fact we are in Celje, famous for its Zlatarna Company, has inspired me to share my 'Jewellery Story' with you. I remember, when I was a little boy, my grandmother used to make necklaces of various materials she could find in the house. Have you ever done it? 


\section{Assignment}

Students are provided with different icon symbols (Ecology, Music, the English Language, Computer Science, Applied Science). They are instructed to make a necklace of their own by choosing, at least, three icons and explain what ESP value the jewellery has.

\section{Preparation}

A few of necklace length pieces of thread are needed. It is important to have small pieces of cardboard in the square shape with different symbols belonging to different fields of interest, in this case, Ecology, Music, the English Language, Computer Science, and Applied Science.

\section{Discussion}

This pair work or group work activity is aimed at exchanging ideas and speculating about the ESP terminology that is 'hidden' by the given symbols.

\section{Feedback}

The activity participants usually feel engaged and relaxed about deciding on their icon selection. The cardboard pieces, preferably in different colours, do find their place around students' necks. The discussion gets kindled; in that way, it encourages their speaking skills.

\section{Conclusion}

It is important to emphasise how vital communication for humans is. So vital, that some researchers, such as Watzlawik, Bavelas, \& Jackson (1967) pose it as an axiom: "One cannot not communicate". There's no antipode to behaviour, and everything one does is a form of communication, verbal or otherwise. As a part of the Terminology Project, we asked respondents about communication between cultures. We were interested in whether they see any link between that and LSP and why. Most of the responses stated that English is an essential skill, a lingua franca of the world. Many of them also included 'globalisation' in some way. They seem to embrace the transformative view of globalisation and acknowledge it is making real, lasting changes. The world has been more 
connected than ever, and English seems to be the common link. As expected in a language for specific purposes context, almost all of the responses mentioned the workplace and job market-English is unavoidable in that context. Globalisation makes global companies, and global companies predominantly communicate in English.

Teaching children in schools is the preferred route: the age of students in the second half of elementary school and high school is usually considered optimal for language acquisition (Krashen, Long, \& Scarcella, 1979; Nikolov \& Djigunović, 2006). We talked about our experiences, and as we are all tied to the high school environment, we devised our methods accordingly. But it is our wider goal to make it applicable to other contexts as well. Being such an essential skill, learning of English is not, and should not be, confined only to school classroom. Language is everywhere, and one should use its omnipresence to diversify means of adopting it.

The demonstrated exercises are a nice example of learning by association. By trying to connect known basics with new knowledge in LSP, an attempt is made to strengthen the connection between the two and easen the adoption of new words. After all, it is the very same way some words took when acquiring the new meanings. For example, 'cookie' on the table seems to have very little in common with what we call a 'cookie' on a computer-one is edible, the other is a small virtual file hidden away somewhere. One you could reference in the culinary class, the other in IT, but neither really fits both. However, by visualising a literal cookie, or even better by reminding students of a story of Hansel and Gretel and their cookie crumbs, we can trace back the way that word went through. That very story is the common link between them: computer cookies are nothing else but "breadcrumbs" left by websites on computers. By following metaphorical crumbs, we arrive at a sensible explanation with a memorable connection. Every word makes sense and has plenty of different and related usage, it is just a matter of finding that sense and connecting it to a more common term.

The term that often goes hand in hand with this type of learning is 'edutainment'. A portmanteau of 'education' and 'entertainment', it has been discussed under different names as far back as during the eras of Renaissance and Enlightenment (Němec \& Trna, 2007). Later, Walt Disney is acknowledged to have re-ignited the movement with his educational cartoons (Disney, 1954). In the twenty-first 
century, yet again it has garnered another face, thanks to the technological advancements. From our point of view, it seems that the very devices which spurred the globalisation process, computers, are underutilised in the classroom. Bringing interactivity to the students using tools they already know and are proficient in can be extremely fruitful. An interesting story, a vivid image, a memorable video or a catchy song can go to great length. They all share a common characteristic; it is all about making connections and associations. All of them are very much doable using only a computer, or even better, a mobile device which is lately more and more a part of life of younger students. Depending on the audience, the teacher should find something which is memorable to the students, and connect it to the subject being taught.

We mentioned music and the environment. Let us give one example of a story. When Greg was fifteen, he and his friends decided to form a punk band. It kicked off well, they got popular. Greg went on to earn a $\mathrm{PhD}$ in history of science and teach some courses in a few US universities. Fifteen years ago, the band released a song dedicated to the Kyoto protocol: Kyoto Now (Graffin, 2002). Kyoto protocol is an important part of limiting the carbon dioxide emissions. The band still has a successful career; they are called Bad Religion and are considered pioneers of punk rock. As punk-rockers, there are many interesting stories related to them (as with any other influential artist). We can use them to introduce new concepts or terms. Bad Religion alone have a dozen more environment-oriented songs. For any relevant topic, there are probably several songs of various genres covering it.

The only hurdle yet to be overcome for full-fledged interactivity is software support. For most things, it is only 'up and coming'. Ideally, there should be platforms for interactive learning in the classroom which synchronise, for example, to mobile devices outside school. Unfortunately, nothing is wide use as of this moment, but we are confident that it is bound to change in the future. In our school, we use what is available to us now. The rest can still be done in a more analogue, yet non-traditional way, in the same spirit as more digital counterparts. Most of all, we believe this is not an approach only viable for younger population or particular place. With some effort, it can be adapted to suit any specific audience. Games, songs and stories are essential to humans, regardless of age and culture. Let us use them for teaching too! 


\section{Acknowledgments}

We owe special thanks to the following people: Prof. Polona Vičič, $\mathrm{PhD} \&$ the Organising Board for inviting us to participate in the Conference, and for giving us a great deal of guidance and encouragement in terms of technical issues. We also give our thanks to Mathematical Grammar School - Mr. Srdjan Ognjanović \& Almagi Foundation for supporting us actively and financially which made our team work and Conference participation worthwhile.

\section{References}

Graffin, G. (2002). Kyoto Now! [Recorded by Bad Religion]. On Process of Belief [CD]. Hollywood, United States: Epitaph.

Disney, W. (1954). Educational values in factual nature pictures. Educational Horizons, 33(2), 82-84.

Krashen, S. D., Long, M. A., \& Scarcella, R. C. (1979). Age, rate and eventual attainment in second language acquisition. TESOL Quarterly, 573-582.

Mandela, N. [Quotation]. Referenced in Laka Mugarza, I. (2014). Mandela was Right: The Foreign Language Effect. Mapping Ignorance.

Němec, J., \& Trna, J. (2007). Edutainment or entertainment. Education possibilities of didactic games in science education. In J. Němec (Ed.), The Evolution Of Children Play-24. ICCP Word Play Conference (pp. 55-64). Brno: Pedagogická fakulta, Masarykova univerzita, Brno.

Nikolov, M., \& Djigunović, J. M. (2006). Recent research on age, second language acquisition, and early foreign language learning. Annual Review of Applied Linguistics, 26, 234-260.

Warschauer, M., Shetzer, H., \& Meloni, C. F. (2002). Internet for English teaching. Alexandria: Tesol.

Watzlawick, P., Beavin, J. T., \& Jackson, D. (1967). Pragmatics of human communication: A study of Interactional patterns, pathologies and paradoxes. New York, NY: Norton \& Company. 


\title{
Analysis of Student Needs - A Prerequisite in Designing ESP Course Curricula
}

\author{
KSENIJA JuRETIĆ, KRISTINA KAŠTELAN \& DANIELA KRUŽIĆ
}

\begin{abstract}
English, the lingua franca especially in business, is of essence in the education of future economics and business graduates. In order to design a suitable ESP course curriculum offered at higher education institutions, or modify an existing course(s), one has to determine the language needs, or should we say gaps, of the target audience. Namely, in our experience as language teachers, the student population enrolled in such courses is rather diversified, both in terms of general language competence and in terms of their knowledge and understanding of business concepts. The authors analyse student needs based on diagnostic (initial) testing covering business terminology and language contents. The sample used in the analysis includes 86 students enrolled in the first year of undergraduate studies taking LSP courses in Business English. Moreover, by applying multivariate statistical techniques, the authors want to investigate the effect of individual respondent characteristics on the initial test results, such as field of previous education (grammar schools, secondary schools of economic orientation), the final grade achieved at the English Matura exam (secondary school exit exams), the knowledge of another foreign language, the number of years one has spent learning the respective language(s), gender and/or regional affiliation.
\end{abstract}

Keywords: - background knowledge - business terminology $\bullet$ course design $\bullet$ LSP $\bullet$ needs analysis $\bullet$

CORRESPONDENCE ADDRESS: Ksenija Juretić, PhD, Senior Lecturer, University of Rijeka, Faculty of Economics and Business, Ivana Filipovića 4, 51000 Rijeka, Croatia, e-mail: ksenija.juretic@ efri.hr. Kristina Kaštelan, mr.spec., Senior Lecturer, University of Rijeka, Faculty of Economics and Business, Ivana Filipovića 4, 51000 Rijeka, Croatia, e-mail: kristina.kastelan@, efri.hr. Daniela Kružić, univ.spec.transl., Lecturer, University of Rijeka, Faculty of Economics and Business, Ivana Filipovića 4, 51000 Rijeka, Croatia, e-mail: daniela.kruzic@,efri.hr. 


\section{$1 \quad$ Introduction}

Nowadays, with a lot of research being conducted and numerous articles being written on LSP, and especially ESP/EAP, we find it justifiable to start this introduction by quoting Upton's article (2012) 'LSP at 50: Looking back, looking forward" in which a reflective overview of the changing trends and focuses of LSP has been given:

Picking representative perspectives from different time periods is an individual choice, but most would not argue that leading thinkers in LSP -and specifically ESP - include Halliday, Strevens and McIntosh in the 1960s, Strevens in the 1970s, Dudley Evans and St. John in the 1990s, and Belcher in the 2000s (p. 14).

The shifts in focus are particularly obvious in three main areas that all ESP /EAP language scholars have focused on in their research but with different perspective:

(1) needs analysis,

(2) language analysis and

(3) materials and methodology.

However, this paper is not focused on the history of ESP, which has already been discussed by a great number of prominent language scholars, but on the underlying goal of LSP which has not been changed:

To help language learners gain access to the language they want and need in order to become successful members of the academic, professional or occupational community of which they seek to be a part. (Upton, 2012, p. 20)

Moreover, as the Faculty of Economics and Business Rijeka has conducted university study programs held in English for over seven years, we have a solid example of good practice in CLIL (Content and Language Integrated Learning) and a live proof that academic discourse nowadays is "more contextual than simply textual, dynamic than static, varied than monolithic, and interesting in its shaping of and being shaped by people" (Belcher, 2006, p. 142). Therefore, the 
paper starts with distinctive features of CLIL and ESP/EAP, followed by needs analysis and methodology of initial and final testing of students of economics, analysis of the test results and conclusions.

\section{Distinctive features of CLIL and ESP}

The acronym CLIL, coined by David Marsh in 1994, stands for Content and Language Integrated Learning that has become 'the umbrella term' describing content-based subject learning (biology, chemistry, geography, mathematics, accounting, finance, strategic management, marketing, etc.) through the medium of a foreign language. The distinctive features of CLIL and ESP are described by González \& Joseba (2013, p. 24) as follows:

CLIL and ESP share a number of key features, such as the use of content from different non-linguistic subjects, development of academic and communication skills, and use of communicative language teaching methodology. However, there are some key differences in these two approaches, and one of them is the objectives and learning outcomes. CLIL clearly states that content-learning objectives are equally or even more important than language-learning objectives, whereas ESP is language-led and language-learning objectives are of primary importance.

Owing to the fact that internationalization has become a must for most higher education institutions outside the English-speaking world, an increasing number of non-native teachers/academics of non-language disciplines (for instance, engineering, business, management, accounting, finance, medicine) use English as the language of instruction. Having already a seven-year university study program in English at the Faculty of Economics and Business Economics in Rijeka, our non-language academics have already gained a respectable experience in teaching their subject content in English. It has established a good collaboration and interaction with language teachers at the Faculty: exchanging knowledge, materials and experience in both content learning and language acquisition by mutually introducing wider cultural context that help students acquire learning outcomes. 


\section{Research background and methodology}

\subsection{The need for needs assessment}

As the business world shows a constant need for excellent language and communication skills, the higher education institutions require from their language teachers the constant improvement and development of the offered language courses. We as language teachers face another "challenge", which is the extremely diversified student population, enrolled in our courses. Thus, the research background of our study lies in evaluating language needs of the student population enrolled in ESP courses as to design new and/or modify the existing course curricula. Therefore, based on the initial test results and by applying multivariate statistical techniques, we want to quantify the effect of individual respondent characteristics on ESP acquisition such as whether the respondents have completed grammar schools, secondary schools of economic orientation or other, the final grade achieved at the Matura exam in English, the knowledge of another foreign language(s), and regional affiliation.

In order to modify the existing curricula, we try to establish the balance between the need for teaching content-based learning and developing students' general language competencies in formal and informal communication. We expect that the data gathered in this study may help LSP teachers to develop adequate and modern curricula based on three key learning outcomes that are targeted to be acquired during the course of study:

- to communicate successfully in a real-world business setting (understanding specific business context),

- to use a more generalized set of academic skills (conducting research, preparing and delivering presentations, preparing papers, reading and notetaking),

- to use the language of everyday informal talk (developing social skills as to communicate effectively with colleagues during the break at the conference, exchanging ideas and experience regardless of occupational context, choosing a good neutral topic as a conversation starter that everyone can discuss: arts, entertainment, sporting events, travel, work, hobbies... while chatting over coffee or writing/replying an informal email. 


\subsection{Methodology and sample}

Our research instrument consisted of two parts: an initial multiple choice test and a short questionnaire. During the introductory lecture the students were given an initial test which included 15 questions/statements testing general language skills i.e. grammar and 15 questions/statements dealing with business terms and concepts. Upon the initial test, the students were asked to complete a questionnaire consisting of 6 items. The questions in the questionnaire regarded the following issues: former education (items 2, 3, 4), Matura exam (item 6), language acquisition outside formal education (item 5), and gender (item 1).

Most of the items were targeted at formal foreign language acquisition i.e. the level and final grade achieved at the Matura exam in the first foreign language (secondary school exit exams), the number of years one has spent learning the respective language, the knowledge of other foreign languages whether learned within formal, non-formal or informal education (at school, on a course, at home, etc.). Items 1,2 and 3, addressed the following data: regional affiliation i.e. whether the schools the students have finished are located in cities with more than 50,000 inhabitants, between 15,000 and 50,000 and under 15,000 inhabitants, students' gender and the field in which students received secondary education.

In addition to the above mentioned data, we also collected data on student progress during the course including the results for class activity (0-70 grade points) and the results of the final examination in the same format as the initial test $(15+15$ grade points) and the final grade achieved (class activity + final examination grade points).

The sample initially included all students enrolled in the first year of undergraduate studies in economics, finance and accounting and international business at the Faculty of Economics and Business of the University of Rijeka, Croatia (hereinafter EFRI). The students, depending on former language learning, may enroll Business English, Business Italian or Business German. Business language courses 1 and 2 are obligatory courses within these study programs carried out in form of 20 lecture and 10 seminar hours. As only a few students took Business German courses and no students took Business Italian courses in the academic year $2017 / 2018$, we decided to leave them out of the 
sample. All of the students within the sample are full time students, studying in Croatian, who have enrolled the course in Business English 1 in the academic year 2017/2018. The sample thus included 113 students. However, we also decided to exclude additional 27 students from the sample due to lack of data. Namely, some of the students submitted partially completed questionnaires, or have not managed to acquire the minimum points required to sit for the final exam or did not sit for the final exam at all. In addition to these, we also decided to exclude those students who have not completed secondary education in the field of economics or a grammar school as their number is rather small (10) and their affiliation is not in the primary focus of our study. As a result our final sample consists of 86 students.

\section{$4 \quad$ Data analysis and results}

A descriptive analysis of the sample shows that out of the final 86 students, there are 64 female students and 22 male students, that 49 students finished grammar schools (gimnarija) and 37 secondary schools of economic orientation; that the place of their secondary education was located in a big city (35), medium sized city (23) and small city (28) and that 17 students have knowledge only of 1 foreign language (English), 43 of two foreign languages and 24 of three foreign languages and 2 more than 3 foreign languages. The average number of years of studying English as a foreign language was 12, the average final grade achieved on Matura was 3.53 and the average final grade achieved at the end of the Business English course at the Faculty 3.71. The results of data analysis based on frequency distribution regarding students' Matura grades and grades achieved at the end of the University course are given in Table 1 and Table 2. 


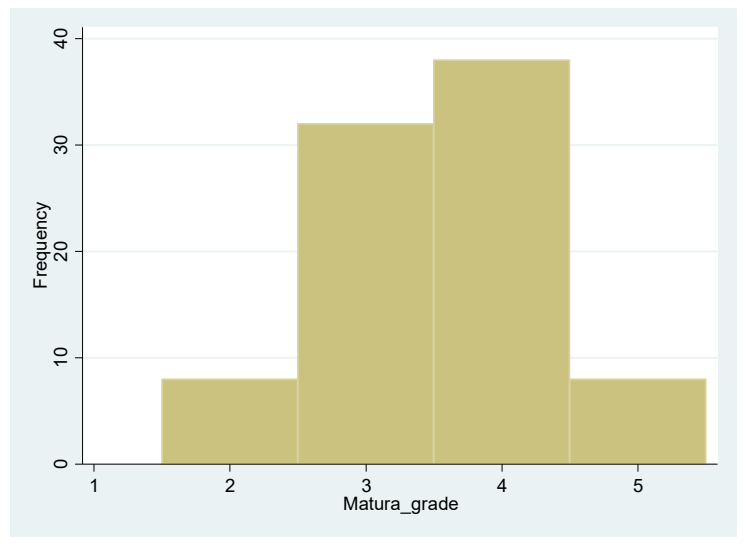

Table 1: Frequency distribution according to Matura grade

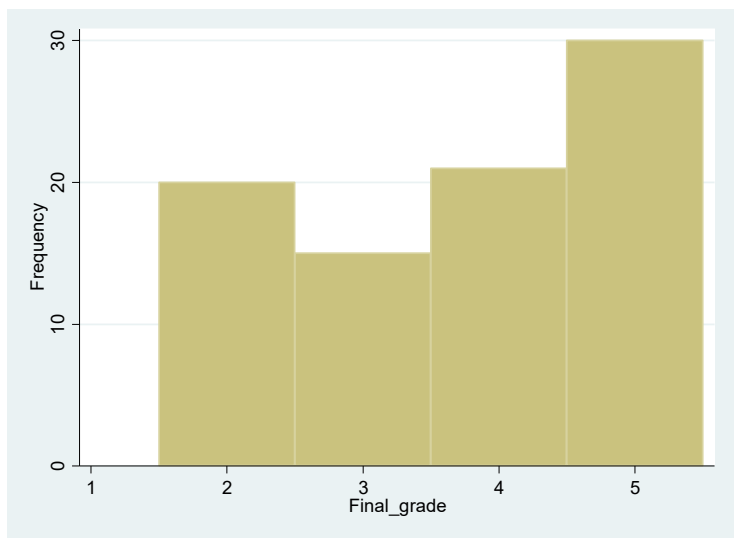

Table 2: Frequency distribution according to final grade

As can be noticed, the distribution according to final grade shows discrepancies with the Matura grade distribution. This may be explained by the inadequate grading system at the University of Rijeka, which has fortunately been changed starting from the academic year 2018/2019. Namely the grading system was as follows:

40-59.9 grade points $=2$

60-69.9 grade points $=3$

70-79.9 grade points $=4$

80 - 100 grade points $=5$ 
From 2018/2019 the grading system has been modified, thus, as can be seen from Table 3, giving a more representative and accurate picture of the actual progress. The grading system starting from the respective year is as follows:

$50-59.9$ grade points $=2$

$60-74.9$ grade points $=3$

$75-89.9$ grade points $=4$

90 - 100 grade points $=5$

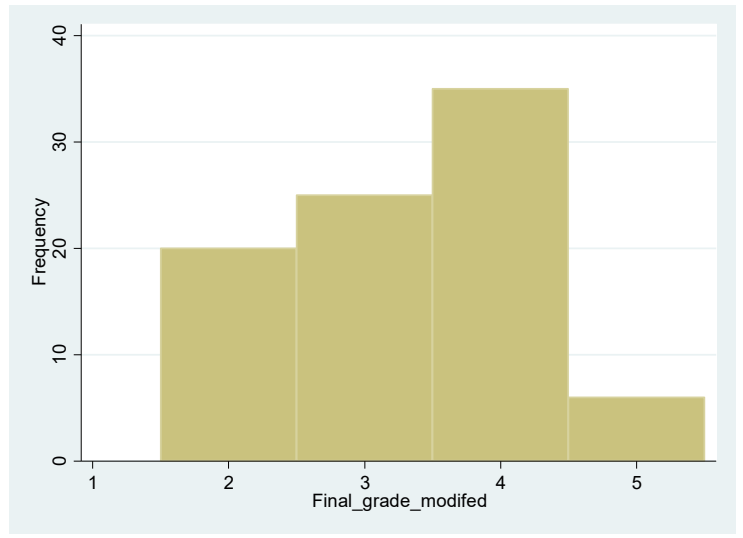

Table 3: Frequency distribution according to modified final grade

The only distribution discrepancy can now be seen among those students having grade 2. This is due to the fact that in our sample 18 students obtained passing grades (i.e. 2) with 40 to 49.9 grade points which would, if graded according to the new grading system, fail and would as such be excluded from the sample.

The T-test examining students' progress regarding vocabulary indicates that there is a significant difference in average results obtained on the initial vocabulary test and the final vocabulary test. As can be seen in Table 4, this difference is 4.5 points, which is a substantial increase $(74 \%)$. 


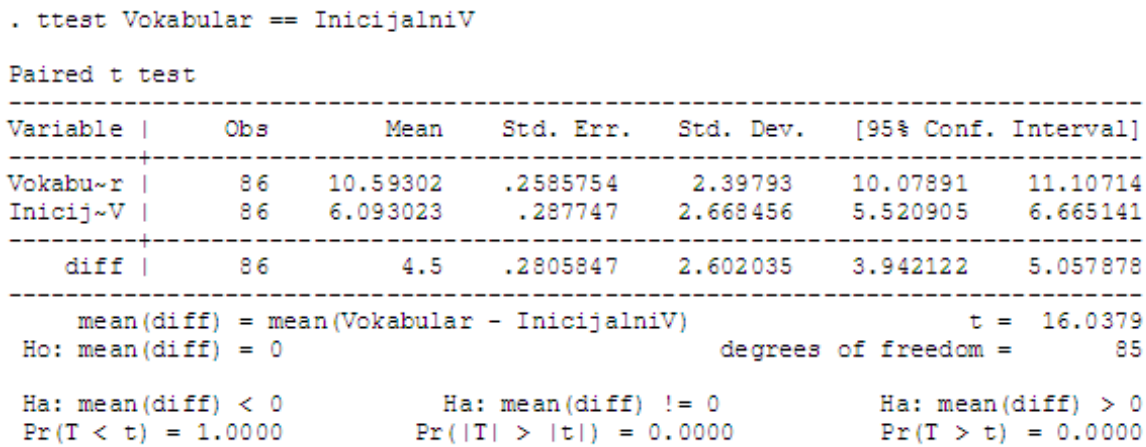

\section{Table 4: T-test regarding vocabulary progress}

The same can be observed for difference in grammar knowledge before and after the course, although the difference in this case is somewhat lower $(20 \%)$ but still significant (Table 5).

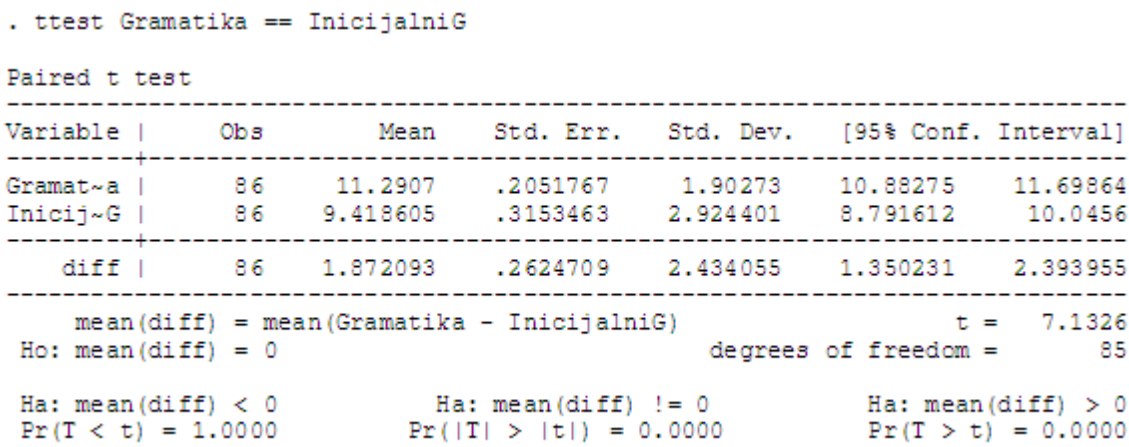

Table 5: T-test regarding grammar progress

To find whether former education i.e. whether the students come from grammar schools or those in economics, has an impact on vocabulary results i.e. vocabulary progress, we performed additional t-tests. The results show that there is no statistically significant difference between the two groups, 6.3 and 5.8 points respectively, when it comes to initial vocabulary results and 10.85 and 10.24, when it comes to final vocabulary results. Similar progress results can be observed when performing t-test regarding grammar. Namely, students coming from grammar schools obtained on average 9.85 initial grammar points and 11.63 
points (18\% increase) on their final grammar tests, while those having economics background had 8.83 and 10.83 points (23\% increase). It may be noted that the latter group showed a somewhat better progress in both categories.

The results of one-way ANOVA analysis, examining the differences in vocabulary and grammar results both on initial and final tests among the two groups of schools, showed a significant difference (at a 10\% significance level) only when it comes to final grammar results. However, it should be noted that even though there is no significant difference between schools regarding other variables, grammar school students showed slightly better results in all categories.

Furthermore, we also tested whether the location of former education has an effect on prior knowledge. The results showed no significant difference between the groups concerning vocabulary results, but showed that there is a significant difference in initial grammar results. Namely, students that have finished schools located in medium sized cities obtained better results than the other two groups as can be seen in Table 6 .

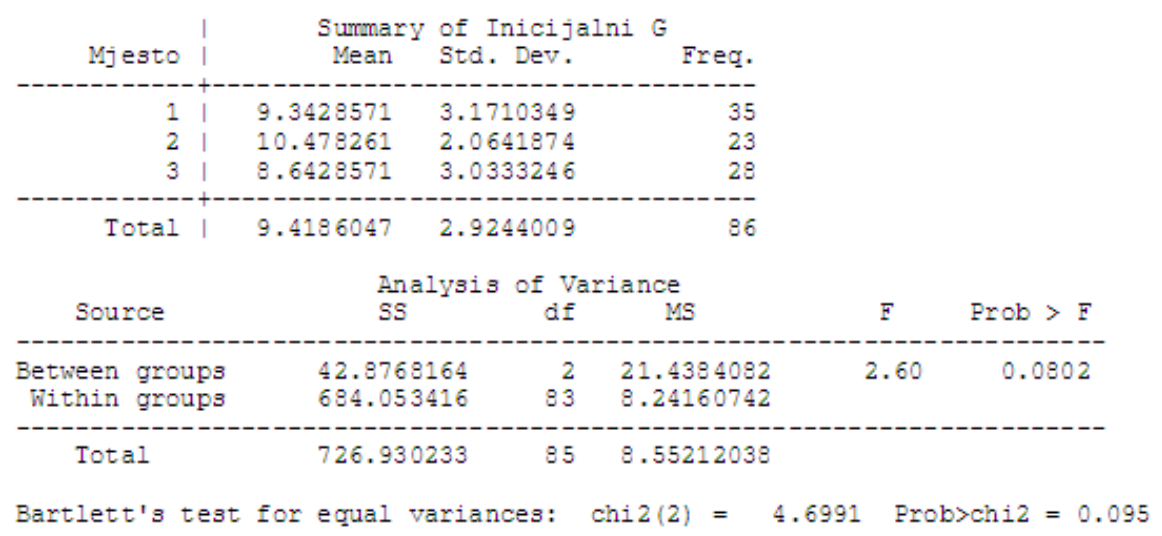

Table 6: ANOVA regarding prior knowledge of grammar 
However, when we examined whether location has an effect on student progress we found no significant difference between the groups. Furthermore, while students from medium cities achieved on average the best results in all four tests, the students from smaller showed most progress.

Finally, we performed regression analysis to investigate the effect of individual specific variables on initial vocabulary and initial grammar results and found that gender (questionable due to the female to male ratio 64:22) and the Matura grade (which is expected) are found to have a significant effect on these results. Similar results were obtained when examining the effect of variables on final grade results, as can be seen in Table 7 . Moreover, contrary to our expectations, the knowledge of other foreign languages did not have an effect on any of the results neither initial nor final (vocabulary, grammar, as well as final grade).

\begin{tabular}{|c|c|c|c|c|c|c|}
\hline & & & & & $\begin{array}{l}\text { Number of obs } \\
\text { F(5, 80) } \\
\text { Prob > F } \\
\text { R-squared } \\
\text { Adj R-squared } \\
\text { Root MSE }\end{array}$ & $\begin{array}{lr}= & 86 \\
= & 2.96 \\
= & 0.0166 \\
= & 0.1563 \\
= & 0.1035 \\
= & 16.442\end{array}$ \\
\hline Final_grade | & Coef. & Std. Err. & $t$ & $P>|t|$ & [95\% Conf & Interval] \\
\hline $\begin{array}{r}\text { Gender } \\
\text { Location } \\
\text { School } \\
\text { Otherlang } \\
\text { Matura_grade } \\
\text { cons }\end{array}$ & $\begin{array}{r}-8.789708 \\
2.29942 \\
-4.111709 \\
-1.17389 \\
6.079336 \\
56.891\end{array}$ & $\begin{array}{l}4.092807 \\
2.166934 \\
3.823879 \\
2.524826 \\
2.410018 \\
12.40417\end{array}$ & $\begin{array}{r}-2.15 \\
1.06 \\
-1.08 \\
-0.46 \\
2.52 \\
4.59\end{array}$ & $\begin{array}{l}0.035 \\
0.292 \\
0.285 \\
0.643 \\
0.014 \\
0.000\end{array}$ & $\begin{array}{r}-16.93465 \\
-2.012916 \\
-11.72147 \\
-6.198453 \\
1.283247 \\
32.20592\end{array}$ & $\begin{array}{r}-.6447627 \\
6.611756 \\
3.498052 \\
3.850673 \\
10.87543 \\
81.57608\end{array}$ \\
\hline
\end{tabular}

Table 7: Linear regression regarding final grade

\section{Conclusion}

In the design of LSP course curricula, LSP teachers continuously balance between teaching content-based learning and developing students' general language competencies in formal and informal communication. Based on our own experience as well as on the previous language experts' research and theories, we have focused both on target situation needs and learning needs: "Analysis of the target situation can tell us what people do with the language language use. What we also need to know is how people learn to do with what they do with the language - a learning centered approach to needs analysis" (Hutchinson \& Waters, 1987, p. 63). Therefore, our analysis may be seen as one 
step towards achieving this balance. In our analysis, students' progress regarding general language skills (grammar) and knowledge of business terms and concepts before and after the course was $74 \%$ and $20 \%$ respectively. Furthermore, our analysis of student needs based on initial and final testing results and the analysis of individual specific variables effect on these results have shown that contrary to our expectations, the only variable shown to be statistically significant as to student progress was the grade achieved at the English Matura exam. However, one-way ANOVA showed that even though there is no significant difference between schools regarding other variables, grammar school students showed slightly better results in all categories. One of the better side effects of our research is statistical evidence of a flawed grading system used at the University of Rijeka prior to the academic year 2018/2019. Namely, the distribution of final grades achieved upon the ESP course and those obtained at Matura showed rather high discrepancies whereas modified calculations using the new grading system showed similar distribution.

In order to further investigate student needs with the aim to develop LSP curricula meeting learning outcomes required by study programs it would be necessary to include data covering several generations which would allow for a more balanced sample and collection of data on different or additional individual specific variables such as motivation for the course/study, family educational background or hours dedicated to LSP courses.

\section{References}

Belcher, D. (2006). English for specific purposes: teaching to perceived needs and imagined futures in worlds of work, study and everyday life. TESOL Quarterly, 40, 133-156.

González, A., \& Joseba, M. (2013). (In)compatibility of CLIL and ESP courses at university. Language V alue, 5(1), 24-47.

Hutchinson T., \& Waters, A. (1987). English for Specific Purposes: A learning-centered approach. Cambridge: Cambridge University Press.

Marsh, D. (1994). Bilingual Education \& Content and Language Integrated Learning. Paris: International Association for Cross-cultural Communication, Language Teaching in the Member States of the European Union (Lingua), University of Sorbonne.

Upton, T. A. (2012). LSP at 50: Looking back, looking forward. Iberica, 23, 9-28. 


\title{
Fehler in schriftlichen Texten von Geschichtsstudenten als Ausgangspunkt für Fehlertherapie im berufsbezogenen Fremdsprachenunterricht
}

\author{
BRIGITA KACJAN \& BARBARA ŽIBRET
}

\begin{abstract}
Zusammenfassung Beim Erlernen einer Fremdsprache, auch einer berufsbezogenen Fremdsprache, kommt es oft zu Fehlern. Fehler können sehr unterschiedliche Ursprünge haben. Interferenzen als eine spezielle Form der Fehler entstehen bei der Übertragung einer bestimmten Eigenschaft einer bekannten Sprache auf die Zielsprache, wobei es zu einer Abweichung von der Norm kommt. Im Beitrag wird eine Untersuchung präsentiert, in der ausgewählte Fehlertypen in schriftlichen Texten von Geschichtsstudenten (Anfänger im Bereich DaF) untersucht wurden. Dabei wurden unterschiedliche Fehler, darunter vor allem Interferenzen aus dem Slowenischen (Muttersprache) und dem Englischen (erste Fremdsprache) analysiert. Solche Interferenzen sind meistens in der Orthographie, der Kasuszuordnung, der Verb- und Präpositionenverwendung, der Verwendung des Artikels und folglich der Generazuordnung bemerkbar. In der Untersuchung wurden kurze schriftliche Texte von Geschichtsstudenten bezüglich der sieben Interferenzbereiche slowenische Rechtschreibung, slowenische Lexik oder Semantik, slowenische Grammatik, englische Rechtschreibung, englische Lexik oder Semantik, englische Grammatik und Kleinschreibung der Substantive untersucht. Im Beitrag werden weiter die Quellen der identifizierten Fehler in den Aufsätzen näher bestimmt und Möglichkeiten aufgezeigt, die Entstehung solcher Fehler zu verhindern. Das Identifizieren dieser Möglichkeiten ist eine wichtige Kompetenz für jede (Fa-)DaF-Lehrkraft, da man bei einer Berücksichtigung dieser Fehler eine bessere bzw. korrektere Sprachproduktion und demzufolge einen schnelleren Spracherwerb bei den Lernenden erreichen kann.
\end{abstract}

Schlüsselwörter: ・ Interferenzen • Fehler • Deutsch als Fremdsprache • berufsbezogene Fremdsprache $\bullet$ schriftliche Texte $\bullet$

Über Den Autorinnen: Brigita Kacjan, Doz. Dr., DaF-Didaktik, Universität Maribor, Philosophische Fakultät, Maribor, Koroška cesta 160, 2000 Maribor, Slowenien, E-Mail: brigita.kacjan@um.si. Barbara Žibret, Absolventin des MA-Studiums; Deutsch als Fremdsprache und Unterrichten der englischen Sprache, Studentin, Universität Maribor, Philosophische Fakultät, Koroška cesta 160,2000 Maribor, Slowenien, E-Mail: zibret.barbara@gmail.com. 


\section{$1 \quad$ Einleitung}

Die Sprache gilt schon seit jeher als eines der wichtigsten Kommunikationsmittel, die eine Person verwenden kann. Da es viele verschiedene Sprachen auf der Welt gibt, wird man von allen Seiten dazu ermutigt, eine Fremdsprache zu lernen, um besser mit anderen kommunizieren zu können und unsere alltäglichen und fachlichen Ideen zu vermitteln. Eine Fremdsprache kann gesteuert oder ungesteuert gelernt werden. Beim Fremdsprachenunterricht in allgemeinbildenden Schulen kommt ausschließlich die erstgenannte Form des Sprachenlernens vor, da die Allgemeinsprache und ihre Regelungen systematisch durch die Lehrkraft vermittelt werden. Dies kann man als einen einschienigen Fremdsprachenunterricht bezeichnen. Wenn die Fremdsprache allerdings in einem berufsbezogenen Kontext erlernt wird, bspw. an einer Berufs- oder Fachmittelschule, und fachsprachliche Aspekte in den Fremdsprachenunterricht integriert werden, dann kann man das als einen zweischienigen Unterricht bezeichnen. Hier stehen sowohl die Fremdsprache als auch die Fachsprache gleichermaßen im Mittelpunkt.

Beim Erlernen einer Fremdsprache beobachten die Lernenden das fremde Sprachsystem mit Hilfe von allen vorher gelernten Sprachen, also der Muttersprache und den Fremdsprachen. Dabei stellen sie Hypothesen über die Zielsprache anhand ihres Vorwissens in ihrer Ausgangssprache auf und übertragen sie auf die Zielsprache. Einige Sprachen haben Ähnlichkeiten und bei solchen Sprachen ist ein großer Teil der Übertragungen erfolgreich. Dies wird als positiver Transfer verstanden. Allerdings kann es aber auch zu einem negativen Transfer zwischen den beiden Sprachen kommen, was in der Fremdsprachendidaktik als negativer Transfer oder Interferenz bezeichnet wird.

Im Beitrag werden Interferenzen zwischen der deutschen, slowenischen und englischen Sprache im Rahmen des studienbegleitenden FachDeutschunterrichts im Geschichtsstudium untersucht. Die Berücksichtigung solcher Fehler und der sprachtherapeutische Ansatz im Unterricht sind wichtige Faktoren für das erfolgreiche Erlernen einer Fremdsprache sowohl im allgemeinsprachlichen als auch im fachlichen Kontext. Auf diese Art wird die Sprachrichtigkeit gefestigt, was zu einem schnelleren Erlernen neuer Sprachelemente als auch zu einem besseren Verständnis der Sprache selbst führt. Außerdem können Lernende damit grundlegende Sprachmittel wie auch 
fachspezifische Terminologie und syntaktische Besonderheiten besser erkennen, sie verstehen und leichter verwenden.

\section{$2 \quad$ Untersuchungsdesign}

Im vorliegenden Artikel werden die sprachlichen Interferenzen im Rahmen von drei Sprachen untersucht. Dabei wird der Einfluss der slowenischen und englischen Sprache auf die deutsche Sprache der Fremdsprachenlernenden untersucht. Lernende werden beim Erlernen der deutschen Sprache nämlich sowohl von ihrer Muttersprache als auch ihrer ersten bzw. zweiten Fremdsprache beeinflusst, weswegen die Analyse nur auf diese zwei Sprachen eingegrenzt wurde. Einige Lernende könnten auch von anderen Sprachen beeinflusst werden, da man mit mehreren Sprachen im Alltag in Kontakt kommen kann.

Bei der vorliegenden Untersuchung wurden schriftliche Texte von Geschichtsund Kunstgeschichtestudenten analysiert. Diese Studierenden lernen Deutsch als studienbegleitende Fremdsprache. Sie haben bezüglich der Sprachen aber unterschiedliche Erfahrungen. Diese Erfahrungen entsprechen drei verschiedenen Sprachenprofilen:

A. Sprachenprofil SED (Slowenisch - Englisch - Deutsch): Studierende, deren Muttersprache Slowenisch, ihre erste Fremdsprache Englisch und ihre zweite Fremdsprache Deutsch ist.

B. Sprachenprofil SDE (Slowenisch - Deutsch - Englisch): Studierende, deren Muttersprache Slowenisch, ihre erste Fremdsprache Deutsch und ihre zweite Fremdsprache Englisch ist.

C. Sprachenprofil SE (Slowenisch - Englisch): Studenten, deren Muttersprache Slowenisch und ihre erste Fremdsprache Englisch ist. Sie haben Deutsch als ihre zweite Fremdsprache nie gelernt.

Natürlich gibt es auch im Rahmen dieser Profile Variationen, da die Studierenden unterschiedlich lang die Fremdsprachen Englisch und Deutsch gelernt haben und sie unterschiedliche Schultypen besucht haben. 


\section{$3 \quad$ Fehler}

Fremdsprachlernende machen beim Erlernen einer neuen Sprache immer Fehler. Das ist ein Teil des Lernprozesses, der nicht vermeidbar ist, da die Lernenden ihr Wissen über die Sprache testen. Aber was ist eigentlich ein Fehler? Sowohl Linguisten als auch Lehrer haben sich mit der Definition des Begriffs beschäftigt, allerdings kann man von keiner allgemeingültigen Definition sprechen. Kleppin (1998, S. 15-23) hat die verschiedensten Definitionen des Fehlers systematisch analysiert und in acht Definitionengruppen eingeteilt:

1. Fehler sind Abweichungen vom Sprachsystem.

2. Fehler sind Abweichungen von der geltenden linguistischen Norm.

3. Fehler sind Verstöße gegen die Ausdrucksweise und das Handeln in einer Sprachgemeinschaft.

4. Fehler sind alles, was ein Kommunikationspartner nicht versteht.

5. Fehler sind alles, was ein Muttersprachler nicht versteht.

6. Fehler sind alles, was gegen Regeln in Lehrwerken und Grammatiken verstößt.

7. Fehler sind alles, was ein Lehrer als Fehler bezeichnet.

8. Fehler sind alles, was ein Muttersprachler in einer bestimmten Situation nicht sagen oder tun würde.

Die Kontexte der Definitionen, die Kleppin bei der Zusammenstellung dieser Liste der Fehlerdefinitionsgruppen leiteten, sind für den vorliegenden Kontext nicht relevant und werden aus diesem Grunde auch nicht genauer dargelegt.

Da nicht alle angeführten Definitionengruppen für die Analyse von geschriebenen Texten verwendbar sind, wurde auf die Definition zurückgegriffen, die eine Analyse der verschriftlichten Fehler im vorgegebenen Untersuchungskontext möglich macht. Bei der vorliegenden Untersuchung werden Fehler als Abweichungen von der geltenden linguistischen Norm verstanden; diese Definition basiert auf allgemein anerkannten Fakten (die Norm ist schriftlich eindeutig festgelegt), die sich in verfassten Texten eruieren lassen. Für das Verständnis der Analyseresultate ist es aber auch wichtig zu verstehen, was Interferenzen sind. Diese Fehler sind zwar nicht die meist vertretene Art von Fehlern, aber sie sind sehr spezifisch und ihr Ursprung lässt sich bis zu einem 
gewissen Grad nachvollziehen, auch wenn die Verfasser der untersuchten Texte nicht als zusätzliche Informationsquelle dienen.

\section{$4 \quad$ Sprachliche Interferenzen}

\subsection{Begriffsdefinition}

Der Begriff sprachliche Interferenz wird in der Fachliteratur auf verschiedene Weisen definiert. Nach Petioky (1970, S. 63) ist Interferenz „die Verletzung einer sprachlichen Norm“. Diese Verletzung stammt aus dem Einfluss eines anderen Sprachsystems auf das Sprachsystem der Zielsprache. Diesen Einfluss einer Sprache an die andere nennt Lado (1971) auch Transfer, wobei es sowohl einen positiven als auch negativen Transfer gibt. Man spricht von einem positiven Transfer, wenn sich die Elemente aus der Ausgangssprache erfolgreich in die Zielsprache übertragen können. Das Gegenteil solcher Wirkung wird als negativer Transfer bezeichnet (Lado, 1971, S. 299). Man kann auch von einer interlingualen Interferenz sprechen, wenn man den wechselseitigen Einfluss der Zielsprache und der Muttersprache bzw. der schon gelernten Fremdsprache betrachtet. Diese Art von Interferenz bestimmt Weinreich (1977, S. 15) als „Abweichungen von der Norm“, die ein Ergebnis des Sprachenlernens des Individuums ist. Außerdem sollte erwähnt werden, dass es auch in der Zielsprache selbst zu Interferenzen kommen kann. Dabei stellen die Lernenden Hypothesen über die Sprache auf, die sie in ihrem Sprachgebrauch testen.

Im Rahmen der Untersuchung werden sprachliche Interferenzen als fehlerhafte und meist unbewusste Übertragungen der Elemente einer Sprache in die andere Sprache wegen des gegenseitigen Einflusses der Sprachen definiert. Der Grund für die Entstehung dieser Interferenzfehler ist die Kenntnis bzw. Unkenntnis der typischen Sprachstrukturen der Zielsprache. Im Jahr 1967 hat Corder solche Fehler als Performanz- und Kompetenzfehler klassifiziert. Bei Performanzfehlern komme es zu Fehlern beim Gebrauch der Sprache in einer bestimmten Situation, die der Lernende auch selber erkennen und korrigieren könne, da er das Wissen dafür habe. Bei Kompetenzfehlern habe der Lernende noch nicht genug Wissen über die Zielsprache, dass er seinen Fehler korrigieren könnte. Deswegen zeigen diese Fehler den konkreten Lernstand des Lernenden. Nach dieser Betrachtung der Kompetenz- und Performanzfehler sei ersichtlich, dass Interferenzfehler beide Arten von Fehlern sein können. Nur mit einer 
genaueren Untersuchung der einzelnen Interferenzfehler könne der Beurteiler entscheiden, welche der beiden Klassifikationen im bestimmten Fall vorhanden sei (Oksanen, 2014).

\subsection{Interferenzbereiche}

Nachdem Interferenzen als eine spezifische Art von Fehlern definiert bzw. bestimmt wurden, müssen sie in einer sinnvollen Art und Weise systematisiert werden, um sie diagnostizierbar, also analysierbar und interpretierbar zu machen und auf dieser Grundlage didaktische Schlussfolgerungen ziehen zu können Interferenzfehler also in gewisser Weise auch therapierbar zu machen. Um diese Schritte gehen zu können (Fehlerdiagnose, -analyse und -therapie), wurde von Kacjan (2013) eine sogenannte Liste der Interferenzbereiche bestimmt, die sich als ein anwendbares Instrument zur Analyse von Interferenzfehlern erwies und auf deren Grundlage die vorliegende Untersuchung durchgeführt wurde.

Nach Kacjan (2010) gibt es sieben Interferenzbereiche, die auf der Grundlage der linguistischen Normen der ausgewählten Sprachsysteme gebildet wurden: slowenische Rechtschreibung, slowenische Lexik bzw. Semantik, slowenische Grammatik, englische Rechtschreibung, englische Lexik bzw. Semantik, englische Grammatik und Kleinschreibung der Substantive. Der zuletzt erwähnte Interferenzbereich bildet eine besondere Gruppe von Interferenzen, da ihr Ursprung in der vorliegenden Sprachenkonstellation nicht wirklich nachvollziehbar ist, d. h. es kann nicht nachvollzogen werden, ob die Kleinschreibung von Substantiven der geltenden Norm im slowenischen oder Englischen zuzuschreiben ist. Diese im Weiteren skizzenhaft beschriebenen Interferenzbereiche bilden die Grundlage dieses Artikels (Mulej \& Kacjan, 2013, S. 21).

Interferenzbereich 1: Slowenische Rechtschreibung

$\mathrm{Zu}$ diesem Bereich zählen die deutschen Wörter, die nach den Regeln der slowenischen Rechtschreibung geschrieben werden, und die deutschen Wörter, die auf der Basis der slowenischen Aussprache geschrieben werden. Beispiele: *zehr statt sebr, *fohrlesungen statt Vorlesungen, *werscheinlich statt wahrscheinlich, usw. 
Interferenzbereich 2: Slowenische Lexik oder Semantik

Bei dieser Art von Interferenz werden slowenische Wörter, oder Abwandlungen dieser, beim Schreiben oder Sprechen verwendet oder slowenische Wörter falsch ins Deutsche übersetzt. Beispiele: *klobas statt Wurst, *Ubr statt Stunden, *kuchen statt kochen, usw.

Interferenzbereich 3: Slowenische Grammatik

Die slowenische Grammatik hat spezifische Eigenschaften wie zum Beispiel die Reihenfolge der Wörter in einem Satz bzw. die slowenische Syntax. Somit werden diesem Bereich alle Interferenzen zugeordnet, in denen eine deutlich erkennbare slowenische Ausdrucksweise, die die grammatischen Regeln der slowenischen Sprache aufweisen, erkennbar ist. Beispiele: *..., wo *kriegt man das Geld, im Slowenischen: k.jer dobimo denar; sein Mund ${ }^{*}$ sind groß, im Slowenischen: njegova usta so velika; er hat *in kleiner Nase, im Slowenischen: on ima majhen nos, usw.

Interferenzbereich 4: Englische Rechtschreibung

Ähnlich wie beim ersten Bereich werden auch hier die deutschen Wörter entweder nach den Regeln der englischen Aussprache oder nach den Regeln der englischen Rechtschreibung geschrieben. Beispiele: *Music statt Musik, * ${ }^{*}$ off statt Kaffee, *Hat bzw. Haat statt Hut, usw.

Interferenzbereich 5: Englische Lexik oder Semantik

Dieser Bereich wird vom Gebrauch englischer Wörter charakterisiert, die dann in einem gesprochenen oder geschriebenen Text falsch übersetzt wurden. Zahlreiche dieser Wörter sind sogenannte „falsche Freunde“, die englische Wörter darstellen, die ähnlich wie deutsche Wörter geschrieben werden, aber eine ganz andere Bedeutung tragen. Beispiele: *Croatia statt Kroatien, *game statt Spiel, *Skirt statt Rock, usw. 
Interferenzbereich 6: Englische Grammatik

Hier wird die englische Ausdrucksweise, englische Syntax und der Gebrauch der grammatischen Regeln des Englischen beim Schreiben oder Sprechen in der deutschen Sprache in den Vordergrund gestellt. Beispiele: *gelösed statt gelöst, *Danach ich habe *frübstuck, im Englischen: Then I have breakfast; *Zuerst, ich wasche mich, im Englischen: First, I wash myself, usw.

Interferenzbereich 7: Kleinschreibung der Substantive

Diese Art von Interferenz kann nicht direkt dem Einfluss des Slowenischen oder Englischen zugeordnet werden, da beide Sprachen dieselbe Eigenschaft haben, d. h., dass die Substantive kleingeschrieben werden. In diesem Bereich gibt es bei den Lernenden auch die meisten Fehler. Beispiele: *bund statt Hund, *name statt Name, *Aßstatt a $\beta$, Alt statt alt, usw.

\section{$5 \quad$ Untersuchung}

\subsection{Fehleranalyse}

Die Fehleranalyse ist für die Spracherwerbforschung und den Fremdsprachenunterricht sehr wichtig. Durch eine Fehleranalyse werden Fehler identifiziert, klassifiziert und beschrieben. Die Fehleranalyse als Instrument kann Lehrkräften helfen Lernschwierigkeiten zu bestimmen und sie im Weiteren zu verhindern (Kuhs, 1987, S. 175-176).

Bei der Untersuchung wurden kurze schriftliche Texte der Geschichtsstudenten analysiert, die Anfänger im Bereich Deutsch als Fremdsprache sind. In diesen Texten wurden sprachliche Interferenzen identifiziert, da gezeigt werden soll, wie viele und welche Arten von Interferenzen am häufigsten vorkommen. Diese Interferenzfehler wurden dann herausgeschrieben und einem der sieben Interferenzbereiche zugeordnet. Im Falle, dass es mehrere Interferenzfehler in einem Wort oder Satzteil gab, wurde der Fehler allen betroffenen Bereichen zugeschrieben. 


\subsection{Analyseresultate und Diskussion}

Die Untersuchung wurde anhand von Texten, die von Geschichtsstudenten des ersten und zweiten Jahrgangs des Einzelfachstudiums an der Philosophischen Fakultät in Maribor geschrieben wurden, erstellt. Somit wurden 70 Texte untersucht, die sowohl allgemeine Themen wie Familie als auch geschichtliche Themen wie das Leben einer bekannten Person aus der Geschichte enthielten. Diese Texte mit 30 bis 60 Wörtern wurden von den Studenten als Teil von Prüfungen verfasst.

Die erstellten Texte wurden zuerst auf alle Arten von Fehlern hin analysiert. Dabei wurden sie systematisch nach den Bereichen Rechtschreibung, Grammatik und Lexik/Semantik geordnet. Daraufhin folgte die Identifizierung sog. Interferenzfehler und eine zweite Systematisierung dieser Fehler bezüglich der sieben Interferenzbereiche. In einem nächsten Schritt wurden dann die Interferenzfehler nach ihrem Umfang und ihrer Art näher untersucht.

Die wichtigsten Analyseresultate werden in diesem Kapitel mithilfe von Diagrammen präsentiert. Alle Angaben sind in Prozenten angegeben. Zuerst wird der Anteil der Interferenzfehler mit dem Anteil anderer Fehler, die in den analysierten Texten vorkommen, in Beziehung gesetzt. Dann wird der Anteil der Interferenzfehler in Bezug auf die vorgestellten Interferenzbereiche beschrieben. Zum Schluss werden einzelne Interferenzfehler in Zusammenhang mit den Interferenzsprachen besprochen.

Um einen Einblick in den Anteil der Interferenzfehler im Vergleich zu anderen Fehlern in den Texten zu bekommen, wurde ein Diagramm dafür hergestellt. Wie aus dem Diagramm 1 ersichtlich ist, stellen Interferenzfehler nur 27,1\% aller Fehler dar. Das bedeutet, dass die Studierenden eines berufsbezogenen Fremdsprachenunterrichts mehr allgemeine Fehler, die nicht der Interferenz der slowenischen oder englischen Sprache zuzuordnen sind, machen. Diese Fehler sind in meisten Fällen Kompetenzfehler, es kommen aber auch Performanzfehler vor, eine genauere Aufschlüsselung beider Fehlerarten ist für den vorliegenden Beitrag nicht relevant und deshalb wird nicht näher darauf eingegangen. 
Anteil der Interferenzfehler und anderer Fehlerarten

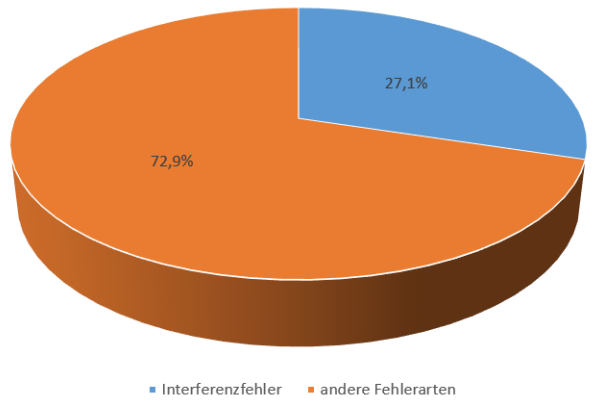

Diagramm 1: Anteil der Interferenzfehler und anderer Fehlerarten

Im Tortendiagramm (Diagramm 2) werden die gefundenen Interferenzfehler anhand ihres Anteils an den verschiedenen Interferenzbereichen dargestellt. Dabei wurden die Rechtschreib-, Grammatik- und Lexikfehler, die den Einfluss der slowenischen und englischen Sprache aufzeigen, zusammengefasst. Dem Diagramm ist zu entnehmen, dass die Geschichtsstudenten die meisten Interferenzfehler bei der Grammatik machen, da der Anteil solcher Fehler bei 40,6 \% liegt. Auf dem zweiten Platz liegt der Interferenzbereich der Kleinschreibung der Substantive, dessen Anteil 33,6 \% beträgt. Der Anteil der Rechtschreibfehler, die die Interferenz des Slowenischen und Englischen aufzeigt, macht

22,4 \% der gesamten Interferenzfehler aus. Zuletzt kann man den Anteil der Lexikfehler mit 3,4\% im Vergleich zum Gesamtwert als relativ gering betrachten.

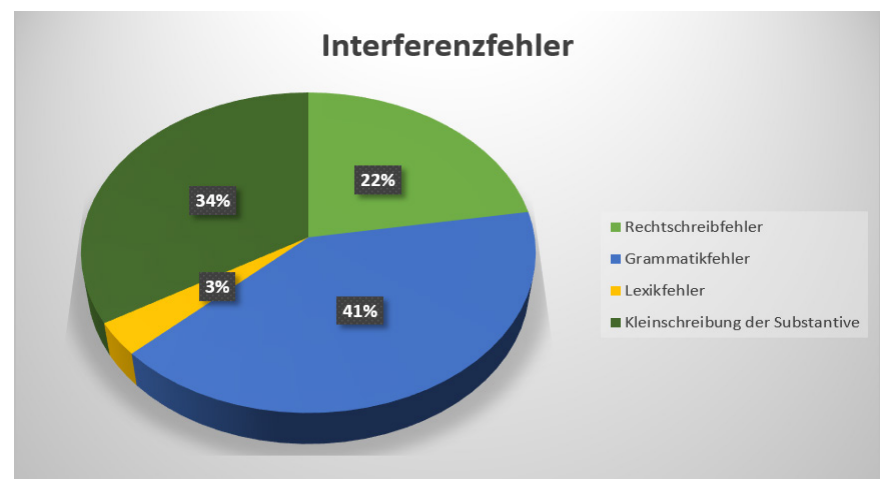

Diagramm 2: Interferenzfehler in den Interferenzbereichen 
Aus dieser allgemeinen Übersicht lässt sich herauslesen, dass gut drei Viertel aller festgestellten Interferenzen dem Bereich der Rechtschreibung zuzurechnen sind, da die Kleinschreibung der Substantive ebenfalls zu den Rechtschreibfehlern gehören. Aufgrund ihres gehäuften Auftretens und der nicht ganz eindeutigen Zuordnung der Fehlerursache zu einer bestimmten Sprache werden diese Interferenzen aber als eine gesonderte Kategorie behandelt.

Aus dem Diagramm 2 lässt sich nicht ersehen, welchen Anteil die Interferenzen der englischen und slowenischen Sprache jeweils haben, deswegen werden im Folgenden die erhaltenen Resultate noch weiter aufgeschlüsselt.

Diagramm 3 gibt Auskunft über den Anteil der slowenischen und englischen Interferenzen unter den Grammatikfehlern. Der Anteil der Interferenz der slowenischen Grammatikregeln ist mit 77,6 \% aller Grammatikfehler am größten. Dabei stellt die Auslassung des bestimmten oder unbestimmten Artikels (dieser Fehler kommt 35-mal vor) den größten Teil der Fehler, was den Einfluss der slowenischen Sprache gut darstellt, da diese keine Artikel verwendet, während das Englische sehr wohl Artikel verwendet, wenn auch in einer stark eingeschränkten Form (den bestimmten Artikel the und den unbestimmten Artikel $a / a n)$.

\section{GRAMMATIKFEHLER}

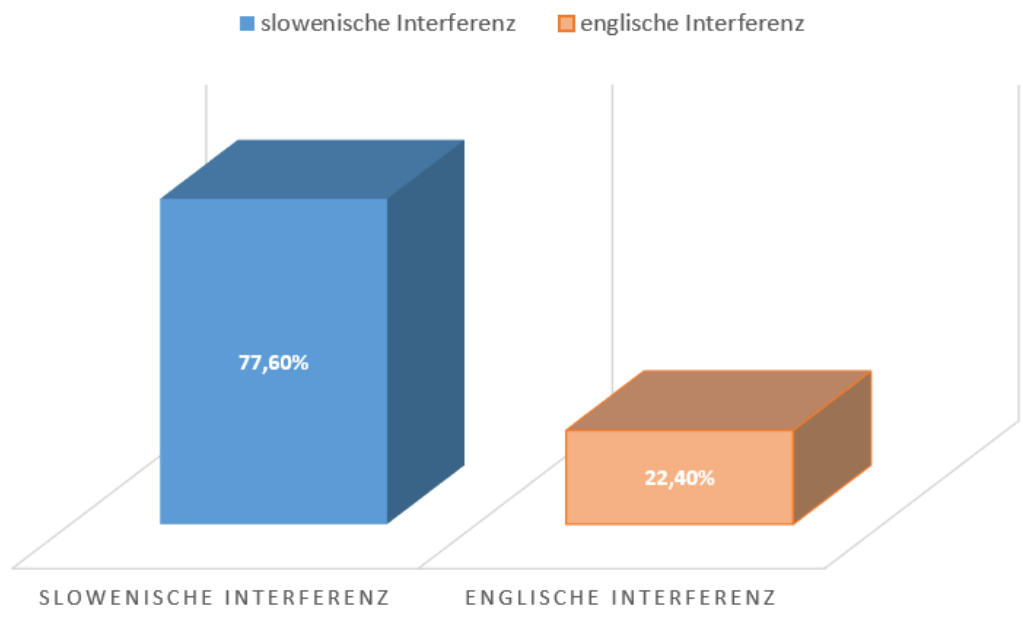

Diagramm 3: Interferenzfehler im Bereich der Grammatik 
Andere Fehler, die hier zu erwähnen wären, sind ein falsches Genus der Substantive (z. B. „*Der Nase ist groß“, da dieses Substantiv im Slowenischen das männliche Geschlecht hat, während es im Deutschen weiblichen Geschlechts ist) und eine falsche Verbform in Verbindung mit dem Substantiv (z. B. „sein Mund $*_{\text {sind }}$ groß ${ }^{\prime}$, da dieses Substantiv im Slowenischen nur die Pluralform hat, während es im Deutschen Singular ist). Im Vergleich zu den slowenischen Interferenzfehlern im Bereich der Grammatik ist der Anteil der englischen Interferenzen niedriger und beträgt 22,4\%. Hier kommen Fehler wie eine falsche Satzgliedfolge in einem Satz vor (z. B. „Zuerst, ich wasche mich“, was gut aus dem Englischen übernommen sein könnte von „*First, $I$ wash myself“ und die Charakteristik der Sprache aufzeigt) und die Verwendung einer falschen Konjunktion (z. B. , ${ }^{*} W a n n$ ich nach Hause kam, ging ich spazieren.“, was direkt aus dem Englischen „When I came home, I went for a walk“ übersetzt sein kann).

Das Diagramm 4 zeigt den Anteil der Fehler bei der Kleinschreibung der Substantive und Großschreibung anderer Wortarten. Im Rahmen dieses Bereiches waren Fehler, bei denen das Substantiv kleingeschrieben wurde, bedeutend häufiger als Fehler, bei denen andere Wortarten großgeschrieben wurden. Somit betrug der Anteil der kleingeschriebenen Substantive 85,4 \% und der Anteil anderer großgeschriebenen Wortarten 14,6 \%. Die Wörter, die am häufigsten groß- und nicht kleingeschrieben wurden, waren Adjektive (z. B. $*$ Schlank und $* A(t)$.

\section{KLEINSCHREIBUNG/GROSSSCHREIBUNG}

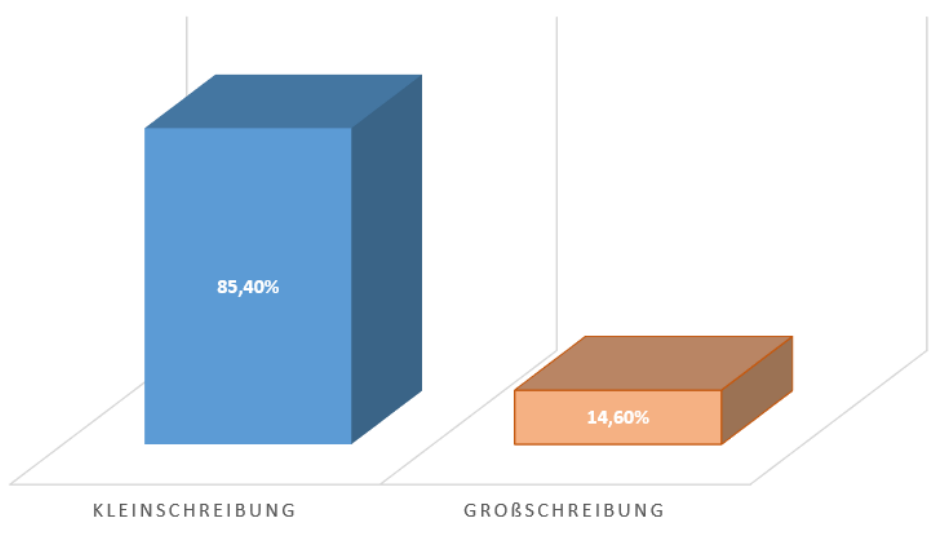

Diagramm 4: Interferenzfehler im Bereich der Kleinschreibung/Großschreibung 
Diese Fehler sind relevant, da sie die Rechtschreibregeln beider Sprachen, sowohl des Slowenischen als auch Englischen, beachten. Bei beiden Sprachen werden nämlich Substantive klein geschrieben, weswegen sie wahrscheinlich auch bei diesen Texten der Geschichtsstudenten so geschrieben worden sind. Allerdings haben die Lernenden gelernt, dass Substantive im Deutschen großgeschrieben werden. Da sie aber nicht wissen, welche Wörter Substantive sind, schreiben sie irgendwelche Wörter groß. Somit kommt es zum Fehler der Großschreibung anderer Wortarten.

Aus dem Diagramm für Interferenzen im Bereich von Rechtschreibfehlern (Diagramm 5) ist ersichtlich, dass Interferenzen des Slowenischen häufiger waren als Interferenzen des Englischen.

\section{RECHTSCHREIBFEHLER}

घ slowenische Interferenz $\quad \square$ englische Interferenz

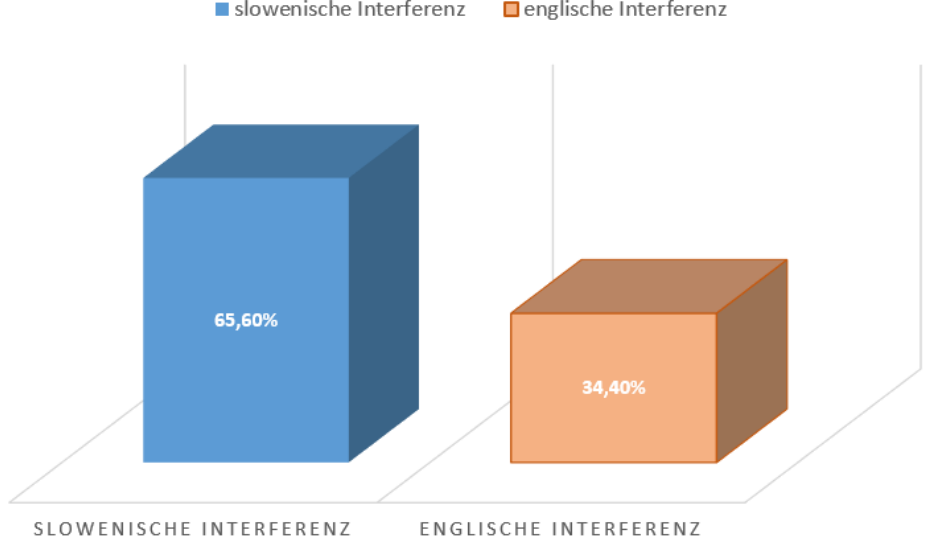

Diagramm 5: Interferenzfehler im Bereich der Rechtschreibung

Der Anteil der slowenischen Interferenz in diesem Bereich beträgt 65,6 \%, wobei der Anteil der englischen Interferenz 34,4 \% beträgt. In beiden Fällen war die spezifische Schreibweise der einzelnen Sprachsysteme im Vordergrund. Dabei wurden bei den slowenischen Interferenzen Wörter nach slowenischen Schreibregeln geschrieben (z. B. *werscheinlich statt wahrscheinlich und *mitelange statt mittellange). Außerdem wurden bei den englischen Interferenzen Wörter nach englischen Schreibregeln geschrieben (z. B. *Yahre statt Jahre (engl. years) und *Slowenia statt Slowenien (engl. Slovenia). 
Beim letzten Interferenzbereich Lexik kann man beobachten (siehe Diagramm 6), dass die englischen Interferenzen bei der Lexik/Semantik mit $60 \%$ (z. B. *game statt Spiel und *Skirt statt Rock) im Vergleich zum Anteil der slowenischen Interferenzen, die $40 \%$ betrugen (*kuchen statt kochen (slov. kuhati $=$ kochen) und $* U h r$ statt Stunden (slov. ura $=$ Uhr und Stunde)), deutlich häufiger vertreten waren. Hier wurden Wörter aus den einzelnen Sprachen falsch ins Deutsche übersetzt. Derartige Übersetzungsfehler kann man am besten mit dem Wort „kuchen“ für kochen illustrieren, da dieses Wort im Slowenischen „kuhati“ heißt.

\section{LEXIKFEHLER}

- slowenische Interferenz $\quad \square$ englische Interferenz

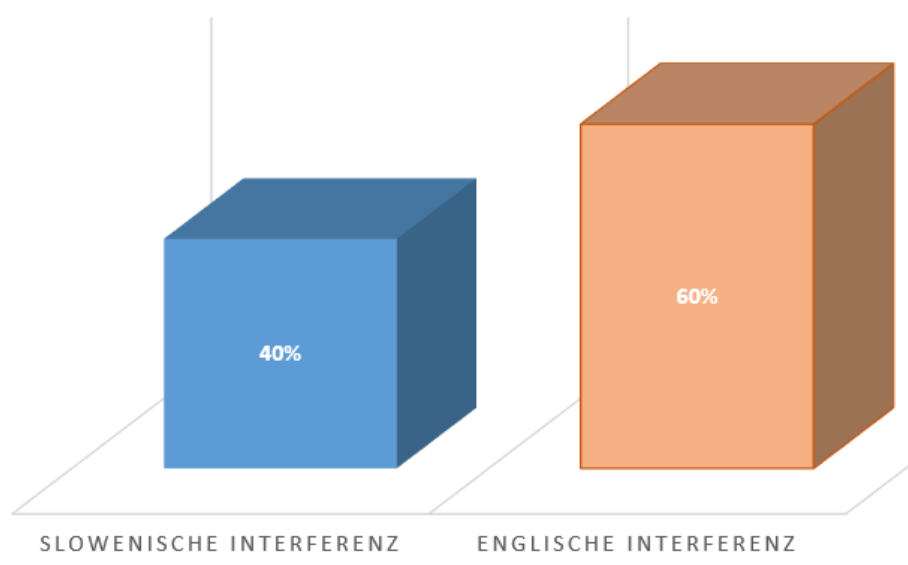

Diagramm 6: Interferenzfehler im Bereich der Lexik 


\section{Schlussfolgerungen bzw. Möglichkeiten der Fehlertherapie}

Nachdem die Fehler diagnostiziert und zusammen mit den Studierenden in Bezug auf die Entstehungsgründe analysiert wurden, ist der nächste Schritt die Fehlertherapie. Fehlertherapie bedeutet im vorliegenden Kontext, dass die Studierenden gezielt auf die identifizierten Interferenzfehler aufmerksam gemacht werden. Dieser Teil der Theorie der Sprachbewusstheit ist auch im fachorientierten DaF-Unterricht ein bedeutender Aspekt, dem allerdings oft keine oder nur unzureichende Aufmerksamkeit geschenkt wird. Um dies zu beheben, können sich DaF-Lehrkräfte an folgende Richtlinien halten:

1. Da jeder Lernende Fehler macht, die für ihn spezifisch sind, ist eine Individualisierung des Lernprozesses bei der Fehlertherapie notwendig. Somit bekommt jeder Lernende Rückmeldung über seine Schwierigkeiten beim Erlernen der Fremdsprache und wie er sie vermeiden kann.

2. Die Interferenzfehler, die typisch für viele Lernende sind, sollen im Unterricht angesprochen werden, damit sie bewusstgemacht werden, und infolgedessen ihre Behebung gezielt geübt werden kann.

3. Für die Grammatikfehler, die am häufigsten vorgekommen sind, müssen den Lernenden Erklärungen und Hilfestellungen gegeben werden, wie sie der Lernende in der Zukunft vermeiden kann.

4. Im Fall der Rechtschreibfehler wäre es empfehlenswert, dass so viel wie möglich im Unterricht oder auch als Hausaufgabe geschrieben wird, wobei sowohl die Allgemeinsprache wie auch die Fachsprache vorhanden sein sollte. Bei der Rückmeldung durch die Lehrkraft werden die alten bzw. neuen Fehler in den Texten immer wieder identifiziert und durch Übungen therapiert.

Diese Vorschläge für die Fehlertherapie verwandeln den bisher als zweischienig bezeichneten Unterricht in einen modifizierten zweischienigen Unterricht, da unter diesen Umständen im fachorientierten $\mathrm{DaF}$-Unterricht in den beiden Bereichen Allgemeinsprache und Fachsprache auch die Fehlertherapie ihren Anteil am Unterrichtskonzept fordert. Auf diese Art und Weise ist es jeder/jedem Lernenden ermöglicht, sich gezielter und selbstbestimmter mit dem 
eigenen Sprachenlernprozess auseinanderzusetzen und ihr/sein sprachliches Wissen effizienter einzusetzen.

\section{Literatur und Quellen}

Kacjan, B. (2010). Sprachen übergreifender Transfer im DaF-Unterricht als Lernchance und Lebrverpflichtung - Bestandsaufnabme in Slowenien. In Germano-Slavica: a Canadian journal of Germanic and Slavic comparative and interdisciplinary studies, 17, 71103.

Kleppin, K. (1998). Febler und Feblerkorrektur. Fernstudieneinheit 19. München: GoetheInstitut.

Kuhs, K. (1987). Febleranalyse am Schülertext. In Gesteuerter Zweitspracherwerb. Ernst Apeltauer (Hrsg.). München: Huber.

Lado, R. (1971). Moderner Sprachunterricht. Eine Einfübrung auf wissenschaftlicher Grundlage. 3. Aufl. München: Hueber Verlag.

Mulej, S., \& Kacjan, B. (2013). Analiza napakv nemških strokovnih besedilih slovenskih študentov tehnike kot posledica upliva drugih jezikov. In Schaurein: praxisorientierte Zeitschrift der slowenischen Deutschlehrer. Nr. 1. Maribor: SDUNJ.

Oksanen, L. (2014). Wer kann diese beherrschen? Eine vergleichende Analyse der Verbrektionsfehler finnischer DaF-Lernender. Universität Tampere. Abgerufen von: https://tampub.uta.fi/bitstream/handle/10024/96163/GRADU1412859337.pdf?sequence $=1$

Petioky, V. (1970). Interferenzen beim Übersetzen und Dolmetschen zwischen Russisch und Deutsch. In Internationaler Verband der Lehrkräfte der russischen Sprache und Literatur: Interferenzen der deutschen Muttersprache beim Russischunterricht. Wien/Düsseldorf.

Weinreich, U. (1977). Sprachen in Kontakt. München: C.H. Beck Verlag 


\title{
Autonomous AND/OR Dependent: Learning for Success
}

\author{
IVA LUČEV
}

\begin{abstract}
The aim of this paper is to demonstrate the importance of autonomous learning, outside (but also inside) the language classroom, and in the lifelong run. Within reach of the study, this field will be approached by employing a questionnaire to correlate the students' own perception of autonomy on the one hand and the so-called teacher dependence (formal context for learning) on the other. Furthermore, it will attempt to interact and possibly connect the two concepts with the students' measurable academic achievement (final grades) in an effort to shed light on how the students' learning habits and backgrounds, as well as formality preferences come together to form academic success or failure. The study will further pursue to show whether the students' perceptions of autonomy and dependence are necessarily opposed or if there is a relevant meeting point of the two traditionally antonymous concepts.
\end{abstract}

Keywords: - learner autonomy $\cdot$ teacher dependence $\cdot$ content dependence $\bullet$ academic success $\bullet$ out-of-class learning $\bullet$

CORRESPONDENCE ADDRESS: Iva Lučev, MA, Foreign Language Instructor, Dag Hammarskjöld University College of International Relations and Diplomacy, Filipa Vukasovića 1, 10000 Zagreb, Croatia, e-mail: ivalucev@gmail.com. 


\section{$1 \quad$ Introduction}

The foreign language classroom of today, and especially one in tertiary education, is under justifiable scrutiny. Practitioners and scientists alike have been wondering if the established student-teacher exchange dynamics ought to be transformed. This suspicion has arisen almost half a century ago, when Henri Holec posed the question of learner autonomy, defined as the "learner's ability to be responsible for his/her learning" (Oxford, 2003, p. 75). The importance of learner autonomy is becoming increasingly compelling in all learning contexts, both formal and informal, and on all levels (primary, secondary and tertiary), as research has given rise to the so-called learner-centred classroom: "The idea of autonomy in language learning is often represented as a radically learner-centred idea. It has evolved over the past thirty years or so" (Benson, 2008, p. 16). Admittedly, this ability is particularly crucial in adult education as it is seen as continuation of formal, compulsory study, a step toward lifelong learning and operational independence. Since the participants of the study presented in this paper were all adult learners, namely students of the undergraduate study of international relations and diplomacy at the Dag Hammarskjöld University College in Zagreb, the topic of language learning in the wider context of learner autonomy seemed especially important and closely bound - knowing a foreign language, and particularly in the field of international relations, will undoubtedly help them find meaningful employment and belong in the target community. To quote David Little: "Communicative efficiency in the target language community depends on learners having the independence, self-reliance and self-confidence to fulfil the variety of social, psychological and discourse roles in which they are cast. It depends, that is to say, on their achieving a substantial degree of autonomy as language users" (Little, 1991, p. 27). Even more to the point, the importance of proficiency in English is paramount. The role of the teacher is thus to prepare her students for the demands of the globalized world, where it is almost redundant to emphasize the vital role of fluency in the English language as lingua franca.

It goes without saying that autonomy is an invaluable asset in all pursuits of knowledge, especially nowadays when we are all expected to become students of the lifelong school. "The basic premise of this argument is that the idea of 'autonomy in learning', which takes a subject specific form in the idea of 'autonomy in language learning', is essentially a construal of the relevance of broader ideas of 'autonomy in life' to issues of teaching and learning" (Benson, 
2008, p. 16). Nonetheless, learning a foreign language can be said to be somewhat particular to other types of learning. The aim of this paper is to explore if tertiary level students are aware of the importance of autonomy in learning English. In this light, we will attempt to find answers to the question whether an awareness of the importance of autonomous learning, operationalized here mostly as extracurricular activity, and teacher (in)dependence in the classroom, is related to the students' academic success. What is more, we will try to link the two concepts - autonomy in foreign language learning and teacher (in)dependence - to see whether they correlate differently to the students' final grades.

\section{$2 \quad$ Idea}

Conventionally, autonomy in learning (a foreign language) and teacherdependent behaviour in the classroom are virtually seen as antonyms, and unquestionably that is most commonly the case, as autonomy and independence overlap both semantically and practically. When we speak of autonomy in learning, we mostly concentrate on extracurricular engagement, in other words, how students approach their learning "beyond the classroom". As Phil Benson distinguishes it (Benson, 2011, p. 9): "In discussing the scope of the field, we are also faced with a number of alternative terms that we have largely chosen to avoid here in favour of the more inclusive term language learning beyond the classroom'. These include 'out-of-class', 'out-of-school', 'after-school', 'extracurricular' and 'extramural'; 'non-formal' and 'informal'; 'self-instructed', 'non-instructed' and 'naturalistic'; 'independent', self-directed' and 'autonomous' language learning - terms which point to those four distinct dimensions of language learning beyond the classroom - location, formality, pedagogy and locus of control" (boldface by author). It is clear that "the field" (autonomy in language learning) abounds in terminology, which all relatively reliably tends toward a concordant concept. In our opinion, this does not create confusion, on the contrary, it provides the necessary delineation and clarification of the various aspects of foreign language learning. Nevertheless, we will here continue to use the term autonomy as it is most transparent, both in literature and in application. Teacher-dependence, on the other hand, is seen as counterproductive reliance upon the teacher, mostly in a teacher-directed classroom, where the students are not expected to be responsible for their learning, make their own decisions concerning learning activities, plan and manage the activities, but rather expect the teacher to coordinate the process of learning, exerting authority. 
Autonomy is, thus, seen as productive, while teacher-dependence is seen as counter-productive to learning, and logically so. Both types of behaviour, nevertheless, are often seen in the classroom, one not necessarily excluding the other, which will be further hypothesized in the paper. The author has seen a number of students who could not overcome the feeling of the language classroom as obligatory, compulsory, non-voluntary, and rigid, "others-created", despite their familiarity with formal classroom learning (Oxford, 2003). They were extrinsically motivated only to score highly in examinations. On the other hand, there were students who, entirely self-taught but highly intrinsically motivated, managed to shape themselves into perfect, yet highly dependent learners. Both groups have had some initial difficulty adjusting to the new learning demands, some as more dependent upon the teacher, some less, but there has been very little regularity on their respectable paths toward academic success (or failure). In other words, it has been impossible to find predictability from their learning histories to final academic achievement. It is the author's opinion that, while exhibiting dependent behaviour in the classroom, some students have considerable autonomy "beyond the classroom". To compensate for the lack of comfort and familiarity with a formal learning setting (a learning circumstance, formalized by a set curriculum, learning outcomes, designated leadership and compulsory examination), such individuals need to rely on a figure of authority to offer guidance through the explicitly academic context, for example, by providing correct answers, spelling very precise instructions, suggesting essay or presentation topics, etc. Even though they can perform all the tasks accurately and competently, the teacher still needs to supply a framework of explanations. In point of fact, such behaviour can be depicted as dependent, or overtly reliant, but still, not as counter-productive. On the contrary, the students in question are often very responsible and ultimately successful, in terms of '"proactive' and 'reactive' autonomy, which relates autonomy more directly to an organizational setting: the former term refers to full individual autonomy, and the latter to an ability to fulfil the responsibilities put on one by an organization (either directly or through the teacher)" (Palfreyman, 2003, p. 184). They are the meeting point of autonomy, dependence and academic success. However, since no learning histories were collected to provide support, this hypothesis is based on a hunch and formulated upon rare casual conversations and occasional glimpses into the students' lives "beyond the language classroom" (Benson, 2011). Out of this peculiarity then arose an interest to look more closely into the topic of autonomy in learning, weighed against (and 
not in favour of) teacher independence in a classroom environment. The question is whether a sense of autonomy outside the language classroom beyond the walls of academia - necessarily extends into the classroom, or in other words, if a formally successful student (measured in academic grades) may fail spectacularly when he or she is expected to take matter into their own hands.

To explore if such behaviour can be scientifically tested, the author has devised a short questionnaire (27 items) to be employed for the purposes of the study. It has been assembled in such a way to inquire about the three distinct concepts in question: self-perception of autonomy, self-perception of teacher (in)dependence, and the students' final grades (English language 1 through 4 compulsory foreign language courses at the undergraduate level). All questions but the final one, in which the students are asked to provide their (numerical) final grades, require answers formulated upon a Likert-type attitude scale. The immediate intention of the study was to see whether the participants' $(\mathrm{N}=52)$ answers would point to a reciprocity of autonomy in learning and dependent behaviour in the classroom, respectively, to academic achievement, or final grades. Only secondarily did it attempt to unjoin the first two categories and correlate them separately in order to look for potential interactions between autonomous and dependent behaviour.

\section{Research}

The questionnaire designed for the study examines how the students perceive their own autonomy in learning English. But, to quote Benson once again, "from the teachers' perspective, autonomy is primarily concerned with institutional and classroom learning arrangements within established curricula. In other words, from the teachers' perspective, autonomy tends to imply the learner taking control of arrangements whose underlying legitimacy is unquestioned. From the learners' perspective (which I view as tangential to, rather than opposed to, the teachers' perspective), autonomy is primarily concerned with learning, in a much broader sense, and its relationship to their lives beyond the classroom" (Benson, 2008, p. 15). It follows then that the questionnaire attempts to mirror the two perspectives: the teacher's and the learners'. It is the teachers too who ought to reflect on and re-examine their roles as (sole) purveyors of linguistic content and position themselves relative to their students' language learning histories and preferences, in both curricular and extracurricular settings (Gholami, 2016). In determining the students' language learning habits and preferences, we examine 
how they acquire and shape habits to consume (linguistic) content in L2 seen as a leisurely activity; if they are motivated to improve L2 through extracurricular conscious linguistic effort; if they are aware of their learning in terms of planning activities and consciously using strategies; if they are familiar with self-reflection; if they are confident in their own study plans and learning strategies; if they perceive themselves as teacher-dependent or content-dependent, etc. (Trebbi, 2008; Macaro, 2008).

The questionnaire consists of 27 items, roughly divided into three categories: autonomy, dependence and academic success. Furthermore, for the questionnaire to yield more transparent results in terms of statistical analysis, the items have been grouped subsequently into for distinct categories - autonomy seen as a leisurely activity (e.g. I read books in English forpersonal pleasure/ leisure; How often do you communicate with foreigners in English on social networks, gaming platforms or via e-mails) and as a study plan (e.g. I download and use dictionary and language tool apps on my smartphone; When I practice my English outside classroom requirements I notice my language skills are improving), as well as dependent behaviour in both curricular (e.g. I wait for the teacher's instructions for classroom assignments and exercises even though there are written instructions available beforehand; I ask the teacher for suggestions for presentation topics and literature) and extracurricular (e.g. I take the teacher's advice to improve my English out of class by writing practice personal statements, resumes and letters of intent to pretend (or real) future employers) settings. The final group of questions, roughly called extracurricular dependence, might seem rather illogical and hence require additional explanation. Its aim was to explore the students' content dependence, that is to see whether the students perceive their out-of-class learning as a continuation of classroom learning, if they recognize an activity as a learning activity only if it is connected to the formal context they know - the teacher and the content.

We believe these parameters might help the students make more sense of their learning, both conscious and unconscious, as well as help practitioners and scholars alike understand the current position of foreign language teaching. More specifically, the questionnaire might afford us a glimpse "beyond the language classroom" in order to weigh the general reliability of success in a formal context against out-of-class immersion through the students' self-perceived autonomy and their formality preferences to see whether it may provide a more appropriate scaffolding toward fluency and proficiency in English (Gholami, 2016). 
The table below shows the analysis of questionnaire items grouped into four categories, as well as their aggregate results. It is interesting to note how, albeit slightly, findings differ when we compare the students' answers on autonomy and those on dependence. Both mean and median (average) values are higher in the autonomy group, which means that the respondents' perception of their behaviour tends towards independence, not dependence. In other words, they see themselves more positively as autonomous learners. The same tendency is evident from the minimum and maximum values, which means that more students recognize themselves as autonomous than they do as dependent. More positive answers on the response scale (Likert-type attitude scale) in all sets of questions correspond to higher autonomy, as well as higher perception of dependence, and vice versa.

Table 1: Self-perception of autonomy and (in)dependence

\begin{tabular}{|l|c|c|c|c|c|c|}
\hline & $\begin{array}{l}\text { Autonomy } \\
- \text { leisure }\end{array}$ & $\begin{array}{l}\text { Autonomy } \\
- \text { study } \\
\text { plan }\end{array}$ & $\begin{array}{l}\text { Autonomy } \\
- \text { total }\end{array}$ & $\begin{array}{l}\text { Dependen } \\
\text { ce- } \\
\text { curricular }\end{array}$ & $\begin{array}{l}\text { Dependen } \\
\text { ce- } \\
\text { extracurric } \\
\text { ular }\end{array}$ & $\begin{array}{l}\text { Dependen } \\
\text { ce-total }\end{array}$ \\
\hline $\mathrm{N}$ & 51 & 51 & 51 & 50 & 50 & 49 \\
Valid & 0 & 0 & 0 & 1 & 1 & 2 \\
Missing & 17.05 & 29.54 & 46.60 & 22.76 & 13.76 & 36.55 \\
\hline Mean & 3.41 & 3.69 & 3.58 & 2.84 & 3.44 & 3.04 \\
Average & 17.00 & 29.00 & 46.00 & 23.00 & 14.00 & 38.00 \\
\hline Median & 4 & 4 & 4 & 3 & 3.5 & 3 \\
Average & 11.00 & 17.00 & 31.00 & 10.00 & 7.00 & 23.00 \\
\hline Min. & 2.2 & 2.12 & 2.38 & 1.25 & 1.75 & 1.91 \\
Average & 22.00 & 38.00 & 58.00 & 31.00 & 18.00 & 46.00 \\
\hline Max. & 4.4 & 4.75 & 4.46 & 3.87 & 4.5 & 3.83 \\
Average & \multicolumn{7}{|r}{}
\end{tabular}

When it comes to individual questions, the situation is practically the same. Table 2 singles out five questionnaire items with the highest scores, or highest agreement with the statements concerning both autonomy and dependence. Four of the five statements in questions pertain to autonomy, while only one examines dependent behavior (Q3: I watch movies/TV series/TV shows in English; Q10: I make an effort to put newly acquired vocabulary into practice; Q12: I am aware that I need to practice English on my own in order to achieve the level of proficiency I desire; Q13: When I practice my English outside classroom requirements I notice my language skills are improving; and 
Q26: When I prepare for the exam, I rely on my own learning strategies). It is important to note here that the one statement on teacher dependence is intentionally formulated positively toward learning autonomy, not dependence. This is done simply to introduce variety in the questionnaire and thus make it less predictable. In sum, all of the questionnaire items with highest agreement scores relate to the students' independence in learning. The respondents who participated in the study predominantly perceive themselves as self-reliant.

Table 2: Self-perception of autonomy and (in)dependence - individual questions

\begin{tabular}{|c|c|c|c|c|c|}
\hline & Q3 & Q10 & Q12 & Q13 & Q26 \\
\hline N & 51 & 51 & 51 & 51 & 51 \\
\hline Mean & 4.20 & 3.98 & 4.45 & 4.41 & 4.35 \\
\hline Median & 5.00 & 4.00 & 5.00 & 5.00 & 5.00 \\
\hline Min. & 1 & 2 & 2 & 3 & 2 \\
\hline Max. & 5 & 5 & 5 & 5 & 5 \\
\hline
\end{tabular}

The findings shown in Table 3 also identify four items in which a consequential majority of respondents declare themselves in full (or almost full) agreement with the statement (Q3: I watch movies/TV series/TV shows in English; Q5: When travelling abroad, I choose to take every opportunity to practice English; Q12: I am aware that I need to practice English on my own in order to achieve the level of proficiency I desire; and Q13: When I practice my English outside classroom requirements I notice my language skills are improving). Their frequencies show that a consequential majority of respondents declare themselves in highest agreement with statements corresponding again to autonomy, not dependence in learning.

Table 3: Self-perception of autonomy and (in)dependence - frequencies

\begin{tabular}{|l|c|c|c|c|}
\hline & Q3 & Q5 & Q12 & Q13 \\
\hline 1 never/untrue & 2 & 1 & - & - \\
\hline 2 & 4 & 2 & 4 & - \\
\hline 3 & 7 & 4 & 2 & 5 \\
\hline 4 & 7 & 8 & 12 & 20 \\
\hline 5 very often/true & 31 & 36 & 33 & 26 \\
\hline
\end{tabular}




\subsection{Research question 1: Autonomy in learning and academic success}

Once it was established that the participants of the study perceived themselves positively as autonomous learners, the next logical step was to look for potential correlations between explicitly autonomous behaviour and academic achievement. The analysis, presented in Table 4, has yielded only a few significant correlations, most notably the one between final grades in all four obligatory English courses and regular communication with foreigners via e-mails, social networks and gaming platforms (question 14). This constant indicates that selfdirected activity leads toward greater competence. Also, regular written communication with foreigners in the target language prepares the students for the written assignments required in the classroom, as well as in final written examinations. The second discovery was the (rather logical) correlation between reading newspapers in English (question 2) and performing more successfully in final examination, albeit only in two of the four obligatory English courses. Informing themselves on current world affairs by reading relevant newspapers and magazines helps the students to acquire new vocabulary, as well as the written academic style necessary for adequate communication in their professional fields. This leads us to conclude that it is written communication, as well as reading habits, that might affect the students' success in final examinations.

However, statistical analysis has shown a correlation shortage: students who are more autonomous in extracurricular settings - both in leisure and as conscious effort - are not significantly more successful academically than less autonomous students.

Table 4: Correlations between autonomy in learning and academic success (individual questions)

\begin{tabular}{|c|l|l|l|l|}
\cline { 2 - 5 } \multicolumn{1}{c|}{} & $\begin{array}{l}\text { English } \\
\text { Language 1 }\end{array}$ & $\begin{array}{l}\text { English } \\
\text { Language 2 }\end{array}$ & $\begin{array}{l}\text { English } \\
\text { Language 3 }\end{array}$ & $\begin{array}{l}\text { English } \\
\text { Language 4 }\end{array}$ \\
\hline $\begin{array}{c}\text { Autonomy } \\
\text { Q2 }\end{array}$ & & $.348^{*}$ & $.321^{*}$ \\
\hline $\begin{array}{c}\text { Autonomy } \\
\text { Q14 }\end{array}$ & $.290^{*}$ & $.349 *$ & $.388^{* *}$ & $.354^{*}$ \\
\hline
\end{tabular}

* Correlation is significant at the 0.05 level

** Correlation is significant at the 0.01 level 
Estimating that autonomous learning overall might have a more meaningful influence on one's academic success than the individual correlations suggest, aggregate results were further analysed. As displayed in Table 5, the analysis revealed a different reality - only one significant correlation, and a negative one at that, between autonomous learning as leisurely activity and academic success in the course English Language 2. This peculiar finding begs a peculiar question: Is there an impeding factor to achieving good grades if the students approach learning English autonomously? One feasible explanation is that such students, who are presumably all the more confident in their language skills and performance, prepare less attentively and less studiously for their exams, especially if they were successful in English Language 1. This somewhat hasty conclusion necessitates further debate and additional study, which could be the subject of another paper.

Table 5: Correlations between autonomy in learning and academic success (group results)

\begin{tabular}{|l|l|l|}
\hline & $\begin{array}{l}\text { Autonomy - } \\
\text { leisure }\end{array}$ & $\begin{array}{l}\text { Autonomy - } \\
\text { study plan }\end{array}$ \\
\hline $\begin{array}{l}\text { English } \\
\text { Language 1 }\end{array}$ & & \\
\hline $\begin{array}{l}\text { English } \\
\text { Language 2 }\end{array}$ & $-.352^{*}$ & \\
\hline $\begin{array}{l}\text { English } \\
\text { Language 3 }\end{array}$ & & \\
\hline $\begin{array}{l}\text { English } \\
\text { Language 4 }\end{array}$ & & \\
\hline $\begin{array}{l}\text { Average } \\
\text { grade }\end{array}$ & \\
* Correlation is significant at the 0.05 level \\
** Correlation is significant at the 0.01 level
\end{tabular}

Another plausible explanation that could be offered for such unexpected findings is graphically presented in Figure 1: most participants of the study were very good or excellent students in all four English language courses. This unrealistic homogeneity, or academic uniformity, might have blurred any significant indicators that could have implied a connection between autonomy in learning and academic success, as was validly expected. The considerable disproportion of the students' final grades, tending toward the highest grades - very good (4) and excellent (5), created a statistically insignificant moment, in which the low 
dispersion of numerical values (grades) disallows potential stronger correlations, so the results themselves do not differ consequentially in any set of questions.

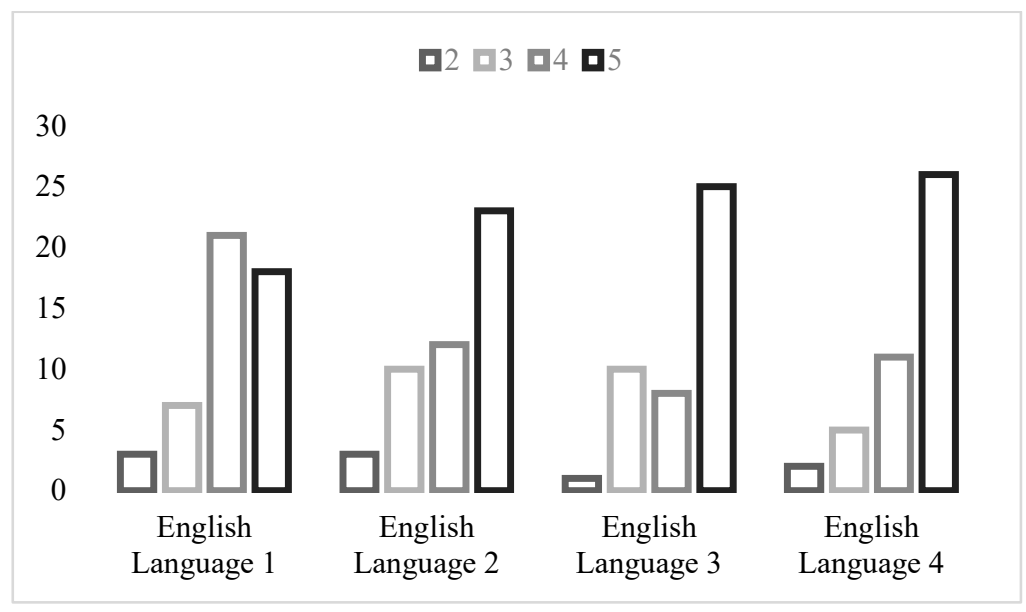

Figure 1: Frequencies of final grades

The results compiled in Table 6, showing the distribution of final grades in all four obligatory foreign language courses at the undergraduate level, are presented separately. Both the mean and median values, which are considerably high, signify a certain disproportion of the students' responses, namely that a substantial majority of them achieved very good or excellent grades in final examinations. Due to this low dispersion, inopportunely, the students' answers depicting learning behaviour, in correlation to their final grades, or numeric academic success, cannot give a most realistic account of the assumed interaction. This, in turn, means, that the statistical findings are not as significant as the author had hoped. 
Table 6: Final grades - average results

\begin{tabular}{|l|c|c|c|c|c|}
\hline & $\begin{array}{l}\text { English } \\
\text { Language } \\
1\end{array}$ & $\begin{array}{l}\text { English } \\
\text { Language } \\
2\end{array}$ & $\begin{array}{l}\text { English } \\
\text { Language } \\
3\end{array}$ & $\begin{array}{l}\text { English } \\
\text { Language } \\
4\end{array}$ & $\begin{array}{l}\text { Average } \\
\text { grades }\end{array}$ \\
\hline N & 49 & 48 & 44 & 44 & 42 \\
Valid & 2 & 3 & 7 & 7 & 9 \\
Missing & 2.10 & 4.15 & 4.30 & 4.39 & 4.22 \\
\hline Mean & 4.00 & 4.00 & 5.00 & 5.00 & 4.5 \\
\hline Median & .872 & .967 & .904 & .868 & .835 \\
\hline $\begin{array}{l}\text { Std. } \\
\text { Deviation }\end{array}$ & 2 & 2 & 2 & 2 & 2 \\
\hline Min. & 5 & 5 & 5 & 5 & 5 \\
\hline Max. & & & & & \\
\hline
\end{tabular}

\subsection{Research question 2: Teacher-dependence and academic success}

Optimistically searching for more significant answers to the second research question, if there are significant correlations to be found between teacherdependence and academic success, the author has expected that a moderate dependency upon the teacher in the form of support, leadership and guidance might have had an impact on the students' academic achievement. But, no significant correlations were found, as Table 7 demonstrates. The analysis of the students' individual answers points to a tendency to have lower grades as a result of teacher-dependent behaviour. There are negative correlations between final grades and the following statements: waiting for the teacher's instructions for classroom assignments (question 15), out-of-class engagement coming down to homework set by the teacher (question 19) and employing strategies used in class in exam preparation (question 25). Again, such results could be assigned to the respondents' comparability or closeness in terms of their final grades, however, the findings imply that the more independent the students are, the better grades they will have, as would have been logical to assume in the first place if everyday classroom experiences had not exposed a different reality.

Also, the analysis of group results showed no significant correlations in the students' answers that might point to a tendency to have better grades as a result of teacher-dependent behavior. Again, this unexpected interval is probably to be explained in terms of respondents' academic uniformity - the majority of participants were students with very good or excellent grades. 
Table 7: Correlations between teacher dependence and academic success (individual)

\begin{tabular}{|l|l|l|l|l|}
\hline & $\begin{array}{l}\text { English } \\
\text { Language 1 }\end{array}$ & $\begin{array}{l}\text { English } \\
\text { Language 2 }\end{array}$ & $\begin{array}{l}\text { English } \\
\text { Language 3 }\end{array}$ & $\begin{array}{l}\text { English } \\
\text { Language 4 }\end{array}$ \\
\hline $\begin{array}{l}\text { Dependence } \\
\text { Q15 }\end{array}$ & $-.420^{* *}$ & & & \\
\hline $\begin{array}{l}\text { Dependence } \\
\text { Q19 }\end{array}$ & & & & $-.301^{*}$ \\
\hline $\begin{array}{l}\text { Dependence } \\
\text { Q25 }\end{array}$ & & & & $-.317^{*}$ \\
\hline
\end{tabular}

* Correlation is significant at the 0.05 level

** Correlation is significant at the 0.01 level

\subsection{Research question 3: Correlating autonomy in learning and teacher-dependence}

This question has arisen as a sheer impression, as an inkling the author has had teaching English to student of diplomacy. Since a considerable number of excellent students exhibited, somewhat unexpectedly, a dependence on the teacher and the formal, structured context for learning (clear instructions on activities, providing correct answers, etc.), and were rather autonomous in their extracurricular activity, there has emerged a suspicion that there might be a connection between such different behaviours. Both the initial analysis of individual questions and the post hoc analysis of regrouped questions generated no significant correlations. This again may well be the result of participants' academic homogeneity, but still, numbers have shown no significant correspondence between autonomous and dependent behaviour, not even in this particular narrow context.

The data presented in Table 8 shows that it is only questions 1 and 10 from the autonomy group - reading books in English for personal pleasure/leisure and making an effort to put newly acquired vocabulary into practice - that interact with three or more statements from the dependence group: communicating with colleagues in English in pair/group work (question 20); taking the teacher's advice to watch movies and read books and newspapers in English (question 21), to practice writing resumes and personal statements (question 23), as well as to look up and use new vocabulary (question 22). All correlations found after the analysis point to the fact that students tend to express considerably higher agreement with statement which communicate autonomy. Statements which 
require agreement with straightforwardly dependent behaviour (such as waiting for the teacher's instructions or correct answers) have established no correlations with statements on autonomy. It is only logical to conclude that autonomous behaviour does not correlate to teacher-dependence. However, as implied before, the reality in the classroom is somewhat different. This can be explained by the fact that the students' perception of their own behaviour is different than the teacher's, or by the fact that dependent behaviour is recognized as undesirable, so the respondents, at least some of them, deliberately avoided to provide honest answers. Thirdly, it might have been the case, even though statistically improbably, that none of the students who exhibited such behaviour in the classroom participated in the study. Be that as it may, the statistical analysis has yielded no significant results to corroborate the initial hypothesis: that autonomous learners might as well be dependent in certain classroom situations. 
Table 8: Correlations between autonomy and dependence (individual)

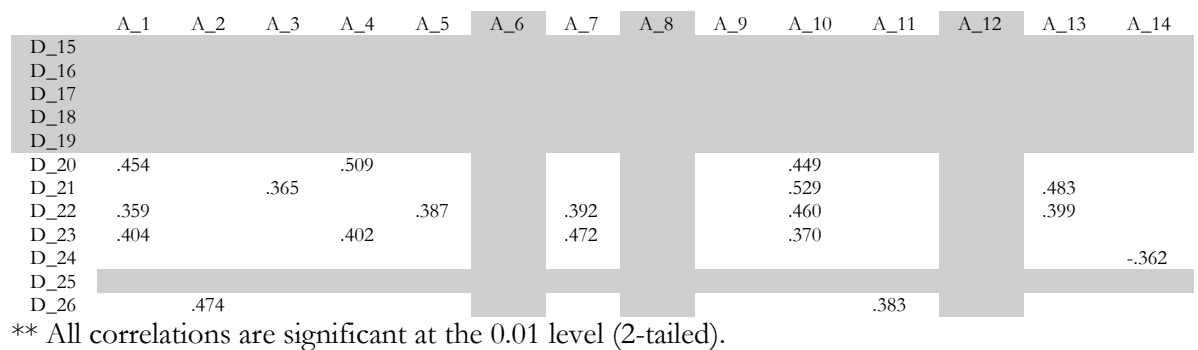

Aggregate results presented in Table 9 show that dependent behaviour in the classroom does not correlate to autonomy in learning. For example, if a student is an autonomous learner, both in the form of a structured study plan and as pastime, they are more likely to be independent in the classroom. The anticipated autonomy-dependence relationship often seen in the students' behaviour in the classroom is once again left unsubstantiated.

Table 9: Correlations between autonomy and dependence (aggregate)

Autonomy -

$\begin{array}{llll}\text { Autonomy } & \text { Autonomy } & \text { Dependence } & \text { Dependence - } \\ \text { - leisure } & \text { - study } & \text { - curricular } & \text { extracurricular } \\ & \text { plan } & & \end{array}$

leisure

.552

Autonomy -

study plan

Dependence curricular

Dependence extracurricular

** All correlations are significant at the 0.01 level (2-tailed).

\section{$4 \quad$ Discussion and further steps}

The aim of this paper was to analyse the questionnaire distributed to first- and second-year students of the undergraduate study of international relations and diplomacy at the Dag Hammarskjöld University College, in which they were asked to evaluate their attitudes toward and their perception of autonomy and dependence in learning English. The primary objective was to search for relevant interactions between their learning behaviours - autonomous and/or dependent 
- and their final academic success, expressed in numeric grades. The hypotheses considered the following: that there would be significant correlations between autonomy, dependence and final grades, as well as that there might be a connection between autonomy in learning beyond the classroom and dependent behaviour in the classroom, and a positive one at that. The analysis, on the other hand, has yielded very different results. Not only were there no significant correlations found between independent learning outside the language classroom and the students' preference of formal, teacher-centred contexts, which was to be expected, but there was also very little reciprocity between learning behaviour and final academic success. The reason for that, in all probability, lies in the nature of the analysis itself. The questionnaire results were examined quantitatively, using statistical techniques to analyse the data, namely correlations of the three variables - the students' perceptions of autonomy and teacherdependence, as well as their final grades. This method might have given more significant results if there was a larger number of respondents, and if the respondents were more diversified when it came to their final grades. As seen in the analysis, a considerable number of participants were very good or excellent students, a fact that could have obscured any potential meaningful findings. As for the third hypothesis, whether there could be a consequential relation between learner autonomy out-of-class and an expressed dependence upon the teacher in a formal academic context, a different methodology would probably have yielded more revealing results. In a further study, the author might attempt to conduct interviews with those students whose behaviour in the classroom stimulated the interested in this somewhat unusual topic. Interviews could provide a more fitting methodology to research this phenomenon, since it is quite a specific profile of students/learners we are inclined to survey. This phenomenon - being autonomous and dependent - is much more incidental than the author initially suspected, and it seems to occur in relatively unpredictable conjunctions with circumstances such as reading books and watching movies in the target language or waiting for the teacher to provide correct answers before writing them down. That is why the approach used to investigate it needs to be qualitative in nature, and much more personalized and nuanced than an online survey. 


\section{$5 \quad$ Conclusion}

This paper was an attempt to contextualize the three very important elements of foreign language learning - the notions of learner autonomy, teacher-dependence and academic success - both inside the language classroom and beyond, and to examine the possible interactions between the factors constituting the students' academic achievement. Such a research inquiry was then used to try to justify a "hunch" the author has had in her experience as English language teacher at a university college in Zagreb - that autonomy in language learning and dependence upon the teacher and a formal context for learning do not necessarily rule each other out. A considerable number of students the author has taught over the years had language learning histories decidedly lacking in classroom instruction, yet they were highly proficient and, what is more, efficiently autonomous. On the other hand, a large number of such students exhibited indicatively teacher-dependent behaviour when it came to course assignments and requirements. An explanation that arose logically was that such peculiar behaviour was connected to their inexperience in academic learning, resulting in a certain insecurity and over-reliance upon the teacher's instructions, leadership, approval. This assumption was then put to the test - a statistical analysis of the said variables in order to find significant correlations between learner autonomy, teacher dependence and the student's final grades. Unfortunately, the hypotheses put forward in this paper were only weakly supported by the final test results very few significant correlations were found to corroborate the theory. It is reasonable to presume that the reason for this surprising deficiency was an illfitted methodology used in the research: instead of employing a questionnaire and examining it quantitatively, the theory should have been tested and assessed qualitatively, conducting interviews with students whose behaviour had been suspected as peculiarly autonomous and dependent at the same time. As for the other two hypotheses, connecting autonomy in learning and teacher dependence to academic success, respectively, the impeding factors were, suspectedly, the relatively small number of participants, as well as uneven distribution of their final grades, which created a deceivably slight variation of responses concerning numerical success. This, in turn, generated unrealistic homogeneity in the representation of the students' behaviour, which resulted in unimpressive statistical data. To remedy the overall situation, the questionnaire ought to be reused on a larger sample, while the final question should be tested individually, as it is a subtle particularity, an idiosyncrasy, not a trait that can be detected via an online survey. All things considered, this is too important a subject to be 
dismissed due to a few glitches in the testing machinery; it is indispensable for the teachers to understand how their students learn and how they can profit the most from academic courses we teach.

\section{References}

Benson, P. (2011). Language learning and teaching beyond the classroom. In P. Benson \& H. Reinders (Eds.), Beyond the language classroom (pp. 7-16). Basingstoke, UK: Palgrave Macmillan.

Benson, P. (2008). Teachers' and learners' perspectives on autonomy. In T. Lamb \& H. Reinders (Eds.), Learner and teacher autonomy: Concepts, realities and responses (pp. 1532). Amsterdam/Philadelphia: John Benjamins Publishing Company.

Gholami, H. (2016). Self-assessment and learner autonomy. Theory and Practice in Language Studies, 6(1), 46-51.

Little, D. (1991). Learner autonomy 1: Definitions, issues and problems. Dublin: Authentic Language Learning Resources.

Macaro, E. (2008). The shifting dimensions of language learner autonomy. In T. Lamb \& H. Reinders (Eds.), Learner and teacher autonomy: Concepts, realities and responses (pp. 47- 62). Amsterdam/Philadelphia: John Benjamins Publishing Company.

Oxford, R. L. (1990). Language learning strategies: What every teacher should know. Boston, Massachusetts: Heinle \& Heinle Publishers.

Oxford, R. L. (2003). Toward a more systematic model of L2 learner autonomy. In D. Palfreyman \& R. C. Smith (Eds.), Learner autonomy across cultures (pp. 75-91). Basingstoke, Hampshire; New York, NY: Palgrave Macmillan.

Palfreyman, D. (2003). The representation of learner autonomy and learner independence in organizational culture. In D. Palfreyman \& R. C. Smith (Eds.), Learner autonomy across cultures (pp. 183-200). Basingstoke, Hampshire; New York, NY: Palgrave Macmillan.

Palfreyman, D. M. (2011). Family, friends and learning beyond the classroom: Social networks and social capital in language learning. In P. Benson \& H. Reinders (Eds.), Beyond the language classroom (pp. 17-34). Basingstoke, UK: Palgrave Macmillan.

Trebbi, T. (2008). Freedom-a prerequisite for learner autonomy? Classroom innovation and language teacher education. In T. Lamb \& H. Reinders (Eds.), Learner and teacher autonomy: Concepts, realities and responses (pp. 33-46). Amsterdam/Philadelphia: John Benjamins Publishing Company. 


\section{Appendix}

\section{QUESTIONNAIRE ON LEARNER AUTONOMY AND TEACHER- DEPENDENCE}

1. I read books in English for personal pleasure/leisure.

Never---1---2---3---4---5---Very often

2. I read newspapers in English to inform myself on world affairs.

Never---1---2---3---4---5---Very often

3. I watch movies/TV series/TV shows in English (without subtitles in my mother tongue).

Never---1---2---3---4---5---Very often

4. When reading for classes in Croatian, I choose literature in original language (English) even where there are translations available.

Never---1---2---3----4---5---Very often

5. When travelling abroad, I choose to take every opportunity to practice English.

Never---1---2---3----4---5---Very often

6. I download and use dictionary and language tool apps on my smartphone.

Never---1---2---3---4---5---Very often

7. I have a study plan to improve my English (e.g. watching one movie per week, reading one book per month, initiating communication in English with my colleagues on a daily basis, etc.).

Very untrue of me---1---2---3---4---5---Very true of me

8. My learning happens spontaneously - i.e. I notice my progress in language only after it has happened.

Very untrue of me---1---2---3---4---5---Very true of me

9. I consciously work on overcoming language anxiety and shyness by taking every opportunity I have to practice my speaking skills.

Very untrue of me---1---2---3---4---5---Very true of me

10. I make an effort to put newly acquired vocabulary into practice.

Very untrue of me---1---2---3---4---5---Very true of me

11. I feel confident I can improve my English relying on my own study plan (e.g. watching movies, reading books, speaking English with my colleagues, etc.). Very untrue of me---1---2---3---4---5---Very true of me

12. I am aware that I need to practice English on my own in order to achieve the level of proficiency I desire.

Not at all aware---1---2---3---4---5---Extremely aware 
13. When I practice my English outside classroom requirements (movies, books, communication with peers) I notice my language skills are improving.

Never true---1---2---3---4---5---Always true

14. How often do you communicate with foreigners in English on social networks, gaming platforms or via e-mails?

Less than once a month---1---2---3---4---5---On a daily basis

15. In class, I wait for the teacher's instructions for classroom assignments and exercises even though there are written instructions available beforehand. Very untrue of me---1---2---3---4---5---Very true of me

16. I wait for the teacher to provide or confirm correct answers before I write them down.

Very untrue of me---1---2---3---4---5---Very true of me

17. I ask the teacher rather than my colleagues for further instructions or additional clarification before setting on a task.

Very untrue of me---1---2---3---4---5---Very true of me

18. I ask the teacher for suggestions for presentation topics and literature.

Never---1---2---3---4---5---Very often

19. My out-of-class language engagement comes down to homework set by the teacher.

Very untrue of me---1---2---3---4---5---Very true of me

20. When preparing for a task in pair or group work, I choose to communicate with my colleagues in English rather than in Croatian.

Very untrue of me---1---2---3---4---5---Very true of me

21. I take the teacher's advice to practice my English out of class by watching movies and reading books and newspapers in English, and by speaking to my international colleagues.

Not a priority---1---2---3---4---5---High priority

22. I take the teacher's advice to practice my English out of class by looking up new vocabulary and trying to use it immediately.

Not a priority---1---2---3---4---5---High priority

23. I take the teacher's advice to improve my English out of class by writing practice personal statements, resumes and letters of intent to pretend (or real) future employers.

Not a priority---1---2---3---4---5---High priority

24. My out-of-class reading activity comes down to reading about popular culture rather than current world affairs

Very untrue of me---1---2---3---4---5---Very true of me 
25. When I study for the exam, I employ the strategies we use in class (synonym matching, definitions, etc.)

Very untrue of me---1---2---3---4---5---Very true of me

26. When I prepare for the exam, I rely on my own learning strategies.

Very untrue of me---1---2---3---4---5---Very true of me

27. Please enter your final grades in English Language 1, 2, 3 and 4 at the Dag Hammarskjöld University College of International Relations and Diplomacy in Zagreb. 


\title{
Quest Technologies in Teaching Foreign Languages
}

\author{
YULIYA LUKINYKH
}

\begin{abstract}
Tendency to use quest technologies in teaching humanitarian disciplines, in particular, in teaching foreign languages, is due to the fact that they develop critical thinking, ability to compare, analyze, and classify information. This is an interactive form that allows teachers to involve all the students, to realize their creative abilities, to embody their available knowledge and skills in practical activities. Educational quest is a pedagogical technology which includes a set of problem tasks with role-playing elements; their performance requires any resources, first and foremost, the resources of Internet. A special feature of web quests is that some information or the whole one presented on the website for self-study or group work is actually on different websites. Thanks to the existing hyperlinks, students do not feel it, but work in a single information space. Quest technologies have a number of similarities with computer games, on the basis of which they are built, in fact. Firstly, it is achievement of the ultimate goal through the search for intermediate solutions. Secondly, it is a system of tips. The article discusses the concept of quests, their types and structure; as well as the advantages and disadvantages of using quest technologies in foreign language lessons.
\end{abstract}

Keywords: - foreign languages - interactive teaching methods $\bullet$ quest $\bullet$ quest-technologies $\bullet$ educational process $\bullet$

CORRESPONDENCE ADDRESS: Yuliya Lukinykh, Candidate of Pedagogics, Associate Professor, St. Petersburg University of Management Technologies and Economics, Institute of Economics, Krasnoyarsk, Lermontovskiy Prospekt 44A, 190103 Sankt-Peterburg, Russia, e-mail: yulla@bk.ru. 


\section{$1 \quad$ Introduction}

As a concept, quest technology appeared in the educational process quite recently. In 1995, professor Bernie Dodge of the University of San Diego and his student Tom March, an English teacher, developed a model of web quest as one of the strategies for the successful integration of the Internet into the educational process. Initially, this technology was designed to interest the students, creating a process similar to the game. These are games (either on computer or in real life) that became a starting point of such direction in pedagogic and teaching methods (Goncharova, 2007).

Quests can be used at different levels of learning in the educational process. They can cover a single topic, the entire subject, and can be inter-representative. The advantage of quest lessons is the use of active learning methods. They can be designed for both group and individual work.

Tendency to use quest in teaching humanitarian disciplines, in particular, in teaching foreign languages, is due to the fact that they develop critical thinking, ability to compare, analyze, and classify information. Students become more motivated as they perceive the task as "real" and "useful", which leads to a more effective cognitive process.

As a game form of learning, quest also contributes to the development of imagination, interrelation of emotional contacts between students, relieves excessive psychological stress, helping to experience a sense of security, mutual understanding and their own success (Osyak et al., 2015).

The relevance of the topic is determined by the necessity of using quest technology in the classroom, as today`s students are knowledgeable in the most recent "gadgets". The task of the teacher is to involve them in the educational process, in creative activities and to enable realization of their abilities. Therefore, the interactive forms which allow involving all the participants, realizing their creative abilities, applying their available knowledge and skills in practical activity become the most demanded nowadays. 


\section{Quest technology concept}

\subsection{Notion}

The English word 'quest' means "search, search objects, adventure search". In mythology and literature the term "quest" originally meant one of the ways of constructing the plot - the journey of the characters to a certain goal by overcoming obstacles and difficulties (Chernysh, 2016, p. 45).

As mentioned above, for the first time the term "quest" as an educational technology was proposed by B. Dodge. The scientist developed innovative Internet applications for integration into the educational process in teaching of various subjects at different levels of education. The name "quest" was given to a site that contained a problematic task and involved an independent search of information on the Internet (Goncharova, 2007).

Until a certain time quests and pedagogy existed in parallel and weren `t linked. The revolution in this issue was due to computer technologies. Quest technology came in pedagogy from the world of computer games in the late XX century. In the 90s, computer company "Sierra" released a series of games like "King's Quest”, “Space Quest”, "Police Quest”, etc., which caught the players` fancy.

It all started with quests where the main character had to solve a certain problem, for example, to neutralize a dragon. To achieve this (or any other) goal, he had to perform a number of secondary tasks (say, find a sword or get a sleeping pill to put down a dragon), and the implementation of these tasks was in turn associated with a number of following actions, etc.

Also unprecedented entertainment facilities began to appear around the world, where customers were asked to try to get out of the locked room, solving a lot of difficult tasks or escape from certain paranormal phenomena. Thus, the quests began to win the hearts of the people (Osyak et al., 2015).

Educational quest is a pedagogical technology which includes a set of problem tasks with role-playing elements; their performance requires any resources, first and foremost, the resources of Internet. Quests can be used to work with students, parents or colleagues. 


\subsection{Classification}

Educational quests are classified into the following types:

- sequential quests, where a step-by-step puzzle is offered, guessing which members receive a hint to go through the next stages;

- quests-projects that allow students to organize research activities in the form of a game;

- quests-action games where you need to not only pass the next stage, but also to collect tips that may be useful for the tasks.

The basic model of the quest is a process cycle. At this stage of the quest design, in addition to selecting a theme and forming a problem, it is necessary to develop a storyline from the "journey" series. As well as determination of the route stages, selection of tasks with a single goal, and also a system of hints (assistants) (Kalugina \& Mustafina, 2015).

In general classification one distinguishes the following types of quests:

- linear (the solution of one problem makes it possible to solve the following one);

- attack (using the check prompts a participant chooses a way of solving the problem);

- $\quad$ ring (essentially the same linear quest for teams starting from different points) (Osyak et al., 2015).

One can select a web quest separately. Web quest in pedagogy is a problem task with the elements of role-playing game, which uses information resources of the Internet. It is the most difficult for both students and a teacher. The web quest is aimed at developing the skills of analytical and creative thinking; a teacher who creates the web quest must have a high level of subject, methodological and infocommunication competence.

A special feature of web quests is that some information or the whole one presented on the website for self-study or group work is actually on different websites. Thanks to the existing hyperlinks, students do not feel it, but work in a 
single information space, for which it is not an essential factor the exact location of a portion of educational information.

A student is given a task to collect materials on the Internet on a particular topic, to solve any problem using these materials. References to some sources are given by the teacher, and some they can find themselves using conventional search systems. At the end of the quest, students either present their own web pages on the topic, or some other creative work in electronic, print or oral form (Shevtsova, 2008).

Quest technologies have a number of similarities with computer games, on the basis of which they are built, in fact. Firstly, it is the achievement of the ultimate goal through the search for intermediate solutions. Secondly, it is a system of tips (however, they are not always found, which complicates a search for the right solution).

\section{$2.3 \quad$ Structure}

The structure of the quest technology is as follows:

- problem statement (introduction) and distribution of roles;

- list of tasks (stages, list of questions, etc.);

- order of execution of the tasks (fines, bonuses);

- ultimate goal (prize) (Kalugina \& Mustafina, 2015).

Bernie Dodge highlighted a clear structure of the web-quest: Introduction; Task; Process; Evaluation; Conclusion; Materials; Teacher Page.

Let`s consider the stages in details.

1) Introduction - formulation of a topic, description of the participants ' main roles, quest script, work plan or overview of the entire quest. The goal is to prepare and motivate students. Therefore, motivational and cognitive values are important here. 
2) Task - a clear and interesting description of the problem and a form of presentation of the final result:

- problem or mystery that needs to be solved;

- position you need to formulate and defend;

- product that you want to create;

- abstract, which must be created;

- report or journalistic report;

- creative work, presentation, poster, etc.

The task should be problematic, clearly formulated, have a cognitive value.

3) Process - an accurate description of the main stages of work; a guide to action, useful tips for collecting information (a checklist of questions for the analysis of information, a variety of tips for the implementation of a task, "blank" Webpages for reports, recommendations for using information resources, etc.). From a methodological point of view, the material should be relevant, diverse and original in resources; have a variety of tasks with a focus on the development of high-level mental skills; availability of methodological support - auxiliary and additional materials to perform tasks; when using elements of role-playing - there should be an adequate choice of roles and resources for each role.

Here you can specify links to resources and do not allocate a separate section for them.

4) Evaluation - description of the criteria and parameters for evaluating the webquest, which is presented as an evaluation form. Evaluation criteria depend on the type of training tasks that are solved in the web-quest. Adequacy of the evaluation criteria presented to the type of task, clarity of the evaluation criteria and parameters description, ability to measure the results of the work are subjected to methodological assessment.

5) Conclusion - a brief and accurate description of what students can learn by completing this web-quest. There should be a relationship with the introduction. 
6) Materials: links to the resources used to create the web-quest. This section can be combined with the Process section.

7) Teacher page - methodical recommendations for teachers who will use a webquest (Osyak et al., 2015).

It should be mentioned, that this structure is not something that is frozen and is used only as a basis, which can be changed if necessary. A teacher can design a quest according to the level and needs of his students.

\section{Advantages and disadvantages of using quests}

It goes without saying that the role of quest-technologies in the modern world cannot be underestimated. According to many teachers who successfully implement web quests in the educational process, this technology provides three main components of productive language training: problematicity, authenticity and interactivity, which is a leading factor in learning a foreign language. Web quests allow students to receive information orally and in writing (reading web pages or participating in discussions in the language of study). In interactivity, knowledge of the language is immediately tested, at the same time enriching with new content. All this contributes to the development of fluency, accuracy in the use of language and at the same time enriching the vocabulary (Zhebrovskaya, 2013).

Carrying out project work with the help of network resources has a number of certain advantages:

- web quests give the teacher a sample of how to carry out project work;

- you can find a lot of interesting developments on Internet. You can start by selecting the finished product and use it without changes (or maybe slightly changing);

- there are templates on the Internet that can be very useful for teachers who want to create their own web quests, various tasks that are suitable to the proposed technology, a lot of methodological tips for teachers on how and where to find useful sites when creating a web quest, as well as a list of search engines and instructions for their use; 
- a teacher provides a list of sites that students use to complete the project. As a result, they spend less time searching for the necessary information than on the task;

- many students will be happy to work on this technology to improve their language skills.

But, however, there are difficulties and problems in using web quests:

- to complete a project, students must have access to the Internet;

- web quest technology requires children and adults to have a certain level of computer literacy;

- slow Internet may limit the type of downloaded resources (e.g. video);

- a lot of web quests that can be found on the Internet are created abroad, so they need to be adapted to specific learning conditions (Shevtsova, 2008).

Quest is a completely new form of both educational and entertainment programs, which allows children to immerse themselves fully in the events. "Live" quest is built on communication interaction between players. It is impossible to achieve individual goals without communication with other players; it stimulates communication and serves as a good way to unite players. "Live" quests carry an element of competition; they contribute to the development of analytical abilities. Immersion in the atmosphere of the game would be incomplete without unexpected meetings, for example, with the mysterious inhabitants of ancient fortresses or abandoned forts. Students can supplement "live" quests in the course of their passage, it all depends on the imagination and ingenuity of the participants (Zhebrovskaya, 2013).

Using quests can help at least partly to get away from the boring class - lesson system of sitting at the desks as well as to expand educational space.

Teachers at secondary schools, colleges and universities are increasingly paying attention to the quest as an innovative technology and learning model. In modern educational practice, it is a model that combines a long-term purposeful search in the performance of a problem task with an adventure or a game. 


\section{$4 \quad$ Experience of using quest technology}

Today, modern education tends to ensure that students master certain competencies. Some teachers use standard methods and generally accepted pedagogical technologies in their work, which also help to master the necessary competencies, while others try to diversify their teaching activities, including in the educational process new teaching methods and educational tools, which are then systematically used in the educational process. One of such methods is a quest-lesson (Osyak et al., 2015).

When developing a lesson with the use of quest technologies, it is important to take into account the age of children and their psychological characteristics. Testing of quest technology took place in the sixth grade of one of the gymnasiums in Krasnoyarsk (Russia).

\subsection{Quest scenario}

The quest is called "Royal holidays". Aim - to improve forms and methods of extracurricular work on learning English by involving pupils in an entertaining interactive action and developing interest in learning English.

Quest objectives :

- to draw attention of the younger generation to the monuments and cultural sites of the United Kingdom;

- to introduce cross-cultural information;

- to develop a sense of involvement in task decision;

- to help in learning new useful information;

- to create conditions for the creative potential of the participants;

- to create conditions for self-realization;

- to encourage students to study further the history and geography of the $\mathrm{UK}$, its cultural and language features, to instill respect for history, cultural and historical monuments.

The "Royal holidays" quest game is a series of tasks that are performed by two teams in succession. Each team goes through all the stations one by one. According to the scenario, the participants are reported that the Royal family went on vacation and invited us with them, but we could get to them only after 
passing some stages. Having divided into the teams of 5 pupils, participants chose the names of teams -"Manchester" and "London Eye" - and captains.

Then the team captains received route sheets with the names of the stations, and all the participants run up to different stations: "Symbolic"; "Lexicology palace"; "Country Puzzle”; “Spy glass”; “Mr. Tongue Twister”; "Big family”.

At six stations the children are waiting for a variety of contests and quizzes, and in the end - a Super-game, during which they will have to guess about the place where the Royal family stopped to rest. Each team must perform a number of tasks for a certain time and achieve the result - to collect maximum possible number of "Royal crowns" and minimum number of "black marks". For correct answers the team gets the "Royal crown", and for the wrong answers the team gets the "black mark". Also, after passing each station, the team is given a piece of the map - the route along which the Royal family was moving. After passing the last station, the participants get a piece of a map with a cross drawn on the place where they have to come to win and get a prize. The passage of each stage makes it possible to move to the next stage.

The place of the quest - classrooms, library, Assembly hall.

Necessary equipment: maps with an individual route; plaques with the station names; props at the stations; tasks for each station; certificates for winners and participants; prizes.

Preparatory work: to prepare tasks for each stage; to make marks and crowns for participants; to determine rooms for the stations; to instruct an assistant; to attach the plates to the doors; to arrange the Assembly hall.

At the end of the quest, the winning team is determined. Team members are awarded with certificates of winners; other teams are awarded with certificates of participants. All participants will receive sweet prizes that they have to discover in the end in the Assembly hall. 
The contents of the quest (for stations):

1) Station "Symbolic" was developed taking into account the fact that the pupils have already studied the symbols and flags of Britain. The essence of the station is that that they see a flag and say what part of the UK it belongs to. Then they have to name the symbols (flowers, animals, patrons) of the guessed pieces.

2) Station "Lexicology palace" - a game on the associations. The participants are given three A4 sheets, with a word in the center: "kingdom", "holiday", "Britain". The task is to write as many words-associations as possible for a certain period of time.

3) At the station "Country puzzle" children must match a picture with a sight of Britain and its title. On the table they have pictures and pieces of paper with the sight names. A certain time is given on this task.

4) At the station "Spyglass" participants are invited to guess six proverbs and sayings in English. If they translate a proverb, they get for each one a "crown", and if they give a Russian equivalent - two "crowns":

\author{
Better late than never. \\ East or West home is best. \\ It is never too late to learn. \\ Learning is the eye of the mind. \\ Lovely weather for ducks! \\ You made your bed, now you have to lie in it.
}

5) At the station "Mr. Tongue Twister" participants need to read tongue twisters as accurately, clearly and quickly as possible. They can get extra "crowns" if they can translate these twisters:

Can you can a can as a canner can can a can?

A big black bug bit the big black bear but the big black bear bit the big black bug back!!

The thirty-three thieves thought that they thrilled the throne throughout Thursday.

$M r$. Tongue Twister tried to train his tongue to twist and turn, and twit an twat, to learn the letter $\langle T\rangle$. 
6) The "Big family" station is the final one where the participants can earn a lot of "crowns" if suddenly they feel that they are far behind. Team members receive envelopes with the images of all members of the Royal family, their titles and names. The task is to restore the family tree.

\subsection{Quest analysis}

Let`s analyze further passing of each quest station.

Station 1 . When studying the theme about UK, the students were introduced to the symbols and flags of the country. It was decided to make this station the first, as it would be easier for the participants to cope with it and join the process of the game. At this stage both teams coped with the task and quickly moved to the next station.

Station 2. By observation it was found out that the pupils like to perform tasks on the associations. In the course of the quest in some word-associations, they made small spelling mistakes (for example, in the names of cities in the writing of associations to the word "Britain'), but these errors were not taken into account, as they are not the main ones at this station.

Station 3. At this station, the pupils correctly compared such famous attractions as "London Eye", "Big Ben", "Buckingham Palace", but hesitated a little in comparison of some buildings like "Windsor Castle", "Westminster", "Edinburgh Castle". We can assume that this happened due to the fact that all the buildings and castles were similar for them, but that was a small difficulty.

Station 4. Pupils are informed that the Queen is very fond of different winged expressions, proverbs and sayings, and they are given a task to translate from English into Russian the given proverbs, but it is mentioned that they will get more "crowns" if they give a Russian equivalent. It was interesting to notice that both teams tried to choose the equivalents in the first place, and if they could not cope with the task, then they simply translated. It was at this station when the participants felt the excitement and competitive spirit, they wanted to earn more "crowns" and be the first at the finish line. 
Station 5. For a speech warm-up before the lesson, various tongue twisters are often used. Pupils like this stage of the lesson very much, they always try to read as quickly and clearly as possible. We can say that this station was quite easy, there was no need to think, it was necessary to do what they are used to and what they like. Both teams coped very well with the task, although the tongue twisters were chosen completely different, unfamiliar to them before.

Station 6. The final station of the quest. Initially, there was an idea to hide the images of the members of the Royal family, but the decision was changed, because there was a risk that the participants won 't find some portraits, or lose, then the quest would come to a standstill. Therefore, the teams got the envelopes, but inside everything was mixed up, which caused some difficulties, but the pupils coped with the task. Both teams quickly restored the first part of the family tree, where there were Queen Elizabeth I and II, Prince Charles, Princess Diana, Prince Henry - familiar personality to everyone. But the participants thought longer about making portraits of such Royal personalities as Princess Eugene, Princess Charlotte, Prince Edward. This might be due to the fact that in the course of studying this topic in the classroom, much attention was paid to the "founders" of the Royal family.

The results of the quest can be presented in the form of oral presentation, collage, drawings, portfolio. It all depends on the imagination and creativity of the participants.

\subsection{Evaluation stage and some guidelines}

No quest is complete without reflection and evaluation stage at the end. Evaluation is the most difficult stage. It is necessary to evaluate the result of team work and contribution of a particular participant. Transparency should be ensured at this stage.

In the end, the activities of each participant are assessed from multiple perspectives: evaluation of a teacher; independent result obtained in testing; selfassessment. At this stage, the winners and participants who have fulfilled all the conditions of the quest game, which came first, and also earned a greater number of "crowns" are awarded. 
As for the general guidelines for the quest, the first stage of preparation will always be formulation of the main idea and purpose. You need to imagine the main idea of the whole quest, which can be formulated as a thesis, and can be incorporated into the game intrigue of the quest. The basis of the quest plot can be a literary work, events of the famous film or the simplest plot tie (for example, "get out of the maze").

After description of the idea and purpose, it is important to make an approximate list of the information that students should get by completing the quest tasks. The next stage of preparation is actual creation of a route sheet. The basis of the route sheet is different tasks (and here you need to focus on the already existing idea and purpose, a list of actual information, as well as the overall plot of the quest). If the quest is performed on a large area, you need to create a map of the route. Each task is performed at a specific point. These points must be put on the map, which is distributed to all participants with the tasks. The map can be printed or drawn, the numbers on the maps are marked with the numbers of tasks from the route sheet.

Tasks should show something unusual, interesting, and lead the student from visual observations to the knowledge and ideas. It is good when the tasks are integrated into a single plot, overlap with each other, and in the final all the answers are formed in a clear figure (for example, a map pieced together, a drawn picture, an object found, etc.).

In the process of quest participants comprehend real processes, they live specific situations, get involved in the penetration of phenomena, construction of new processes, objects. From the point of view of information activities, each participant needs skills in search, analysis of information, ability to store, transmit, compare and synthesize new information on the basis of comparison.

The success of the educational quest is influenced by many factors, but if planning and implementation of the quest is successful, then in the end there is an opportunity to realize all the main goals of modern education.

Performing a quest project, a pupil learns to formulate a problem, plan his activities, think critically, solve complex problems, weigh alternative opinions, make informed decisions, take responsibility for their implementation. 
This technology is very popular among modern pupils and is able not only to expand their horizons, but also allows one to actively apply knowledge and skills, and fosters a desire to study in general (Kalugina, Mustafina, 2015).

\section{Conclusion}

Having considered the concept and essence of educational quests, we can say that their use contributes the following:

- organization of educational process on the basis of problem and game training, team interaction, information and communication technologies;

- planning of subject pedagogical interaction between teachers and pupils, which contributes to the formation of pupils' cognitive motivation and universal educational actions;

- encouraging use of electronic gadgets and Internet resources in the educational process;

- clear structuring of the lessons with the elements of quest and the content;

- optimization of teacher's work on preparation for the lesson, both in time and effort;

- preparation of teaching materials with educational quests for classes and extracurricular activities (Chernysh, 2016, p. 47).

The use of quest technologies in teaching foreign languages contributes to development of listening and reading skills in a foreign language; search for solutions to problem situations activates logical and creative thinking, contributing to its comprehensive development.

The use of quest technology in teaching foreign languages gives clearly positive results, but requires some training and experience from a teacher and from pupils. It follows that the use of web-quest technology should not be isolated, as technological complexity makes a task more interesting, but it is impossible without practice (Shevtsova, 2008). 
The identified advantages and disadvantages of the use of quest technologies have led to a conclusion that they create conditions for harmonious development of an individual, ensure successful assimilation of knowledge and skills necessary in future life; and is a tool by which a teacher can form pupils`skills and abilities of a XXI century person.

\section{References}

Chernysh, O. E. (2016). Quest - a fun for a funny break? Pedagogical workshop. All for teachers! 3, 45-48.

Goncharova, N. Yu. (2007). New information technologies in foreign language classes at a nonlanguage university. Retrieved from http://www.acis.vis.ru/8/4/1_5/4.htm

Kalugina, Yu. V., \& Mustafina, A.R. (2015). Educational quest as an interactive form of teacbing foreign language. Retrieved from http://e-koncept.ru/2015/85700.htm

Osyak, S. A., Sultanbekova, S.S., Zakharova, T.V., Yakovleva, E.N., Lobanova, O.B., Plekhanova, \& E. M. (2015). Educational quest as a modern interactive technology. Retrieved from http://www.science-education.ru/ru/article/view?id=20247

Shevtsova, O. G. (2008). Web quest as one of the most effective ways to use the Internet to implement role-playing games in training. Retrieved from http://ito.edu.ru/2008/Moscow/III/2/III-2-7656.html

Zhebrovskaya, O. O. (2013). International webinar "Live" quests in education (new educational technologies)". Retrieved from http://ext.spb.ru/index.php/webinars/220922012013-qq-q-q.html 


\title{
The Word Class Noun in English Business Magazines Online
}

\author{
BORISLAV MARUŠIĆ \& SANDA KATAVIĆ-ČAUŠIĆ
}

\begin{abstract}
The paper considers the research of the word class noun in English business magazines online, an area of interest pertaining to Business English. It presents the results of an empirical study on the corpus taken from selected business magazines online. The empirical analysis provides a valuable insight into the word class noun in this variety of Business English and makes its contribution to English syntax, semantics and morphology. The semantic part of the study identifies the most common nouns that appear in this part of Business English and underlines its semantic distinctiveness. The morphological part of the analysis is devoted to the word formation of the nouns found in the corpus. The analysis takes into consideration word formation terms such as: compounds, derivatives, conversions, acronyms and blendings. The results obtained in this way give an overall picture of the word class noun in this variety of Business English. They can act as an impetus for further research of the word class noun in Business English and enable contrastive analysis with the results from research in other segments of English for Specific Purposes.
\end{abstract}

Keywords: $\bullet$ ESP $\bullet$ word class noun $\bullet$ business magazines online $\bullet$ syntax $\bullet$ semantics $\bullet$

CORRESPONDENCE ADDRESS: Borislav Marušić, PhD, Senior Lecturer, University of Applied Sciences Lavoslav Ružička in Vukovar, Županijska 50, Vukovar, Croatia, e-mail: bmarusic@vevu.hr; Sanda Katavić-Čaušić, MSc, Lecturer, Faculty of Economics in Osijek, Trg Lj. Gaja 7, Osijek, Croatia, e-mail: sanda.katavic.causic@efos.hr. 


\section{$1 \quad$ Introduction}

The study of words and word classes is central to many linguistic theories and it is one of the fundamental linguistic notions since all words of a language are divided into word classes. Linguists have been classifying words for a long time and they have generally been taken for granted, however, defining them is a difficult endeavour. Out of the total of eight word classes in traditional grammars, nouns compose a very productive class. Moreover, they are the largest category that is continually enriched by word-formation and one that is especially present in the contemporary business environment. Therefore, it can be stated that the importance of nouns is grammatically and semantically unquestionable. In the English language they linguistically belong to a large, open word class together with members of three major open classes: verbs, adjectives and adverbs; however, their respective proportion varies according to different sources. The main characteristic of the noun category is the fact that this class is very large, accounting for about $50 \%$ of the total number of words included in the Oxford English dictionary. On the other hand, the proportion of noun word class in the Brown and LOB corpora across both spoken and written English varies between 36 and 37\% respectively (Hudson, 1994, p. 332). Despite numerous descriptions of the noun class, it is quite demanding to provide a concise definition of it without considering its morphological, syntactic and semantic characteristics. However, nouns are referred to as words that identify the whos, wheres, and whats in language, and they predominantly name people, places, and things. As in the digital era new technologies, concepts, products and experiences appear constantly, in order for the English language to meet contemporary communication needs and challenges new words and particularly members of the noun class emerge all the time, and this is especially typical of the domain of global business.

For the purpose of this paper, a selected corpus of English business magazines online has been selected in order to examine examples of relevant usage of nouns, since their contribution to the message through the content is of outmost importance. As a relevant illustration, exactly newspaper headlines are very frequently structurally ambiguous because of the lack of definite part-of-speech markers (Rayevska, 1976). Moreover, as Delahunty and Garvey (2010, p. 148) continue, the content words (among which exactly the nouns take the central position) "are the ones that we see in newspaper headlines where space is at a 
premium". Consequently, the research is rooted in the obvious need and importance of studying ever-evolving business vocabulary with focus on noun formation. The information provided, as well as the frequency of nouns in the corpus is rooted in general information about the nature of word class noun.

We believe that the results of this study will be of value in word-oriented language teaching approach across the curriculum, and that valuable insights obtained from the research can contribute to the correct use of discipline-specific vocabulary in the noun class. Due to constant emergence of new words, especially in the domain of international business, and the need for broad knowledge of contemporary business vocabulary, more research on business English corpora is needed, since it can facilitate the integration in ESP setting.

\section{Theoretical framework}

Though seemingly an ordinary aspect of language, boundaries between words have always been of major interest in linguists' endeavours to study their modifications and grouping in accordance with their distinct features, grammatical properties or what they 'do' in a sentence. Polinsky (2004, p. 1) claims that distinction of word classes has long attracted researchers of language, and they are also central to corpus linguistics. However, grammarians' attitude towards their respective classification has changed a lot over time (Rayevska, 1976). The contemporary linguistic view has introduced the term word category, grammatical category, lexical and syntactic category or simply word class replacing therewith more traditional term part of speech. What is generally understood by the terminology is not unanimously agreed on, but common properties or similar behaviour of the members within particular taxonomic category and the part they play in a sentence are the indisputably accepted facts. In terms of attempting to define them Delahunty and Garvey (2010, p. 150) claim that parts of speech need to be defined accurately in order to determine which categories words belong to, as well as their inflections, and roles in phrases and sentences. Gärdenfors (2014, p. 181) opposes the existence of a universal definition of word classes, which can be supported by the argument that defining word classes is extremely difficult, especially when considered in isolation as they can be recognized only by their contextual use (Buljan \& Gradečak-Erdeljić, 2013, p. 29). The mentioned authors add that there is no single way in classifying word classes, as boundaries between them are often fluid, and each part of speech comprises many sub-categories. Furthermore, many words belong to more than one class, since their respective 
heterogeneity is based on unequal morphological, syntactic, semantic and phonetic properties of words, i.e. criteria applied in the classification.

Linguists often disagree on the overall number of such categories (ibid., 9), and according to Delahunty and Garvey (2010, p. 77) the words have traditionally been classified into eight classes in English: nouns, verbs, adjectives, adverbs, prepositions, pronouns, articles and conjunctions. However, Rijkhof (2007, p. 1) adds two more categories, numerals and articles, claiming that grammatical description of words adapted by most English dictionaries classifies words into 10 traditional categories. On the other hand, Francis (in Rayevska, 1976, p. 67) claims it is necessary to identify four different word classes, or three according to Dixon (2005, p. 8), who excludes adverbs. Their respective importance can be supported by the fact that language universal distinction of nouns, together with verbs and adjectives, makes these typological prototypes particularly useful for communication due to universal patterns in human cognition (Gärdenfors, 2014, p. 181).

The major grammatical feature of word classes is their membership to the lexical or major word classes (nouns, verbs, adjectives and adverbs) and the grammatical or minor ones (prepositions, pronouns, articles and conjunctions). Accordingly, lexical word classes belong to open classes or content words, whereas grammatical ones belong to closed classes or function words. Open-class items carry the meaning, provide the primary lexical content, hence the previously mentioned term 'content words'. The class is open-ended, extremely large in number and has potentially unlimited membership. Therefore, it can be enriched by word-formation (Lehman, 2011, p. 26), and it is continually updated by new words which arise for communicative reasons, or as Rajarajeswari and Mohana (2013, p. 6) claim, due to "a need for it or a consciousness that no existing word is really adequate to fill that need". In contemporary sociolinguistic contexts words evolve and change, and new words appear constantly due to developments in technology, scientific discoveries, new products and contemporary concepts. Hence, in order to define them adequately, it is crucial to be aware of the distinction between different word classes and a set of criteria needs to be considered, i.e. morphological, semantic, syntactic, phonetic and word-making characteristics. 
Nouns as a word class

Across many world languages nouns represent central lexical units composing one of the great taxonomic classes and being, probably, the most important one. In the English language they are one of the four dominant word classes next to verbs, adjectives and adverbs, all of which are "capable of making direct reference and are the main units which carry the burden of referential information" (Rayevska, 1976, p. 68). The word class noun is a language-specific category and in English it is the dominant category with more words than all other categories together. In other words, out of the estimated total number of words amounting to more than a million, and more specifically, out of the 171,476 words in current use and around 9,500 derivative words included as full entries or subentries in the Oxford English Dictionary, over one half are nouns. Based on the wordclasses analysis in the Brown and LOB corpora of written English, the overall figures for the word-classes are very similar, whereby the proportion of the noun word class English varies between 37\% and 36\% respectively (Hudson, 1994, p. 332). Hence the generalization that nouns constitute about $37 \%$ of word-tokens (ibid.). As the extent of grammatical differentiation between them may show a considerable amount of variation (Payne et. al., 2010, p. 29), so should the attempt to describe the nature of nouns consider different criteria. Their semantic, morphological and syntactic characteristics are essential to distinguish them as a separate word class are their semantic, morphological and syntactic characteristics.

The word 'noun' has its origin in Latin nomen meaning "name, noun" and it refers to the name of a specific thing or things. As it, hence, possesses the grammatical meaning of thingness it can be supported by the claim that the lexico-grammatical meaning of the noun indicates "substance" (Rayevska, 1976, p. 72). In terms of semantic properties or functions, there are different possible definitions of nouns, but a meaning-based definition says that nouns are traditionally viewed as words that name persons, places, ideas, and things (Delahunty \& Garvey, 2010, p. 78). However, Gärdenfors (2014, p. 184) claims that linguists are generally not satisfied with this kind of description, since it is difficult to specify a complete list of categories. Additionally, the definition does not cover nouns which do not have any physical referents, i.e. abstract nouns. With the aim of differentiating between concrete and abstract nouns, Lyons (in Gärdenfors, ibid.) introduces a three-way typology comprised of 1. physical objects, 2. events, processes, statesof-affairs, and 3. abstract entities and prepositions. With reference to the 
previously mentioned, the two special classes can be determined: concrete nouns, that name things, refer to people and things that exist physically or can be perceived with one of the five senses, and abstract ones that name things that are not concrete or cannot be perceived with the senses. Types associated with the grammatical class nouns proposed by Dixon $(2005$, p. 82$)$ are expanded, and as the author provides the following taxonomy consisting of five major types: concrete reference, abstract reference, states and properties, activities and speech acts.

By their meaning or semantically, nouns can be divided into several subcategories using different classification criteria which, according to Buljan and GradečakErdeljić (2013, p. 32) "reflect similarities in their respective meanings and behaviour". They can be grouped according to the type of nomination into two grammatically different groups, i.e. proper and common nouns. The same authors continue that proper nouns are used to "refer to individuals that are presumed to be uniquely identifiable by the speaker and the hearer in the context of communication" (ibid.). Common nouns, on the other hand, refer to classes of entities with similar characteristics and identify the general varieties. Then, regarding their form of existence nouns can be divided into animate, referring to human and non-human creatures, and inanimate, referring to a thing or concept. Finally, according to their quantitative structure, nouns can refer to either entities that can or cannot be counted and are for that reason called countable and uncountable nouns respectively. A subcategory of countable nouns are collective nouns that name a group, collection or number of people or things consisting of more than one member, or, in other words, refer to a group of countable nouns as a unit, and, depending on the behaviour of the members of the group, can be singular or plural depending on the context of the sentence.

Morphologically or regarding the grammatical categories which categorize nouns as a word class, there are formal characteristics of nouns: number, case and articles. In English a number implies the contrast between the idea of 'one' and 'more than one' (Buljan \& Gradečak-Erdeljić, 2013, p. 51), or, in other words, between singular and plural forms, whereby this distinction categorizes nouns into two classes: invariable and variable nouns. Morphological change is typical of variable nouns that can be both singular and plural, but not of invariable nouns, which can be either singular or plural. A distinction that needs to be made is also between regular and irregular plurals. Regular plural represents a morphological 
change that takes place with variable nouns whereby they get the inflectional suffix $-\mathrm{s}$; on the other hand irregular plurals adopt changes typical of English grammar, or borrow plural forms from foreign nouns. As for the case category, their number depends on the linguistic approach. Whereas Old English distinguished four cases (nominative, genitive, dative, accusative), some grammarians mention three (nominative, objective and possessive); however, nowadays, as Buljan and Gradečak-Erdeljić state (2103, p. 117), case inflections have been reduced to a bare minimum so that the most common view today is based on the existence of only two cases: a nominative (common) and genitive (possessive) one. The former is considered to be unmarked, whereas the latter marked and through the only surviving case marking in nouns referred to as 'the genitive clitic' by the above authors (ibid.) or just the -'s inflection which spread in present-day English at the expense of the synonymic presence of the of-phrase (Rayevska, 1976, p. 83). Regarding the presence of articles with nouns Francis argues in his analysis (as cited in Rayevska, 1976, p. 67), that the most common noun-marking signal is a group of function words called noun-determiners that precede the noun, the mark and among which exactly the article is "a typical morphological category, a special function-word used as an overt marker of the noun and contributing to its meaning" (ibid., p. 84). As for the gender in the English language, Rayevska (1976, p. 72) argues that in modern English there is no grammatical gender, whereas Buljan and Gradečak-Erdeljić (2013, p. 99) claim, that it is an insignificant category and that "English nouns are limited in their capacity to signal gender".

\subsection{Noun functions}

The syntactic criteria classify nouns in terms of several important functions pertaining to them. These functions refer to certain characteristic positions in relation to other identified parts of speech in phrases and utterances. Nouns can function as:

1. Subject - tells 'who' or 'what' about the verb:

The economy is expected to grow this year.

2. Subject complement (predicate nominative/noun) - renames or defines the grammatical subject of the sentence:

He was an excellent leader. 
3. Direct object - answers 'whom' or 'what' after an action verb:

The salesperson wrote the report.

4. Indirect object - tells 'to whom' or 'for whom' the action is done:

The managers assigned his employees a new project.

5. Object (objective) complement - renames or describes (equals) the direct object, it gives further meaning to it:

Ms Smith was named temporary chairwoman.

6. Object of preposition - when combined with a preposition, it forms a prepositional phrase:

You can talk to the candidate.

7. Noun of direct address - the name or word by which someone is addressed:

Team, I want all of you here tomorrow on time.

8. Appositive - explains a noun preceding it:

Mr Jones, the company CEO, is absent this week.

\subsection{Noun formation}

Due to the productive nature of English, the fact that new lexicon is created, resulting from diverse word formation processes applies also to English. Apart from monomorphemic words of the noun class consisting of only one morpheme or simplex nouns, there are two basic types of word-formation in the English language and these include word-composition and word-derivation. The vast majority of new nouns, hence, can be formed by compounding and derivation and, according to Curme $(1965$, p. 12) there are:
a) compound nouns
b) derivative nouns.

The practice of stringing or combining a group of two or more nouns, both common and proper ones, to form new units is very common in English (Tahaineh, 2012, p. 1109). New combinations of nouns are invented almost daily in order to describe things, events or ideas that have not existed before, without 
the need to make any structural changes to the grammar of nouns. The basic part of the compound (determinatum), which expresses a general meaning, is preceded by the determining one (determinant), which changes the modification by the basic part. Hence, the first word modifies or identifies the second word, the second word identifies the item. The meaning of compound nouns is different, or more specific, than the two separate words. Tahaineh also adds (ibid.) that among the four principal types of compounds in English, compound nouns form the major group comprising four kinds of compounds: (a) exocentric compounds (the compound is not a hyponym of the grammatical head), (b) endocentric compounds (the compound is a hyponym of the grammatical head), (c) appositival compounds (the compound is a hyponym of both elements in the compound), and the least common group in English (d) copulative compounds (the two elements of the compound are separate entities combined to refer to one entity). There are three types of compound nouns: 1. 'open' compound nouns form the majority of compound nouns and are not hyphenated (web page, fellow employee, voice mai $)$, 2. 'closed' or 'solid' nouns are completed or joined to form a single word (checkbook, notepad, whiteboard), and 3. 'hyphenated' (vicepresident, check-in, editor-in-chief). There are generally no specific rules for hyphenation or space use in compound nouns, and sometimes all three forms are acceptable in English. According to the Longman grammar of spoken and written English (1999, 325f.), noun compounds can comprise the following combinations:

1. Noun + noun: bar code, database

2. Noun + noun/verb-er: eye-opener, bousekeeper

3. Noun + verb-ing: window shopping, film-making

4. Adjective + noun: whiteboard, real estate

5. Verb + noun: cookbook, breakfast

6. Verb-ing + noun: printing-press, driving licence

7. Verb + particle: handout, checkout

8. Particle + verb: outsource, income

9. Self + noun: self-help, self-control

Derivatives result from the most common word formation process called derivation or affixation, which is, according to Tahaineh (2012, p. 1108), achieved by means of a large number of small bits called affixes (prefixes and suffixes), which make a whole new word out of the word it attaches to, change the basic meaning of the word or the word class. In this sense, the affixation signifies the 
process of derivation as the noun formation process, which is, according to Tahaineh (201, p. 1108), much less regular and predictable, and hence more demanding to memorize than inflectional morphology. As for the affixes, Biber et.al. claim (1999, p. 319) that they "vary in frequency and productivity, i.e. the extent to which they are used to build new words". Derivation can be achieved in two ways: by adding prefixes to a noun base, whereby the meaning alters but the word class remains unchanged, or suffixes to a verb or adjective base to form a noun with a different meaning, whereby the word class often alters. As lexicalized units, prefixed nouns may acquire meanings which cannot be fully understood by combining the meanings of the prefix and the base, whereby the prefixes might vary regarding the preference for hyphenation. In terms of their frequency and productivity, noun derivational suffixes dominate over the prefixes.

\section{Derivational prefixes}

Most of the noun-forming prefixes overlap with the prefixes used for forming adjectives and verbs. As in other word classes many prefixes of foreign origin (e.g. Latin, Greek or French) have been completely incorporated in noun formation processes. Longman grammar of spoken and written English (1999, p. 320) provides a list of thirty-four different prefixes as follows: anti-, arch-, auto, bi-, bio-, co-, counter-, dis-, ex-, fore-, hyper-, in-, inter-, kilo-, mal-, mega-, mini-, mis-, mono, neo-, non-, out-, poly-, pseudo-, re-, semi-, sub-, super-, sur-, tele-, tri-, ultra-, under-, vice-. The tendency to attach prefixes to root nouns with hyphens is almost avoided in contemporary English, though prefixes ex- and self- (as in ex-colleague or selfcriticism) are obligatory in this form.

\section{Derivational suffixes}

Suffixation of nouns, verbs and adjectives is a common way of forming new nouns by means of adding various endings. This subcategory of derivative nouns is formed by adding a suffix to a common or proper noun, verb or adjective, which in many cases was originally an independent word (Cume, 1965, p. 12). Some common suffixes are: -ment, -ness, -ship, - dom, -ity/-ty, -hood, -th, -er, -eng, -ess, -ist, including a group of diminutive endings also used to express endearment: kin, -ling, -ette, -let, -ie, -y. Unlike prefixes, suffixes frequently alter the word class; hence, among four main distinguishable types of suffixes, those forming nouns 
can be divided into following subgroups depending on the word class they are derived from:

a) Denominal nouns $(\mathrm{N} \rightarrow \mathrm{N})$ : -hood, -ship,-er, -ant, -kin, -ling, -ette, -let, -ie, $y$, -ist:

booklet, New Yorker, accountant

b) Deverbal nouns $(\mathrm{V} \rightarrow \mathrm{N})$ : -er, -or, -ment, -ion, -tion, -sion, -ing:

manager, organisation, mobbing

c) Deadjectival nouns $(\mathrm{A} \rightarrow \mathrm{N})$ : -ness, -ity, -ance, -ment:

fitness, punctuality, tolerance

In the case of zero derivation, i.e. where derivational morphological processing is not distinctly marked, category change or functional shift takes place, which is also referred to using a distinct term - conversion. Therewith, according to Quirk (in Hernández \& Mendiluce Cabrera, 2005) the process is like deriving or transferring a word into another morphological category with a zero-affix, thus creating a semantic dependence of one word upon another. This is a productive and easy way to create new words, in our case nouns from adjectives and verbs. There are many derived nouns that have no derivational endings, which comes as a result of zero derivation (Delahunty \& Garvey, 2010, p. 152). Moreover, Biber et. al. (1999, p. 319) state that the noun acquires more specific meanings with conversion, providing examples like: hopefuls (zero-derived noun meaning someone who is Adj.) from adjectival base form hopeful as in 'presidential hopefuls', or a cheat (zero-derived noun meaning someone who V-s) from verbal base form cheat as in 'accused of being a cheat'. In order to determine whether a word has undergone zero derivation or conversion to form a noun, Delahunty and Garvey (2010, p. 150) suggest applying an analytic test by adding the plural inflection spelled $-s$ or - es (updates, wipeouts, snaps).

\section{$4 \quad$ Method and Hypotheses}

This paper contains the results of a scientific corpus-based research. The authors of the paper are of the strong opinion that only a corpus-based study can provide objective data on the segment of the language in question. The corpus is comprised of corpus findings from the following English business magazines online: The Economist, Forbes, Fortune and TheStreet. 
At the beginning of the research we put forward the following hypotheses:

1. The frequency of nouns in the corpus of the English business magazines online is higher than in the corpus of news. We suppose that this variety of Business English makes greater use of nouns, since it belongs to the LSP, compared with the general language of news analysed in the corpus from Longman grammar of spoken and written English.

2. There is an increased frequency of numbers premodifying nouns within noun phrases in the corpus. We formulated this hypothesis, as this variety of Business English tends to express various amounts, quantities, ratios and percentages.

3. There is an increased number of acronyms in the corpus of the English business magazines online. We hypothesize this since the English business magazines online belong to the register of Business English. As a variety of LSP, the language of the English business magazines online makes use of this type of abbreviated words due to language economy, according to which the existing content needs to be expressed in as few words as possible.

\section{$5 \quad$ Research and Discussion}

A total of 399 sentences comprised the corpus containing 8,236 words, what makes 20.64 words a sentence. There are 1,999 nouns in the corpus, which makes 5.01 nouns a sentence. Expressed as a percentage of the total number of words, $24.27 \%$ of the words in the corpus belong to the word class noun. According to the Oxford English Dictionary, there are more than a half of the words belonging to the word class noun. When it comes to corpus evidence, the Longman grammar of spoken and written English shows the following distribution of the main word classes in the corpus of news: nouns - 325,000 words per million, verbs $-100,000$ words per million, adjectives $-60,000$ words per million, adverbs - 85,000 words per million. Compared with the results from the corpus of the English business magazines online, the results are as follows: 
Table 1: Frequency of the word class noun in the English business magazines online and in corpus of news

\begin{tabular}{|c|c|c|c|}
\hline $\begin{array}{c}\text { Corpus of news } \\
\text { (occurrences per million } \\
\text { words) }\end{array}$ & Percent & $\begin{array}{c}\text { Corpus of the English } \\
\text { business magazine online } \\
\text { (occurrences per million } \\
\text { words) }\end{array}$ & Percent \\
\hline 325,000 & 32.5 & 242,732 & 24.27 \\
\hline
\end{tabular}

The data on frequency of the word class noun in the corpus of English business magazines online did not confirm our first hypothesis that claimed that the frequency of nouns in the corpus of English business magazines online is higher than the one of the corpus of news. The Longman grammar of spoken and written English (1999, p. 231) states that nominal elements (the whole noun phrases) make up about $80 \%$ of the text in the corpus of news.

There are 554 nouns which come up in plural. Additionally, the following examples of pluralia tantum can be found in the corpus: Millennials (6 corpus findings), financials, Treasuries (2 corpus findings each), clothes, collectibles, customs, metrics and securities, so that the overall number of plural nouns amounts to 613 corpus findings, which makes up $30.66 \%$ of the nouns. 
The following table shows the most frequent nouns in the corpus of English business magazines online:

Table 2: The most frequent nouns in the English business magazines online

\begin{tabular}{|l|c|}
\hline Noun & $\begin{array}{c}\text { Number of corpus } \\
\text { findings }\end{array}$ \\
\hline dollar & 66 \\
\hline stock & 36 \\
\hline China & 31 \\
\hline year & 29 \\
\hline price & 26 \\
\hline company, trade & 24 \\
\hline market & 23 \\
\hline time & 22 \\
\hline tariffs & 20 \\
\hline investor, share & 19 \\
\hline growth, world & 18 \\
\hline bank, billion, product & 17 \\
\hline money, yield & 15 \\
\hline America & 14 \\
\hline investment, state(s) & 13 \\
\hline delivery & 12 \\
\hline business, report & 11 \\
\hline rate, wealth & 10 \\
\hline consumer, quarter, value & 9 \\
\hline million, officer & 8 \\
\hline economy, imports, portfolio, record & 6 \\
\hline administration, asset, capital, earnings, equity, & 5 \\
interest, return, war & 4 \\
\hline cent, investing, profit, research, revenue, strategist & 3 \\
\hline disease, increase, innovation, loss, management, \\
reality, reserve, safety & 2 \\
\hline & \\
\hline
\end{tabular}


According to the data from the Corpus of Contemporary American English containing 450 million words, the following twenty nouns are the most frequent ones: time, year, people, way, day, man, thing, woman, life, child, world, school, state, family, student, group, country, problem, hand and part. Taking into account the results obtained in our research, it could be concluded that there is a strong semantical shift of nouns in the English business magazines online from those in general English. The nouns in the English business magazines online show a strong tendency towards semantical belonging to the register of Business English, since there are only three overlapping nouns among the first twenty in the two corpora. It is interesting to highlight the nouns denoting two countries: China and America. Although an outside observer would think they belong to the register of general English, people dealing with business know well, that the whole world's economic system rests upon the relationship between the biggest world players, two of which are America and China.

Most nouns from the corpus occur in the head position of noun phrases (NPs). The number of premodified nouns in the corpus is more numerous than the ones being postmodified, since this variety of Business English tends to give additional pieces of information about the given noun in front of the noun by building complex noun phrases. There are several types of determiners in the corpus:

1. Article (definite - the; indefinite $-\mathrm{a} / \mathrm{an})$

2. Pronouns (demonstrative, possessive, interrogative, relative and indefinite)

3. Saxon genitive (manager's income).

Their distribution is shown in the following table:

Table 3: Determiners within NP in the English business magazines online

\begin{tabular}{|c|l|c|c|}
\hline & Determiner & $\begin{array}{c}\text { Number of corpus } \\
\text { findings }\end{array}$ & Percent \\
\hline \multirow{3}{*}{1.} & Article & 565 & 68 \\
\cline { 2 - 4 } & Definite article & 374 & 45 \\
\cline { 2 - 4 } & Indefinite article & 191 & 23 \\
\hline 2. & Pronoun & 201 & 24 \\
\hline 3. & Saxon genitive & 63 & 8 \\
\hline & Total & $\mathbf{8 2 9}$ & $\mathbf{1 0 0}$ \\
\hline
\end{tabular}


Here are several examples of Saxon genitive from the corpus: Warren Buffett's largest porffolio holdings, Apple's growth prospects, today's retail environment, the sector's recovery, Chipotle's new CEO, Boeing's defense business, America's total imports. These extracts put a strong emphasis on the corpus being semantically related to Business English.

There are several types of premodifiers in the corpus: adjectives, nouns, numbers and adverbs. Their distribution is given in the following graph:

Their distribution is given in the following graph:

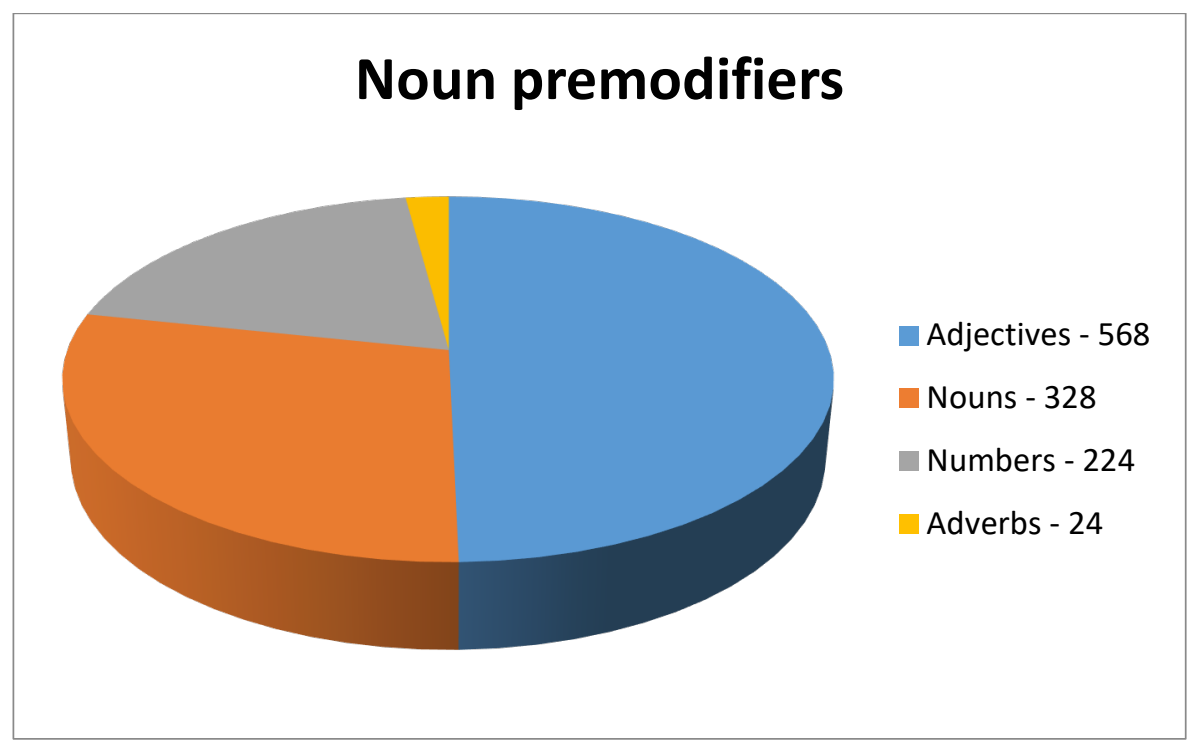

Graph 1: Premodifiers within NP in the English business magazines online

The 224 numbers premodifying the nouns confirm our second hypothesis in which we put forward, that there is an increased frequency of numbers premodifying nouns within noun phrases in the corpus, due to a trait of Business English to express various amounts, quantities, ratios and percentages.

There are eight adjectives postmodifying the heads of the NPs: an area north of ..., a decision based on ..., a gain estimated ..., a method much more popular..., a Range Rover convertible..., stocks worth..., the costs involved ..., work involved... 
When it comes to word formation of the nouns in the corpus, the following derivations with derivational prefixes and suffixes can be observed:

Table 4: Derivations in the English business magazines online

\begin{tabular}{|l|c|l|c|}
\hline $\begin{array}{l}\text { Derivational } \\
\text { prefixes }\end{array}$ & $\begin{array}{c}\text { Number of } \\
\text { corpus } \\
\text { findings }\end{array}$ & $\begin{array}{l}\text { Derivational } \\
\text { suffixes }\end{array}$ & $\begin{array}{c}\text { Number of } \\
\text { corpus } \\
\text { findings }\end{array}$ \\
\hline re- & 46 & -er & 48 \\
\hline in- & 14 & -ment & 38 \\
\hline dis- & 7 & -ity/-ty & 32 \\
\hline sub- & 4 & -er & 32 \\
\hline fore- & 2 & -ness & 13 \\
\hline inter- & 2 & -ist & 12 \\
\hline vice- & 2 & -ship & 4 \\
\hline semi- & 1 & -hood & 1 \\
\hline super- & 1 & -ie & 1 \\
\hline sur- & 1 & & \\
\hline tele- & 1 & & $\mathbf{1 8 1}$ \\
\hline Total & $\mathbf{8 1}$ & & \\
\hline
\end{tabular}

There are totally 262 derivations in the Corpus of English business magazines online. The most common derivations with prefixes are: report -11 , record -6 , return -5 , investing, research, revenue -4 , disease, increase, innovation, reserve -3 . The most common derivations with suffixes are: growth - 18, business - 11, investment13, wealth - 10, equity -5 , strategist - 4, management, reality, safety -3 . 
The distribution of noun compounds according to their type is shown in the following graph:

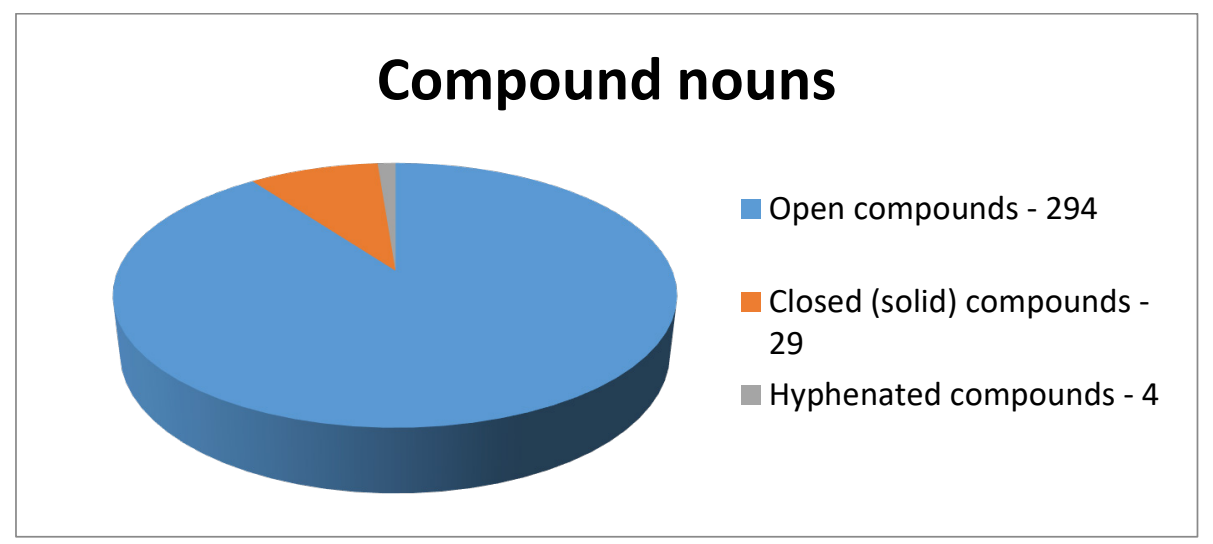

Graph 2: Types of compound nouns in the English business magazines online

The vast majority of the compound nouns belong to the open compounds category, i.e. they consist of two separated nouns. The following closed compounds can be found in the corpus: Airbus - 5 corpus findings, benchmark 3 corpus findings, portfolio, airplane - 2 corpus findings each, aircraft, bombshell, chairman, coursework, doordash, doorstep, FaceTime, gangbuster, headline, hopekids, mindset, Morningstar, popcorn, shockwave, videotape, wholesale, workforce. The following four compounds from the corpus belong to the hyphenated compounds: Coca-Cola, eye-opener, roulette-wheel, side-effect. There are several compounds from the corpus denoting names of the companies and applications: Coca-Cola, Morningstar, FaceTime. 
The English in business magazines online makes extensive use of language economy in such a way that it uses a lot of acronyms to form sentences. It is another example of economizing on words within a sentence. The overwhelming majority of the acronyms are strongly semantically related to Business English.

Table 5: Acronyms in English business magazines online

\begin{tabular}{|c|c|c|}
\hline Acronym & Full term & $\begin{array}{l}\text { Number of } \\
\text { corpus } \\
\text { findings }\end{array}$ \\
\hline $\mathrm{BMO}$ & Bank of Montreal & 1 \\
\hline CEO & Chief executive officer & 7 \\
\hline CGI Group & Canadian Government Intelligence Group & 1 \\
\hline CIBC & Canadian Imperial Bank of Commerce & 1 \\
\hline $\mathrm{CNBC}$ & Consumer News and Business Channel & 2 \\
\hline D.C. & district & 1 \\
\hline EBIT & Earnings before interests and taxes & 1 \\
\hline Fed. & Federal Reserve System & 2 \\
\hline GAAP & Generally accepted accounting principles & 1 \\
\hline GBT & Global Blood Therapeutics & 5 \\
\hline GE & General Electric & 1 \\
\hline GPR Indeks & Global Property Research Index & 1 \\
\hline IBM & International Business Machines & 1 \\
\hline Inc. & Incorporation & 1 \\
\hline $\mathrm{iOS}$ & iPhone operating system & 1 \\
\hline JPMorgan & John Pierpont Morgan & 1 \\
\hline KFC & Kentucky Fried Chicken & 1 \\
\hline Ltd. & limited & 1 \\
\hline Mr. & Mister & 2 \\
\hline $\mathrm{RBC}$ & Royal Bank of Canada & 1 \\
\hline S\&P & Standard and Poor's & 1 \\
\hline TSS & Total Symptom Score & 1 \\
\hline TSX & Toronto Stock Exchange & 1 \\
\hline U.K. & United Kingdom & 1 \\
\hline U.S. & United States & 13 \\
\hline USD & United States dollar & 1 \\
\hline USTR & $\begin{array}{l}\text { (Office of the) United States Trade } \\
\text { Representative }\end{array}$ & 2 \\
\hline WTO & World Trade Organisation & 1 \\
\hline YTD & year-to-date & 1 \\
\hline
\end{tabular}


There are 8 blendings among the corpus findings, all of them related to the word Alarmcom.

\section{Concluding Remarks}

The results of the research could be used in Business English classes, where the most frequent nouns could be presented with the frequent collocations they form. That is one of the best ways to enlarge students' vocabulary. The most important fact is that such vocabulary acquisition is accomplished by means of utilizing real Business English examples. Such examples can be found in diverse dictionaries of collocations. 
Here is an example of collocations with the noun STOCK from the Oxford collocations dictionary online:

Table 6: A dictionary entry from the Oxford collocations dictionary online.

Retrieved from http://www.freecollocation.com/search?word=stock

stock noun

1 available supply of sth

ADJ.good, high, huge, large | low | adequate | declining, dwindling, falling dwindling fish stocks in the North Sea | surplus | buffer, reserve $A$ buffer stock of grain was held in case of emergency shortages. | fresh, new | old | existing | fish, food, etc. | housing The housing stock is no longer large enough for the population. | capital, money | library

VERB + STOCK carry, have, hold, keep The big supermarkets carry huge stocks of most goods. I add to, increase | dispose of, get rid of, reduce, sell off They're selling off their old stock cheap. I maintain, protect laws to protect fish stocks | replace, replenish

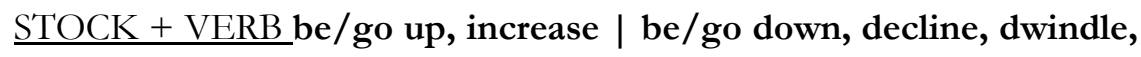
fall, run low Stocks of coal are running dangerously low. I last The offer is only available while stocks last.

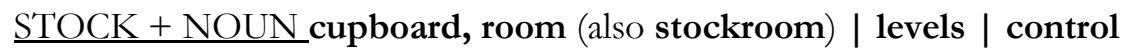
PREP. from $\sim$ We can supply the table from stock. I in $\sim$ Have you got futon beds in stock or will I have to order one? | out of $\sim$ Red tights are out of stock.

2 share in the capital of a company

ADJ. blue-chip, gilt-edged, index-linked

VERB + STOCK acquire, buy, invest in, purchase | cash in, dispose of, sell | deal in, trade | have, hold, own | issue | value The stocks were valued at $\mathrm{f}, 100,000$.

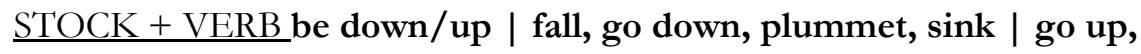
rise, soar

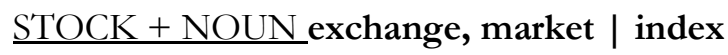

PREP. in s She's got about £30,000 in stocks.

PHRASES investment in stocks, the value of the stocks The total value of the stocks was over $\AA^{3} 3$ million. 
Another way of presenting collocations with the most frequent nouns from the corpus is using the lecturer's personal database. The authors of this paper believe that the lecturers of any ESP course should have a very profound knowledge of their teaching area. One of the ways to accomplish that goal is to create a personal comprehensive database with the most frequent collocations from various sources. We present an extract from our private database with the noun MONEY gathered from various business magazines, Business English textbooks and business media: to recoup invested money, to put money into circulation, to put money into the company, the stock of money, to pool money, to dole out money to sh, to put some money aside, to deposit money $\leftrightarrow$ to withdraw money, to keep money in an account, to be born into money, to have money to burn, to have more money than sense, money doesn't grow on trees, money talks, moneyed people, money is short / tight.

The third point is to emphasize the importance of understanding of acronyms both in general English and, more specific, in Business English. The most important Internet tools, such as wnw.abbreviations.com, could be presented in order to inform Business English students about the possibilities of understanding of acronyms. This research can serve as an impetus for further research of the word class noun and NP in Business English, as well as facilitate comparison of the same in other segments of ESP.

\section{Sources}

(2018, July 2). Retrieved from https://www.economist.com/

(2018, June 30). Retrieved from https://www.forbes.com/

(2018, July 2). Retrieved from http:// fortune.com/

(2018, July 1). Retrieved from https://www.thestreet.com/

\section{References:}

Biber, D. et. al. (1999). Longman grammar of spoken and written English. Harlow: Longman. Buljan, G., \& Gradečak-Erdeljić, T. (2013). English Morphosyntax. On Nouns, Determiners and Pronouns. Osijek: Josip Juraj Strossmayer University.

Corpus of Contemporary American English (COCA). Retrieved from https://www.wordfrequency.info/intro.asp

Curme, G. O. (1965). English grammar. New York: Barnes and Noble.

Delahunty, G. P., \& Garvey, J. J. (2010). The English Language: From Sound to Sense. Perspectives on Writing. Fort Collins, Colorado: The WAC Clearinghouse and Parlor Press. Retrieved from https://wac.colostate.edu/books/perspectives/sound/

Dixon, R. M. W. (2005). A semantic approach to English grammar. New York: Oxford University Press. 
Gärdenfors, P. (2014). A semantic theory of word classes. Croatian Journal of Philosophy. 14(41), 174-179. Zagreb: Institute of Philosophy.

Gurevich, O. et.al. (2006). Deverbal nouns in knowledge representation. Retrieved from http://www.cs.bham.ac.uk/ vdp/publications/flairs.pdf

Hudson, R. (1994). About 37\% of word tokens are nouns. Language. 70(2). 331-339. Retrieved from http://www.jstor.org/stable/415831

Lehmanni, C. (2011). The nature of parts of speech. Retrieved from https://www.researchgate.net/publication/267767933_The_nature_of_parts_o f_speech

Lehmanni,

C.

(2000).

Noun.

Retrieved

from https://www.christianlehmann.eu/publ/noun.pdf

Merriam-Webster online dictionary. Retrieved from https://www.merriamwebster.com/dictionary/adjectives

Online OXFORD Collocation Dictionary of English. Retrieved from http://www.freecollocation.com/

Oxford dictionaries. Retrieved from https://en.oxforddictionaries.com/explore/howmany-words-are-there-in-the-english-language/

Payne, J., Huddleston, R. \& Pullum, G. K. (2010). The distribution and category status of adjectives and adverbs. Word Structure. 3(1). 31-81. Retrieved from http:/ / www.lel.ed.ac.uk/ gpullum/PaynHuddPull.pdf

Polinsky, M. (2004). Word class distinctions in an incomplete grammar. Retrieved from https://scholar.harvard.edu/files/mpolinsky/files/ravid_volume.pdf

Rajarajeswari, M. \& Mohana, A. (2013). English language: Growth of vocabulary. International Journal on Studies in English Language and Literature (IJSELL). 1(1), 4147. Retrieved from https://www.arcjournals.org/pdfs/ijsell/ijsell_6.pdf

Rayevska, N. M. (1976). Modern English grammar. Retrieved from http://web.krao.kg/2_inostran/english/3.pdf

Rijkhoff, J. (2007). Word classes. Language and linguistics compass. 1(6). 709-726. Hoboken: John Wiley \& Sons.

Tahaineh, Y. (2012). The Awareness of the English Word-formation Mechanisms is a Necessity to Make an Autonomous L2 Learner in EFL Context. Journal of Language Teaching and Research. 3(6), 1105-1113. Retrieved from http://www.academypublication.com/issues/past/jltr/vol03/06/06.pdf 


\title{
Self-promotion Rhetoric and (Meta)discourse in Academic Writing - a Contrastive Study
}

\author{
NATAŠA MilivojeVić
}

\begin{abstract}
The present work identifies compares and contrasts the relevant rhetorical strategies associated with promotional (meta)discourse in articles and textbooks addressing the area of English and Serbian language and linguistics. In particular, the paper deals with various lexicogrammatical and discourse devices employed in academic discourse with the aim of establishing a common frame of self-referencing and self-promotion. The phenomenon of self-promotion significantly affects academic discourse which becomes permeated with "boosterism" and "selfadvocacy" (Swales, 2004; Afros \& Schryer, 2009). The paper takes into account a survey conducted with the group of first year students of English language and literature at the Faculty of Philosophy, University of Novi Sad. The survey evaluates published works in English and Serbian regarding various self-promoting strategies in both languages. The inquiry demonstrates that in both areas (languages) of academic discourse, researches and scholars utilize similar rhetorical strategies to promote their work: (1) positive evaluation of their own study on one hand and (2) negative evaluation of contrasting and/or dissenting views. This study reconfirms the advantage of specificity in teaching academic literacies advocated by many applied linguists and identifies actual strategies that can be incorporated into writing curricula.
\end{abstract}

Keywords: - academic discourse - (meta)discourse devices • rhetorical strategies $\bullet$ self-promotion $\bullet$ evaluation strategies $\bullet$

CORRESPONDENCE ADDRess: Nataša Milivojević, PhD, Associate Professor, University of Novi Sad, Faculty of Philosophy, Dr Zorana Đinđića 2, 21101 Novi Sad, Serbia, e-mail: natasa.milivojevic@ff.uns.ac.rs. 


\section{$1 \quad$ Introduction}

It is presently widely recognized in the contemporary relevant literature that selfpromotion in academic discourse varies across disciplines. Whereas most analysts focus on self-promotion rhetoric in natural and social sciences, the humanities have so far received much less attention. This paper aims to contribute to a more profound understanding of this specific feature of academic and research writing focusing on the area of language studies (and esp. on the area of theoretical linguistics).

The paper investigates the currently increasingly relevant phenomenon of selfpromotion in academic discourse, from the viewpoint of humanities. The research presented here takes a contrastive perspective and compares and contrasts self-promotion rhetoric along with self-promotion (meta)discourse in academic and research writing in English and Serbian.

To be able to as clearly as possible delimit self-promotion strategies from both hedging and persuasion (e.g. in academic argumentation), we start from the definition of hedging. We define hedging as any tentative language means used to avoid any definite certainty, or to mitigate strong statements and possible criticism (Swales, 2004). Even though Swales (2004) at one point denies that a "dramatically self-justificatory" tone is characteristic of recent scholarly publications, many analysts (e.g. Lewin, 2001) recognize these features as pervasive in academic communication". Further, we differentiate and delimit persuasion and self-promotion from each other by claiming that while persuasion is a rhetoric strategy used to promote an argument in academic and research (or scientific) writing, self-promotion is about promoting the Persona of the author. This can be done through three basic types of textual appeals, namely through logos, ethos and pathos, so all three will be closely taken into account in our analysis. The present work also deals with various lexicogrammatical and discourse devices employed in academic and scientific discourse with the aim of establishing a common frame of self-referencing and self-promotion. We continue to claim that the phenomenon of self-promotion nowadays significantly affects academic discourse which becomes permeated with "boosterism" and "self-advocacy" (Swales, 2004; Afros \& Schryer, 2009). 
Finally, we define the overall discourse analyzed in this work as a type of a feature-framed textual genre. Genre is hereby seen as a space where all fundamental elements of the communicative act converge and where the threefold linguistic, cognitive and cultural (socio-professional) perspectives of textual analysis can be fully developed. Thus, the notion of genre brings together critical elements in textual and discourse analysis such as the reader's profile, expectations and preferences; the communicative situation and purpose; and the socio-cultural context. For the purposes of the present research, we take academic discourse as a special case of language for specific purpose (LSP) with the frameset of genre characteristics in line with Milivojević \& Radojičić (2015). We reconsider the value of the concept of text genre in language teaching where text genre is understood to be a conventionalised and at the same time dynamic and hybrid text form that represents an interface between text and context.

In the remainder of the paper we will attempt to answer the following set of introductory theoretical questions:

1. What is self-promotion rhetoric and how do we recognize it?

2. What are its tools, elements and markers?

3. Is it allowed and/or desirable in academic discourse? Is that situation different in English and Serbian?

4. Is the intention of self-promotion in an academic text always received as it was intended?

5. Has the language of academic writing and publishing shifted into another genre?

6. Did the genre itself alter its format and characteristics?

\section{Corpus and Method}

\subsection{Corpus}

The compiled corpus that is at the base of the present analysis contains a total of 20 selected academic texts (research articles and introductory textbook chapters) on various topics in language and linguistics, published in English and in Serbian. The corpus was made of ten authentic texts in English and ten texts originally 
written in Serbian. The corpus did not contain any translated texts. ${ }^{1} \mathrm{All}$ analyzed textual material has been published between 1990 and the present. We focused mostly on article prefaces and textbook introductory chapters, since selfpromotion language by definition dominantly belongs to the logical and structural opening of any textual structure.

The research was conducted in the English Department of the Faculty of Philosophy in Novi Sad, with 70 first year students who were attending the course Introduction to Text Analysis 1 and 2 (Integrated Language Skills 1 and 2 ), during the winter and summer semesters of the school year 2017/2018. The students took part in a survey which was designed to evaluate the selected published textual works in English and Serbian regarding various specific selfpromoting strategies in both languages. This was also the basis for the theoretical and practical conclusions regarding the relevant contrastive discourse features in English and in Serbian, as well as for evaluating intention and reception of selfpromotion rhetoric in both languages.

\subsection{Method}

The survey had an evaluative and measuring character. For positive and negative evaluation true-or-false-statement method, along with yes-no-question method was used, while a five-point scale was designed for measuring the intensity and communicative force of the selected texts (also parts of texts and single sentences), with 1 being the lowest and 5 being the highest measuring point of the designed scale. All texts were filtered and evaluated via identical survey format which consisted of a short set of introductory binary evaluations that were followed by more elaborate set of measuring type questions.

The students were first asked to identify rhetoric strategies and self-promotion discourse devices in the text. Also, the identified textual structures were all evaluated in terms of logos (scientific facts and arguments), ethos (credibility of the author and promotion of generally accepted values) and pathos (aesthetic and/or emotional appeal). Then, the students were surveyed on various aspects of textual structure (lexical and grammatical cohesion, as well as information structure), and on the intention and reception of the relevant structures. Finally,

\footnotetext{
1 Translation were excluded for the purpose of avoiding potential discourse and genre transfer from either direction, English to Serbian or Serbian to English.
} 
the students were asked to identify semantic and functional equivalents of discourse markers of self-promotion in English and Serbian.

As a theoretical background for the survey, we used the metadiscourse markers as described by Hyland (2005): self-mentions, boosters, hedges, and engagement markers.

This research inquiry demonstrates that scholars utilize two rhetorical strategies to publicize their work: (1) positive evaluation of their own study and of those investigations in which the current study is grounded; and (2) negative evaluation of dissenting views. We are therefore defining self-promotion as the ascription of positive value to the reported research and supporting views and of negative value to dissenting views. Among the textual markers of self-promotion, the following were the most prominent:

1. evaluative lexis

2. boosters

3. self-mention

4. citation

5. comment clauses

6. personal pronouns (especially 1st person sg. and pl.)

7. parallel structures

8. lexical coordination

9. syntactic coordination

10. phrase and clause fronting

11. device clustering

12. discourse chunks sequencing

In the following section of the paper, we will provide a clearer theoretical and practical insight into the present analysis, along with the detailed discussions on textual examples extracted from the corpus. 


\section{Discussion and Results}

Self-promotion strategies in academic research articles have recently been investigated in rhetoric, composition, applied linguistics, and English for academic purposes (EAP). In a series of corpus-based studies applying a quantitative method in conjunction with a discourse analysis of natural and social sciences, Hyland $(2000,2005)$ described a variety of rhetorical and linguistic resources (e.g. boosters, self-mentions, citations, inclusion and fronting of specific moves) that various scholars deployed to spotlight the noteworthiness, novelty, and uniqueness of their work. Related research in the area of investigation of publishing techniques focused primarily on the first person pronouns usage. In addition to lexicogrammatical signals of promotion, syntactic constructions such as parallel structures and discourse signals such as fronted concessive clauses were also considered relevant (Lindeberg, 2004).

This section of the paper explores rhetorical devices language scholars employed as the means of self-promotion that were found in our corpus. We will present both English and Serbian corpus samples. ${ }^{2}$

In all texts under scrutiny, researchers used two main rhetorical strategies: (1) positive evaluation of their own study and of the research in which their study was grounded; and (2) negative evaluation of dissenting views. Also, most texts combined logos, ethos and pathos appeals aiming to widen the gap between their own study and of the research that (in their own view) is presented as erroneous. Therefore the concept of evaluation has to be extended beyond specific lexicogrammatical forms. Moreover, evaluation can be conveyed by a combination of various lexicogrammatical and discourse elements.

(1)The wedding of these disciplines (linguistics and computation) is $\underline{\mathbf{s o}}$ important, in fact, that I believe it will soon be difficult to carry out serious computational research in the fields of linguistics and NLP without the help of electronic dictionaries and computational lexicographic resources. $(\mathrm{CS} 1)^{3}$

\footnotetext{
2 Serbian to English translation will be provided in the footnote to the Serbian text.

${ }^{3}$ Corpus Sample 1
} 
The rhetorical practice illustrated in corpus sample (1) exemplifies the usage of the first person singular pronoun combined with boosters such as so and in fact; boosting is further intensified via lexical choices which resort to language figuration in the first line the wedding of these disciplines, but also to positive evaluation of the presented research and negative evaluation of the possible opponents: serious computational research which, according to the author is only possible within his analysis.

(2) In the pages that follow, I will try to convince you that every one of these common opinions is wrong! And they are all wrong for a single reason. Language is not a cultural artefact that we learn the way we learn to tell time or how the federal government works. Instead, it is a distinct piece of the biological makeup of our brains.

Thinking of language as an instinct inverts the popular wisdom, especially as it has been passed down in the canon of the humanities and social sciences. Language is no more a cultural invention than is upright posture. (CS2)

This passage is an example of a very strong evaluation based on lexicogrammatical devices such as specific, strong words, inserted comments, quantifiers and both lexical and syntactic boosters.

(3) O pitanjima koja će biti predmet naše pažnje obrazovani laici imaju određene predstave, ali one $\underline{\mathbf{u} \text { odsustvu pouzdanijih stručnih }}$ informacija često ostaju na nivou stereotipnih mišljenja, a u domenu višejezičnosti neretko i pukih predrasuda. Stoga ćemo nastojati (MI) da pružimo osnovna obaveštenja, ali i da ukažemo (MI) da mnoge stvari u vezi s jezicima i njihovim delovanjem na život ljudi stoje drukčije nego što se to obično misli. $(\mathrm{CS} 3)^{4}$

The corpus sample (3) is especially relevant in terms of feature-contrast between English and Serbian, as it includes the first person plural pronoun in Serbian

\footnotetext{
${ }^{4}$ Author's translation into English: On the issues brought to our attention, the common, educated reader may have certain notions in mind. Those notions, however, in the absence of certified scientific facts often form a stereotypical opinion, if not a mere prejudice. Therefore, WE will try to provide the basic facts, but also to (WE) point out that many things about language and its functioning in the life of the people who use it are different from the common assumptions.
} 
instead of first person singular which is commonly found in English as a marker of self-promotion.

To present their research in the best possible light, all of these scholars deployed primarily logos appeals. They foregrounded soundness of methodology and argumentation, plausibility of interpretation, as well as research and pedagogical/practical implications. These features form the backbone of academic communication and govern the structure and language of academic discourse and research articles. In our corpus, logos appeals were realized through various lexico-grammatical devices, as well as through lexical and grammatical cohesion. Many texts in the corpus contained ethos appeals related to the writer's reputation and/or alignment of the proposed analysis with the views accepted in the field. Personal and possessive pronouns were employed to strengthen ethos appeals. Personal credibility was also conveyed by supporting and self-citations. Haggan (2004) observes that titles of literary papers, unlike linguistics and science titles, have aesthetic merit. "Much like titles, the introductory statements of literary research articles, tended to be aimed at the aesthetic sensibilities of the reader". However, our research shows that this does happen in linguistics as well.

Regarding the overall quantification of the conducted survey, it can be summed up as follows: $64 \%$ of the students found the texts intimidating and (over) argumentative in terms of some (or all) of the three types of appeals (logos, ethos and pathos); $82 \%$ of the students identified the means of self-promotion as overlapping in the sense of intention and reception of self-promotion; $46 \%$ of the students identified discourse devices and rhetoric strategies of self-promotion as unexpected, and about $22 \%$ rendered them as inappropriate.

In the light of the discourse contrast between English and Serbian, the two compared and contrasted academic discourses exhibit the following meeting and divergence points:

1. a growing tendency toward personalized, emotionally expressive language, rather than impersonal and neutral (objective) expression;

2. English and Serbian academic and research paper discourse differ somewhat in the usage of pronouns: Serbian still allows for more "WE" that "I", as well as of impersonal reflexives; 
3. English and Serbian AD are mostly equivalent in terms of usage of selfpromotion discourse devices, and are completely identical in terms of rhetoric strategies of self-promotion.

This suggest a shift in traditional genre features of academic and research discourse in both languages, but which is more prominent in Serbian.

These findings posit a special kind of teaching motivation for language teachers at university level, as the well-established area of promotional (meta)discourse is gaining the growing relevance in academic writing and scientific research. This is now becoming a relevant part of textual academic literacy that needs to be properly introduced to the future language researches, especially to those who belong to the majority of non-native English speakers.

\section{$4 \quad$ Concluding Remarks}

The initial hypothesis of the paper is based on the idea that in various areas of language specialisation texts usually have standardised format. The language foundation of academic texts and research articles is therefore viewed as a specific feature-framed textual genre. We have therefore attempted at determining and exploring the complex relationship that exists between the characterization of this category of text (or textual genre) and what is taken to be intercultural textual competence required for textual structuring as well as for textual analysis and production in academic discourse, regarding the phenomenon of self-promotion.

Finally, as Afros \& Schryer (2009) claim "incorporating actual current strategies (of self-promotion) into the curriculum can help novice writers make informed judgments about promotional (meta)discourse in disciplinary appropriate ways". The present study also reconfirms the advantage of specificity in teaching academic literacies advocated by many theoretical and applied linguists alike and identifies actual problems and analytical strategies that can be incorporated into writing curricula at tertiary level of education. 


\section{Acknowledgments}

I would like to thank the Department of English, University of Novi Sad for providing the setting for the series of ongoing language projects within the $1^{\text {st }}$ year courses ILS1 and ILS2. I also thank the two anonymous reviewers for their helpful suggestions and comments on the previous versions of the article.

\section{References}

Afros, E., \& Schryer, C. F. (2009). Promotional (meta)discourse in research articles in language and literary studies. English for Specific Purposes, 28, 58-68.

Haggan, M. (2004). Research paper titles in literature, linguistics and science: Dimensions of attraction. Journal of Pragmatics, 36, 293-317.

Hyland, K. (2000). Disciplinary discourses: Social interactions in academic writing. Harlow: Longman.

Hyland, K. (2005). Metadiscourse: Exploring interaction in writing. London/New York: Continuum.

Lewin, B. A. (2001). From hedging to heightening: Toning down and up in scientific texts. Melbourne Papers in Linguistics and Applied Linguistics, 1, 17-28.

Lindeberg, A. C. (2004). Promotion and politeness: Conflicting scholarly rhetoric in three disciplines. $\mathrm{A}^{\circ}$ bo: $\mathrm{A}^{\circ}$ bo Akademi University Press.

Milivojević, N., \& Radojičić, S. (2015). Enhancing intercultural competence through genre and culture markes in textual analysis. In T. Kužič, D., Pleše, \& A. Plićanić Mesić (Eds.), Proceedings of the $8 \mathrm{~h}$ International Language Conference on the Importance of Learning Professional Foreign Languages for Communication between Cultures, Full Papers (pp. 145-155). Zagreb, Croatia: University of Zagreb.

Swales, J. M. (2004). Research Genres: Explorations and Applications. Cambridge, UK: Cambridge University Press. 


\title{
Deviation from Established Standards in LSP: Simplification or Complication?
}

\author{
OLgA I. OPARINA
}

\begin{abstract}
English has become "lingua franca" in the field of professional communication. Although there are different variants of LSP based on historical and cultural traditions, there has always existed the desire to work out unified rules of "effective communication". One of the attempts was made by H. Spencer in the essay "The Philosophy of Style". The article considers some of Spencer's statements regarding vocabulary, sentence structure and general organization of the text. The suggested by H. Spencer techniques are viewed within the framework of modern professional communication in the Internet. Some methods are used to make information comprehensible and easy for interpretation, the implementation of others is the issue for discussion.
\end{abstract}

Keywords: - academic communication - comprehension - $\mathrm{H}$. Spencer $\bullet$ information delivery $\bullet$ to be effective in understanding $\bullet$

CorReSPONDENCE AdDress: Olga I. Oparina, PhD, Senior Lecturer, Lomonosov Moscow State University, Faculty of Computational Mathematics and Cybernetics, GSP-1 Moscow, Lenin'sHills, 2nd Building, RussianFederation, e-mail:oloparina@yandex.ru. 


\section{$1 \quad$ Introduction}

Nowadays English as the language of international communication in science and humanities is often considered as "Lingua Franca" (ELF) uniting people with various native languages into one pool. As far as Academic Discourse is concerned, it is worth mentioning that "discourse reflexivity is central to academic discourse, and particularly relevant for academic ELF, where it can help increase clarity and explicitness among speakers from different linguistic and cultural backgrounds” (Mauranen, Hynninen, \& Ranta, 2016, p. 46).

The basic goal of academic discourse is to share information and knowledge. Hence, the task is to facilitate the process of knowledge acquisition and to make it more effective.

Academic discourse in all native languages is highly standardized and formalized. These are the unified rules and requirements to insert the new content into settled format. The reason for such unification is to work out universal rules aimed at simplifying the information exchange (i.e. perception, comprehension, interpretation, feedback) and presentation. Settled templates are conformed to a certain algorithm of information perception, in other words, "an addressee friendly algorithm" is created.

\section{$2 \quad$ Background}

\subsection{Various Traditions of "Intellectual Styles"}

There are various traditions of "intellectual styles" originated from the history of academic style evolution. Many scientists stress these differences. As A. Duszak noted referring to other scholars: "Western cultures are individualistic and hence supportive of direct, assertive, and explicit verbal styles. Oriental societies, on the other hand, emphasize collective values and group harmony; their members, rather than speaking boldly and unambiguously, engage in an affective style of communication, trying to defend themselves by vague expressions or by not talking at all. $<\ldots>$ Hinds claims that in Japan, it is responsibility of the listener / reader to find out what the speaker / writer wants to communicate" (Duszak, 1994, p. 294). The author explained it by historic traditions in the countries. As 
the illustration A. Duszak highlighted the politeness of Japanese writing, and she added that they tried to avoid debate not to hurt the feelings of the opponent.

A.Duszak also takes into consideration M. Clyne's ideas on differences concerning German and Anglo-Saxon traditions (Clyne, 1987). According to this viewpoint, Anglo-Saxon style presents the material as thought out, while German style is "cryptic and elitistic, the reader must make an (extra) effort while engaging in academic communication (Clyne, 1981; Duszak, 1994, p. 294). Speaking about Russian style of academic communication A. Duszak mentions the German impact on Russian Academic tradition but the suggested reason of this influence is rather doubtful. She explained it by "long historic tradition, in particular of the philosophy of Karl Marx” (Duszak, 1994, p. 295). In fact, the reason is drastically different - Russian system of education, particularly higher education, was borrowed from the system of German universities. Lomonosov Moscow State University, established as the first universityin Russia from the start, was founded in 1755, long before K. Marx and his philosophy. The system of university education formed the style of intellectual communication.

Moreover, many other historical events have influenced intellectual styles in the countries. Some of these events occurred in one country or a group of countries, others have international impact.

\section{2 "Practical Rhetoric"}

Standards, changes of the standards, the search for better ways of knowledge presentation for better comprehension - all these issues were in the focus of some scientists (not only scholars) when the necessity of knowledge dissemination and elimination of educational differences occurred. The period of time when world science faced these challenges was the middle of the XIX century. That epoch was characterized by a lot of technological advances based on scientific achievements. Hence, the gap between the idea and its practical implementation should have been less. The result - intellectual communication must be accessible, effective and easy for comprehension. Hence, the style and essence of rhetoric changed.

As James P. Zappen noted "eventual demise <of classical rhetoric $>$ and its replacement by the so-called practical rhetorics" (Zappen, 1991, p. 146). The most important thing stressed by the scholar that "science and scientific rhetoric also 
served broader social communities and that, $\langle\ldots\rangle$, scientific rhetoric remained inseparable from its modes of inquiry and from the social communities it sought to serve, and language remained inseparable from science and civilization" (Zappen, 1991, p. 146). Science, some of its methodology and approaches influenced society and penetrated into general communication.

One of the works of that period is an essay by H. Spencer "Philosophy of Style", published in 1852 (Spencer, 2009). It implemented the approach of natural science in humanities. The essay also demonstrates new "practical rhetoric" and new ways of "better" intellectual communication. It does not mean that the essay must be taken as absolute and eternal truth. It is one of the approaches, deviating the standards of Anglo-Saxon intellectual style and writing traditions in tote. Some of its statements will be considered later.

\section{3 "The Philosophy of Style" by H. Spencer. Some of the Main Statements}

\subsection{Preliminary Remarks}

I will focus on some techniques proposed by H. Spencer. The essay consists of two parts "Causes of Force in Language Which Depend Upon Economy of the Mental Energies"and "Causes of Force in Language Which Depend Upon Economy of the Mental Sensibilities" representing the cornerstones of the conception. Spencer sees the final goal of the theory in "economizing the reader's or hearer's attention, to so present ideas that they may be apprehended with the least possible mental effort" (Spencer, 2009, p. 3). Language is considered "as an apparatus of symbols for the conveyance of thought" (Spencer, 2009, p. 3) The effectiveness of such apparatus is "the more simple and the better arranged its parts, the greater will be the effect produced" (Spencer, 2009, p. 3). As the result several "innovations" are introduced.

Whether the suggested "new standards" meet the challenges of "economy of mental energies" and "mental sensibilities" is an open question for discussion. Further on, some of the "innovations" are considered. 


\subsection{Vocabulary}

The "first principle" is "if it be an advantage to express an idea in the smallest number of words, then will it be an advantage to express it in the smallest number of syllables" (Spencer, 2009, p. 3) .

\subsubsection{Length of Words}

The words must be short: the less syllables - the better. Hence, the best words to use are the words of Anglo-Saxon origin. A person is familiar to them; they are part of his everyday life. Such words, when in the text, make the comprehension easier. The use of long words of Latin origin makes any text sophisticated. But in some cases words of Latin origin are better if they are more impressive.

Examples: magnificent is stronger than grand; vast is not as expressive as stupendous; disgusting is more emotional than nasty (Spencer, 2009, p. 4).

\subsubsection{Onomatopoeia}

To make the text emotional and to shorten the distance between an author and an addressee it is better to use words imitating some sounds associated with certain situations or circumstances.

Examples: splash, bang, roar, crag (onomatopoeic).

\subsection{3 "Special Words"}

It is better to use so-called "special words". Special words does not mean terms. Any word renders not only meaning but a bunch of required associations. The official, standardized style is not easy for comprehension as it is artificial abstraction. The person will need more efforts to recognize the essence of the abstract idea. The idea is illustrated by the example with two sentences containing the same information message tagged as "bad" and "good" style sentences.

"Bad" style: In proportion as the manners, customs, and amusements of a nation are cruel and barbarous, the regulations of their penal code will be severe. 
"Good" style: In proportion as men delight in battles, bull-fights, and combats of gladiators, will they punish by hanging, burning, and the rack (Spencer, 2009, p. 4).

"Bad" style is neutral and abstract. "Good" style contains imbedded images reconstructing colourful and vivid pictures. Moreover, as the example demonstrates, that abstract phrase needs additional knowledge to interprete it properly, as one has to know what the penal code means. The phrase is replaced in "good" style by concrete types of punishment hanging, burning, the rack. At the same time to understand everything quickly and to imagine the real threat of all these kinds of punishment an addressee must have cultural awareness of these types of punishment.

\subsection{Sentence Level}

English sentence has a fixed word order. Spencer's idea is to create the atmosphere of suspension. It can be achieved if all the words in the sentence will be placed before the subject. Such word order involves a reader step-by-step in the narration. Then when the subject occurs in the very end all the details will be known. The "picture" will be finished by the last brush stroke. "Picture" is considered to be a mental unit by which people obtain information. Spencer illustrates his ideas introducing two examples containing two variants:

A) "Whatever it may be in theory, it is clear that in practice the French idea of liberty

is — the right of every man to be master of the rest."

B) "The French idea of liberty is- the right of every man to be master of the rest; in practice at least, if not in theory" (Spencer, 2009, p. 7).

The second variant (B) is worse for understanding according to $\mathrm{H}$. Spencer.

(2) A) "How immense would be the stimulus to progress, were the bonour now given to wealth and title given exclusively to high achievements and intrinsic worth!"

B) "Were the honour now given to wealth and title given exclusively to high achievements and intrinsic worth, how immense would be the stimulus to progress!" (Spencer, 2009, p. 7) 
In this case the second sentence (B)is preferable as it demonstrates the gradual involvement into the context.

H. Spencer also invented the notions of direct and indirect style.

By given examples H. Spencer insists that for most people the phrases "Water, give me", "The men, they were there" "The king, his crown" with indirect style is the natural mode and employed by "common people", or people with "undisciplined minds" (Spencer, 2009, p. 10). The information message is compressed and involves all association ties required for its proper interpretation. In this case comprehension, interpretation and the feedback, i.e. person's reaction, comes faster.

\subsection{The General Organization of the Text}

H. Spencer focuses on the functional impact the text may have. Stylistics and distribution of stylistic means within a text are important as a tool off text organization.

\subsubsection{Moderate Activity}

Moderate activity assumes to avoid exhaustion. The best way to explain it is done by Spencer: "If we hold a flower to the nose for long, we become insensible to its scent. We say of a very brilliant flash of lightning that it blinds us; which means that our eyes have for a time lost their ability to appreciate light. After eating a quantity of honey, we are apt to think our tea is without sugar" (Spencer, 2009, p. 17). Exhaustion concerns everything. Even a good and effective for comprehension text, in his opinion, is boring and soon will become hard to understand if it contains redundancy. Redundancy concerns stylistic figures, rhetorical means, and "forceful" words.

\subsubsection{Variety as the Means for Text Simplification}

Even the most expressive speech may lose its effectiveness when "constantly employing forcible forms of expression: and it points out that as the easiest posture by and by becomes fatiguing" (Spencer, 2009, p. 19). The result the attention is lost. He wrote: "We must subordinate the component effect to the total effect" (Spencer, 2009, p. 19). Variety assumes the mixture of words from various styles and registers, sentences with "direct" and "indirect" word order, 
pathetic fragments with informal parts. Such mixture will not let a reader/listener adapt to a text, lose attention. Neutrality may cause the effect of constant flow dissipating one's focus, leading to content neglecting.

It is interesting to mention that all the "innovations" listed above were suggested to be applied not only to English language but to other languages.

\section{Modern Academic Communication within the Framework of $\mathbf{H}$. Spencer's Ideas}

Nowadays there is the necessity for fast knowledge dissemination. Hence the problem of effective knowledge delivery is challenging. Some of the techniques considered above found its way in modern communication by means of new reality: network technologies. Taking into account the established standards of professional communication, the techniques can be used in part where deviations are possible. The spheres of their applications are:

- some means are used nowadays mostly in oral presentations or lectures;

- in communication through the Internet: blogs, forums, internet articles (a special genre of professional communication).

Network professional communication forms the largest part of knowledge dissemination nowadays. People from different countries, i.e. cultures, are involved in such type of information exchange which is mostly in English.

One of the examples is the article published in one of the blogs. The author is Marilyn Booth,the article was posted on March 6, 2015; the title "Discussing science in a digital age" (https://beisdigital.blog.gov.uk/2015/03/06/discussing-science-in-a-digitalage/).The article is based on the research of oral discussions, blogs, online conversations. The final conclusion - science must be comprehensible, and explicit to a wide range of people as the main part of participators are "preengaged who already hold strong views". The most fascinating thing is the language of this article following some techniques suggested by H. Spencer. 


\subsection{Vocabulary}

The preference toAnglo-Saxon words, or short words.

(1) ... science is usually used to shore up ethical or political arguments, rather than to inform, or present a balanced picture of all the research on an issue.

(2) ...Many of the debates boiled down to discussions of scientific authority ...

(3) ...to grab people's attention ...

There are certain words used in a transferred meaning which evoke certain concrete images.

Examples. (1) The research from these surveys, which has been published regularly since 2000, informs BIS's Science and Society activities and policies and is also used by our stakeholders, such as the British Science Association, Engineering UK and the Royal Society. (Economics) (2)...competitive tender (Economics)

(3) $\quad .$. to develop a toolkit for science communicators who want to engage online ... (Technical sphere)

Similar examples can be found in other Internet sources.

(4) Implications - social media tips and tricks for science communicators (the subtitle)

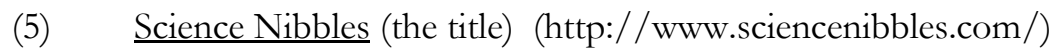

There are some terms containing metaphorical meaning. They name particular phenomena in the field of Computer Science.

(1) Cookies - small data files placed on computer

(2) Smart point-icon containing instructions for help

\subsection{Sentence Structure, Complex Sentence}

In Internet sources there can be found a mix of so-called "direct" and "indirect style". The prevailing one is "direct style". The use of "indirect style" imitates informal communication, psychologically reducing the distance between "scientist with a status" and so-called "young scientist".

(1) Since it is so light, durable, and cheap, there is possibility that it can make bigh resolution images available anywhere in the world. It could also be used as an educational aid.( http://www.sciencenibbles.com/) - Indirect 
(2) Because the practice of science encourages dialogue, requires diverse perspectives, and has no political agenda, we hope this Teach-Out is a useful step in encouraging more science conversations between individuals and their local, national, and global communities. (https://www.class-central.com/course/edx-stand-up-for-science-practicalapproaches-to-discussing-science-that-matters-8262) - Indirect

On Being a Scientist will provide you with an overview of scientific practice, what it means to be a scientist and allows you to become acquainted with academic conduct, thus meeting a demand for increased awareness in scientific integrity. (https://www.classcentral.com/course/coursera-on-being-a-scientist-9969) - Indirect

(4) After discussing the different viewpoints, have students design an investigation, individually or in groups, to see who is correct using the Storyboard ... (https://www.storyboardthat.com/articles/e/science-discussions) Indirect

\subsection{Text organization. The Use of Variation of Styles}

Variation of styles is a widely used method to make information exchange effective and easy. The changes of style work as switches helping to catch and keep the addressee's attention. One of the examples is the article already mentioned above. Here the longer fragment of the article is given.

Example: Remember that trust is often low. In scientific debates, it tends to be attached to institutions and posts rather than people....

Traditional media is your friend! Much of the online conversation consists of links back to trusted sources; the BBC and the traditional newspapers in particular for science conversations, ...

Don't just preach to the converted! Many interventions into the online science conversation are unlikely to reach those who are uninterested or on the 'other side' of the debate unless you actively and directly engage them....

Science alone isn't enough. You need to grab people's attention and make your story 'shareable'. What can you do to make what you're saying more visually interesting, more humorous or more relevant to people's daily lives? (Booth, 2015)

The example demonstrates that each paragraph begins with a sentence highlighting the main statement. The author uses imperative mood, exclamation 
sentences, and questions to subdivide the text into meaningful parts with the same idea. The opening sentence is given in informal style contrasting with the further narration.

\section{$5 \quad$ Conclusion and Discussion}

Although the methods and techniques considered and demonstrated above can be applied to any language and not only to professional texts, their implementation is highly discussible. Some ideas will be really effective in information delivery, others, such as word order rather discussible. They sometimes do not facilitate text but, quite the opposite, make it less comprehensible. The main question - whether they simplify professional communication or make it more complicated - is still open. Another open question is - what should academic discussion and communication be to achieve its main goal: to obtain knowledge? As the examples from Internet sources have shown some informal inclusions make the text effective for understanding. So, one more question occurs: whether to follow traditional academic approach or to take into account the tendency emerged within the Internet and reflected in the titles (taken from the Internet)?

Example: Discussing science over a steaming cup of coffee.

Discussing science with a pint.

The problem is worth being discussed.

\section{References}

Bazerman, C. (1988). Shaping written knowledge: The genre and activity of the experimental article in science. USA: University of Wisconsin Press.

Booth, M. (2015). Discussing science in a digital age. Retrieved September 12, 2018, from https://beisdigital.blog.gov.uk/2015/03/06/discussing-science-in-a-digitalage/)

Clyne, M. (1981). Culture and discourse structure. Journal of Pragmatics, 5, 61-66.

Clyne, M. (1987).Cultural differences in the organization of academic texts. Journal of Pragmatics 11, 211-247.

Duszak, A. (1994). Academic discourse and intellectual styles. Journal of Pragmatics, 21, 291-313.

Grice, H. P. (1975). Logic and Conversation. In P. Cole, \& J. L. Morgan. (Eds.), Syntax and semantics, Vol. 3, Speech Acts (pp. 41-58). New York: Academic Press. 
Lesiak-Bielawska, E. D. (2015). English for specific purposes in historical perspective. English for specific purposes world, 19. Retrieved May 17, 2018, from www.espworld.info

Mauranen, A., Hynninen, N., \& Ranta, E. (2016). English as the academic lingua franca. In K. Hyland \& P. Shaw (Eds.), The Routledge Handbook of English for Academic Purposes (pp. 44-55). Abingdon: Routledge.

Spencer, H. (2009). The Philosophy of Style. Retrieved from http:/ /www.gutenberg.org/ files/5849/5849-h/5849-h.htm

Wood, A. (2001). International scientific English: The language of research scientists around the world. In J. Flowerdew, \& M. Peacock (Eds.), Research perspectives on English for academic purposes (pp.71-83). Cambridge: Cambridge University Press.

Zappen, J. R. (1991). Scientific rhetoric in the nineteenth and early twentieth centuries. In C. Bazerman\& J. Paradis (Eds.), Textual dynamics of the Professions (pp. 145-167). Madison: University of Wisconsin Press. 


\title{
Fears and Anxieties of University Students in Learning English for Professional Purposes
}

\author{
Dubravka Pleše, Tina MiholjanČAn \& Ines JelovČIĆ
}

\begin{abstract}
Lately, several Faculties within the scope of the University of Zagreb (4) chose to suspend English classes, believing them to be superfluous since, as the common wisdom states, everyone speaks English today. However, it has become obvious that many students have struggled with learning English during their secondary education and haven't obtained the desired level of proficiency necessary for reading professional literature, fundamental for their studies. Students' views and attitudes towards any language (including English) may reveal a lot about issues and problems they might be facing as well as their reasons for learning a language. By means of a survey, in this paper we have tried to examine the attitudes of students of the University of Zagreb's Faculty of Mining, Geology and Petroleum Engineering (RGN) and students of the Faculty of Humanities and Social Sciences (HUM), towards learning professional English as well as their fears and anxieties connected to foreign language learning.
\end{abstract}

Keywords: $\bullet$ ESP $\bullet$ attitudes $\bullet$ fears $\bullet$ anxieties $\bullet$ students $\bullet$

CORReSPONDENCE AdDress: Dubravka Pleše, PhD, Senior Lecturer, University of Zagreb, Faculty of Mining, Geology and Petroleum Engineering, Pierottijeva 6, 10000 Zagreb, Croatia, email: dubravka.plese@gmail.com. Tina Miholjančan, B.A. in English and German, Senior Lecturer, University of Zagreb, Faculty of Humanities and Social Sciences, Ivana Lučića 3, 10000 Zagreb, Croatia, e-mail: tina.miholjancan@ffzg.hr. Ines Jelovčić, MSc, Senior Lecturer, University of Zagreb, Faculty of Humanities and Social Sciences, Ivana Lučića 3, 10000 Zagreb, Croatia, e-mail: ijelovci@ffzg.hr. 


\section{$1 \quad$ Introduction}

In the words of Jasone Cenoz and Ulrike Jessner (2000, p. 5), English has become "the lingua franca for trade, tourism, air travel, popular media, sport, science, technology and many other fields of importance in contemporary life" and is also "a sine qua non if one wants to gain access to international electronic information networks". As is the case in many countries in Europe and, indeed, around the world, English is the leading foreign language in Croatia. Although, historically speaking, a large part of continental Croatia used to speak German as its second language (coastal areas used Italian), in the past 30-40 years English has taken over and today it is the most widely taught foreign language at all levels of the educational system. Some 40 years ago, children used to begin learning a foreign language at schools at the age of 10 or 11 years old (4th grade) but, approximately 20 years ago Croatia adopted the early language learning system and English started being taught from the first grade of elementary school onwards (from the age of 6 or 7 years old). Many children in Croatia start even earlier, during preschool. They are constantly surrounded by English, from music, films, TV programmes, YouTube channels. Croatian students also have many opportunities to use English outside the classroom - Croatia is a tourismoriented country. However, by the time some children reach high school, problems start to appear.

As language teachers at two of the University of Zagreb's faculties, we decided to investigate the problems some of our students faced in their studies of English at the tertiary level. The questions that the survey and the article will try to answer are the following: Do our students feel anxious when forced to use the English language? What are some of the most frequently encountered problems connected to language learning? How can we help them develop greater proficiency? For that purpose, we devised a survey and questioned 128 participants at each Faculty. The results of the survey will be presented in this article.

The hypothesis was that the students of the Faculty of Humanities and Social Sciences will experience far fewer anxieties connected to language learning and production and be better at dealing with them, since their fields of study also fall in the categories of Social sciences (much closer to language study), than the 
students of the Faculty of Mining, Geology or Petroleum Engineering, who are a more technically minded and less communicative group.

\section{$2 \quad$ Method}

The data was collected through a two-part questionnaire. The first part of the questionnaire required personal information such as gender, their current age, the age when the students started to learn English, their most frequent grade and the most frequent grade they had in elementary and high school. However, only the students' gender was deemed relevant for our survey since they are all of more or less the same age and since the majority started learning English very early on, between the ages of 5 and 7. The grades achieved during their previous education didn't seem to be relevant for this particular investigation since they were based on their knowledge of general English and not professional English, which is what we teach.

The second part of the questionnaire consisted of a list of seven qualities of English, based on the five-point Likert scale, a closed-ended item format (Dörnyei \& Csizér, 2012, p. 76), which does not require the respondents to produce any free writing. The statements were as follows: 1) English is a complicated language; 2) English grammar is difficult; 3) I feel uncomfortable and I don't have enough confidence when I communicate in English; 4) I wish I could speak English fluently; 5) I don't like to communicate in English because of my accent; 6) I would like to speak as close to the native speakers of English as possible and 7) I have problems with writing in English.

Each of these statements was to be ranked on a scale from 1 to 5, 1 meaning 'completely disagree', and 5 meaning 'strongly agree'.

To avoid the discomfort of students and possible misunderstandings due to the different levels of students' competence in English, the questionnaire was presented in Croatian. 


\section{$3 \quad$ Participants}

The sample included 256 first year students, 128 at the Faculty of Mining, Geology and Petroleum Engineering and 128 at the Faculty of Humanities and Social Sciences. As the figure below shows, at the Faculty of Mining, Geology and Petroleum Engineering 76 of them were male students, making $59.37 \%$ of the group, and 52 were female, making $40.63 \%$ of the group. The distribution at the Faculty of Humanities and Social Sciences was somewhat different, with only 20 male students making $15.62 \%$ of the group and 108 female students making $84.38 \%$ of the group.

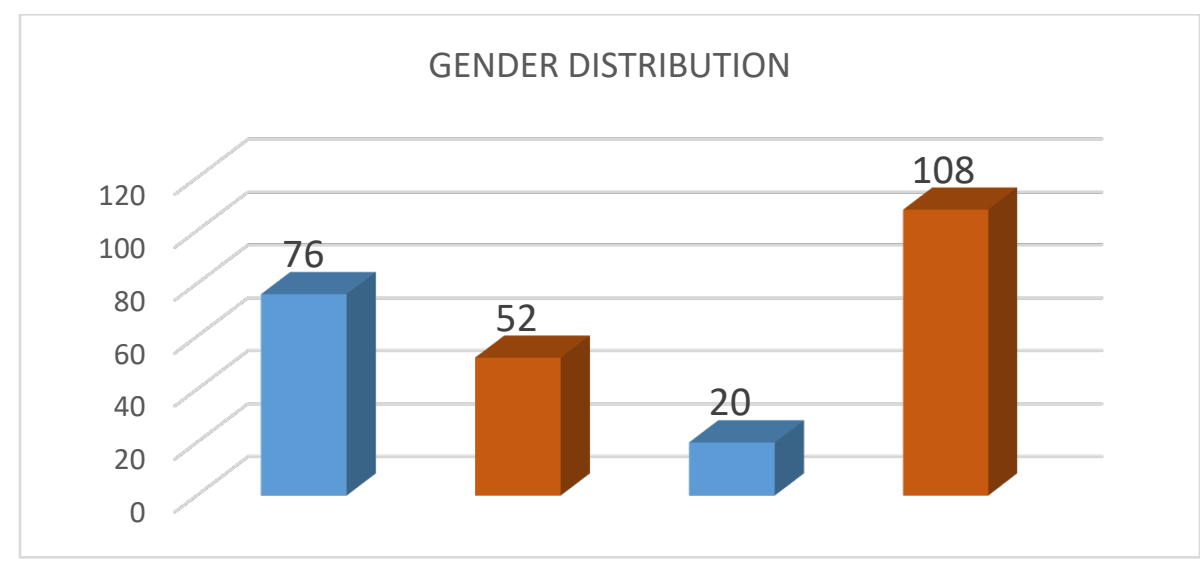

Figure 1: Table showing gender distribution

Since our questionnaire was based on a five-point Likert scale, the answers are presented in the same manner, i.e. ranging from 1-5, 1 being "I don't agree at all" and 5 meaning "I fully agree". All other numbers follow the scale of ever-growing stronger agreement.

More students of the Faculty of Mining, Geology and Petroleum Engineering (2.7) consider English to be a complicated language to learn and master, than the students of the Faculty of Humanities and Social Sciences (2.34), as is seen from Figure 2 . 
However, the small difference came as a surprise since we expected Petroleum Engineering, Mining and Geology students to be far less oriented towards humanities and social sciences (and, of course, languages). We expected such subject matter to be far more difficult for them to cover than for students whose principal field of interest are Humanities and Socials Sciences.

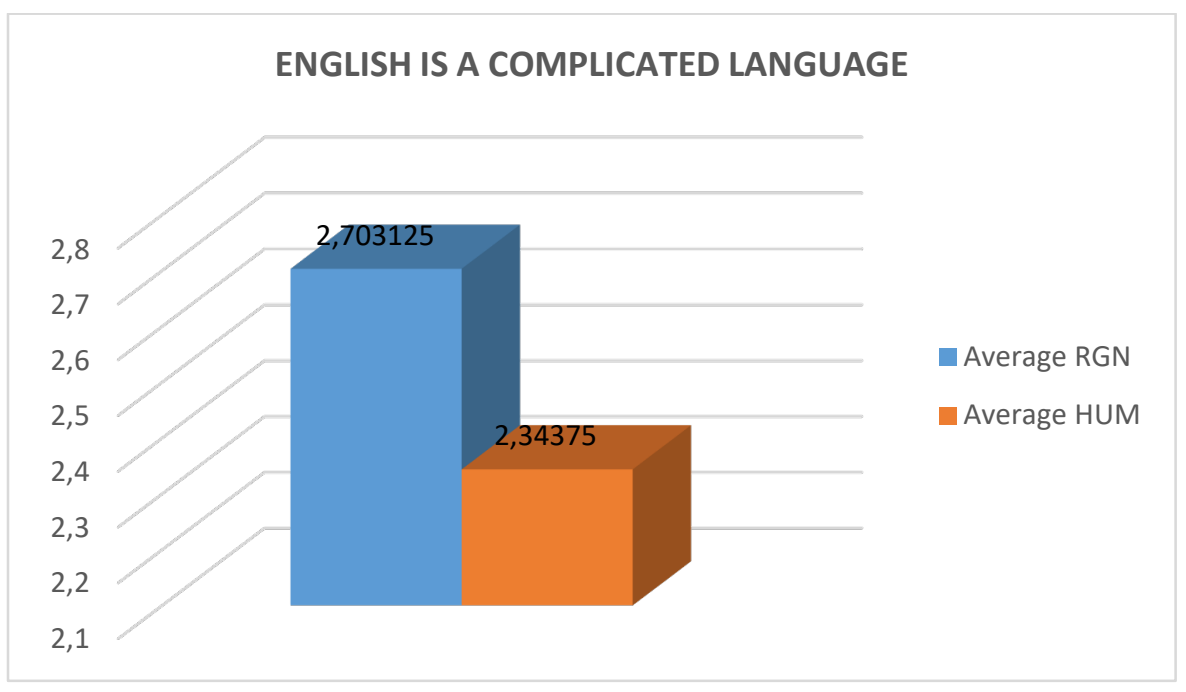

Figure 2: English is a complicated language

On average, students of the Faculty of Mining, Geology and Petroleum Engineering graded the question of the difficulty of English grammar 2.64 while the students of the Faculty of Humanities and Social Sciences followed closely behind, grading this question 2.51. Although the difficulty level seems to be somewhat higher for the engineering students, the Humanities students also do not consider English grammar to be easily understood and simple to use. 


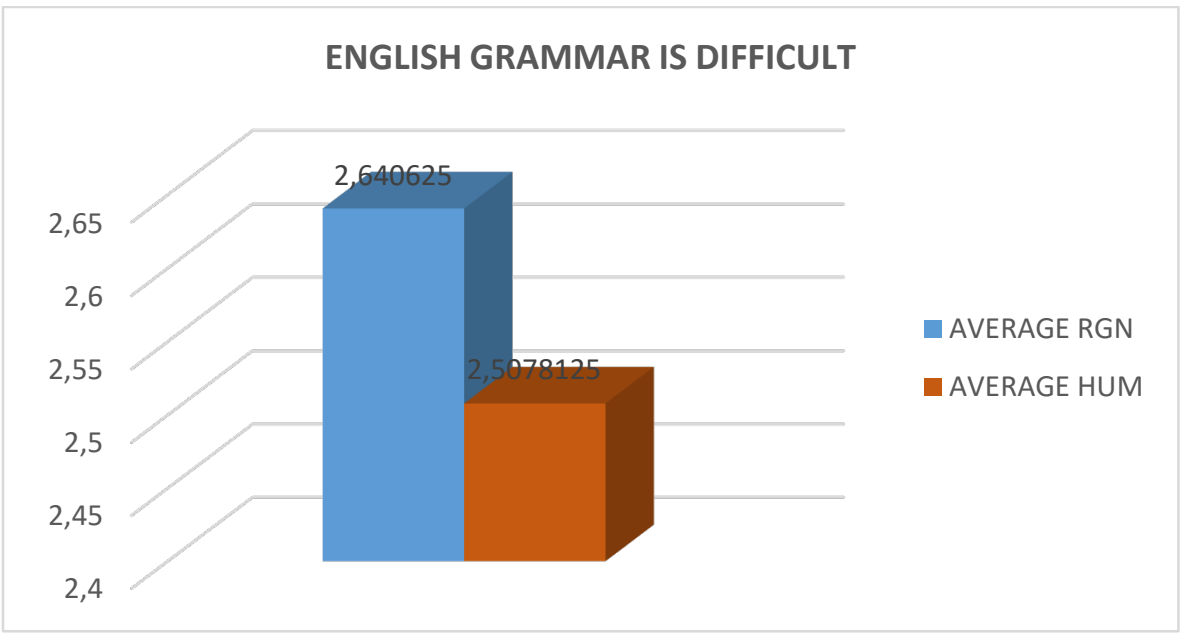

Figure 3: English grammar is difficult

The lack of comfort and confidence when speaking English is a sore spot for all learners of foreign languages, so we were not surprised to get similar answers from students of both Faculties (Engineering students 2.51 and Humanities students 2.45). Students generally find it hard to start speaking unless they are certain that they will be able to produce correct sentences. The fears are connected to their perceptions of their own language abilities as well as the opinions of their colleagues and their reaction to any and all mistakes made by the speaker. This may prove to be a serious problem since discomfort, shame and fear can reduce students' interest in language learning and improving their proficiency. In extreme cases, it can also result in a negative attitude towards a language. However, the teacher can do a great deal to alleviate the students' language anxiety. In the words of Horwitz, Horwitz and Cope (1986, p. 131): "teachers should always consider the possibility that anxiety is responsible for the student behaviour (...) before attributing poor student performance solely to the lack of ability, inadequate background, or poor motivation". 


\section{FEEL UNCONFORTABLE AND I DON'T HAVE ENOUGH CONFIDENCE WHEN I COMMUNICATE IN ENGLISH}

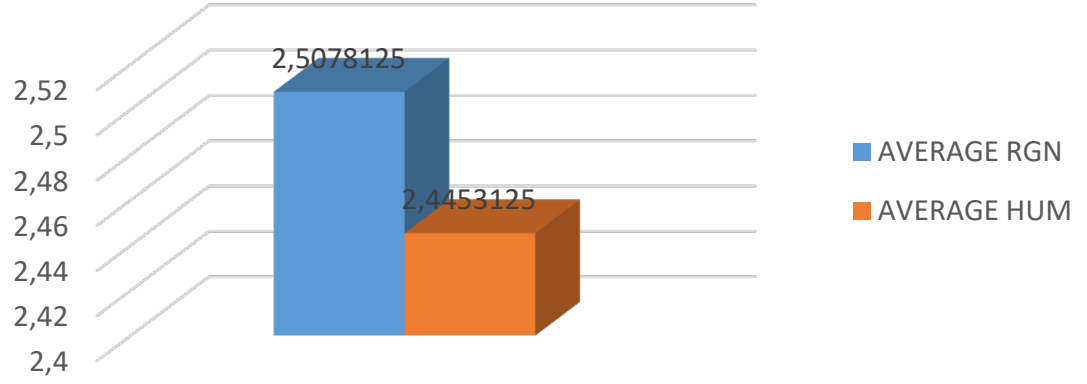

Figure 4: I feel uncomfortable and I don't have enough confidence when I communicate in English

Fluency is greatly desired by students of both Faculties, which is clearly seen by the results of the survey and presented by Figure 5. However, this is a very difficult goal to achieve since it is reached by practice, speaking, ad general good command of English structures and vocabulary. Our students come to us as fully formed individuals, with some 12 years of study of English under their belts and it would be unrealistic to expect us to transform their lack of knowledge and confidence within just one or two semesters. If it were possible for our students to continue their studies in English or in an English-speaking environment, that would, without a doubt, improve their fluency and alleviate their fears of speaking English. Another reason why fluency seems to be the greatest problem is probably the widespread belief that the only way to speak a foreign language is to speak it perfectly, absolutely correctly, or not at all. Such beliefs are a source of great anxiety to students because they are completely unrealistic since even the best students (and, by all means, teachers and other language professionals) occasionally make mistakes, forget or have to guess the meaning of the words. This anxiety is further exacerbated by the constant production monitoring and correction as well as evaluation to which production is closely connected and that takes place during the class. As Horwitz, Horwitz and Cope (1986, p. 131) say: "Scholars are only beginning to understand the role of anxiety in foreign language learning; we do not yet know how pervasive foreign language anxiety is nor do we comprehend its precise repercussions in the classroom. We do know that individual reactions can vary widely." 


\section{WISH I COULD SPEAK ENGLISH FLUENTLY}

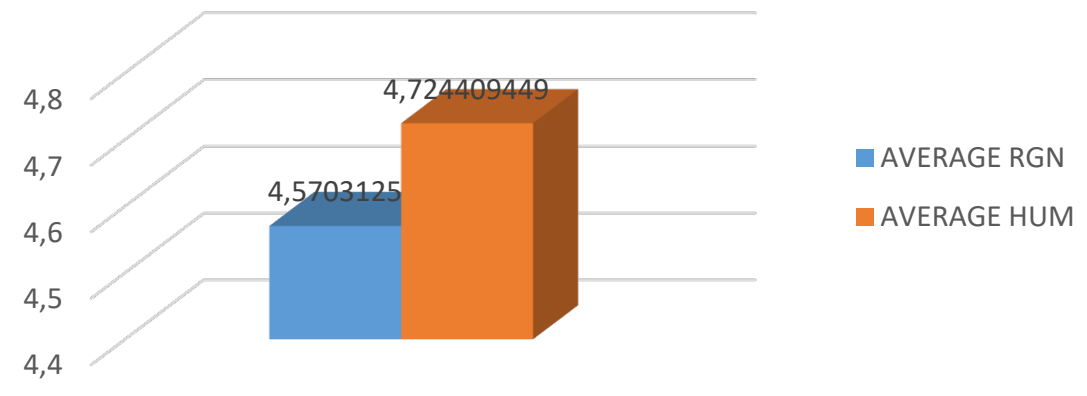

Figure 5: I wish I could speak English fluently

The question of accent (see Figure 5) is present in all language learners since that is the one thing that cannot be hidden or learned away. Our native tongue, its pronunciation and phonetic structure, define us all and only a lucky few will ever be able to mask the accent. However, common sense says that the earlier the children begin to learn the language, the less their accent. Still, in our opinion, this greatly depends on the teacher, their pronunciation and accent, as well as the student's "ear", and the willingness to mimic the good example. Still it seems that our students are well aware of all of the things mentioned and that their audible accents do not represent a great source of distress or cause anxiety.

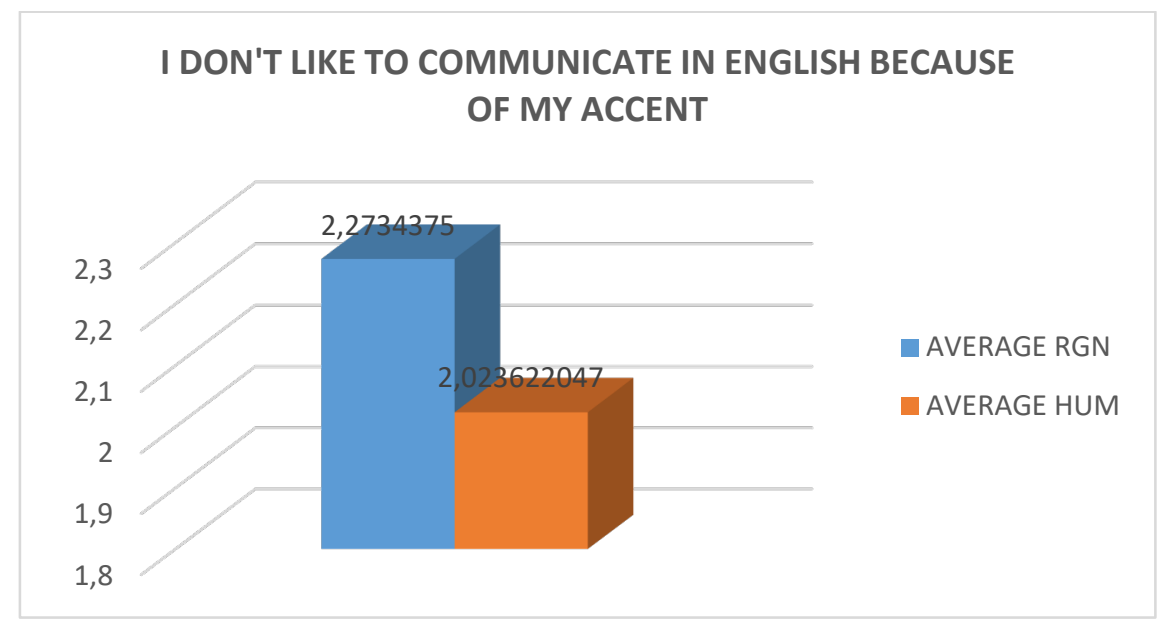

Figure 6: I don't like to communicate in English because of my accent 
The students' desire to match the speech of native speakers seems to be more of a goal for the students of the Faculty of Humanities and Social Sciences than for the students of the Faculty of Mining, Geology and Petroleum Engineering. The reason is probably the fact that students of the Faculty of Humanities and Social Sciences are more oriented by their chosen professions towards oral communication than are Engineering students, who mainly work with machines and numbers and don't communicate orally with others a great deal.

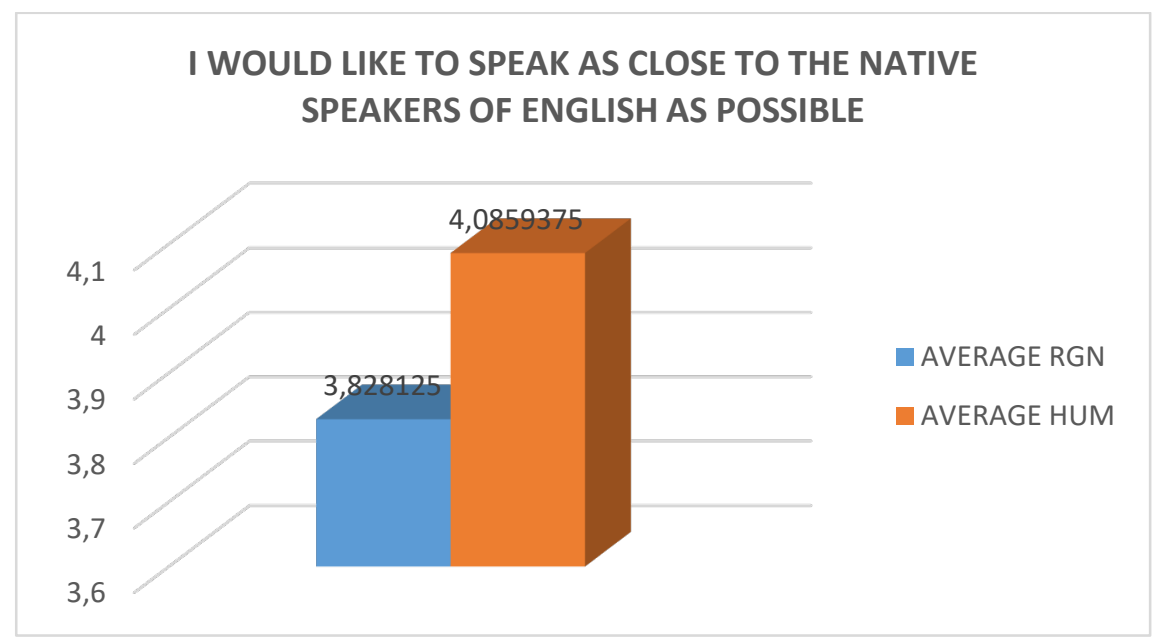

Figure 7: I would like to speak as close to the native speakers of English as possible.

Surprisingly, students of both Faculties do not perceive themselves as having a great deal of problems with writing (see Figure 8), which is not corroborated by the results of their written exams. One possible explanation of this is that they rely greatly on the autocorrect function of their computers, hoping that their mistakes will be corrected by the system or, perhaps, they expect their writing to be corrected by a professional before the text is published. In either case, writing does not seem to be a great source of anxiety and does not seem to greatly impact the motivation of our students. 


\section{HAVE PROBLEMS WITH WRITING IN ENGLISH}

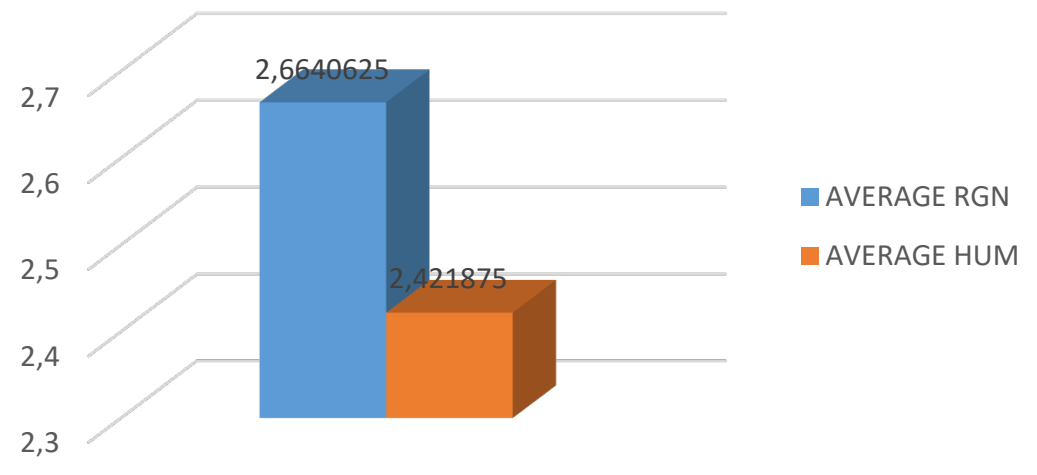

Figure 8: I have problems with writing in English.

\section{5}

\section{Discussion}

The results of our survey came as a surprise to us since it was not expected for margins to be so small. Both groups of students agree that English is a complicated language with difficult grammar and both groups are unsure of themselves when the time comes to use the language for communication. Both groups express a great desire to speak English more fluently and to improve their accents. However, neither group pays special attention to the existing issues with writing and does not view the problems related to writing as a serious hindrance or source of anxiety. The only point where there is a greater difference between the two groups is their wish to speak English as well as native speakers (or as closely to that as possible). The students of the Faculty of Humanities and Social Sciences are more aware and more troubled by the fact that their production is not perfect than are the Students of the Faculty of Mining, Geology and Petroleum Engineering.

\section{Conclusion}

After reviewing the results of the survey, we came to the following conclusions. As teachers of English at the tertiary level, it is our duty to accept the fact that language learning anxiety will always be present in a certain percentage of our students. It is therefore our duty to try and help our students to manage their 
existing language learning anxiety and to reduce the level of stress in our learning/teaching environments. We should not be quick to judge that the apparent lack of knowledge or motivation in our students is connected to their lack of ability or desire to learn but accept that stress and anxiety may play a significant role in their overall achievement. Our students consider the subject we teach to be important and we should focus on helping them achieve their goals. We should also strive to create positive language attitudes since they correlate with learners' positive orientation towards learning English.

\section{References}

Cenoz, J., \& Jessner, U. (2000). English in Europe: The acquisition of a third language. Multilingual Matters.

Dörnyei, Z., \& Csizér, K. (2012). How to design and analyze surveys in second language acquisition research. In A. Mackey \& S. M. Gass (Eds.), Research methods in second language acquisition: A practical guide, (pp. 75-95). Oxford: Blackwell.

Horwitz, E. K., Horwitz, M. B., \& Cope, J. (1986). Foreign language classroom anxiety. The Modern Language Journal, 70(2), 125-132. 


\title{
The Effects of Project Presentation before a Professional Committee on Student Motivation
}

\author{
Martina Pokupec, Dijana NJerš \& Milan Papić
}

\begin{abstract}
Project-based learning has been widely accepted and implemented as one of the highly effective teaching and learning methods. In foreign language acquisition, PBL provides grounds for integrating language skills development with specific content knowledge, whereby students engage in vocabulary skills development, comprehension development, written and oral communication skills development alongside exploring in depth the specific area of study they have chosen as their professional careers. The final element of PBL is presentation of the project not only before a teacher, but before a team of professionals within the specific area of study, i.e. public product. The goal of this paper was to test to what extent this aspect affects student motivation and anxiety levels during project development and presentation. We implemented PBL with 2nd and 3rd year students of Tourism and Hospitality Management, separated into two groups: one group made their presentation before a professional committee and the other before their teacher and classmates only, and we compared student motivation and anxiety levels between the two groups.
\end{abstract}

Keywords: • project-based learning • English for Specific Purposes - teaching methodology $\bullet$ student motivation $\bullet$ student anxiety $\bullet$

CORRESPONDENCE ADDRESS: Martina Pokupec, MEd, lecturer, Libertas International University, Zagreb, Trg. J. F. Kennedyja 6b, Croatia, e-mail: martinapokupec@gmail.com. Dijana Njerš, Professor, Senior Lecturer, University of Zagreb, Faculty of Food Technology and Biotechnology, 6 Pierottijeva street, Zagreb, Croatia, e-mail: dnjers@pbf.hr. Milan Papić, MSc, Senior Lecturer, Libertas International University, Zagreb, Trg. J. F. Kennedyja 6b, Croatia, e-mail: mpapic@libertas.hr. 


\section{$1 \quad$ Introduction}

Project-based learning (PBL) is a task-based, student-centred teaching method through which students engage in various learning activities and research or investigation over an extended period of time in order to provide an answer to an original, authentic and complex question, problem or challenge. The goal of project-based learning is to develop deep content knowledge, critical thinking skills, creativity and communication skills; moreover, it provides students with an opportunity to engage in solving real-world problems closely connected to their own professional choices. "Students drive their own learning through inquiry, as well as work collaboratively to research and create projects that reflect their knowledge" (Bell, 2010, p. 39). The definition of PBL provided by Wurdinger, Haar, Hugg and Bezon (2007, p. 151) is that project-based learning is "a teaching method where teachers guide students through a problem-solving process which includes identifying a problem, developing a plan, testing the plan against reality, and reflecting on the plan while in the process of designing and completing a project". The method exhibits more or less the same learning elements as problem-based learning, with the main difference in that projectbased learning culminates in an original product, whereas problem-based learning is more focused on the process of learning.

The basis of project-based learning is the inquiry, also called a driving question, imposed by students themselves or the teacher, the answer to which needs to be collaboratively investigated by applying and/or acquiring content knowledge, critical thinking and communication skills in order to provide an authentic and original solution or a product. (Kokotsaki, Menzies \& Wiggins, 2016, p. 1). The elements or activities of project-based learning, apart from designing a driving question, are independent student research, collaborative knowledge sharing, decision-making and organisation, critique and revision and public presentation.

While this teaching and learning approach is sensible, logical and easily applicable in courses related to development of professional skills, such as information technology, human resource management, sales or marketing, where students are able to create authentic products or solutions to real problems, PBL is also a highly effective teaching method in foreign language courses, especially courses of language for professional purposes. Projects are also used in primary and secondary school instruction with various sets of goals and purposes (Supe \& 
Kaupuzs, 2015). As the main focus of language instruction is still the development of the four language skills, we can connect all of them to PBL (Mikulec \& Miller, 2011). Students always work in teams when engaged in PBL, their listening and speaking skills are developed during the phases of organising project work, sharing information about their research, providing feedback, critiquing and revising their work, as well as delivering a presentation. In doing independent or group research, students develop their reading and writing skills by investigating the problem through available literature, comparing their ideas with the existing ones, writing summaries about their findings and, depending on the goal of the project producing various types of texts supporting their project work and presentation. We can say that project-based learning integrates various teaching methods, from the communication approach and collaborative learning to task-based learning, keeping the students engaged all the time and in control of their own learning. In English for Specific Purposes, project-based learning is ideal for the integration of specific content and language skills (Alsamani \& DaifAllah, 2016). Students are focused on developing a unique project related to their specific future profession, while the language in which they elaborate and complete their knowledge is the target language, in this case, English.

Also, in order for project-based learning to become an integral part of an ESP course syllabus, it is essential to set language related learning outcomes and language related assessment methods. In other words, if the goal of a project is a marketing campaign for a specific brand, the language teacher assesses only language related production, such as understanding of literature investigated, language of the presentation and written texts etc. regardless of the relevance of the campaign for the brand in question, for example. This may affect student motivation; however, here is where the final project presentation takes effect.

One of the essential elements of project-based learning is public product, which is a tangible product or a presentation of an idea or a solution to a problem, i.e. the answer to the driving question (Larmer \& Mergendoller, 2015). Instead of presenting their project to other students in a classroom and a teacher, students make a public presentation before a group of experts or professionals in the field. This can also go above and beyond the classroom, depending on the project and available resources, so students can present their work in the wider community. 
Since PBL is conceptualised in such a way to provide students with opportunities to actively learn by organising their learning and research in their own way and as best they see, to share their own ideas about how to approach the project and freedom to decide what activities they will engage in in order to answer the driving question, it has been seen more motivating than not for student learning and development of deeper knowledge (Blumenfeld et al., 1991). Making the presentation of a project product public builds upon student motivation by making their work relevant in the real-world and by providing students with an opportunity to not only showcase their work before the relevant public, but also an opportunity to receive feedback from relevant experts in their chosen professional field.

The aim of this paper was to investigate whether the fact of a public project presentation has an effect on student motivation or anxiety in undergraduatelevel students of English for Specific Purposes.

\section{$2 \quad$ Research}

We implemented project-based learning with $2^{\text {nd }}$ year and $3^{\text {rd }}$ year students of the undergraduate professional study programme of Tourism and Hospitality Management at Libertas International University in Zagreb during the last 5 weeks of classes of the summer semester 2018. On the first day of the project half of the teams of each group of students were divided into two groups, one of which would make their presentation before two experts in the tourism and hospitality industry, the other delivered the presentation before classmates and the teacher.

The aim of our research was to investigate whether the students selected to present before a team of experts would be more motivated or more anxious to do the project, with the hypothesis that there would be a difference in the level of student motivation between the two groups. 


\subsection{Methodology}

There was a total of 76 students participating in project-based learning, 28 male students and 48 female students. At the first session, they were divided into two groups, one of which (38) presented their project results before a team of professionals, and the other (38) presented their project results before their classmates and the teacher. The two groups were selected randomly.

In order to test their motivation and anxiety levels, each student was given an anonymous questionnaire immediately after their presentation to reflect on their motivation during the elaboration and presentation of the project.

The statements addressing motivation were:

1. I made more effort to achieve better results during the project then I did in other forms of knowledge assessment.

2. I frequently consulted with my team about my work.

3. My group frequently consulted with the teacher during the elaboration of the project.

4. I was more engaged in order to achieve a successful project than I am in other types of group activities.

5. I dedicated a lot of time to express myself accurately in English.

The statements addressing anxiety were:

1. I felt discomfort during the elaboration and presentation of the project.

2. I felt nervous during the elaboration and presentation of the project.

3. I felt fear during the elaboration and presentation of the project.

4. Discomfort/nervousness/fear prevented me from showcasing my best capabilities during the elaboration and presentation of the project.

5. Due to discomfort/nervousness/fear I expressed myself in English more poorly than I usually do.

The responses to the statements were given in the form of a 5-point Likert scale (I strongly agree -5 , I moderately agree -4 , I neither agree nor disagree -3 , I moderately disagree -2 , I strongly disagree -1 ) 
The basic indicators of descriptive statistics (arithmetic mean, standard deviation and measure of skewness) were calculated for research results and are presented in Tables 1 and 2 and Figures 1 and 2.

Statistical differences between the two groups of respondents were checked by a t-test for independent samples. Computer programmes MS Excel and SPSS were used for statistical analysis.

\section{$2.2 \quad$ Results}

Tables 1 and 2 show results of statistical analysis of the obtained results (arithmetic mean, standard deviation and $\mathrm{p}$-value of the applied t-test for independent samples). The same results are shown in a form of a graph (Figures 1 and 2).

Table 1: The statements addressing motivation (mean, standard deviation, p-value (ttest))

\begin{tabular}{|c|c|c|c|c|c|}
\hline The statements addressing motivation & group $^{1}$ & $\mathrm{~N}$ & $\mathrm{M}$ & $\mathrm{SD}$ & p-value \\
\hline \multirow{2}{*}{$\begin{array}{l}\text { 1. I made more effort to achieve } \\
\text { better results during the project } \\
\text { then I did in other forms of } \\
\text { knowledge assessment. }\end{array}$} & $\bar{I}$ & 38 & 4.00 & 0.96 & \multirow[b]{2}{*}{0.5465} \\
\hline & II & 38 & 3.87 & 0.93 & \\
\hline \multirow{2}{*}{$\begin{array}{l}\text { 2. I frequently consulted with my } \\
\text { team about my work. }\end{array}$} & $\mathrm{I}$ & 38 & 4.49 & 0.96 & \multirow{2}{*}{0.8481} \\
\hline & II & 38 & 4.45 & 0.79 & \\
\hline \multirow{2}{*}{$\begin{array}{l}\text { 3. My group frequently consulted } \\
\text { with the teacher during the } \\
\text { elaboration of the project. }\end{array}$} & $\mathrm{I}$ & 38 & 3.70 & 1.10 & \multirow{2}{*}{0.9751} \\
\hline & II & 38 & 3.71 & 1.06 & \\
\hline \multirow{2}{*}{$\begin{array}{l}\text { 4. I was more engaged in order to } \\
\text { achieve a successful project than I } \\
\text { am in other types of group } \\
\text { activities. }\end{array}$} & $\mathrm{I}$ & 38 & 3.50 & 1.08 & \multirow[b]{2}{*}{0.6614} \\
\hline & II & 38 & 3.61 & 1.00 & \\
\hline \multirow{2}{*}{$\begin{array}{l}\text { 5. I dedicated a lot of time to } \\
\text { express myself accurately in } \\
\text { English. }\end{array}$} & $\mathrm{I}$ & 38 & 3.79 & 1.23 & \multirow{2}{*}{0.4768} \\
\hline & II & 38 & 3.97 & 1.00 & \\
\hline
\end{tabular}

${ }^{1} \mathrm{I}$ - presented their project results before a team of professionals

II - presented their project results before their classmates and the teacher 


\section{The statements addressing motivation $(\mathrm{N}=76)$}

1. I made more effort to achieve better results during the project...

2. I frequently consulted with my team about my work.

3. My group frequently consulted with the teacher during the...

4. I was more engaged in order to achieve a successful project than I...

5. I dedicated a lot of time to express myself accurately in English.

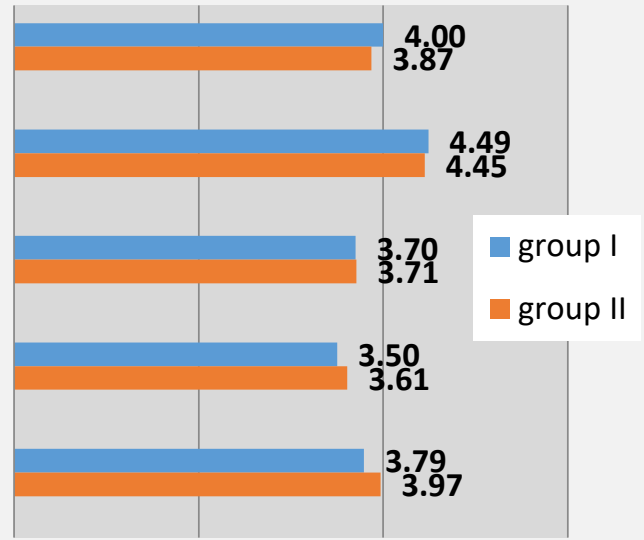

Figure 1: The statements addressing motivation (means)

Table 2: The statements addressing anxiety (mean, standard deviation, p-value (t-test))

\begin{tabular}{|c|c|c|c|c|c|}
\hline The statements addressing anxiety & group $^{2}$ & $\mathrm{~N}$ & $\mathrm{M}$ & SD & $\mathrm{p}$-value \\
\hline \multirow{2}{*}{$\begin{array}{l}\text { 1. I felt discomfort during the } \\
\text { elaboration and presentation of the } \\
\text { project. }\end{array}$} & I & $\begin{array}{l}3 \\
8\end{array}$ & 2.37 & 1.50 & \multirow{2}{*}{0.1440} \\
\hline & II & $\begin{array}{l}3 \\
8\end{array}$ & 2.12 & 1.46 & \\
\hline \multirow{2}{*}{$\begin{array}{l}\text { 2. I felt nervous during the elaboration } \\
\text { and presentation of the project. }\end{array}$} & I & $\begin{array}{l}3 \\
8\end{array}$ & 2.82 & 1.54 & \multirow{2}{*}{0.7683} \\
\hline & II & $\begin{array}{l}3 \\
8\end{array}$ & 2.92 & 1.48 & \\
\hline \multirow{2}{*}{$\begin{array}{l}\text { 3. I felt fear during the elaboration and } \\
\text { presentation of the project. }\end{array}$} & I & $\begin{array}{l}3 \\
8\end{array}$ & 2.39 & 1.37 & \multirow{2}{*}{0.9079} \\
\hline & II & $\begin{array}{l}3 \\
8\end{array}$ & 2.43 & 1.44 & \\
\hline \multirow{2}{*}{$\begin{array}{l}\text { 4. Discomfort/nervousness/ fear } \\
\text { prevented me from showcasing my best } \\
\text { capabilities during the elaboration and } \\
\text { presentation of the project. }\end{array}$} & I & $\begin{array}{l}3 \\
8\end{array}$ & 2.66 & 1.60 & \multirow{2}{*}{0.5079} \\
\hline & II & $\begin{array}{l}3 \\
8 \\
\end{array}$ & 2.89 & 1.50 & \\
\hline \multirow{2}{*}{$\begin{array}{l}\text { 5. Due to discomfort/nervousness/fear } \\
\text { I expressed myself in English more } \\
\text { poorly than I usually do. }\end{array}$} & I & $\begin{array}{l}3 \\
8\end{array}$ & 2.53 & 1.45 & \multirow[b]{2}{*}{0.1101} \\
\hline & II & $\begin{array}{l}3 \\
8\end{array}$ & 3.08 & 1.53 & \\
\hline
\end{tabular}

2 I - presented their project results before a team of professionals

II- presented their project results before their classmates and the teacher 


\section{The statements addressing anxiety $(\mathrm{N}=76)$}

1. I felt discomfort during the elaboration and presentation of the project.

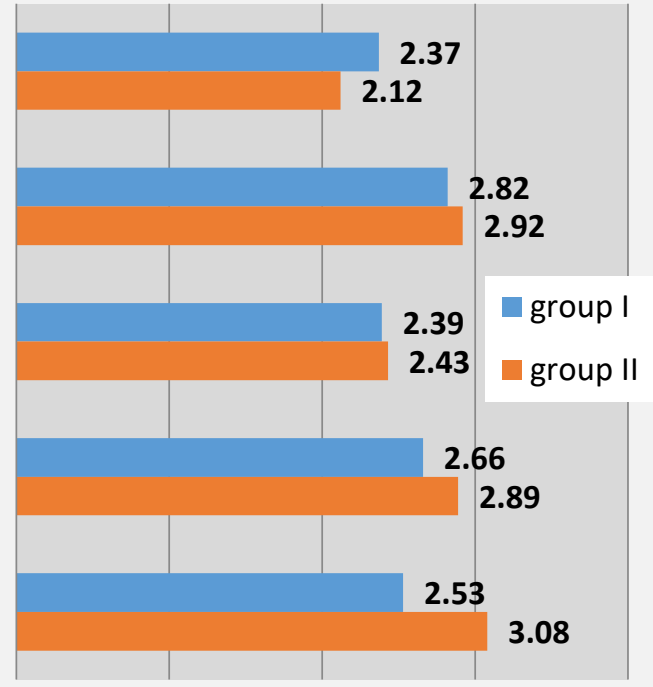

Figure 2: The statements addressing anxiety (means)

The results show that there are no statistically significant differences $(p>0.05)$ in responses to either of the 10 statements between the two observed groups.

The results obtained also show that overall student motivation level (motivation statements $1-5$ ) is higher than anxiety level (anxiety statements $1-5$ ) and that students were most motivated to collaborate with each other (S2), to put more effort into this type of learning activity than any other (S1) and into expressing themselves accurately in the target language (S5). This confirms the statements found in literature and research thus far that project-based learning is a teaching and learning activity that boosts student motivation.

As regards anxiety levels, the students were mostly nervous during project elaboration and presentation (S2) and their levels of anxiety prevented them from showing their best capabilities during project elaboration (S4) and in language output (S5). Although a healthy level of student anxiety works toward higher student outputs, we would like to see these anxiety levels slightly lower, and further research is needed to investigate methods to achieve this. 
Project-based learning is a complex and rewarding teaching and learning activity that, in terms of foreign language acquisition, develops all essential four language skills, but also in terms of the necessary $21^{\text {st }}$ century skills develops critical thinking and problem solving, communication skills, collaboration and teamwork, productivity, initiative and self-direction (Fadel, 2008), which strongly supports the initiative to make PBL central to the curriculum.

In order for this type of teaching and learning activity to achieve its goals, all elements need to be included: challenging problem/question, sustained inquiry, authenticity, student voice and choice, reflection, critique and revision, public product (Larmer \& Mergendoller, 2015). It is also necessary that teachers get proper background and training in implementing PBL, in designing projects and rubrics and in adjusting them to their students and their level of knowledge and skills.

There are many elements of PBL that require further research and elaboration especially with the purpose of clarifying the role of the teacher and that of students during the preparation of the project, of establishing the optimal assessment methods and of the willingness of school management to incorporate PBL as central teaching and learning activity in the programme curriculum and work with the community to provide students with opportunities to present their products and solutions publicly outside their school or classroom.

Our goal was to investigate student feelings about the final PBL element: public product. In order to achieve this, we compared motivation and anxiety levels between two groups of students: those who presented their product before their teacher and classmates, as they would usually do in other types of teaching and learning activities, and those who presented their product publicly before a team of experts in the professional field of their career choices.

Our findings showed no statistically significant difference between the two groups, which may be one of the indicators that transforming classroom teamwork activities into real PBL activities would not affect student anxiety nor prevent them from engaging in this type of learning. Likewise, as the results showed very high levels of student motivation, this type of teaching and learning 
activity engages students to achieve much better results than in other types of activities.

Our research is only a prelude to an extent to which PBL can be implemented and further investigated with the purpose of demonstrating how effective it can be in implementing teaching and learning English as a Foreign Language and English for Specific Purposes. We highly recommend this teaching method to be used with students, and we hope more research into the effectiveness of PBL in an ESP classroom will be published.

\section{References}

Alsamani, A. S. \& Daif-Allah, A. S. (2016). Introducing project-based instruction in the Saudi ESP classroom: A study in Qassim University. English Language Teaching, 9(1), 51-64.

Bell, S. (2010). Project-based learning for the 21st century: Skills for the future. The Clearing House, 83, 39-43.

Blumenfeld, P. C., Soloway E., Marx, R.W., Krajcik, J.S., Guzdial, M. \& Palincsar, A. (1991). Motivating project-based learning: Sustaining the doing, supporting the learning. Educational Psychologist, $26(3$ \& 4), 369-398.

Fadel, C. (2008). 21st Century Skills: How can you prepare students for the new Global Economy? Retrieved from www.oecd.org

Kokotsaki, D., Menzies, V. \& Wiggins, A. (2016). Project-based learning: A review of the literature. Improving Schools, 19(3), 267-277.

Larmer, J. \& Mergendoller, J. R. (2015). Gold Standard PBL: Essential project Design Elements. Retrieved from https://www.bie.org/blog/gold_standard_pbl_essential_project_design_elemen ts

Mikulec, E. \& Miller, P. C. (2011). Using project-based instruction to meet foreign language standards. The Clearing House, 84, 81-86.

Supe, O. \& Kaupuzs, A. (2015). The effectiveness of project -based learning in the acquisition of English as a foreign language. SOCIETY, INTEGRATION, EDUCATION. Proceedings of the International Scientific Conference, 2, 2010-218.

Wurdinger, S., Haar, J., Hugg, R. \& Bezon, J. (2007). A qualitative study using projectbased learning in a mainstream middle school. Improving Schools, 10(2), 150-161. 


\title{
Hedges and Boosters in University Textbooks
}

\author{
STANKA RADOJČIĆ
}

\begin{abstract}
This paper explores hedging and boosting strategies in university textbooks for three disciplines: geography, physics and linguistics in English and Serbian languages. A comparative analysis of three textbooks in English and three textbooks in Serbian was conducted to establish the frequency of hedges and boosters in various disciplines and in two languages. The analysis reveals a vast repertoire of hedging and boosting strategies used to realize the different commitment and detachment orientations employed in the corpus. Furthermore, it shows considerable differences in the overall distribution of hedges and boosters throughout three disciplines as well as in two languages. The use of hedging and boosting devices in the corpus is mainly related to different rhetorical and educational traditions. Also, the variations are regulated both by general rules of communication and the norms and practices of particular disciplines. The unequal distribution also suggests discipline specific hedging and boosting strategies. The results of the research may further facilitate the teaching of English for Academic Purposes at tertiary level and contribute to a better understanding and use of English as the international language of academic communication.
\end{abstract}

Keywords: - academic communication - boosters EAP • comparative analysis $\bullet$ hedges $\bullet$ university textbooks $\bullet$

CORRESPONDENCE ADDRESS: Stanka Radojičić, Master of Philology, English Language Instructor, University of Novi Sad, Faculty of Sciences, Trg Dositeja Obradovića 3, 21101 Novi Sad, Serbia, e-mail: stanka.radojicic@dgt.uns.ac.rs. 


\section{$1 \quad$ Introduction}

Hedging devices are reducing the strength of the propositions and boosting devices are emphasizing the strength of the proposition (Hyland, 1998). The concept of hedges, which may also be referred to as an authorial detachment, and boosters, referred to as an authorial commitment (Vassileva, 2001), are two interconnected issues which have been gaining importance in academic written communication recently. Along similar lines, they have a purpose of realizing communicative strategies of written academic texts.

Although textbooks are considered the basic components inseparable to students' academic careers and also play an irreplaceable role in their experience of language learning specifically for undergraduate students (Hyland, 2009), university textbooks have been insufficiently researched with regard to metadiscourse markers, primarily hedges and boosters.

This paper explores the frequency of hedges and boosters in university textbooks in English and Serbian languages across three disciplines: linguistics, geography and physics. Hedges and boosters can serve a few purposes in student's comprehension of written text, whether native or non-native. Moreover, hedges and boosters can play an assisting role for the students in processing the information presented in the textbooks, so that they could comprehend the stance of the writer towards the texts, as well as the information included, and finally they could provide a negotiation of the stance and get engaged with the text (Hyland, 2005). Rather few researchers investigated hedging and boosting strategies from a pedagogical point of view, specifically textbooks at the tertiary level. The students expect to find their texts signalled with hedging and boosting devices in an adequate way to lead them to text comprehension and understanding of the intended meaning easily and explicitly, however, it is noticeable that students still have problems finding the written texts to be "interactive" and they think that conversation is the only interactive skill (Hyland, 2005). Therefore, it is necessary to investigate whether the textbooks intended for the students have the full potential of serving the readers' purpose, i.e. include necessary hedges and boosters to guide them into desired comprehension of the text. The roles of hedging and boosting, for instance, are well documented in academic discourse as communicative strategies for conveying reliability and strategically manipulating the strength of commitment or detachment to achieve 
interpersonal goals. Thus, hedges and boosters are among textual strategies which employ linguistic means in academic written discourse for specific communicative purpose, e.g. to invite the readers to get involved into propositional content, and to draw attention to the fact that statements do not just communicate ideas, but also the author's attitude to both the ideas and the readers (Halliday, 1978).

\section{Corpus and Methods}

This paper explores the corpus of six university textbooks, three in English language and three in Serbian language, across three different disciplines: linguistics, geography and physics. The text corpus for this small-scale research consists of 6 university textbooks which are selected from university reference lists for specific undergraduate majors at the University of Novi Sad.

\begin{tabular}{|l|l|l|}
\hline Discipline & English Language & Serbian Language \\
\hline \multirow{5}{*}{ Linguistics } & Aarts, B. (2001). English & Ranko Bugarski (2005) \\
& Syntax and Argumentation, & Jerik, i kultura, Beograd: \\
& Hampshire: Palgrave. & Biblioteka XXI vek. \\
\hline \multirow{5}{*}{ Geography } & Castree, N., Demeritt, D., & Stojanović, V., Pavić, D. \\
& Liverman, D. \& Rhoads & \& Pantelić, M. (2014). \\
& B. (2009). A Companion To & Geografija 乏̌ivotne sredine. \\
& Environmental Geography, & Novi Sad: UNS, \\
& Chichester: Blackwell & Prirodno-matematički \\
& Publishing Ltd. & fakultet. \\
\hline \multirow{5}{*}{ Physics } & Tennyson, J. (2005). & Prodanović, T. (2010). \\
& Astronomical Spectroscopy. & Uvod u spektroskopiju za \\
& London: University & astronome. Novi Sad: \\
& College. & UNS, Prirodno- \\
& & matematički fakultet. \\
\hline
\end{tabular}

Table 1: Textbooks used as the corpus of the study

The disciplines are selected to represent a minor cross-section of natural sciences (physics) and social sciences (linguistics) with the science of geography being partly considered a social science and partly a natural science. The main value of such selection is that it makes available insight into the use of hedges and boosters in both social and natural sciences and in both languages. Each 
discipline is represented with one textbook in English language and one in Serbian language with similar discipline specific topic.

The textbooks were converted into an electronic corpus and searched for the occurrences of target features, the types of hedges and boosters adopted from the list compiled from Hyland (2004) and Varttala (2001). The corpus was searched for specific features using AntConc 3.5.7 2018, a text analysis and concordance programme.

\section{$3 \quad$ Results and Discussion}

\subsection{Overall Distribution}

Having scanned the corpora, all the occurrences of hedges and boosters used in the textbooks were noted down. According to the analysis the results for the incidence of hedges and boosters in both English language and Serbian language parts of the corpus are given in the tables below.

\begin{tabular}{|l|c|c|}
\hline & Hedges & Boosters \\
\hline Linguistics & 1485 & 674 \\
\hline Geography & 1189 & 478 \\
\hline Physics & 251 & 99 \\
\hline Total & 2922 & 1251 \\
\hline
\end{tabular}

Table 2: H\&B distribution in English corpus

Table 2 shows the overall distribution of hedges and boosters in the English part of the corpus for three selected disciplines, with linguistics containing half of the total hedges and boosters and geography containing nearly half of the total hedges and less than $40 \%$ of the total boosters in the English corpus, and physics containing less than $10 \%$ of the total hedges and almost $8 \%$ of the total boosters. Hedges exceeded boosters in all three disciplines for about 50\%. Physics is underrepresented in the number of hedges and boosters compared to other two disciplines, since natural sciences deal mostly with numerical data and more precise findings which do not demand frequent use of hedges and boosters. This result coincides with Hyland (1998) research findings with more recorded cases of hedges and boosters in social sciences and humanities. 


\begin{tabular}{|l|c|c|}
\hline & Hedges & Boosters \\
\hline Linguistics & 574 & 229 \\
\hline Geography & 404 & 321 \\
\hline Physics & 197 & 142 \\
\hline Total & 1175 & 692 \\
\hline
\end{tabular}

Table 3: H\&B distribution in Serbian corpus

Table 3 describes the use of hedges and boosters in Serbian corpus in three textbooks from the same three disciplines (linguistics, geography and physics). The total occurrences of hedges and boosters in Serbian language corpus are slightly smaller than in English language corpus. Similarly to the results for English corpus, the total number of hedges exceeds the total number of boosters, by almost a half in linguistics, whereas in geography and physics the hedges exceed boosters by only $8 \%$ and $7 \%$ percent respectively. The total number of markers across disciplines ranges from nearly half of the total hedges and slightly over $30 \%$ of the total boosters in linguistics, than less than $40 \%$ of the total hedges and just over $40 \%$ of the total boosters in geography to less than $20 \%$ of the total hedges and just over $20 \%$ of the total boosters in physics.

To sum up, the overall distribution of hedges exceeds the overall distribution of boosters in both languages in all three disciplines. Linguistics subcorpus has the highest number of occurrences for both items in two languages. Geography subcorpus occupies the second position and physics subcorpus records the smallest numbers for both items. 


\subsection{Distribution by category}

It is possible to categorize hedging and boosting devices into different categories. That has given rise to diverse taxonomies for their categorisations. The present study will examine the corpora based on Hyland (2004) taxonomy of hedges and boosters into five main categories:

\section{Hedging categories}

1. modal verbs: can, may, might...

2. lexical verbs: doubt, suggest...

3. adverbs: likely, possibly...

4. adjectives: frequent, noticeable...

5. nouns: opinion, idea...
Boosting categories

1. modal verbs: must, will...

2. lexical verbs: confirm, find...

3. adverbs: certainly, obviously...

4. adjectives: evident, definite...

5. nouns: confidence, fact...

\begin{tabular}{|l|c|c|}
\hline Category & Hedges & Boosters \\
\hline Adjectives & 340 & 239 \\
\hline Adverbs & 545 & 146 \\
\hline Nouns & 187 & 354 \\
\hline Verbs & 1850 & 512 \\
\hline Total & 2922 & 1251 \\
\hline
\end{tabular}

Table 4: Most frequent hedges and boosters in English corpus

As Table 2 and Table 3 show that hedges outnumber boosters in university textbooks in both English and Serbian language corpora in three selected disciplines. The present section further examines the instances of hedging and boosting categories in selected disciplines in both languages. Table 4 shows the frequency of different hedging and boosting devices in English language corpus. With respect to verbal hedges, 5 different modals and 7 lexical verbs were identified, amounting to a $63.31 \%$ of the total. Can $(\mathrm{n}=577)$, may $(\mathrm{n}=407)$, should $(\mathrm{n}=264)$ and $\operatorname{claim}(\mathrm{n}=64)$ and seem $(\mathrm{n}=67)$ were the top five in terms of frequency in all disciplines. The relative incidence of hedges of this type was the highest in linguistics and geography. Regarding adverbs, 6 different instances were detected as hedges with $18.65 \%$ of the total hedges. The items most commonly employed were often $(\mathrm{n}=334)$, generally $(\mathrm{n}=84)$ and typically $(\mathrm{n}=82)$ and they were the top three in geography and linguistics. Generally and typically were top two in physics with 20 and 9 instances respectively, whereas often was not found in physics textbook. 
Concerning adjectives, 6 different adjectives were detected as hedges with only $11.64 \%$ of the total hedges. Most frequent among the detected items were major $(\mathrm{n}=123)$ and large $(\mathrm{n}=142)$ with linguistics most heavily hedged (over $60 \%)$ and physics least heavily hedged (less than $5 \%$ ). As with nouns, only 5 different hedging nouns were employed in English corpus with only $6.40 \%$ of the total hedges. The most commonly used items were idea $(\mathrm{n}=127)$ and evaluation $(\mathrm{n}=41)$ and they were the top two in linguistics and geography.

Regarding verbal boosters, which accounted for $63.31 \%$ of all boosting categories, most frequently employed items were modals: cannot $(\mathrm{n}=206)$, must ( $\mathrm{n}=249)$, and lexical verbs: show $(\mathrm{n}=103)$, assure $(\mathrm{n}=49)$ were the top four in terms of frequency in geography and physics. As with adverbs, 6 different adverbs were employed as boosters with $18.65 \%$ of the total boosters. Most frequent among the adverbs were precisely $(\mathrm{n}=38)$, fully $(\mathrm{n}=33)$ and they were the top two only for geography. With regard to adjectives, 7 different adjectives were detected with only $11.64 \%$ of the total boosters. Among the most frequent were certain $(\mathrm{n}=90)$, clear $(\mathrm{n}=96)$, total $(\mathrm{n}=67)$ which were also the top three for linguistics and geography. With respect to nouns used as boosters, only 5 nouns were found in the English corpus with only $6.40 \%$. The most frequently employed items were evidence $(\mathrm{n}=106)$ and fact $(\mathrm{n}=196)$ and they were the top two in linguistics and geography.

The same taxonomy was applied to Serbian corpus for the purposes of this research:

Hedging categories

1. modal verbs: mocii, znati...

2. lexical verbs: verovati, pokušati...

3. adverbs: moguće, delimično...

4. adjectives: ̌̀esto, primarno, retko...

5. nouns:ideja, tvrdnja...
Boosting categories

1. modal verbs: morati, trebati...

2. lexical verbs: smatrati, ukazati...

3. adverbs: jasno, neophodno...

4. adjectives: očigledan, definitivan...

5. nouns: poverenje, dokaz, činjenica... 


\begin{tabular}{|l|l|l|}
\hline Category & Hedges & Boosters \\
\hline Adverbs & 349 & 257 \\
\hline Nouns & 51 & 53 \\
\hline Verbs & 505 & 354 \\
\hline Adjectives & 270 & 28 \\
\hline Total & 1175 & 692 \\
\hline
\end{tabular}

Table 5: Most frequent hedges and boosters in Serbian corpus

Table 5 shows the most frequent categories of hedges and boosters detected in Serbian language corpus in three disciplines. Regarding verbal hedging devices, 4 different modals and 7 lexical verbs were identified, amounting to a $42.98 \%$ of the total hedges. Moci $(\mathrm{n}=379)$, znati $(\mathrm{n}=15)$, pretpostavljati $(\mathrm{n}=25)$ and razmatrati $(\mathrm{n}=61)$, were the top four in terms of frequency. The relative incidence of hedges of this type was the highest in linguistics. As with adverbs, 6 different instances were detected as hedges with $29.70 \%$ of the total hedges. The most commonly employed adverbs were uglavnom $(\mathrm{n}=142)$ and moguce $(\mathrm{n}=69)$ and they were the top two in geography and linguistics. Uglavnom was the top hedged adverb in physics with 40 instances, whereas other instances of adverbs were found only in 1 to 4 instances in physics textbook. Concerning adjectives, 6 different adjectives were detected as hedges with only $22.98 \%$ of the total hedges. Most frequent among the detected items were cest $\left.^{(} \mathrm{n}=184\right)$ and primaran $(\mathrm{n}=142)$ with geography and physics most heavily hedged. Cest was the adjective with over 60\% occurrence in geography and over 35\% in physics. Linguistics was least heavily hedged (less than $5 \%$ ). With regard to nouns, only 5 different hedging nouns were employed in Serbian corpus with only $4.34 \%$ of the total hedges. The most commonly used items were ideja $(\mathrm{n}=18)$ and misjlenje $(\mathrm{n}=9)$ and they were the top two in linguistics and geography.

The findings with verbal boosters were the following: modal and lexical verbs together accounted for $51.16 \%$ of all boosting categories. Most frequently employed items were modals: trebati $(\mathrm{n}=158)$, morati $(\mathrm{n}=90)$, which were the top two in terms of frequency in geography and physics, and lexical verbs: smatrati $(\mathrm{n}=34)$, ukazati $(\mathrm{n}=31)$, which were the top two in terms of frequency in geography. Ukazati was also the top boosting verb in linguistics. Regarding adverbs, 8 different adverbs were employed as boosters with $37.14 \%$ of the total boosters. Most frequent among the adverbs were jasno ( $\mathrm{n}=83)$, potpuno $(\mathrm{n}=81)$, 
neophodno $(\mathrm{n}=49)$ and they were the top three only for geography. With regard to adjectives, 6 different adjectives were detected with only $4.05 \%$ of the total boosters. Among the most frequent were apsolutan $(\mathrm{n}=11)$ and definitivan $(\mathrm{n}=6)$ which were also top two geography and physics. With respect to nouns used as boosters, only 4 nouns were found in Serbian corpus with only 7.66\% of the total boosters. The most frequently employed items were dokaz $(\mathrm{n}=16)$ and rimjenica $(n=33)$ and they were the top two in linguistics and geography.

To summarize, distribution of categories employed as hedges and boosters in university textbooks in English and Serbian languages showed that verbs are dominant as hedging and boosting strategy, with significantly smaller number of incidence in Serbian part of the corpus.

\section{Conclusion}

The findings of this research support the fact that social sciences seem to have more interpretative style, which results in more hedges and boosters opting for subjectivity, whereas natural sciences have more precise, fact-oriented style, which results in fewer hedges and boosters and opting for objectivity. In addition, hedges assign an active role for the reader to be involved into the negotiations and reformulations of the propositional text, while boosters may assign a passive role to the reader acting as "an assurance in the certainty of arguments that require no feedback" (Lewin, 2005).

Regarding specific disciplines, linguistics, geography and physics in English and Serbian language, hedges and boosters found in the examined corpora balance subjective evaluation and objective information to involve the reader into understanding the proposition. Also, English and Serbian language follow the variations which are regulated both by general rules of academic communication styles for both languages as well as the norms and practices of particular disciplines.

The revealed unequal distribution also suggests that discipline specific hedging and boosting strategies do exist both in Serbian and English academic discourse. Therefore, certain pedagogical implication may arise from these findings such as understanding and use of hedges and boosters in English written academic communication as well finding their formal and functional equivalents in Serbian written academic communication. It is generally accepted that hedging and 
boosting strategies are important for understanding academic discourse of university textbooks, since both types of strategies make "a text more readerfriendly since they allow for negotiation between the writer and the reader...students do have to learn which kinds of assertions should be hedged... and the concomitant lexicogrammatical structures to accomplish these functions." (Milivojević \& Radojičić, 2015). Moreover, the research may grasp differences and similarities in the use of hedging and boosting devices in both languages and provide learners with guiding principles regarding the use of hedges and boosters in academic discourse in specific disciplines.

\section{References}

Halliday, M. A. K. (1978). Language as social semiotic: the social interpretation of language and meaning. London, United Kingdom: Edward Arnold.

Hyland, K. (1998). Hedging in scientific research articles. Amsterdam: John Benjamins.

Hyland, K. (2004). Metadiscourse: exploring interaction in writing. New York, United States: Continuum Discourse Series.

Hyland, K. (2005). Metadiscourse: Exploring interaction in writing. London: Continuum International Publishing Group.

Hyland, K. (2009). Teaching and Researching Writing. Harlow: Pearson Education Limited.

Lewin, B. A. (2005). Hedging: an exploratory study of authors' and readers' identification of 'toning down' in scientific texts. Journal of English for Academic Purposes, 4, 163 178.

Milivojević, N., \& Radojičić, S., (2015). Types of cohesion and hedging devices in scientific texts - a classroom perspective. In I. Lakić, B. Zivković, \& M. Vuković (Eds.), Academic Discourse across Cultures (pp. 114-129). UK: Cambridge Scholars Publishing. Retrieved from https://doctiktak.com/academic-discourse-acrosscultures.html

Varttala, T. A. (2001). Hedging in scientifically oriented discourse: Exploring variation according to discipline and intended audience. (Doctoral dissertation. University of Tampere). Retrieved from https://tampub.uta.fi/bitstream/handle/10024/67148/951-44-5195-3.pdf

Vassileva, I. (2001). Commitment and detachment in English and Bulgarian academic writing. English for Specific Purposes, 20, 80-102. Retrieved from https://www.sciencedirect.com/science/article/pii/S0889490699000290 


\title{
Authentic Scientific Articles in ESP Master Courses: Incentives or Demotivators
}

\author{
YULIA SIZOVA
}

\begin{abstract}
The paper focuses on the anthropocentric features of the ESP master course that actually combines English for Academic Purposes, English for Occupational Purposes and English for Individual Purposes. Such understanding of ESP essence means that such a course can focus students on continuing education in the foreign-language environment, mastering a profession and implementation of professional activity in multicultural environment, achievement of other personally significant prospects. It is important to emphasize that the aforementioned approach in the centre of which there is a linguistic persona, adverts primarily the sphere of mastering reading. Therefore authentic scientific articles use as learning materials in an ESP master course seems to be relevant and justified. The author defines advantages and disadvantages of tailoring master courses with such articles and puts a great deal of thought into the matter of their being incentives or demotivators in an ESP classroom.
\end{abstract}

Keywords: • anthropocentric approach $\bullet$ knowledge mining $\bullet$ ESP master course $\bullet$ authentic scientific article $\bullet$ Education Space characteristics $\bullet$

CORRESPONDENCE ADDRESS: Yulia Sizova, Senior Lecturer, Plekhanov Russian University of Economics, Department of Foreign Languages №1, Stremyanny lane 36, Moscow, 117997, Russian Federation, e-mail: ju-si@mail.ru. 


\section{$1 \quad$ Introduction}

Teaching English for Specific Purposes (ESP) is aimed at the foreign-language communicative competence formation in professional sphere. Modern Education Space is affected by new teaching technologies development and these factors cause changes in the syllabus of ESP master course in Plekhanov Russian University of Economics. Structural and contents priorities shift to the direction of 'the personality in language', to individual 'knowledge mining' in close cooperation with the teacher-consultant. The ESP master course actually combines English for Academic Purposes, English for Occupational Purposes and English for Individual Purposes.

A person needs self-perception in the world around, understanding of his mission. Everything around shapes his individual personality and is reflected in his behaviour, actions, oral activity through the links with the state of awareness, thinking and speech. Recently linguistic science pays more attention not to language structures description, but considers structural processes through the notion of 'linguistic persona'. A person lies in the area of focus, i.e. anthropocentric approach prevails. A native speaker is being considered as an anthropological phenomenon (Kubrjakova, 1995) and new trend in linguistic phenomenon study was announced - anthropocentrism, where the language is mastered through the prism of human feelings in language, the movements of his thought, cognitive and cogitative activity (Lavrentjeva, 2015).

\section{Relevance of Authentic Scientific Articles Use in an ESP Classroom}

\subsection{Education Space Characteristics}

The task of an English language teacher nowadays is to create a balance between society needs, students' motivation and University's concerns. That is why it is worth going deeper into the specific character of modern Educational Space where ESP is taught. The most important characteristics of it are:

- Continuity which means that each element of Education Space contributes into the goal function of the whole system of education - a modern professional personality formation; 
- Hierarchy that manifests itself in Education Space elements connection, their mutual operation and subordination;

- Multidimensionality reflected in different factors, attractors and facilitators of existing society;

- Sustainability is what that Education Space always exists regardless time and other factors contributing into society;

- Liveliness for Education Space together with all its elements is mobile and variable. In case one educational institution closes its functions are delegated to another one and the system itself remains;

- Openness for Education Space inevitably meets all the demands of a modern social demand;

- Territoriality reflecting in the fact that, on the one hand a certain Education Space is reflected by its location and on the other hand it works towards supraterritorialism and supranationalism of Scientific Education Space;

- Technological effectiveness that is "reflected in the use of best technological practices tests and endorses new ones" (Zinkevitch, Andryukhina, Ivanova, Kuznetsova, S. N. Ledeneva, \& T. V. Ledeneva, 2011, p. 11).

\subsubsection{Master Course Characteristics}

Currently the boarders of traditional content areas change and ESP teaching instructions are changing under the stimulus of professional context. In the framework of anthropocentric approach our University lecturers may tailor the course in such a way that it will correspond to an up-to-date competence based cross-cultural communicative activity development in the conditions of students' academic mobility enhancement and internationalization of educational programs in general. In this context ESP Master Course actually combines English for Academic Purposes, English for Occupational Purposes and English for Individual Purposes. Such understanding of ESP essence means that such a course can focus students on continuing education in the foreign-language environment, mastering a profession and implementation of professional activity in multicultural environment, achievement of other personally significant prospects. 
ESP Master Course objective is the development of new and improvement of the general and language skills acquired in a bachelor course, conformation of the students' educational results to the qualifications that signify the course completion. The educational and methodical complex of the course considers general subject competences necessary for future professional activity. Those of higher-priority are:

- Communicative Competence in the sphere of professional activity in communicative situations with native speakers (as the tale of linguistic, speech and other elements);

- Information and Analytical Competence, that presupposes the ability to work with English-language sources of information;

- Managerial Competence taking into account social engagement of master students;

- Sociocultural Competence which means willingness to live and interact in a multicultural society mainly in academic and professional spheres;

- Scientific-research Competence, i.e. the use modern scientific research methods, learning the basics of master dissertation, scientific report, reference list preparation and etc.;

- Translator's Competence in professional sphere;

- Academic Skills that allow undertake further study independently. The Plekhanov Russian University ESP Master Course is tailored on a crossdisciplinary basis, anthropocentric and reflective approaches and stipulates the abovementioned competences integration and master students' academic autonomy and mobility combination.

So, our ESP Master Course is rich in authentic training toolkit, real-life and problem-solving tasks, and project work. Course materials are pragmatically valid and may be adapted to the changing situation on a labour market. Staying on to be the educand for master students, English language becomes to a greater extent a tool for in-depth knowledge in professional sphere acquired through mastering of majors. This is achieved by authentic scientific articles reading, self-directed work with other sources of information to the professional point. This activity has been aimed at the developing master students' skills to work with text production and text awareness and is done within the framework of 
anthropocentric approach, and its appearance was predicted as far back as 1988 by Serebrennikov (Serebrennikov, 1988).

Thereby it is evident that new waves of scientific research specify modern Education Space characteristics and the use of authentic scientific articles is quite relevant in this respect. All the above mentioned factors in 2.1. and 2.1.1. show the relevance of authentic scientific articles use in an ESP classroom.

\section{Scientific Article Value in ESP classroom}

Brin, a researcher of authentic issues, defines four types of authenticity: "authenticity of texts used in pedagogical activity; authenticity of these texts comprehension by students; authenticity of class assignments; and even authenticity of social situation in the classroom" (Lobanova \& Tumakova, 2015, p. 1202). The lecturers of Plekhanov Russian University of Economics while creating the ESP course for master students focus on authenticity of texts. In the framework of anthropocentric approach such articles are being chosen that "native speakers produce for native speakers, and not created for studies only" (Khaleeva, 1998, p. 15), for only such texts are able to broaden students' language-socio-cultural competence, and solve pragmatic issues of vocabulary enhancement. There are many types of texts of economic orientation which correspond to the subject and communicative tasks solved in various situations of communication. Authentic texts for master students in economics have to 'provoke' students on statements, force them to get into discussion. For this purpose texts have to be professionally focused, well-structured, and not too long. Scientific articles meet all there requirements and feed well into ESP master course.

Numerous competences are featured by different researches all over the world that can be nourished in the course of work with authentic scientific articles. They are mentioned below in order of importance, defined by master students of Plekhanov Russian University of Economics upon the anvil with the author of the current paper:

- Awareness of international research writing standards;

- Research writing skills;

- Applying research skills in a master's paper; 
- Capacity for analysis and synthesis;

- Critical thinking;

- Autonomous learning;

- Translation skills;

- Information management skills;

- Ability to apply knowledge in practice;

- Profound knowledge in the field of study;

- Ability to work in a multicultural business environment.

As far as drawing up mind maps is a very popular activity in the process of foreign language mastering hereinafter the author presents the one created by master students reflecting their vision of an authentic scientific article text potential.

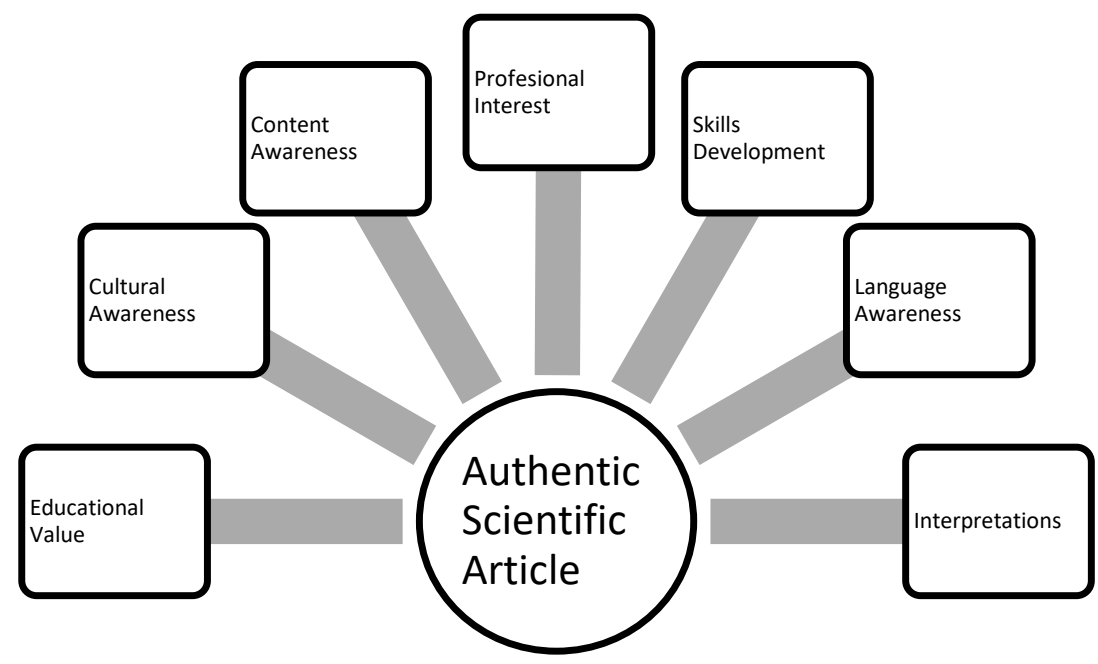

Figure 1: Authentic Scientific Article Text Potential, designed by students

\section{$4 \quad$ Motivation Research}

It is notable that no two students go about the value of working with the authentic scientific article texts in exactly the same way. They are all get inspired and motivated in different ways, they have their own reasons to like or dislike this activity, to try one's hardest or skirt around. 
The author of the current paper has carried out a research in a master course aimed at figuring out the attitude of master course students towards authentic scientific articles study. An obligatory element - an authentic scientific article has been introduced into each class of the ESP master course. The research methods used were: opinion poll, questionnaire, overt observation. Total number of master students involved was 120. The research has taken two years, and master students of Plekhanov Russian University of Economics has been involved in.

The top priority reason why master students are ready to work with authentic scientific article texts is the fact that they consider these texts to be the tool for mastering ESP course in general (110 answers). Running second is the use of this activity for master's thesis work preparation (90 answers). Master students stress that the information they learn from authentic articles studied in the ESP classroom is extremely useful for their future defence of a master thesis. The third place (87 answers) - interest; the forth (82 answers) - possibility of this knowledge application in their current job allowing for promotion; 'It makes me feel good about myself' (54 answers); and 'I really need it for my professional activity' ( 9 answers).

It can be observed that personal motives are number one. Work with the text of the scientific article is considered as means to satisfy cognitive interest, valuable source of information, good possibility to keep sharp cogitative activity, and to raise self-esteem. The motives connected with work are not of the top priority, and real need of use of this type of activity for professional needs was noted only by 3 master students, though 82 people believe it to be a potential opportunity for career prospects. The majority of answers fix academic motivation. Thus, it is possible to state that professional motivation of such activity as working with authentic scientific articles for master students is not defining.

What factors support our master students in work with authentic scientific articles texts and which ones interfere with their progress in using of this kind of activity.

The obvious favourite among supporting factors is not revealed. The identical number of answers (67) has been given to such points as it is interesting to be engaged' and 'those purposes for the sake of which I have come to ESP master course remain'. 66 and 67 students have respectively noted that they 'notice 
progress and it is inspiring', and 'it would be a pity to leave behind the knowledge gained'. Both answers demonstrate that results of educational process are well noticeable, and appear to be an important motivating factor for master students.

Among the factors hampering the progress in ESP with the authentic scientific articles texts is heavy workload (88). Master students in Russia study in the evenings and $90 \%$ of them have a job. Studying authentic scientific articles texts require much effort and time. Reading for detail and translation activities are usually homework assignments, so, sometimes it is challenging even for highly motivated students. Quite self-critically master students allocate also the personal reasons of poor progress in ESP course filled with authentic scientific articles texts: laziness (25), low level of proficiency in language (16), disorganization (15). Only 5 respondents have noted difficulty of material as the factor interfering progress.

From 120 master students participating in the poll, 22 have recorded the desire to remove authentic texts of scientific articles from the program of a course, but 98 people have noted that they would like to continue to work with such texts.

The conducted research allows providing preliminary findings on psychological features of master students training using authentic scientific article texts. It has shown that professional motivation is not defining. Among the factors hindering master students to have progress in ESP course rich with authentic scientific articles texts are lack of time and personal reasons. And the important supporting and motivating factor for master students in this case is apparent progress in mastering English language in general.

\section{Acknowledgments}

The author of the current paper is very grateful to all the people who made this article possible: master students of Plekhanov Russian University of Economics in program tracks 'Financial Management', 'Management', 'Economics' and the Head of the Department of Foreign Languages № 1 Irina L. Ekareva.

\section{References}

Khaleeva, I. I. (1998). Fundamentals of the theory of foreign speech understanding. Moscow, Russia: High School. 
Kubrjakova, E. S. (1995). Evolution of linguistic ideas in the second part of the 20-th century (experience of paradigm analysis. In Yu. S. Stepanova (Ed.), Language and science of the late 20-th century (pp. 144-238). Moscow, Russia: Russian State University for the Humanities.

Lavrentjeva, E. A. (2015). Towards the issue of anthropocentric approach implementation into the process of English language teaching in a non-linguistic university. Bulletin of Moscow International Higher Business School MIRBIS, 4, 70-73. Retrieved from https:/ / elibrary.ru/item.asp?id=25353051

Lobanova, E. Yu., \& Tumakova, N. A. (2015). Authenticity of the text in the foreign language classroom. Young Scientist, 10, 1201-1203. Retrieved from http://portal.tpu.ru/SHARED/k/KEY/publications/Tab/6moluch_91_ch13. pdf

Serebrennikov, B. A. (1988). The role of human factor in the language. The language and the worldview. Moscow, Russia: Nauka.

Zinkevitch, N. A., Andryukhina, T. V., Ivanova, E. E., Kuznetsova, N. V., Ledeneva, S. N., \& Ledeneva, T. V. (2011). English masters course. Moscow, Russia: Iris Press. 


\title{
Creating an English-Croatian Maritime Dictionary
}

\author{
TOMISLAV SKRAČIĆ
}

\begin{abstract}
Maritime English has become an essential part of a seafarer's training after English was recognised as the common language for international maritime communications and its teaching aspects elaborated by the International Maritime Organization. Dedicated textbooks, manuals and dictionaries represent unavoidable tools in teaching and acquiring competence in Maritime English. Responding to the gap in the Croatian market, Bisera Plančić and Tomislav Skračić created an English-Croatian Maritime Dictionary, published by Faculty of Maritime Studies in Split in July 2017. Although ESP teachers engage in creating dictionaries typically out of sheer need and love, it is vital to carefully consider a) the concept of the dictionary; b) market needs and competition; c) target users; d) scope and size of the book; e) selection of co-author(s); f) co-workers (reviewers, proof-readers, graphic designers...); g) editorial support (if any); h) publishing possibilities; i) maintenance / transfer of copyright to the publisher; and last but not least, j) personal benefits and satisfaction. The paper discusses the concept, dilemmas, compromises, editorial conflicts and other challenges that arise when attempting to write a comprehensive but user-friendly dictionary of maritime terminology. Hopefully this first-hand experience will be useful to others when undertaking similar lexicographic ventures.
\end{abstract}

Keywords: $\bullet$ Croatian $\bullet$ Maritime English $\bullet$ Dictionary $\bullet$ Concept $\bullet$ Terminology $\bullet$

CORRESPONDENCE ADDRESS: Tomislav Skračić, MA, Senior Lecturer, University of Split, Faculty of Maritime Studies, Ruđera Boškovića 37, 21000 Split, Croatia, e-mail: tomislav@pfst.hr. 


\section{$1 \quad$ Introduction}

In the world of ESP education, the role of the English teacher, or practitioner as some prefer to say, have been discussed many times in great detail, and various definitions have been suggested, but it seems that a simple diagram can illustrate the complexity of the situation (Figure 1):

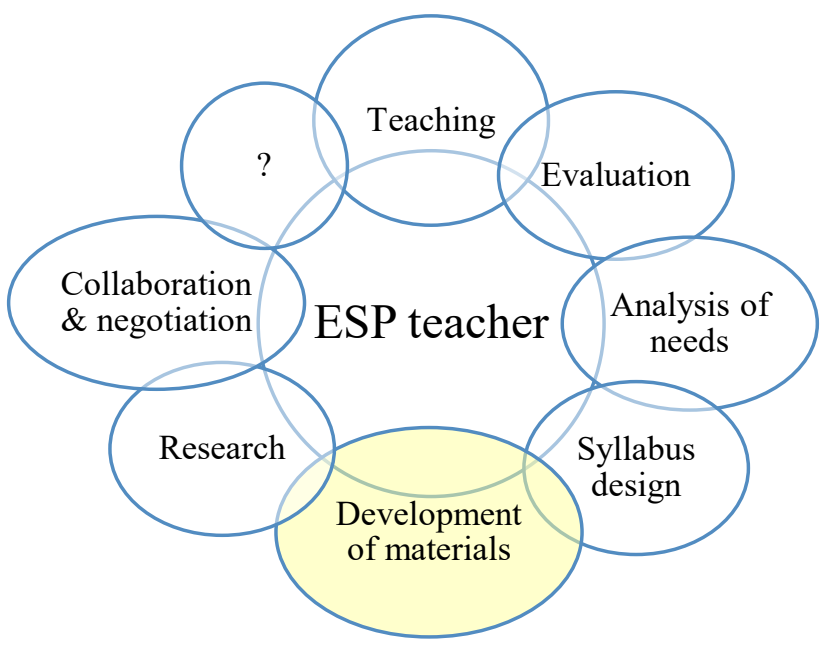

Figure 1: The roles of an ESP teacher (Ahmed, 2014; Vodopija, Skračić, \& ŽanićMikuličić, 2017)

In addition to delivering lectures and performing exercises, providing explanations and advice, acting as team coaches, evaluators and needs analysts, managers and collaborators with both students and subject specialists, ESP teachers create and/or adapt teaching tools and materials. ${ }^{1}$ They often act as course designers and materials providers due to the lack of materials for ESP courses - the more specialized the course, the greater the rarity of teaching materials. Provision of materials includes choosing materials, adapting material when published materials are unsuitable, and writing his/her own materials, including course books and dictionaries. ${ }^{2}$

\footnotetext{
${ }^{1}$ More about the roles of ESP teachers in: Vodopija et al, Marine Engineers' Views on ESP Teachers, Book of Proceedings of IMSC 2017, 7th International Maritime Science Conference, April 20-21, 2017, Solin, Croatia, ISSN 1847-1498, pp. 141-147; also in: Milevica Bojović, Teaching Foreign Language for Specific Purposes: Teacher Development, 31st Annual ATEE Conference, Association of Teacher Education in Europe, pp. 487-493.

2 The author published two English textbooks for the students of maritime studies (Waypoint, 2010 and Fairway, 2017). Bisera Plančić co-authored Englesko-brvatski pomorski slikoovni rječnik (Split, 2008).
} 
According to British freelance lexicographer Sinda Lopez, there is a paradigm that can be applied to writing any dictionary, despite the syntagmatic features (i.e. specific aspects) of the individual projects:

1. Compilation of a framework: building the corpus, having in mind a welldefined target market, age, level and purpose of the user.

2. Analysis and categorisation of the list of words to be covered; categorizing the different meanings and uses, and selecting natural examples and contexts to illustrate those meanings.

3. Framework construction: distribution of headwords; building the entries, inserting additional information (gender, irregular forms...) and notes, election of punctuation, inserting tags in electronic versions...

4. Translation of the entries: preferably arriving at a publishable two-line entry. However, language is not an exact science and translation is a fine art, and the perfect translation can still elude. In other words, sometimes a 6-line entry is better than a 2-line entry.

5. Editing: boiling the material down to tight but comprehensive entries that capture the essence without taking up any unnecessary space. This part is a delicate balancing act full of compromise.

6. Consistency checks.

7. Final edit and proofreading: to eliminate any typos and remaining errors before passing on the finished text for printing (Lopez, 2006).

\section{Situation on the market}

The gap on the market was the main motive for undertaking the painstaking adventure of creating a dictionary. There exist several English-Croatian or Croatian-English dictionaries covering maritime terminology. They vary greatly in terms of their target population, size, focus and concept. Here are some of them (in chronological order).

- Englesko-brvatski ili srpski pomorski poslouni rječnik (Ljubomir Predojević, Otokar Keršovani Opatija, 1988, 25x17cm, 894 pages) is a one-way English-Croatian/Serbian dictionary focusing on maritime business and industry.

- Croatian or Serbian English Maritime Dictionary (Boris Pritchard, Aris Spinčić et al; Školska knjiga Zagreb, 1989) is also a one-way Croatian/Serbian-English dictionary. It provides a comprehensive 
collection of maritime terms that are organised as clusters instead of "list of words", often featuring supplementary culture or business notes inside the brackets.

- Croatian-English Maritime Dictionary / Hrvatsko-engleski rječnik pomorskog nazivlja; Marijan Urbany, Boris Pritchard et al; Školska knjiga Zagreb, 1991, 17x24cm, 285 pages. Another product of the excellent ESP team from the University of Rijeka.

- Pomorsko-brodogradevni englesko-brvatski i hrvatsko-engleski priručni rječnik (Katja Buble, Olga Ljubić-Karanović; Eduka, Split, 1997, 22 cm, 290 pages) is a two-way English-Croatian and Croatian-English dictionary. Having a limited scope, it focuses on ship-building but covers other maritime activities less efficiently.

- Englesko-hrvatski rječnik pomorskih izraza i termina / English Dictionary of Marine Words and Terms, Željko Stazić, self-published in Split, 2004, 24 $\mathrm{cm}, 488$ pages. The dictionary was created by an author with extensive seafaring and academic experience and thus represents a valuable tool in ESP learning. The most striking quality of this work is that it covers a wide area. Another essential feature is its clarity: English entries are listed with Croatian equivalents referring to maritime context, with little beyond a translation. There is not any other information, such as meanings of the terms in other contexts, references for compounds, information about gender, irregular forms or pronunciation. The end result is a very neat work, but limitations of such dictionaries are obvious. For example, it appears that a user has to look up several different entries scattered across the body of the dictionary, to find out the meaning of the term "two-stroke single-acting exhaust-ported diesel engine".

- By contrast, the newest dictionary created by Maritime English team from Rijeka, reflects an encyclopaedic approach (Josip Luzer \& Aristide Spinčić, reviewed by B. Pritchard: Englesko-brvatski enciklopedijski brodostrojarski rječnik, Školska knjiga Zagreb, 2013, 1542 pages). Here the headword is flanked by ample information about its part of speech, pronunciation, gender, irregular forms, etc. In addition, words are placed in various contexts and often supported by comments and notes in the brackets. However, this comprehensive approach inevitably focuses on one aspect of maritime industry (i.e. marine engineering). If it involved all other aspects (navigation, boating, ship structure and construction, 
transport technologies, etc.) the volume of the project would be multiplied by 10 or $12 \ldots$ and would never been completed, not during the lifetime of the team that contributed to this edition (20 people altogether, including editors, reviewers, advisors, proof-readers, and graphic assistants).

\section{$3 \quad$ Concept and coverage}

As explained earlier, the basic idea was to bridge the gap on the market and to produce a comprehensive dictionary of maritime terminology. Leaving the Croatian-English part to be dealt with when and if possible, the Plančić-Skračić dictionary was designed as a one-way street, providing Croatian translation of English words, with an emphasis on their contexts and nuances in practical use of a large population engaged in various branches of maritime industry.

The targeted population consists of all those whose need for such a dictionary has been recognised over the years, and the ones who, in authors' opinion, may find the dictionary a useful tool in their study and career, including seafarers, students, teachers at maritime higher education institutions and any person engaged in maritime affairs in any way. This affected editorial decisions about the shape of the dictionary at all levels, from coverage to the selection of information. ${ }^{3}$

Firstly, the coverage is exceptionally wide, including: navigation, ship stability and construction, marine engineering, onboard equipment, power systems and electronics, maritime technologies, meteorology, nautical tourism, management, economy of shipping, sea-borne transport, maritime law, insurance, medicine and other trades closely associated with maritime affairs.

On the other hand, the authors found it necessary to place a huge corpus of nonmaritime terms into the body of the dictionary. The marine engineers, for example, whether on board or at school, communicate at many levels with different people. They need to know general terms and everyday phrases to get through the day, develop social skills and, avoid misunderstanding that can affect

\footnotetext{
${ }^{3}$ More about editorial and other aspects considered when creating a bi-lingual dictionary in: Deuter, M. (2004): A tale of two halves: writing a bilingual dictionary for students of English. In: Williams, G. I Vassier, S. (Eds.), Proceedings of the 11th EURALEX International Congress, vol. 1. Lorient: EURALEX, pp. 245-254.
} 
their career or safety at sea, send an email to purchase spare parts, write a CV or a report, deal with administration in foreign countries, order a meal or drink.

In addition, the dictionary features the entries referring to student and academic activities, thus representing a valuable source of explanation and information for the academic community, and contributing to the development and dissemination of maritime science.

Moreover, whenever possible and deemed necessary, the dictionary contains loanwords, regional idioms, geographical names, neologisms, synonyms, homonyms, examples of using the same words in different contexts, etc.

Finally, the dictionary incorporates phrasal verbs as separate clusters, as well as the most common general terms, therefore enabling a more accurate and comprehensive understanding of the specific maritime terminology.

Obviously, at the stage of compiling the corpus, the main issue was: where to stop and where to set the limits? This created a number of dilemmas, arguing, even conflicts between the co-authors and other unpleasant situations. There were no guidelines there, except for the judgement of the authors themselves, based on common sense, experience and plenty of compromise.

\subsection{Headword information}

Trying to reach a practical balance, we decided that our dictionary would not be a mere list of words and compounds, without a context or examples. Guided by the pedagogical approach, some authors provide as few translations as possible and give the learner the smallest number possible of the most productive translations (Deuter, 2004). However, it often occurs that a translated standalone word does not help much without context. We also decided that the length of entries should be reasonable, examples justified, and additional information not really needed by our target users eliminated. Thus the headword "head" was organised in the following way to facilitate the user's search: 
head (adj) glavni, vodeći, pramčani

$\sim$ line pramčano uže, (kolokv) provijera; office sjedište, glavni ured, uprava, direkcija; pipe glavni vod; rope pramčani konop; sail prednje jedro; sails sva jedra smještena ispred (prvog) jarbola; sea valovi u pramac

head (n) glava; razum; osoba, pojedinac; vođa, predvodnik; odjeljak, poglavlje; pramac; gornji dio, poklopac

$\sim$ injuries ozljede glave; of finance and accounting voditelj financijskoračunovodstvene službe; of pier vrh gata, krajnji dio gata (prema moru); of professional studies voditelj izvanrednih / stručnih studija; of Professional and Alternative Study for Seafarers voditelj izvanrednog i alternativnog studija za pomorce; of students' office voditelj(ica) studentske službe; $\sim$ of the institution voditelj / ravnatelj institucije; to wind pramcem u vjetar, u vjetar, protiv vjetra; cylinder $\sim$ glava cilindra

head (v) držati kurs, ploviti; voditi, predvoditi, ići naprijed; srljati; stajati na čelu, zapovijedati, prednjačiti; nasloviti

a team of 10 people predvoditi tim od 10 ljudi; ed by predvoden; for uputiti se, krenuti / ići prema

header cijevna komora, sabirni cjevovod, razdjeljivač; nosač

$\sim$ pipe sabirna cijev; $\sim$ tank kolektor, sabirnik; bonding to $\sim$ povezivanje $s$ nosačem; superheater $\sim$ cijevna komora pregrijača pare

headhunter agencija za pronalazak stručnjaka, agencija za posredovanje pri zapošljavanju; lovac na talente; lovac na glave

heading pramčanica; smjer kretanja; naslov, poglavlje; rubrika, tarifni broj $\sim$ direction pravac kretanja; dangers in the $\sim$ direction opasnosti u pravcu kretanja; line pramčanica; marker (HM) oznaka kuta pramčanice / azimuta; No. tarifni broj; Nos. tarifni brojevi; tbr.; number tarifni broj

headland kopno; rt

headlight prednje svjetlo, far

headline pramčani konop; glavni naslov, naslov stupca (u novinama)

head on frontalno, čeono; s pramcem prema

$\sim$ vessel brod koji ima pravo puta; meeting $\sim$ frontalno / čeono približavanje

headphones slušalice

headquarters (HQ) sjedište upravljanja, direkcija, središnjica, stožer an English firm whose is in New York engleska tvrtka čije je sjedište u New Yorku; our is down town naša središnjica / središnji ured / glavni ured je u centru mjesta; Where are the of JPS? Gdje je sjedište JPS-a? 
headrest naslon za glavu

heads brodske sanitarije / zahod; izdaci, troškovi

headstart početak, početna prednost, prednost

head-up motion radar radar s pokazivanjem smjera u pramčanici broda

headway napredovanje broda, napredak, kretanje, brzina napredovanja, gustoća prometovanja, vrijeme slijeđenja; razmak, slijed, odmicanje; uspjeh; visina gather $\sim$ kretati se pramcem; make $\sim$ kretati se naprijed; odmaknuti, napredovati

Given the target users (seafarers, shore-based maritime industry staff, students, teachers...), the headword reflects the compromise as a central concept feature: the headword remains the source of vital information, e.g. its part of speech, irregular forms, BrE or AmE variations, and occasional supplementary explanation inside the brackets.

On the other hand, there is no transcription of the pronunciation, indication of primary and secondary stress. Saving valuable space was not the principal reason: it is sad but true that the vast majority of the dictionary users, despite secondary school leaving certificates, are not able to encode this information.

We also avoided splitting verb entries into transitive, intransitive, and reflexive sections, which often results in a great deal of repetition. Instead, we preferred to provide context to most of the words, to describe how they interact with other words.

\subsection{Compounds}

English teems with compounds, and many of them behave as headwords in their own right (e.g. headhunter, headquarters, headway...). This improves the clarity of the material.

\subsection{Custom and cultural notes}

Occasionally, cultural and custom notes are added to explain features of life in the English-speaking world of maritime affairs (where a translation might give little enlightenment). It can be argued that such elements are not vital for decoding English terms, but we believe they are. After all, from the linguistic 
point of view Maritime English is a specific jargon that implies a specific style embodied in specific grammatical forms (Čulić-Viskota \& Kalebota, 2013).

\subsection{Abbreviations and acronyms}

In our experience, users rarely navigate outside the main body of a dictionary to check the meaning of acronyms and abbreviations in separate lists. This is the reason why we included abbreviations and acronyms (e.g. FW, MOB, RADAR, SOLAS...) into the body of the dictionary - always observing the alphabetical order.

It can be noticed that this approach and editorial decisions heavily contributed to the growth of the lexis body. The dictionary has 570 pages. Nevertheless, it is still relatively light and can fit in a handbag, a briefcase or a small rucksack. And it is not too expensive (around $33 €$ ). Therefore, we believe that - swimming through the sea of compromises - we managed to create a solid and practical ESP product, despite the lack of real editorial support and other constraints related to publishing environment in Croatia.

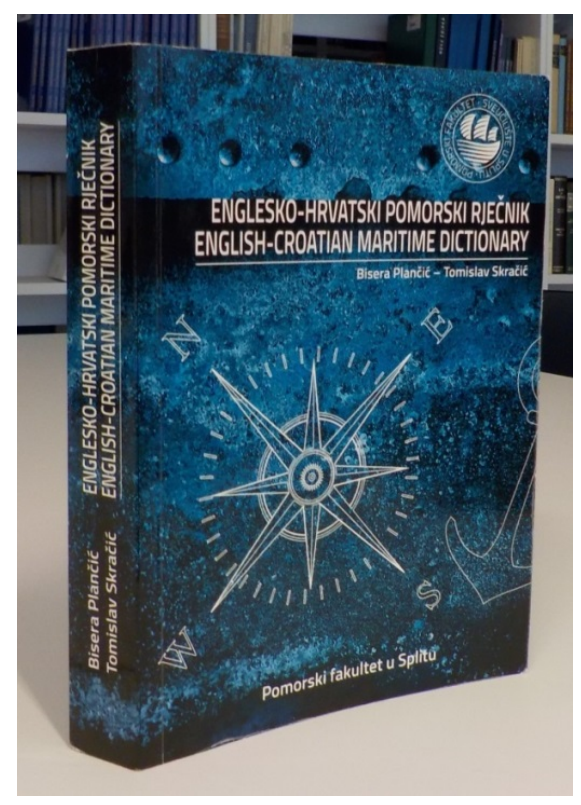

Figure 2: The English-Croatian Maritime Dictionary (photo by the author) 


\section{$4 \quad$ Conclusion}

This paper discusses the dilemmas that arise when attempting to create an ESP product that has not existed on the market. It also provides a real-life insight into the process of creation and publishing, an experience that will hopefully assist future writers in developing quality ESP products.

Because we were not aiming at professional users of language such as translators, but mainly at seafarers and students who are predominantly intermediate learners, the emphasis was more on the pragmatic than on the pedagogical aspect.

Comprising 570 pages, The English-Croatian Maritime Dictionary by Bisera Plančić and Tomislav Skračić uses alphabetic, descriptive and cognitive criteria to arrange the complex lexical corpus. Word clusters attached to leading words provide examples and explanations of terms consisting of one or more lexical units and these associated units can be found as distinct entries at appropriate alphabetic position in the dictionary, whether they refer to the maritime or general vocabulary. The authors have managed to encompass the most relevant maritime terminology, including navigation, ship stability and construction, marine engineering, onboard equipment, power systems and electronics, maritime technologies, meteorology, nautical tourism, management, economy of shipping, sea-borne transport, maritime law, insurance, medicine and other trades closely associated with maritime affairs. In addition to English terms and Croatian equivalents, whenever possible and deemed necessary, the authors provided loanwords, regional idioms and seamen's jargon. Moreover, there are neologisms, synonyms, homonyms, false friends, and examples of using the same words in different contexts.

Additional value of this lexicographic endeavour has been created by incorporating phrasal verbs as separate clusters, as well as the most common general terms, therefore enabling a more accurate and comprehensive understanding of the specific maritime terminology. The dictionary also features numerous entries referring to student and academic activities, thus representing a valuable source of explanation and information for the academic community, and contributing to the development and dissemination of maritime science. 
A comprehensive scope and approach have resulted in bulky materials that required balance between co-authors and between co-authors and publishers. There were no clear road signs - just experience, common sense and judgement of seafarers, students and their teachers. And a great deal of compromise.

It took ten years to create the English-Croatian Maritime Dictionary. At the beginning of the paper, we presented a creation paradigm which can be applied to any process of dictionary creation:

- Compilation of a framework

- Analysis and categorisation of the list of words to be covered

- Framework construction: distribution of headwords; building the entries

- Translation of the entries

- Editing

- Consistency checks

- Final edit and proofreading.

This ideal paradigm corresponds, to a large extent, to the creation of the EnglishCroatian Maritime Dictionary. However, the process of creation was heavily affected by specific aspects that are worth pointing out for practical reasons. For example, why did it take 10 years to complete this work, instead of 3 or 4 ?

First of all, let us not forget that creating ESP material is just one role of an ESP teacher. Secondly, the publishing environment is not the same in all parts of the world. Before, during and after creating any ESP tool, Lopez and other authors from Western world assume the support of the publisher who has a "well-defined target market" in mind, which implies a sound business outcome. In Croatia and, quite likely, other countries that recently passed through a political and economic transition, the state of mind has not changed much, which means that the support is not there and the bulk of non-lexicographic part of the job is done by authors themselves.

Given the modest role of the publisher who financially supports the project but does not function as a coordinator between the authors, proof-readers, reviewers, graphic designers etc., the role of the author becomes crucial in terms of controlling the process. If there are two or more authors, one of them has to be in charge of the master versions of the ESP product. All corrections, changes 
and additions provided by co-authors or other collaborators must be transferred to the author in charge who then introduces the changes into the master document. Otherwise, chaos is inevitable.

All this implies that an ESP teacher engaging in creating ESP products, in addition to all the above mentioned qualities, must have excellent social, communication and diplomatic skills.

\section{References (primary)}

Buble, K., \& Ljubić-Karanović, O. (1997). Pomorsko-brodogradevni englesko-brvatski i brvatskoengleski priručni rječnik. Split, Croatia: Eduka.

Luzer, J., \& Spinčić, A. (2013). Englesko-brvatski enciklopedijski brodostrojarski rječnik. Zagreb, Croatia: Školska knjiga.

Plančić, B., \& Skračić, T. (2017). Englesko-brvatski pomorski rječnik / English-Croatian Maritime Dictionary. Croatia: Faculty of Maritime Studies in Split.

Predojević, Lj. (1988). Englesko-hrvatski ili srpski pomorski poslovni rječnik. Opatija, Croatia: Otokar Keršovani.

Pritchard, B., Spinčić, A., Urbany, M., Valentić, J., Vio, D., \& Vlahović, J. (1989). Croatian or Serbian English maritime dictionary. Zagreb, Croatia: Školska knjiga.

Stazić, Ž. (2004). Englesko-brvatski rječnike pomorskih izraza i termina / English dictionary of marine words and terms. Split, Croatia: Self-published.

Urbany, M., Pritchard, B., Spinčić, A., M., Valentić, J., Vio, D., \& Vlahović, J. (1991). Croatian-English maritime dictionary / Hrvatsko-engleski rječnik pomorskog nazivilja (2nd ed.). Zagreb, Croatia: Školska knjiga.

\section{References (secondary)}

Ahmed, M. K. (2014). The ESP teacher: issues, tasks and challenges. English for Specific Purposes World, 42 (15), 1-33.

Bojović, M. (2006). Teaching foreign language for specific purposes: teacher development. Proceedings of the 31st Annual ATEE Conference, Association of Teacher Education in Europe, 487-493.

Čulić-Viskota, A., \& Kalebota, S. (2013). Maritime English - What does it communicate? Transactions on Maritime Science (ToMS), 2(2), 109-114.

Deuter, M. (2004). A tale of two halves: writing a bilingual dictionary for students of English. In G. Williams, \& S. Vassier (Eds.), Proceedings of the 11th EURALEX International Congress, 1 (pp. 245-254). Lorient: EURALEX. 
International Maritime Organization. (2001). Maritime English. Model course 3.17. London: IMO.

Lopez, S. (2006). How do you go about writing a bilingual dictionary? MED Magazine, 42. Retrieved from http://www.macmillandictionaries.com/MEDMagazine/September2006/42-Feature-Bilingual.htm

Skračić, T. (2017). Fairway - Coursebook for students of maritime English. Split, Croatia: Redak. Skračić, T. (2012). Creating an English textbook for students of maritime management. In P. Vičič, S. Orthaber, V. M. Ipavec, \& M. Zrinski (Eds.), Proceedings of the 5th International Language Conference on the Importance of Learning Professional Foreign Languages for Communication between Cultures 2012 (pp. 313-319). Celje, Slovenia: University of Maribor, Faculty of Logistics.

Vodopija, D., Skračić, T., \& Žanić-Mikuličić, J. (2017). Marine engineers' views on ESP teachers. Book of Proceedings of IMSC 2017, 7th International Maritime Science Conference (pp. 141-147). Solin, Croatia: Faculty of Maritime Studies Split. 


\title{
Preparing Language Learning Materials for Health Care Students
}

\author{
ElLE SÕRMUS, ÕIE TÄHTLA \& KATERIINA RANNULA
}

\begin{abstract}
Language learning materials must lead to automatic habits of language production and response rather than to mere knowledge about the language. Learning materials in Estonian are still lacking regarding the field of health care. Several learning materials for health care students in English have been published but these materials might not fully consider the learners sociolinguistic characteristics - since native Estonian-speakers and native Russian-speakers study in the Estonian language while sharing common classrooms, they use the same materials and need to use the same language during their studies. In the article two language acquisition materials in the field of health care are introduced: Estonian Language Grammar Course for Non-native Health Care Students and Estonian-English-Russian Online Health Care Dictionary. While preparing the materials the level of students' language skills and the most necessary grammar and vocabulary in the field of health care must be taken into account.
\end{abstract}

Keywords: $\bullet$ dictionary $\bullet$ grammar course $\bullet$ health care students $\bullet$ language learning $\bullet$ foreign languages $\bullet$

CORRESPONDENCE ADDREsS: Elle Sõrmus, MA, Lecturer-teacher, Tallinn Health Care College, Lifelong-Learning Centre, Kännu 67 Tallinn, Estonia 13418, e-mail:ellesormus@gmail.com. Ơie Tähtla, MA, lecturer-teacher, Tallinn Health Care College, Lifelong-Learning Centre, Kännu 67 Tallinn, Estonia 13418, e-mail: oietahtla@gmail.com. Kateriina Rannula, BA, lecturer-teacher, Tallinn Health Care College, Lifelong-Learning Centre, Kännu 67 Tallinn, Estonia 13418, e-mail: kateriinarannula@hotmail.com. 


\section{$1 \quad$ Introduction}

Present European context is characterized by different processes that have reshaped the ways in which we study, work and communicate. LSP (language for specific purposes) courses play an important role, integrating academic and professional communication skills with the social and critical competence that students need. Online learning appears to be especially appropriate for LSP learning because of its flexibility, absence of time and space constraints. It can also provide tuition to learners in different academic or professional situations. Harsono (2007) suggests that teachers should develop their own specific materials for their own target language learners and in developing learning materials, every teacher can follow any approach he/she is familiar with and he/she can develop his/her teaching materials by applying the principles and procedures of language teaching materials including formulating their teaching objectives and syllabus, adapting and or supplementing the existing materials, and or creating their own materials.

In the article the main theoretical viewpoints of preparing materials for ESL students are provided followed by the description of two language acquisition materials in the field of health care as well as the need for which are introduced: Estonian Language Grammar Course for Non-native Health Care Students and EstonianEnglish-Russian Online Health Care Dictionary. While preparing these materials the level of students' language skills and the most necessary grammar and vocabulary in the field of health care was taken into account.

\section{Material Preparation for ESL Students}

According to Tomlinson (1998; 2010), teaching materials should be perceived by learners as relevant and useful. Teachers can easily select materials that are relevant to the specific choice of topics and tasks that the learners are also learning in their field of study. The learners attention should also be drawn to linguistic features of the input. These linguistic features should not become the main focus in the materials but the learners should be made aware that linguistic features are needed to locate and to make a generalization about the function of the linguistic features in the main materials. The language input is contextualised. Materials should take into account that learners differ in learning styles and that learners differ in affective attitudes (Tomlinson, 1998, pp. 15-18). 
Klimova (2016) has added that materials should have a clear, concise, logical and simple structure and they should be comprehensible and up-to-date. The controlled practice appears to have little long-term effect on the accuracy with which new structures are performed and has little effect on fluency. Yet, controlled grammar practice activities still feature significantly in popular coursebooks and are considered useful by many teachers and by many learners (Ellis \& Rathbone, 1987; Harsono, 2007). Materials should provide opportunities for outcome feedback. Feedback which is focused on the effectiveness of the outcome rather than just on the accuracy of the output can lead to output becoming a profitable source of input (Harsono, 2007).

\subsection{Estonian Language Grammar Course for Non-Native Health Care Students}

According to Dalil (2013), grammar has an essential role in proficient use of the language, because it is grammar that gives the words the meaning. Grammar possesses several very different language phenomena which in some parts are similar to the learner's language and are therefore easier to acquire. Others may not bear any similarities to the learner's native language but are easy to understand, but there are some grammatical points that are completely unfamiliar and thus quite difficult to understand and use. Estonian language is a grammatical language and for successful communication grammar needs a lot of attention and learning.

In compiling the grammar course deductive grammar acquisition method has been taken as a basis, which in the end or during the learning process results in successful usage of the most complex grammar rules (Krashen, 1985). There is much regularity in the Estonian language but what makes it difficult to acquire is the partial concurrency and partial differences in the meaning and usage of the word forms. Language itself is identified by its many irregularities and a vast amount of homonymy and similarities that are not explained by the rules. In health care, it is of major importance to use grammatically correct language as misunderstandings may even have fatal consequences. Taking all before mentioned into consideration, a need to create a course Estonian Language Grammar Course for Non-native Health Care Students emerged. The course can be found in the Moodle environment, where the teacher can observe the learning 
process and give feedback if necessary. It involves basic grammar topics, which are difficult for ESL students, but essential for the health care workers. The contents of topics is also health care-related to provide the students the possibility to acquire the vocabulary needed for their future profession together with the necessary grammar knowledge. It also helps to better understand the specialty texts. All tasks in the course are self-control tests, which use the programme HotPotatoes. Learners get immediate feedback and they can redo the test as many times as they wish. In compiling the course the following types of exercises were used: fill in the gaps, matching, multiple choice, and short answers. The mentioned types were found to be the most effective types of exercises to be used in the course.

The course itself consists of 18 grammar topics and all topics follow the same structure: each topic begins with rules and examples the learners familiarize themselves with before starting the practical tasks. Each topic also includes seven exercises and each exercise consists of 14 sentences. The course has 2 tests: one in the middle of the course and a final test. It is an open-access course, which means that it is open for public use and as a result, the course has proved to be popular among the health care workers from all over Estonia. The course can be used as a part of the learning process inside the classroom, as an independent work or as a separate course conducted together with consultations.

\subsection{Estonian-English-Russian Online Health Care Dictionary}

Tallinn Health Care College has offered foreign language courses for specific purposes for more than 20 years. Several learning materials for health care students in English have been published but these materials might not fully consider the learners socio-linguistic characteristics - since native Estonianspeakers and native Russian-speakers study in Estonian language while sharing common classrooms, they use the same materials and need to use the same language during their studies. The texts the students work with are all related to the field of health care.

Derived from the fact that the College had no trilingual dictionary for various curricula and that the world is digitalizing, the idea for the development of an online health care dictionary was born. The need for dictionaries is considered essential by almost every language lecturer and emphasized by several 
professionals of the field. To use the words of Barin and Gür (2015), most language practitioners are of the opinion that dictionaries are a valuable and an indispensable tool for learning a language. Dictionaries are considered as custodians of a language and they provide students with valuable information. (Mulaudzi, 2018; Barin \& Gür, 2015). They emphasize that dictionaries are the primary reliable source which learners refer to, also, dictionaries play a crucial role in improving vocabulary knowledge (Mulaudzi, 2018; Barin \& Gür, 2015). Chan (2011, p. 1) regards dictionaries as indispensable self-learning tools.

According to the study conducted by Razak and Eswaran (2010) teachers have positive and favourable attitudes toward the use of the computers. They consider computer technology as a useful teaching tool that can enhance ways of teaching by offering students a variety of language inputs and expanding students' learning experiences in real and authentic contexts (Chan \& Son, 2009). It is also argued, that before introducing specific areas of dictionary use in the learning process, it is advisable to have a clear idea of what notions learners may have of dictionaries and how and when they think they may use them (Cubillo, 2002).

The online health care dictionary in Tallinn Health Care College has been open for public use since 2018. As Tallinn Health Care College teaches English and Russian for specific purposes, the online dictionary consists of terms in three languages: Estonian, English and Russian. The lexical items in the dictionary were chosen and entered by several language teachers. Although it seems that at the university level dictionary is a familiar tool, with which students can cope, the authors' experience is that students do not always find the words they need in their dictionaries. This problem seems to be related, first, to choosing the appropriate dictionary, and, second, to being able to interpret the information included in dictionaries (Cubillo, 2002).

Several dictionaries have been published, which include general health care terminology especially useful for nursing students. However there are a few study programmes for relatively new professions in Estonia, such as of the Optometrist, Occupational Therapist and Health Promotion Specialist. No trilingual dictionaries have been published for these professions in Estonia, and the terminology is still in the process of development. The online dictionary created by the lecturers of Tallinn Health Care College also covers the terminology of the professions mentioned above, which means that the students 
are able to find the equivalents in three languages for specific terms they would not find in a general health care dictionary published before 2018. The online health care dictionary has collected vocabulary of previously published dictionaries, yet added new terms. The dictionary will never be fully completed as the languages are constantly changing: since there will always be new materials, methods and technology, which in turn are rapidly developing in the world of health care, new vocabulary for all the health care students is being created and new terms are being translated into all languages used in the dictionary.

The terms have been selected on the basis of course materials for learning English and Russian. In Estonia's language situation, trilingual dictionary is undoubtedly better than bilingual because it gives ideas for terminology development (Erelt, 2007). Therefore the dictionary is descriptive yet inspires the terminology development. The descriptive part of the dictionary means that the new terms in the Estonian language the professionals have started to use, have been recorded in the dictionary and it should help the students to use correct terms within their professional career. When a learner is able to find an equivalent for the specific term, it improves their linguistic competence and makes them more confident.

In order the dictionary to be efficiently used in terms of the learning process it is important to know how much support is provided for the student and whether the material can be easily used by a non-native speaker (Ahmed, 2017). Materials should help learners to develop confidence and it is clear that relaxed and selfconfident learners learn faster. Many learners feel relaxed and self-confident if they think that the materials they learn are not too difficult but just one step further or more difficult than they master (Tomlinson, 1998, pp. 7-21). Although a more in-depth survey is not yet started to investigate the students' opinions and usage of the dictionary, the preliminary comments in students feedback are positive.

\section{Conclusion}

In creating the Estonian language course and online dictionary, the students best interests were taken into account but Tomlinson's (2010) viewpoints were also considered important, as it was emphasized that materials developers, who are in most cases also teachers, should reflect not only methodological principles and 
approaches, but consider that materials need to be written in such a way that the teacher can make use of them as a resource and not have to follow them as a script (Tomlinson, 2010). If such material is developed, then both teaching and learning is a challenge. Moreover, such written educational materials might increase student's interest in studies, respectively his/her motivation for selfstudy (Klimova \& Poulova, 2013). The language course is usable both independently and with a teacher thus making it universal and the language learning process motivating.

Dictionaries are an extremely important aiding tool in the learning process, which also add to the independence of the learner. By Cubillo (2002) developing this autonomy becomes a necessity, especially when the teacher is no longer present. Online trilingual dictionaries in Estonian language situation where more than one language is used in professional as well as everyday situation provide a possibility of quick language aid in situations where the usage of a word in a specific language may result in less stress and quicker problem solving. A learner needs as much information as quickly as possible and thus, dictionary usage, no matter what sort of it is, is indispensable for learners because dictionary look-up contributes language learning process substantially (Barin \& Gür, 2015).

There is an interest as well as the need to conduct further research in the field of student's opinions on the content and structure of the created materials. So far the usage of the materials and positive feedback proves their necessity but in order to better and further supplement the materials a more in-depth investigation is indicated.

\section{References}

Ahmed, S. (2017). Authentic ELT materials in the language classroom: an overview. Journal of Applied Linguistics and Language Research, 4(2), 181-202. Retrieved from https://www.researchgate.net/publication/315765820_Authentic_ELT_Materi als_in_the_Language_Classroom_An_Overview

Barin, M., \& Gür, C. (2015). Dictionary culture among students of English: a case study. Journal of Graduate School of Social Sciences, 19(1), 145-162. Retrieved from http:/ / search.ebscohost.com/login.aspx?direct=true\&db=a9h\&AN=11482698 1\&site $=$ ehost-live

Chan, A. Y. W. (2011). Bilingualised or monolingual dictionaries? Preferences and practices of advanced ESL learners in Hong Kong [Adobe Reader Version]. Journal of Language, Culture and Curriculum, 24 (1), 1-21. 
Chan, N. P., \& Jeong-Bae, S. (2009). Implementing computer-assisted language learning in the EFL Classroom: teachers' perceptions and perspectives. International Journal of Pedagogies and Learning, 5(2), 80-101. doi: 10.5172/ijpl.5.2.80

Cubillo, M. C. C. (2002). Dictionary use and dictionary needs of ESP students: an experimental approach. International Journal of Lexicography, 15(3), 206-228. doi https://doi.org/10.1093/iil/15.3.206

Dalil, Z. (2013). The importance of grammar in second language teaching. Retrieved from https://www.academia.edu/12284393/The_importance_of_grammar_in_secon d_language_teaching_and_learning

Ellis, R., \& Rathbone, M. (1987). The Acquisition of German in a Classroom Context. London: Ealing College of Higher Education.

Erelt, T. (2007).Terminiōpetus. Tartu: Tartu Ülikooli Kirjastus.

Harsono, Y. M.(2007). Developing learning materials for specific purposes. Retrieved from www.teflin.org/journal/index.php/journal/article/download/113/108

Klimova, B. (2016). Students' preferences for learning materials in technology-enchanced higher education. New Trends and Issues Proceedings in Humanities and Social Sciences, 11, 20-28. Retrieved from https://www.researchgate.net/publication/321479439_Students_preferences_f or_learning_materials_in_technology-enhanced_higher_education

Klimova, B., \& Poulova, P. (2013). ICT as an effective tool for learning English. The Third International Conference of Digital Information Processing (ICDIPC 2013), 569-573. USA The Society of Digital Information and Wireless Communications. (SDIWC).

Krashen, S. (1985). The Input Hypothesis. London: Longman.

Mulaudzi, L.M. P. (2017). Dictionary use, beliefs and students' preference: the case of ECS students at the University of Venda, South Africa. Gender \& Behaviour, 15(2), 8843-8847. Retrieved from http:/ / search.ebscohost.com/login.aspx?direct=true\&db=a9h\&AN=12615219 1\&site $=$ ehost-live

Razak, N.Z. B. A. \& Eswaran, J. A/P. (2010). Investigating the ESL teachers' attitude towards the use of computer in English language classroom. Retrieved from http://eprints.utm.my/10939/1/Investigating_The_Esl_Teachers\%E2\%80\%99 -An

d_Students $\%$ E2\%80\%99_Attitude_Towards_The_Use_Of.pdf

Tomlinson, B. (1998). Materials development in language teaching. Cambridge: Cambridge University Press.

Tomlinson, B. (2010). Principles and procedures of materials development for language learning. Retrieved from http://www.iltec.pt/pdf/Principles $\% 20$ and $\% 20$ Procedures $\% 20$ of $\% 20$ Materials $\% 20$ Development $\% 20$ Paper.pdf 


\title{
Inventive Use of Social Media in LSP Course
}

\author{
NEELAM TIKKHA
}

\begin{abstract}
People from various countries work and communicate with each other for professional reasons. There is a need to develop language which is understood between cultures. People from Business Management, Travel and Tourism and Hotel industry specially find the need to connect. Hence, it is essential for them to learn specific language acceptable between cultures. Specific language will help furthering their profession. Furthermore, people are connecting with professionals from the same field through the social media. The workshop would deal with the inventive use of social media to learn language for specific purpose on the go in inventive ways. The use of Whatsapp messenger, instagram, Cell phone Camera applications, Google translator and Google maps would be discussed to learn language for specific purpose. The workshop would be engaging and highly retentive as it would be done by forming social media groups of learners desirous to learn specific language related to their profession.
\end{abstract}

Keywords: $\bullet$ language learning on the go $\bullet$ LSP between cultures $\bullet$ smart applications $\bullet$ social media $\bullet$ specialized lexicography $\bullet$

CORRESPONDENCE ADDRESS: NeelamTikkha, PhD, Professor, RTM Nagpur University, English MMV, Amravati Rd, Ram Nagar, Nagpur, Maharashtra 440033, India, e-mail: neelam.tikkha@gmail.com 


\section{$1 \quad$ Introduction}

People from various countries work and communicate with each other for professional reasons. There is a need to develop language which is understood between cultures. People from Science, Technology, Engineering, Mathematics, Marketing, Economics, Business Management, Travel and Tourism and Hotel industry specially find the need to connect. Hence it is essential for them to learn specific language acceptable between cultures. Specific language will help furthering their profession. Learners of Language for Specific Purpose are specially adult and working class learners. The boundaries of the world have been shrinking day by day thanks to the social media. Social media has further increased the need of communicating in English. Life is so competitive that people do not have enough time for face to face communication. The demand to promote language learning as skill development which would be helpful in practical life has been increasing. LSP courses are learner centric and target at helping students apply language in day to day life. Smart phone applications, Google translator and various social media sites have developed a strong platform to learn anytime anywhere. Carefully designed LSP courses place learners in the real world situation and help to link language learning output with other disciplines like "STEM [science, technology, engineering, mathematics]" (Crouse, 2013) . It also helps to utilise the skill to "navigate culture in the context of a specific field. In the critically important field of STEM [science, technology, engineering, mathematics], for example, more and more people are discovering ways to connect related professions with language learning." This paper discusses the use of social media to learn language on the go in an inventive way.

Literature review: The Colorado Congress of Foreign Language Teachers (CCFLT) says "Students are more willing to work hard at something when they see those connections outside the four walls of the classroom. They want to be able to take what they learn in school and apply it to real life." The ultimate expression of the Connections goal area of the National Standards for Learning Languages (i.e., "Connect with Other Disciplines and Acquire Information") (Crouse, 2013).

Ann M. Johns and Tony Dudley-Evans define ESP and examine its distinguishing features. The international nature and scope of the movement are particularly emphasized. Finally, questions and controversies surrounding the movement are discussed (Johns, 1991). 
Fuertes discusses the leading role that English philologists are called to play in the analysis of specialized communication. Considering that University Degrees are being adapted to accommodate to Bologna guidelines, English philologists, for example, could incorporate into their more traditional fields of research new analyses of special communication, particularly those focused on specialized lexicography and English for Specific Purposes (ESP). With respect to specialized lexicography, the recent publication of the Dictionnaire dápprentissage du français des affaires (DAFA) offers interesting insights as to how the works of pedagogical lexicographers suit the needs of specialists, wouldbe specialists, and the informed layperson. Regarding ESP, two assumptions merit further interest. On the one hand, disciplinary variation is significant, thus paving the way for more incisive and rather different genre analyses. On the other hand, research with special purpose corpora encourages us to think that the tenets of, for example, Discourse Analysis, can be used to investigate the role played by ideology in specialized communication (Fuertes, 2005).

\section{Justification}

International collaborations in Science, Technology, Mathematics and Engineering is growing day by day. Communication between cultures has become very important. One must develop global fluency so that different culture and time zones are brought in the loop.

Need for Global Fluency and Social Media: Crouse says, "global fluency is the ability to understand and collaborate across the complexities of language, culture, and multiple time zones". He urges students to view all subjects "in a global context" and cautions them that using Internet-rendered translations isn't enough. "If you rely on Google Translate, you may be surprised, confused, or embarrassed," he says. He advises exploring 'talking dictionary' and online translation tools (Crouse, 2013).

Social media is an effective platform for informal learning. One can form Whatsap groups and post queries. People who know the answers can post the answers. Learning on social media is great fun. It is also useful since language is used outside the four walls of the classroom. 
One can circulate videos that would be highly useful in learning language. Further, learners can share anecdotes and jokes. There are also apps like Cambridge Grammar App, British Council Grammar App duolingo smart applications which help learn language effectively.

Young generation is very fond of posting selfies on the social media sites. Every social site has selfies of Bollywood stars and top leaders. Snapchat is a social mobile messaging application. One can share photos, videos, text, and drawings. It is free to download. It has become hugely popular in a very short space of time, especially with young people. It has a unique feature that differentiates it from other applications: the messages disappear from the recipient's phone after a few seconds. It has a total of 187 million daily active users. Snapchat a photo based message system processes a number of messages in a day's time. Young Gen usually prefers to share Selfies. Selfies have been entertaining people by providing them an idea and a space to tell stories about themselves to each other, holding up a mirror to see reflections of irony and beauty, and all sorts of speckles in the kaleidoscope of one's cultural character.

\section{$3 \quad$ Methodology}

Language learners can circulate their selfies on snap chat, Instagram or WhatsApp. The selfies serve as a catalyst for writing and discussion. This helps to compare what they think about themselves and how others think about them. 


\section{$4 \quad$ Technique I}

\subsection{Selfie- Life}

Selfie was taken by a girl called Mehvash (refer Fig 1)and given below is her description of it:

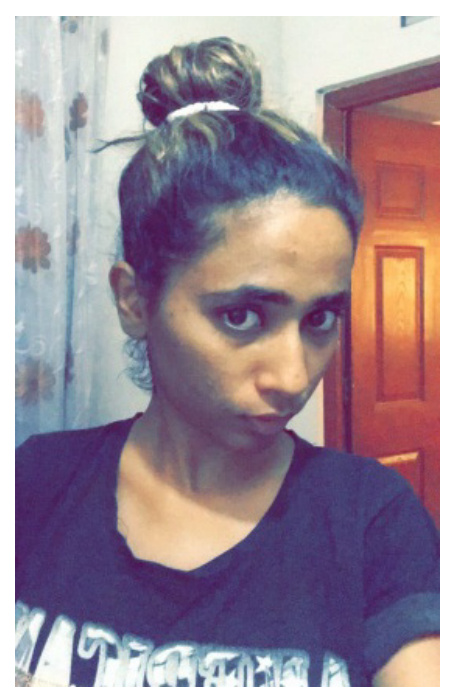

Figure 1: SelfieMehvash

(c) Dr. N. Tikkha

Hi this is Mehveash's selfie taken on $16^{\text {th }}$ April , 2017, around $10.51 \mathrm{am}$.

$\mathrm{I}$ am wearing a blue $\mathrm{T}$ - shirt / top in this selfie .

I have my hair tied in a bun .

I can see my birth mark on my neck in this selfie .

I embrace my birthmark as it has become a part of my identity.

I have curly hair and this is the reason I always prefer to tie my hair in a bun.

I am of Indian ethnic background and have brown skin with black eyes.

I have colored my hair which gives me an ombre look. 


\subsection{Cross Selfie}

A student in the workshop, called Hussain was asked to describe Mehvash. Hussain's description of Mahvesh's selfie. He titles it as Ombre Selfie.

\section{OMBRE Selfie}

Mehvash's eyes look passionate.

Her hair is well combed and she looks pretty in western clothes. The picture has been captured in low light. She resembles film star Madhubala. According to me she has bold yet sober looks. Her body language makes her look quite mature in this selfie

\subsection{Hussain's Selfie}

Similarly other participant has described his selfie.

\section{Comparative discussion}

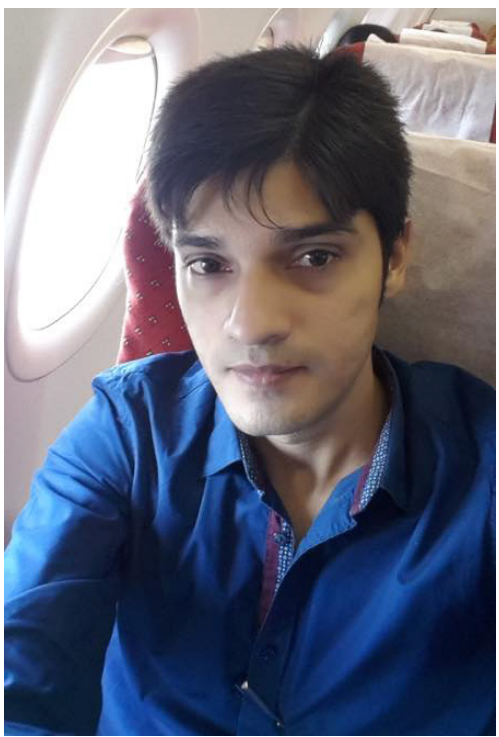

Figure 2: Selfie Hussain 
This is Hussain's selfie - taken on a plane.

I am in a happy and relaxed mood.

My face looks glowing and eyes sparkling.

My hair style is Bollywood style.

I am wearing a nice party blue $\mathrm{T}$ - shirt.

The shirt suits me the best of all of my collection.

The expressions captured in selfie show confidence and make me look perfect.

The photo was taken when I was going abroad.

I was very happy and was having great fun.

\section{$5 \quad$ Technique II}

\section{Writing Diary}

Further, WhatsApp messenger, Snapchat and Instgramcan be used to share diary entries. Given below is an interesting example of a diary entry by a participant of the workshop. She narrates a real life incident of her life. Writing diary can be a very engaging exercise.

Dear Diary, To Dear God,

I was on my very enjoyable morning to my college after weekend visit home at Nagpur. I decided to go by train. I reached the station to catch the Geetanjali Express to Wardha. When the train arrived it was full. I had no option but to catch the train since, I had to fill in my exam form on that day. So I jumped in, but out of a sudden like God Bless India, did she have strength. I mean it was like Spartaall over again, with her knocking me into some unforeseen doom. She pushed me so hard that my $55^{\prime} 5^{\prime \prime}$ bag of bones took off. I failed to comprehend what was going on. Next thing I knew was I was holding the pole. The train pushed off with a mighty speed and I still swinging on the pole. Thepole my savior, my mind started wandering what if I lose grip on the pole and fall down.

Who would tell my parents. How would my mom and dad feel when they hear of my death. I started sweating and shivering with fear imagining the reaction of my parents and siblings when they would hear about my death. Suddenly, I felt a strong hand pulling me inside the train. Oh, God thank you for giving me another chance to live. 


\section{Nalini Rai}

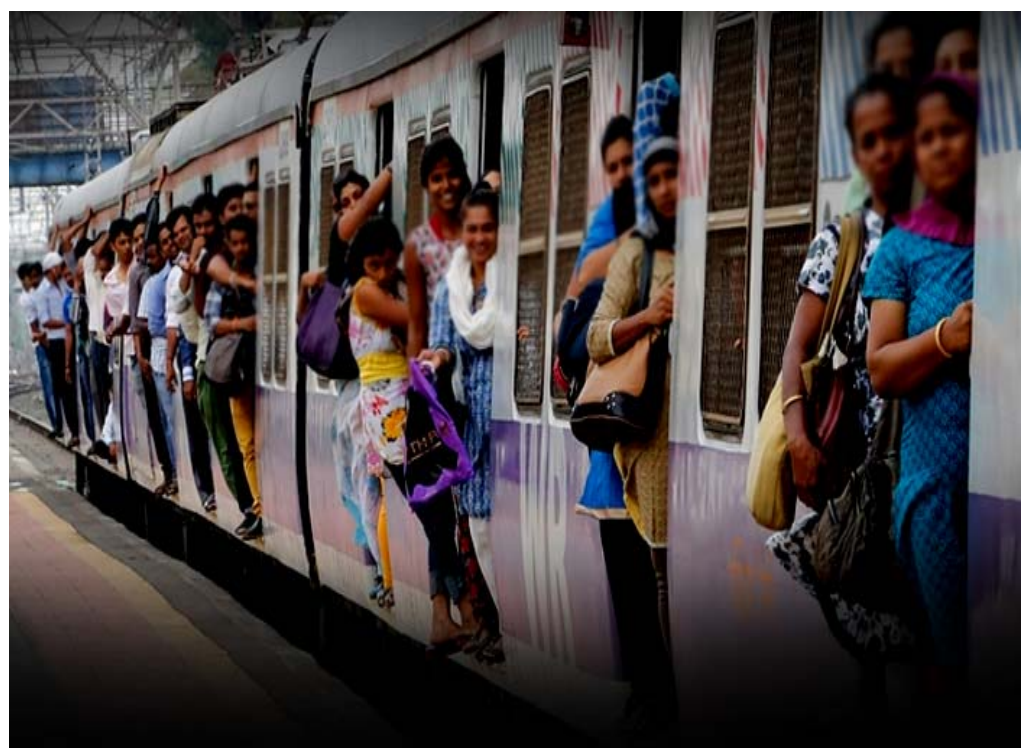

Figure 3: Press Trust of India (2012, February 27)

\section{6}

Technique III

\section{Funny Images}

Using funny photographs which are circulated on Whatsapp groups. Students are asked to describe funny photographs that they have received throughout the day on whatsapp.

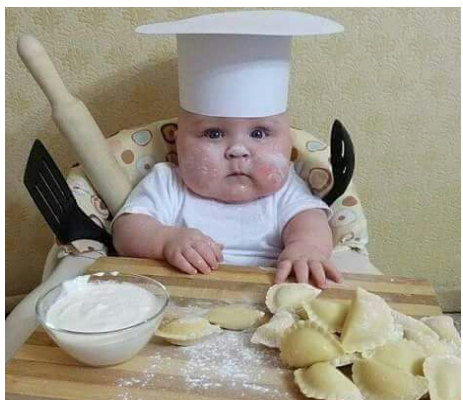

Figure 4: N. Tikkha (personal Whatsapp communication, January 19, 2017) 
A participant's description of the above image is given below:

The cook in the image is very cute. He is dressed cutely. He appears to be a stuffed dumpling. The dish he is making I think he would eat it all himself, since he is a chubby fat cook.

The idea is to circulate photographs that would trigger off some discussions.

\section{$7 \quad$ Technique IV}

\section{Anecdote sharing}

Each participant of the workshop is asked to share an anecdote, or a joke daily in direct narration. The learners should add some lies to the narration. The other participants need to identify the lies which the person is narrating. It will be an engaging exercise. It will also help to improve conversational English since direct narration will be used.

\section{Technique V}

\section{Dialogue Writing}

Learners can write a dialogue and post it in the learners group, through social media. Another person should add one dialogue and thus a chain of dialogues will help form a long conversation. 


\section{Technique VI}

\section{Describing working of objects}

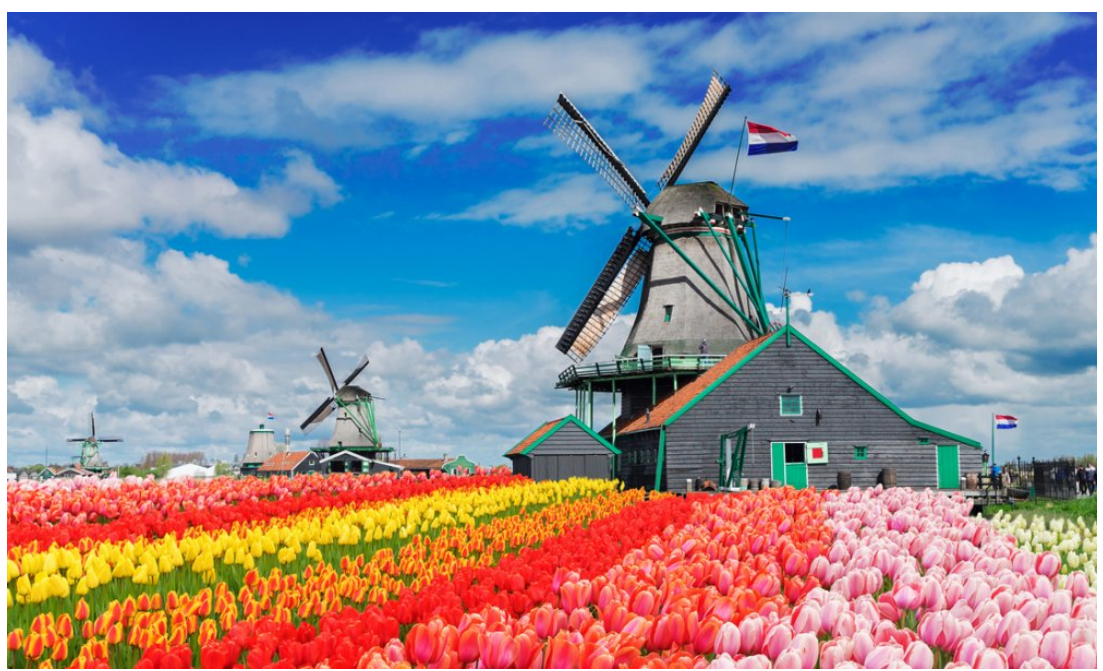

Figure 5: Expat. Windmills in the Netherlands ( 2019, January, 9)

A learner can send an image of the equipment used by him in his field in the group and then each can describe what they see. For example describing working of a windmill.

\section{Wind Mill}

Wind mill uses kinetic energy to generate electricity. It is used to grind flour from corn. In order to do this, the wind would have to prompt the sails to turn. Today, these windmills are called wind turbines. The wind mill converts energy of wind into rotational energy by the help of blades. 


\section{Use of Google Applications}

\subsection{Google Maps}

Another, highly useful and practical application of Google map can be helpful in learning language. Participants are asked to converse in pairs. Given below is an example of a conversation with a foreigner on airplane.

\section{Conversation with a foreigner on the flight to Dallas from Washington DC} America

Neel: Can you please tell me where you are from?

Hena: I am from Plano. It is a city in the state of Texas. The city Dallas is part of Dallas Fort Worth Metropolitan Area. And where are you from?

Neel: I am from India.

Hena: Where in India do you live?

Neel: I live in Nagpur. Please wait I'll show you on the Google map my address of the house and part time work place.

Hena: Oh! Confidence Spoken English Classes - a nice name.

NEEL: Thank you very much.

You are welcome to India. I have given you directions to my house. Please do come.

Hena: Is there any public transport like metro.

Neel: I am sorry metro is under construction for that you will have to wait until 2021. Ola and Uber cabs or auto rickshaw is a good option. You can take prepaid cab from inside the airport itself but it would cost you more than Ola and Uber. If you have more luggage I would suggest prepaid cab since it picks you from the exit itself, for Ola or Uber you have to walk for a while and pay around 1 dollar parking charges. 


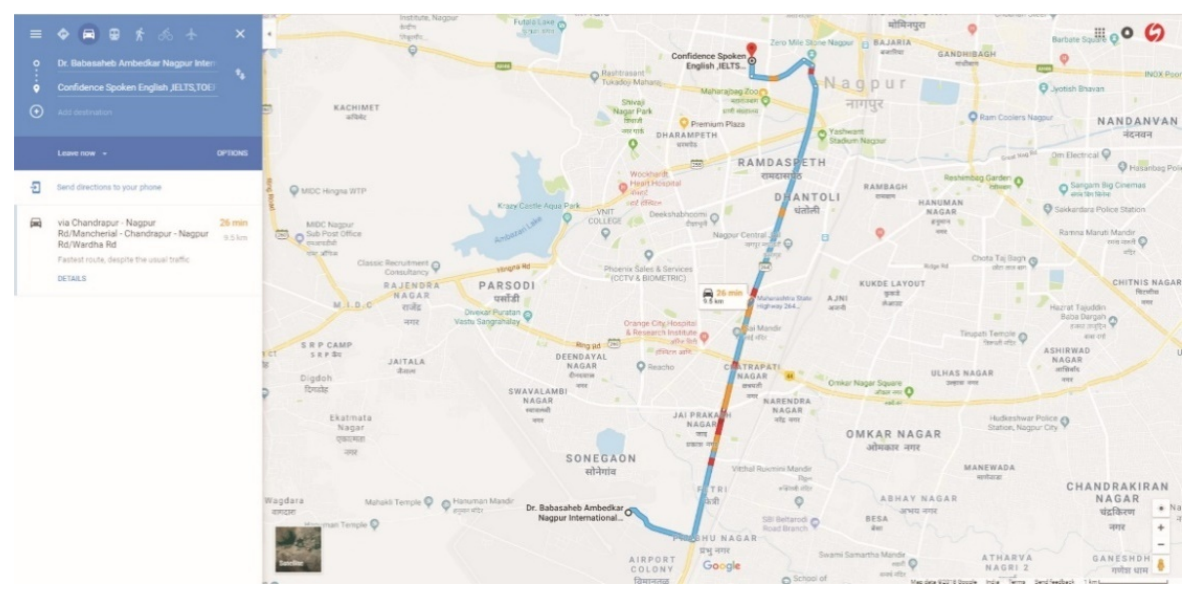

Figure 6: N. Tikkha, personal photograph, May 2, 2018.

\subsection{Google translator}

Use of Google translators can also be very effective in learning English Language. Participants can be asked to make conversations as given below:

\section{Conversation with a Foreigner in a hotel}

Neel: Could you please tell me where can I buy Shooting glasses in Frankfurt. Amy: You can buy online or from weapon shop.

Neel: I'll be leaving soon to India so I can't buy online. I tried searching for weapon shop on Google map but did not find any.

Amy: Oh! You need to type in German "Waffenladen"for weapon shop.

Neel: Can you also tell me what the German word for body lotion, hand wash and hand conditioner is? My daughter wants it.

Amy: Body lotion is - Körperlotion, hand washis called— Handwäsche and hair conditioner is Haarspülung.

Neel: Can you pleasetell me things to do in Frankfurt?

Amy: Michael is from Frankfurt you can ask him.

Michael: You can go to Palmengarten, Museumsufer,Senckenberg Natural History Museum (NaturmuseumSenckenberg),German Film Museum (DeutschesFilmmuseum), Rhine Valley, Black forest, Open Opera and Zoo.

Neel: What is there to see in Palmgarten? 
Michael: It is a botanical garden with fountains and there is an interesting celebration of October Fest going on now. UNICEF has organized workshops for carving pumpkins and making tree houses for small children.

Neel: Sure, I would love to go there. How do we say- "turn to your right" and "turn to your left"?

Michael: It is "nachrechtsabbiegen" and "nach links abbiegen".

Neel: Please also tell me what is the German word for Airport and terminal 1. I am flying to India from Frankfurt airport.

Michael: I suggest you use Google translator. It is a very handy tool. It also has voice translator. So you can communicate in German.

Neel: Does it translate accurately?

Michael: No, not really. But, it is practical and you would be able to communicate efficiently. By the way, airport is called - Flughafen. Even if you say terminal 1 people would understand.

Neel: Thank you very much. Your suggestions have changed nightmare to sweet dreams.

Learners find using Google map and Google translator applications handy and of practical utility and hence try to learn language through such exercises keenly.

\section{Technique IX}

\section{Writing for e-blurbs and advertisements}

Students should be taught to practice writing e-blurbs and advertisement writing. A person can generate revenue by writing e-blurbs. Advertisement writing is useful to promote products online and any enterprise a student wants to start. Writing e-blurbs and advertisements can be helpful in self-employment too.

\section{Conclusion}

To conclude, social media can be effectively used to learn language for specific purposes. Group learning on social media is an impressive way to learn language. Whatsapp, Snapchat, Instagram, Youtube and various Google Applications happen to be very effective media. These applications save time and moreover there is no barrier of place and can be learnt whenever or wherever the learner finds it convenient and has enough time to spare. These exercises are interesting and thus render learning stress free and effortless though being highly efficient 
method of learning. The learning output is also very high. These applications can be used by learners of any age group for learning English language for specific purpose.

\section{Acknowledgments}

I acknowledge my gratitude to Dr. S. N. Buhariwala for her valuable feedback in writing this article and all participants of the workshop.

\section{References}

Crouse, D. (2013, April). Languages for specific purposes in the 21 st century. The Language Educator, 32-35.

Fuertes, O. P. (2005). Specialized communication and English studies: research proposals on specialized lexicography and English for specific purposes. Atlantis, 27(2), 4155.

Johns, A. M., \& Dudley-Evans, T. (1991). English for Specific Purposes: International in scope, specific in purpose. TESOL Quarterly, 25, 297-314.

Press Trust of India. (2012, February 27). Youth dies after falling from local train in Mumbai. Retrieved January 9, 2019, from https:/ / www.india.com/news/india/youth-diesafter-falling-from-local-train-in mumbai

Expat. (n.d.). Windmills in the Netherlands. Retrieved January 9, 2019, from https://www.iamexpat.nl/lifestyle/sightseeing-attractions-netherlands/dutchwindmills 


\title{
Unterscheiden sich slowenische und deutsche Manager voneinander?
}

\author{
SILVIJA TINTOR
}

\begin{abstract}
Zusammenfassung Wir sind uns der Bedeutung von Fremdsprachenkenntnissen bewusst, wenn wir ausländische Investoren für slowenische Unternehmen gewinnen wollen oder wenn wir erfolgreich mit ausländischen Märkten zusammenarbeiten wollen. Unternehmen und Geschäftsleute, die sich dieser Tatsache bewusst sind, sind bereit, in sich selbst und ihre Kollegen zu investieren und organisieren daher verschiedene Formen von zusätzlicher Bildung im Bereich des Fremdsprachenlernens. Es gibt eine wachsende Zahl von Unternehmen, die mit den deutschsprachigen Ländern zusammenarbeiten und wissen, dass Deutschkenntnisse noch mehr Möglichkeiten zur Zusammenarbeit mit diesen Märkten eröffnen. Neben den Sprachkenntnissen ist das Wissen über interkulturelle Unterschiede oft der Schlüssel zum Abschluss von Geschäften ist. Es sind Situationen, in denen wir trotz der ausgezeichneten Sprachkenntnisse einen Fehler im Bereich der nonverbalen Kommunikation machen und die Geschäftspartner falsch bewerten oder verstehen.
\end{abstract}

Schlüsselwörter: • Fremdsprachenkenntnisse $\bullet$ Auslandsmärkte $\bullet$ interkulturell $\bullet$ nonverbal $\bullet$ Geschäfte $\bullet$

ÜBer DEN AUTORIn: Silvija Tintor, Wirtschaftsschule Celje, Höhere Berufsschule, Mariborska 2, 3000 Celje, Slowenien, E-Mail: silvija.tintor@gmail.com. 


\section{$1 \quad$ Einleitung}

Einstellungen und Werte sind die Grundlage der Kultur jedes Landes und sind die Bausteine für die Entwicklung der Unternehmenskultur. Kulturelle Einflüsse, Einstellungen und Verhaltensweisen variieren innerhalb und zwischen Nationen sowie innerhalb und über ethnische Gruppen hinweg und sind stark in Gemeinschaften eingebettet.

Ein besonderer Schwerpunkt liegt auf der Vermittlung von interkulturellen Unterschieden, der Anerkennung von Stereotypen und dem Umgang mit ihnen, sowie der Bedeutung der nonverbalen Kommunikation. Ob, und wenn ja, in welchem Ausmaß unterscheiden sich die slowenischen und die deutschsprachigen Geschäftsleute? Inwieweit sollten sie angepasst werden? Ist es wichtiger, Deutsch zu sprechen oder Geschäftspartner zu kennen? Wie bringt man den Studenten bei, Geschäftspartner besser zu verstehen?

Geschäftsleute, die von ihren Reisen in Europa profitieren möchten, sollten sich über die Kultur und Bräuche der Länder informieren, die sie besuchen möchten. Flexibilität und kulturelle Anpassung sollten die Leitprinzipien für die Geschäftstätigkeit in diesem Land sein. Geschäftsmanieren und -methoden, religiöse Bräuche, soziale Verantwortung von Unternehmen werden in den folgenden Abschnitten behandelt. Zu den kulturellen Unterschieden, mit denen Geschäftsleute am häufigsten konfrontiert sind, gehören Unterschiede in den Geschäftsstilen, die Einstellung gegenüber der Entwicklung von Geschäftsbeziehungen, die Einstellung zur Pünktlichkeit und die Geschenkbräuche.

\section{Wie sind slowenische Geschäftsleute?}

Slowenen sind daran interessiert, vernetzt zu sein und sich in das internationale Geschäftsumfeld zu integrieren. Das höchste Anliegen ist die Qualität von Produkten und Dienstleistungen. Unternehmen verfolgen Strategien mit hohen Standards und konzentrieren sich auf das Interesse der Marktsegmente an Hochtechnologie.

Sie sind offen dafür, bewährte Verfahren von anderen zu "importieren", insbesondere von Ausländern mit früheren Erfahrungen. Die Geschäftskultur 
anderer Länder ist ebenfalls ein Thema von Interesse, da sie auch daran interessiert sind, ihre Produkte, Dienstleistungen und ihr Wissen zu "exportieren".

$\mathrm{Zu}$ den sicheren Diskussionsthemen gehört, dass Sie Ihre Erfahrung mit dem Besuch Sloweniens in Bezug auf Landschaft, Kultur und Sport würdigen. Slowenien hat eine sehr schöne Landschaft und es könnte sinnvoll sein, sich zu fragen, was Sie sehen und tun sollten, wenn Sie während Ihres Besuchs Zeit haben.

$\mathrm{Zu}$ den Themen, die vermieden werden sollten, gehören jegliche Vergleiche zwischen Slowenien und anderen Ländern des ehemaligen Jugoslawiens sowie jegliche Bezugnahme auf den Zweiten Weltkrieg. Außerdem sollte Sloweniens Position in Europa immer als mitteleuropäisch bezeichnet werden.

Es ist keine gute Idee, andere Geschäftspartner vor Ihrem slowenischen Partner offen zu kritisieren, und die slowenische Geschäftspraxis rät, dass Sie keine diffamierenden Aussagen über Ihre Mitbewerber machen sollten.

In Slowenien ist es ratsam, Geschäfte mit Vergnügen nicht zu vermischen. Insbesondere sollten Sie es vermeiden, nach intimen persönlichen oder vertraulichen Themen zu fragen, insbesondere nach Fragen zu den persönlichen Finanzen Ihres Gastgebers.

Slowenen bevorzugen eine persönliche Kommunikation mit einem potenziellen Geschäftspartner, was ihnen die Möglichkeit gibt, jemanden persönlich zu treffen, um ihnen in die Augen zu schauen und ein gewisses $\mathrm{Maß}$ an Vertrauenswürdigkeit zu gewinnen. Nonverbale Kommunikation ist in diesem Teil der Welt lebenswichtig; indirekter Blickkontakt wird als Desinteresse gewertet und als Versuch, etwas $\mathrm{zu}$ verbergen. Insgesamt sind die Einstellungen zu Unternehmen und Professionalität in Slowenien denen von Deutschland und Österreich sehr ähnlich.

Während des ersten Treffens werden sich die Geschäftspartner eng an die formellen Regeln des Protokolls und der Verfahren halten, aber wenn sich eine Beziehung entwickelt, werden die Treffen nach und nach informeller. 
Da die slowenische Gesellschaft in ihrer Geschäftsauffassung eher formal ist, ist es ratsam, einen formelleren Stil anzunehmen und darauf zu warten, dass sich die Beziehung zu einer Freundschaft entwickelt, bevor man zu viel Vertrautheit in der Konversation zulässt.

Die slowenische Sprache unterscheidet zwischen dem Singular, dem vertrauten "Sie" und der pluralen, höflichen "Sie" -Form der Adressierung von Menschen. Es ist wichtig $\mathrm{zu}$ beachten, dass es nicht automatisch bedeutet, dass die Beziehung zu einer Freundschaft geführt hat. Daher sollten Sie immer die höfliche Form der Adresse verwenden, bis Sie von Ihrem Geschäftspartner dazu aufgefordert werden, sie mit vertrauteren Begriffen anzugehen. Die Geschäftsbeziehungen in Slowenien sind ebenso wie in vielen anderen Ländern der Welt darauf angewiesen, persönliche Kontakte zu knüpfen und Zeit zu investieren, um Vertrauen aufzubauen und einander kennenzulernen.

Der erste Kontakt mit einem potenziellen Partner in Slowenien erfolgt normalerweise per Fax oder E-Mail und sollte mit einem Brief verfolgt werden. Wenn sie an einer Geschäftsbeziehung interessiert sind, antworten sie normalerweise innerhalb kurzer Zeit. Sobald eine Beziehung hergestellt ist, ist es leicht, zu einer mündlichen Vereinbarung zu kommen, die dann schriftlich festgelegt und bestätigt werden sollte. Schriftliche Vereinbarungen sind wichtig, um sicherzustellen, dass alle Parteien ein klares Verständnis davon haben, was vereinbart wurde, was von ihnen erwartet wird, und klarstellen, welche spezifischen Bedingungen möglicherweise gelten. Durch die schriftliche Verteilung der Vereinbarung erhalten die Teilnehmer außerdem die Möglichkeit, Fehlinterpretationen zu korrigieren und Problembereiche anzusprechen.

Es wird empfohlen, dass ausländische Geschäftspartner ihren ersten Kontakt in schriftlicher Form, per Brief, E-Mail oder Fax eingehen. Die Kommunikation sollte direkt an eine bestimmte Person gerichtet werden, die in der Lage ist, eine schnelle Entscheidung zu treffen, wie zum Beispiel der Geschäftsführer. Wenn die Person, mit der Sie in Kontakt stehen, Englisch spricht, dann ist die beste und schnellste Art der Kommunikation die direkte Kontaktaufnahme per Telefon. 
Es ist auch nützlich, sich mit Vertretern der slowenischen Unternehmen zu treffen, indem Sie an relevanten Messen, Seminaren und Konferenzen in Slowenien und im Ausland teilnehmen.

In der slowenischen Wirtschaft neigen Leute dazu, Titel mit Nachnamen zu verwenden, wenn sie sich gegenseitig ansprechen. Im Gespräch werden Titel entsprechend der Ausbildung oder der Position der Person im Unternehmen verwendet. Nach Abschluss der Universität kann eine Person den Titel "Diplomiran" oder "Master" verwenden, je nachdem, welches Studienniveau sie erreicht haben. Nach Abschluss der Promotion würde eine Person normalerweise den Titel "Doktor" oder "Professor" verwenden, wenn sie ihre Qualifikation nutzen, um in einer akademischen Einrichtung zu unterrichten. Daher kann eine Person unabhängig vom Geschlecht als "Doktor Golob" oder "Professor Znanosti" angesprochen werden.

Die Verwendung von akademischen Titeln im geschäftlichen Umfeld, wie zum Beispiel Professor (Prof.) oder Doktor der Medizin (Doktor Kocjan - PhD), erhöht den Respekt vor der Person, insbesondere bei der älteren Generation. Wenn Sie jemanden ansprechen, haben die auf der Visitenkarte genannten akademischen Titel Vorrang vor Geschäftstiteln. Wenn eine Person keine akademischen Titel auf ihrer Visitenkarte angibt, kann es angebracht sein, sie anhand ihrer Position im Unternehmen anzusprechen.

\subsection{Geschäftstreffen in Slowenien}

Slowenen nehmen das Geschäftstreffen sehr ernst und bereiten es sorgfältig vor. Sie erwarten von dem Partner, dass er bereit ist, die Produkte, Dienstleistungen und den Vorschlag zu präsentieren und auf weitere Fragen antworten zu können.

Die Hierarchie ist ein wesentlicher Teil der slowenischen Geschäftswelt und das Bildungsniveau und die Erfahrung einer Person sind wichtig für ihren Status und ihre Karriereentwicklung. Bei einem ersten Treffen tauschen die Slowenen traditionell Visitenkarten aus. Sie sollten sicherstellen, dass Ihre Karte Ihre akademischen Titel und Position bei der Arbeit enthält, um sich richtig vorzustellen. 
In der Regel wird ein erstes Treffen nicht einer festgelegten Agenda folgen, sondern als allgemeine Einführung dienen, so dass sich beide Parteien gegenseitig kennen lernen und feststellen können, ob genügend Potenzial für eine nützliche Zusammenarbeit besteht.

Es dauert in der Regel mehrere Treffen, bevor eine Einigung erzielt werden kann, da die meisten slowenischen Unternehmen hierarchisch organisiert sind und das oberste Management die wichtigsten Entscheidungen trifft. Entscheidungsbefugnis wird selten an jemanden unter der Führungsebene delegiert, und Familienunternehmen sind die an der schnellsten wachsenden Art von Unternehmen.

Wenn Sie ein Treffen vorschlagen, müssen Sie Ihrem slowenischen Partner mehrere Termine angeben, aus denen Sie auswählen können, welche Gründe Sie für die Einladung benötigen, und angeben, an wem Sie am Meeting teilnehmen möchten. Die Monate Juli und August sollten vermieden werden, da die meisten Slowenen hier ihre Sommerferien verbringen und Unternehmen geschlossen werden oder mit einem reduzierten Personalbestand arbeiten. Wenn Sie nach einer schnellen Entscheidung suchen, ist es ratsam, wichtige Entscheidungsträger in Ihre Einladung aufzunehmen und sicherzustellen, dass ein gleichrangiger Vertreter Ihre Firma in der Besprechung vertritt. Es wird erwartet, dass Sie in der Lage sein werden, eine Liste Ihrer Unternehmensvertreter, einschließlich ihrer Berufsbezeichnungen und einer kurzen Biographie jeder Person, bereitzustellen, damit das slowenische Unternehmen geeignete Teilnehmer einladen kann.

Versuchen Sie möglichst eine schriftliche Bestätigung der genauen Uhrzeit und des Ortes des Treffens zusammen mit einer Liste der slowenischen Vertreter zu erhalten.

Die beste Zeit für ein Geschäftstreffen ist zwischen 9:00 und 12:00 Uhr, da das Mittagessen normalerweise zwischen 12:00 und 15:00 Uhr eingenommen wird. Slowenen können alternativ ein "spätes Mittagessen" zwischen 15.00 und 17.00 Uhr haben. Der Gastgeber des Meetings ist in der Regel für die Reservierung des Veranstaltungsortes verantwortlich, einschließlich der Anordnung der erforderlichen Ausrüstung, Einrichtungen und Erfrischungen. Es empfiehlt sich, vorher die Sprache des Treffens zu vereinbaren und gegebenenfalls mit dem Gastgeber einen Dolmetscher zu beauftragen. Wenn Sie einen Dolmetscher verwenden, ist es sinnvoll, ihnen im Vorfeld Kopien der 
Präsentation und der unterstützenden Dokumentation zur Verfügung zu stellen, um sich mit dem Thema vertraut zu machen.

Für die meisten Geschäftstreffen ist es hilfreich, Marketingmaterialien, Produktproben und unterstützende Dokumente mit Ihrem Gastgeber zu bringen.

In Slowenien ist das Geschäft stark reguliert, und die Unternehmen müssen wie auch immer - für jede wichtige Entscheidung und jeden Vertrag eine Genehmigung der lokalen Behörden erhalten. Ausländische Unternehmen finden es oft wichtig, einen Slowenen in einer Managementposition zu beschäftigen, obwohl das Netzwerk von lokalen Agenten, Beratern, Beratern und Rechtsanwälten, die bereit sind, für ausländische Unternehmen zu handeln, gut entwickelt ist.

\subsection{Verbale Kommunikation}

Verhandlungen in Slowenien sind ein bisschen Geben und Nehmen. Um eine Win-Win-Situation zu erreichen, zeigen Sie den Slowenen ihre persönlichen und geschäftlichen Vorteile, damit das Geschäft große Erfolgschancen hat.

Bei den Verhandlungen nehmen Senior Manager der älteren Generation in der Regel ihre Zeit in Anspruch, bevor sie zu einer Entscheidung kommen. Außerdem mögen sie es nicht, gehetzt $\mathrm{zu}$ werden und aggressives Verhandlungsverhalten zu übelnehmen; Sie neigen auch dazu, mit jemandem in ihrer eigenen Altersgruppe zu sprechen. Obwohl sie nicht emotional verbunden sind, werden sie sich bemühen, eine freundliche Atmosphäre zu schaffen und versuchen, humorvoll zu sein.

Manager der jüngeren Generation sind stärker verwestlicht, da viele für ihr postgraduales Studium in Westeuropa oder Amerika studiert haben und ihr Verhandlungsstil eher amerikanisch als slowenisch ist.

Bei einer Präsentation ist es wichtig sicherzustellen, dass alle Nachforschungen durchgeführt wurden, um ein stichhaltiges und überzeugendes Argument zu liefern, das gute Gründe für die Beteiligung Sloweniens bietet. Ein Schlüsselproblem wird der Nutzen der Partnerschaft für das Gastunternehmen sein. Um ihre Reputation zu untermauern, werden die Slowenen eine Liste von 
Referenzen ihrer Geschäftspartner vorlegen und erwarten, dass Sie, wenn möglich, mit Referenzen von Ihren eigenen Partnern revanchieren.

Verhandlungen mit dem öffentlichen Sektor dauern in der Regel länger als mit dem privaten Sektor, und andere Schlüsselfaktoren beim Abschluss von Geschäftsabschlüssen sind die Qualität von Produkten oder Dienstleistungen und die Flexibilität, über Preise zu verhandeln.

Sobald eine mündliche Einigung erzielt wurde, werden die Slowenen erwarten, dass ein schriftlicher Vertrag mit den vollständigen Bedingungen ausgearbeitet wird, um die Vereinbarung zu treffen.

\subsection{Nonverbale Kommunikation}

Wenn Sie Ihre Geschäftspartner grüßen, sollten Sie direkten Blickkontakt halten, einen festen Händedruck geben und Ihren Namen deutlich angeben, bevor Sie Ihre Visitenkarte offen anbieten. Direkter Blickkontakt und Lächeln sind wichtig, um Aufrichtigkeit und Vertrauenswürdigkeit zu vermitteln. Es ist üblich, allen Teilnehmern bei der Ankunft und am Ende eines Treffens die Hand zu geben, zuerst die Frauen und dann die Männer zu begrüßen.

Da die Slowenen keine enge Kontaktkultur haben, ist es gut, daran zu denken, einen gemäßigten zwischenmenschlichen Abstand (1 bis 1,5 m) zu halten und übermäßig vertraute Gesten wie Umarmen, Küssen oder Ohrfeigen auf dem Rücken zu vermeiden.

Wenn Sie eingeführt werden, sollten Sie sich an Personen mit ihren offiziellen Titeln und Familiennamen wenden, die Wertschätzung und Respekt für ihren Status zeigen. Das Formalitätsniveau sollte zunächst sehr hoch sein und Sie sollten darauf warten, dass Ihr Partner informelle Ausdrücke vorschlägt oder Sie auffordert, sie mit ihrem Vornamen anzusprechen. Der Vorname ist ein Hinweis darauf, dass sich die Geschäftsbeziehung zu einer vertrauteren Ebene entwickelt hat. 
Für die Slowenen ist es wichtig, eine persönliche Beziehung aufzubauen, bevor sie über Geschäfte sprechen. Die Person, die den Vorsitz führt, wird mit ziemlicher Sicherheit der höchste Vertreter des slowenischen Unternehmens sein, und sie wird das Tempo des Treffens und der Gesamtverhandlungen festlegen. Während dieser Treffen werden Kaffee, Saft und manchmal ein Sandwich oder Buffet angeboten.

Wenn Sie nach einem Meeting zum Abendessen oder zu einem Drink eingeladen werden, sollten Sie dies akzeptieren. Soziale Anlässe dienen dazu, persönliche Beziehungen aufzubauen und helfen, eine bessere Grundlage für die Entwicklung von Geschäftsbeziehungen zu schaffen.

Der Gastgeber bereitet in der Regel das Sitzungsprotokoll vor, in dem die wichtigsten Punkte der Diskussion zusammengefasst, die allgemeinen Schlussfolgerungen dargelegt und eine detaillierte Liste der Aktionspunkte und Daten angegeben werden, bis zu denen sie ausgefüllt werden sollten. Das Protokoll wird normalerweise innerhalb weniger Tage nach dem Treffen verteilt, so dass die Sitzungsteilnehmer die Möglichkeit haben, sich zu äußern und Änderungen zu berücksichtigen, bevor eine förmliche Vereinbarung abgeschlossen wird.

Wenn vereinbart wurde, die Partnerschaft fortzuführen, wird ein Zeitplan erstellt, der die Verantwortlichkeiten beider Geschäftspartner aufzeigt, einschließlich fester Termine, Termine und Orte zukünftiger Treffen usw.

Wenn einer der Partner seine zukünftige Zusammenarbeit nicht als vorteilhaft erachtet, steht es ihm frei, in diesem frühen Stadium ohne Vorbehalt von den Verhandlungen zurückzutreten.

Unabhängig davon, wie erfolgreich ein Meeting war, ist es gut, an Ihre Gastgeber zu schreiben und ihnen für ihre Zeit und Mühe zu danken.

Geselligkeit und Gastfreundschaft tragen wesentlich zu guten Geschäftsbeziehungen in Slowenien bei. Slowenen genießen Geschäftsessen; für sie ist das Essen eine Gelegenheit, Themen in einer entspannten Atmosphäre zu diskutieren und ihre Partner und Kollegen auf einer persönlicheren Ebene kennenzulernen. Angesichts der Tatsache, dass Slowenen es vorziehen, Geschäfte mit einer Person zu besprechen, die sie kennen, können 
Entscheidungen bei gesellschaftlichen Anlässen genauso leicht getroffen werden wie in einer Büroumgebung.

Obwohl ein Treffen, um die Details der Geschäftsverhandlungen zu finalisieren, normalerweise in der formelleren Einstellung des Firmenbüros stattfindet. Die slowenischen Gastgeber erwarten von ihren Partnern, dass sie vorbereitet und zuversichtlich sind, ohne Vorurteile und verhalten sich verhalten. Alle Meinungen sollten präsentiert, aber nicht erzwungen werden, um den slowenischen Vertretern genügend Gelegenheit zu geben, ihre eigenen Ideen und Sichtweisen auszudrücken. Gleichheit, Respekt und Offenheit sind am Verhandlungstisch unerlässlich.

\section{Wie sind deutsche Geschäftsleute?}

In vielerlei Hinsicht können Deutsche als Meister der Planung angesehen werden. Dies ist eine Kultur, die vorwärts denken und wissen, was sie zu einem bestimmten Zeitpunkt an einem bestimmten Tag tun werden. Der deutsche Denkprozess ist äußerst gründlich, wobei jeder Aspekt eines Projekts sehr detailliert untersucht wird. Sorgfältige Planung, im Berufs- und Privatleben, gibt Sicherheit. Die meisten Aspekte des Lebens und Arbeitens in Deutschland sind durch Strukturen definiert und geregelt, zum Beispiel durch Gesetze, Regeln und Verfahren, die in allen wirtschaftlichen, politischen und sogar sozialen Bereichen sichtbar sind. Regeln und Vorschriften ermöglichen es den Menschen zu wissen, was erwartet wird, damit sie ihr Leben entsprechend planen können. Die Deutschen glauben, dass die Beibehaltung klarer Trennungslinien zwischen Menschen, Orten und Dingen der sicherste Weg ist, ein strukturiertes und geordnetes Leben zu führen. In der deutschen Geschäftskultur spiegelt sich dies in der Einhaltung vorgegebener Geschäftsregeln wider, die zu einem geringen $\mathrm{Maß}$ an Flexibilität und Spontanität in Einstellungen und Werten führen.

Deutsche mögen keine Überraschungen. Plötzliche Änderungen bei Geschäftsvorfällen, auch wenn sie das Ergebnis verbessern könnten, sind unerwünscht. Das Geschäft wird als sehr ernst betrachtet, und die Deutschen schätzen Humor im geschäftlichen Kontext nicht. Arbeit und Privatleben sind streng gespalten, und die Deutschen haben das Ideal, dass es für jede Aktivität einen angemessenen Ort gibt. 
Wenn Sie in Deutschland arbeiten, ist es wichtig, dass Sie schätzen, dass Business-Etikette für Ihr deutsches Pendant von großer Bedeutung ist. Deutschland ist eine Nation, die stark individualistisch ist und zu jeder Zeit höchsten Respekt verlangt, daher werden die höchsten Standards erwartet. Jedes unethische Verhalten wird alle zukünftigen Geschäftsverhandlungen ernsthaft mindern.

Die Deutschen fühlen sich am wohlsten, wenn sie ihre Welt in kontrollierbare Einheiten gliedern können. Zeit wird daher sorgfältig verwaltet, und Kalender, Zeitpläne und Tagesordnungen müssen respektiert werden. Züge kommen und gehen pünktlich zur Minute, Projekte werden sorgfältig geplant, und die Organisationspläne werden sorgfältig detailliert.

Kommen Sie nicht zu spät zu einem Termin oder wenn Sie Leute treffen. Deutsche sind extrem pünktlich, und sogar ein paar Minuten Verspätung können beleidigen. Wenn Sie noch etwas spät dran sind, rufen Sie uns an und erklären Sie Ihre Situation. Seien Sie fünf bis zehn Minuten zu früh für wichtige Termine.

Das Schenken unter Geschäftspartnern ist in Deutschland nicht üblich. In letzter Zeit gab es einen Schritt, sich viel mehr auf das eigentliche Geschäft zu konzentrieren und weniger auf Formalitäten und Rituale wie Geschenke bei Geschäftsreisen. Für soziale Anlässe ist das Schenken jedoch relativ üblich. Die folgenden Punkte sind wichtig, wenn Sie über ein Geschenk nachdenken:

- Ein Besucher, der über ein Geschenk nachdenkt, sollte sich für ein kleines und qualitativ gutes, aber nicht zu teures Produkt entscheiden.

- Akzeptable Geschenke bei Geschäftstreffen sind Bürogeräte, Stifte guter Qualität mit dem Firmenlogo oder Schnaps.

- Wenn Sie in ein deutsches Zuhause eingeladen werden, ist es angebracht, ein Geschenk mit Blumen, Wein, Pralinen oder einem kleinen Geschenk mitzubringen, das Ihr Heimatland oder Ihre Heimatregion darstellt.

- Deutschland hat im Allgemeinen die gleichen Traditionen wie die meisten anderen europäischen Länder in Bezug auf Schenkungen.

- Der erste Eindruck ist für die Deutschen sehr wichtig und kann sich auf das Ergebnis Ihrer Geschäftsbeziehung mit Ihrem deutschen Partner auswirken. Es gibt eine Reihe von verbalen und nonverbalen 
Kommunikationsproblemen, die Sie berücksichtigen sollten, wenn Sie Geschäfte mit einem Deutschen machen.

\subsection{Nonverbale Kommunikation}

- Großzügige persönliche Distanz wird zwischen Sprechern in einem Gespräch gefunden. Mindestens eine Armlänge zwischen zwei Lautsprechern wird allgemein erwartet.

- Augenkontakt wird erwartet und respektiert. Ununterbrochener Augenkontakt kann für diejenigen unangenehm sein, die an solche Etikette nicht gewöhnt sind; Augenkontakt zeigt jedoch Aufmerksamkeit und Interesse an einem Gespräch. Die Vermeidung des Blickkontakts kann in Deutschland als die gegenteilige Botschaft interpretierend interpretiert werden.

- Der direkte Augenkontakt ist besonders beim Toasten gegeben. ("Prost!" Beim Toasten mit Bier und "Zum wohl!" Beim Toasten mit Wein).

- Das deutsche Verhalten in der Öffentlichkeit ist in der Regel zurückhaltend und formal. So können das Winken und Geschrei einer weit entfernten Person negative Aufmerksamkeit erregen.

- Deutsche genießen Ruhe und Privatsphäre. Sie können so oft ihre Türen schließen, werden aber glücklich sein, Sie zu empfangen, wenn Sie an die Tür klopfen. Eine geschlossene Tür bedeutet nicht unbedingt, dass die Person nicht gestört werden kann.

- In einem Meeting-Kontext findet normalerweise ein Austausch von Visitenkarten statt. Karten müssen nicht unbedingt auf Deutsch gedruckt werden. Ein gutes Kartenangebot ist ratsam. Jeder Titel über einem Bachelor-Level sollte auf Ihrer Karte enthalten sein.

- Die Deutschen würdigen eine Präsentation am Ende eines Geschäftsmeetings, indem sie mit den Fingerknöcheln gegen die Tischplatte schlagen. 


\subsection{Verbale Kommunikation}

- Erwarten Sie nicht, nach 17 Uhr jemanden im Büro zu erreichen. Montag bis Donnerstag und nach 16 Uhr freitags.

- Wenn Sie in Deutschland telefonieren, ist es üblich, dass Sie sich mit Ihrem Nachnamen identifizieren.

- Deutsche sind gleichzeitig reserviert und direkt. Sie nehmen sich Zeit, um sich Ihnen zu nähern, während sie sofort ihre Gedanken sprechen. Seien Sie nicht beleidigt! Es ist kein persönlicher Angriff.

- Im allgemeinen Gespräch sind Deutsche sehr geradlinig und verwenden oft nur ein paar höfliche, gesprächige Sätze. In der Regel kommen sie ziemlich schnell auf den Punkt und erwarten Ergebnisse am Ende eines Meetings.

- Die meisten Geschäftsleute in Deutschland beherrschen sehr gut Englisch. Dennoch ist es empfehlenswert, die ersten Kontakte schriftlich in Deutsch zu machen - vorausgesetzt, Ihr Deutsch ist gut genug.

\subsection{Geschäftstreffen}

Deutsche schätzen Ordnung, Privatsphäre und Pünktlichkeit. Sie sind umsichtig und fleißig. Die Deutschen respektieren den Perfektionismus in allen Bereichen des geschäftlichen und privaten Lebens, und in ihrem Arbeitsansatz konzentrieren sie sich auf die Erfüllung der gestellten Aufgabe. Dies impliziert in Verbindung mit ihren klar definierten Strukturen, dass zwischenmenschliche Beziehungen im Geschäftsleben eine untergeordnete Rolle spielen. Es gibt eine strikte Trennung zwischen Privatleben und Arbeit in Deutschland und deshalb braucht es Zeit, um mehr persönliche Beziehungen zu schmieden. Geschäftsbeziehungen mit Deutschen basieren oft auf gegenseitigem Vorteil, wobei die Gesamtaufgabe im Mittelpunkt steht. Die Aufmerksamkeit für die zu erreichenden Ziele zeigt sich beispielsweise in der Genauigkeit der Zeitpläne, der Planung von Meetings und der Erreichung von Meilensteinen. Eine enge Einhaltung der Zeitpläne wird ebenfalls als wichtig erachtet.

Die Einhaltung des festgelegten Protokolls ist entscheidend für den Aufbau und die Pflege von Geschäftsbeziehungen in Deutschland. Als Gruppe sind die Deutschen suspekt gegenüber Übertreibungen, Versprechen, die zu gut klingen, 
um wahr zu sein, oder Anzeichen von Emotionen. Kommunikation ist sehr formell und die Deutschen neigen dazu, direkt zu sein, fast bis zur Unmittelbarkeit. Deutsche Geschäftsleute betreiben keine Politik der offenen Tür. Die Leute arbeiten oft mit geschlossener Bürotür und es wird erwartet, dass die Kollegen klopfen und darauf warten, eingeladen zu werden, bevor sie eintreten.

Die deutsche Geschäftskultur hat eine genau definierte und streng überwachte, vertikal strukturierte Hierarchie mit eng definierten Zuständigkeiten und Unterscheidungen zwischen Rollen und Abteilungen. Der Führungsstil hat den Ruf, relativ risikoscheu zu sein. Professioneller Rang und Status in Deutschland basiert im Allgemeinen auf der Leistung und dem Fachwissen eines Individuums in einem bestimmten Bereich. Akademische Titel und Hintergründe sind wichtig und vermitteln das Fachwissen und die gründliche Kenntnis des jeweiligen Arbeitsbereichs. Die Deutschen zeigen große Achtung vor Autoritätspersonen, daher ist es wichtig, dass sie Ihr Niveau relativ zu ihrem eigenen verstehen. In Deutschland gibt es ein Gefühl von Gemeinschaft und sozialem Gewissen und ein starkes Verlangen nach Zugehörigkeit. Unzulänglichkeit - auch im Scherz zuzugeben, ist unverständlich.

Erwarten Sie viel schriftliche Kommunikation, um Entscheidungen zu unterstützen und Entscheidungen und Diskussionen zu dokumentieren. Selbst wenn Sie eine freundschaftliche oder lockere Beziehung zu Kollegen haben, sollten Sie sich daran erinnern, dass eine Korrespondenz am Arbeitsplatz bedeutet, dass eine E-Mail ein Geschäftsbrief ist, in dem Begrüßungen und Grüße nicht vergessen werden sollten.

Wie bereits erwähnt, ist es in Deutschland üblich, bei Telefonanrufen Ihren Nachnamen anzugeben. In Übereinstimmung mit Corporate Identity-Trends ist die übliche Art, ein Telefon bei einer deutschen Firma zu beantworten, den Namen der Firma, den Namen der antwortenden Person und eine Begrüßung anzugeben.

Die Deutschen im Allgemeinen sind in Bezug auf körperliche Gestik typischerweise konservativ. Anders als in Frankreich küssen Männer nie, und öffentliche Anzeigen der Zuneigung sind nicht üblich, besonders in einer Geschäftsumgebung. Öffentliche Gesten der Zuneigung sind eher der engen 
Familie und Freunden vorbehalten. Die Deutschen werden normalerweise Fremde (in einem Geschäft zum Beispiel) anlächeln, um höflich zu sein, aber nicht beleidigt sein, wenn sie es nicht tun - das ist nur Teil einer allgemein zurückhaltenden Kultur.

Die Deutschen schätzen und halten einen größeren persönlichen Raum um sich herum als die Einwohner anderer europäischer Länder. Es ist jedoch nicht ungewöhnlich, dass die Deutschen, wenn sie Schlange stehen, um in einem Geschäft zu bezahlen, sehr nah an der Person vor ihnen stehen werden.

Höflichkeiten wie Händeschütteln und Höflichkeit gehen einen langen Weg, um Ihrem deutschen Gegenüber ein gutes Image zu geben. In Geschäftssituationen sollten Sie am Anfang und am Ende eines Meetings die Hände schütteln. Leute, die jahrelang zusammengearbeitet haben, geben sich jeden Morgen noch die Hand, als wären sie das erste Mal, dass sie sich getroffen haben. Zusätzlich kann ein Handschlag mit einer leichten Verbeugung einhergehen. Das Hin- und Herbewegen des Nackens ist eine gute Möglichkeit, einen guten Eindruck zu machen, da ein Versagen, mit diesem Kopfnicken (vor allem gegenüber einem Vorgesetzten) zu reagieren, einen schlechten Start haben kann. Achten Sie darauf, direkt in die Augen der Person zu sehen, während Sie die Hände schütteln. Wenn Sie einer Frau vorgestellt werden, warten Sie ab, ob sie ihre Hand ausstreckt.

Deutsche neigen dazu, oft Blickkontakt zu haben, also versuchen Sie es zu pflegen, wenn es mit Ihnen gemacht wird. Dies ist ein Zeichen der Aufmerksamkeit, also seien Sie nicht schnell davon ausgegangen, dass es sich um eine Drohgebärde handelt. Da dies nur ein Teil der Kultur ist, ist es nicht ungewöhnlich, dass auch auf der Straße Augenkontakt hergestellt wird, wiederum ohne Aggression. Expressive Verwendung der Hände ist in den meisten Gesprächen minimal. Verwenden Sie keine übertriebenen oder indirekten Kommunikationsstile bei Geschäftstreffen mit Ihren deutschen Kollegen. Es erzeugt einen Eindruck von Unaufrichtigkeit und Unehrlichkeit.

Da Geschäftsleute formal und konservativ sind, sind Geschäftsbeziehungen formell, geordnet und professionell. Behalten Sie die Hierarchie im Hinterkopf und richten Sie Ihre Nachricht immer an die entsprechende Person in der Organisation. 
Titel sind für Deutsche sehr wichtig. Tun Sie Ihr Bestes, um Menschen mit ihrem vollen, korrekten Titel anzusprechen, egal wie außergewöhnlich lang dieser Titel für Ausländer erscheint. Dies gilt auch, wenn Sie einen Brief adressieren.

Vornamen sind Familienmitgliedern und engen Freunden vorbehalten. In der deutschen Geschäftskultur ist es nicht ungewöhnlich, dass Kollegen, die jahrelang zusammengearbeitet haben, sich nicht bei ihren Vornamen nennen. Solange Sie nichts anderes wissen oder eine persönliche Beziehung entwickelt haben, ist es sehr wichtig, dass Sie sich auf Ihren deutschen Kollegen mit seinem Titel (bzw. Herrn und Frau für Herrn und Frau) und dem Nachnamen beziehen (verwenden Sie nicht den ersten Name, bis Sie eine Freundschaft haben). Wenn Ihnen jemand mit einem zusätzlichen Titel (z. B. Dr.) vorgestellt wird, verwenden Sie ihn.

Meetings werden in Deutschland ernst genommen und gehen möglicherweise sehr ins Detail. Geschäftstreffen folgen einem formellen Verfahren. Deutsche Manager arbeiten von präzisen und detaillierten Tagesordnungen, die normalerweise streng eingehalten werden; Darüber hinaus zielen Treffen immer auf entscheidende Ergebnisse ab, anstatt ein Forum für offene und allgemeine Diskussionen zu bieten. Die Formalität eines Treffens kann es für einen Außenstehenden schwierig machen, einzuschätzen, wie es läuft, aber eine langwierige Prüfung eines Vorschlags wird auf ernsthafte Absicht hindeuten.

Im deutschen Geschäftsverkehr ist es wichtig, solide Fakten und Beispiele zur Verfügung zu stellen, um die Vorschläge zu untermauern, da die Deutschen analytisches Denken und rationale Erklärungen bevorzugen. Verwenden Sie keine übertriebenen oder indirekten Kommunikationsstile bei Geschäftstreffen mit Ihren deutschen Kollegen, da dies mit Argwohn betrachtet wird. Die deutsche Geschäftskultur hat eine klar definierte und streng überwachte Hierarchie mit klaren Verantwortlichkeiten und Unterscheidungen zwischen

Rollen und Abteilungen. In formellen deutschen Geschäftstreffen ist es üblich, dass die ranghöchste Person zuerst den Raum betritt, nicht aber in informellen Geschäftssituationen. 
Wenn Sie ein Treffen mit Ihren deutschen Kollegen vereinbaren, müssen Sie eine Reihe von Punkten beachten, um das vorteilhafteste Ergebnis Ihrer Verhandlungen zu gewährleisten.

Überlegen Sie Folgendes, bevor Ihr Prozess beginnt:

Bei der Begrüßung von Personen in Deutschland, insbesondere bei Geschäftstreffen, ist es zwingend erforderlich, dass Sie immer Formalität verwenden. Folgende Punkte sind bei der Begrüßung der Deutschen von Bedeutung:

- Sie sind immer noch recht formell und mögen ihre Hierarchien. Daher werden Titel und Nachnamen häufig verwendet, wenn man eine Person und Geschäftsbeziehungen nicht kennt.

- Ein Mann sollte als Herr und Frau mit Frau angesprochen werden. In geschäftlichen Situationen ist es gut, den Ehrentitel und die Berufsbezeichnung zu verwenden. In zwangloseren Situationen, in denen der Nachname unbekannt ist, können nur Titel (Herr und Frau) verwendet werden.

- Die Deutschen bieten einen festen, aber kurzen Handschlag zur Begrüßung an. Der Händedruck wird oft mit "Guten Tag" begleitet. Manchmal wird "Hallo" (Hello) verwendet; im Süden sagt man "Grüß Gott". Es ist üblich, dass Menschen sich auch gegenseitig die Hand schütteln. In einigen deutschen Büros ist das Händeschütteln Teil des täglichen Rituals. Seien Sie also nicht überrascht, wenn eine Handschlagaktion dem Arbeitstag vorausgeht.

- Wenn Sie einen geschäftlichen Kontakt zum ersten Mal treffen, tauschen Sie Visitenkarten aus.

- Obwohl ein aufrichtiges Lächeln willkommen ist und die Menschen dazu neigen, höflich und gastfreundlich zu sein, können körperliche und emotionale Äußerungen bei der ersten Vorstellung auf ein Minimum reduziert werden. Im Laufe der Einführung und Konversation wird in der Regel Augenkontakt erwartet

- Deutsche sind dafür bekannt, dass sie direkt, aufrichtig und ehrlich darüber sind, wie sie sich fühlen; oberflächliche, kleine Gespräche werden selten begrüßt. Während eines Gesprächs wird von den Besuchern oft erwartet, dass sie ihre Meinung zu Themen wie Kunst und 
internationalen Ereignissen äußern. Sie sollten jedoch diskret sein, wenn politische Probleme auftauchen.

- Wenn enge Freunde einander begrüßen, ist es üblich, sowohl die linke als auch die rechte Wange zu küssen. Dies wird jedoch in einer Geschäftsumgebung als ungeeignet angesehen.

- Nicht alle Deutschen sprechen Englisch. Auch wenn Sie nicht sehr viel Deutsch

können, werden die meisten von Ihnen schätzen, dass Sie ihre Sprache lernen.

- Die effiziente Durchführung eines Treffens ist für Verhandlungen mit deutschen Partnern von entscheidender Bedeutung. Es zeigt Ihre Kompetenz, Motivation und Engagement für einen Deal und unterstreicht Ihre Professionalität.

Bei der Durchführung eines Meetings in Deutschland sind folgende Punkte zu beachten:

- Der Hauptzweck eines ersten Treffens ist es, sich kennenzulernen und die Person zu bewerten, Vertrauen zu gewinnen und die Chemie zu überprüfen.

- Termine in Deutschland sind verpflichtend und Treffen in deutschen Unternehmen werden in der Regel weit im Voraus geplant.

- Es empfiehlt sich, Termine einige Wochen vorher per Telefon oder Fax zu vereinbaren. Bis zu vier Wochen können Sie Termine vereinbaren, wenn Sie die Mail benutzen. Kurze Vorbesprechungen können manchmal kurzfristig vereinbart werden.

- Versuchen Sie, Geschäftstreffen in den Monaten Juli und August oder um die Feiertage herum zu vermeiden.

- Der Planungsprozess ist oft sehr zeitaufwendig. Sobald dies jedoch vorbei ist, wird sich ein Projekt sehr schnell entwickeln und es wird erwartet, dass die Fristen eingehalten werden.

- Briefe sollten an die Hauptperson im Funktionsbereich adressiert werden, einschließlich des Namens der Person sowie ihres richtigen Geschäftstitels. Rank ist sehr wichtig in der deutschen Wirtschaft. Richten Sie niemals ein Treffen für einen Mitarbeiter mit niedrigerem Rang ein, um sich mit einer höherrangigen Person zu treffen. 
- Wenn Sie schreiben, um einen Termin zu vereinbaren, sollte der Brief in Deutsch geschrieben werden.

- Eine zügige Korrespondenz ist zwingend erforderlich. Telefonanrufe und Faxe sollten umgehend zurückgegeben werden.

- Obwohl Deutsch die bevorzugte Geschäftssprache ist, sind die meisten oberen

Führungskräfte in der Lage, ein Gespräch auf Englisch zu führen.

- Pünktlichkeit wird sehr ernst genommen. Wenn Sie mit einer Verzögerung rechnen, rufen Sie sofort an und bieten Sie eine Erklärung an. Es ist äußerst unhöflich, ein Meeting in letzter Minute abzubrechen und es könnte Ihre Geschäftsbeziehung gefährden.

- Die Treffen sind in der Regel formell und die ersten Treffen dienen dem gegenseitigen Kennenlernen der Parteien. Sie erlauben Ihren deutschen Kollegen, festzustellen, ob Sie vertrauenswürdig sind.

- Die Teilnehmer müssen pünktlich ankommen und sich verkleiden, anstatt sich zu dieser Gelegenheit niederzulegen.

- Wie in den meisten europäischen Ländern, ist die Etikette für Meetings in Deutschland auf Professionalität, guten Geschäftssinn und Formalität angewiesen. Vor diesem Hintergrund werden zusammen mit einer positiven Einstellung gute Ergebnisse sichergestellt. Bei Geschäftsverhandlungen mit deutschen Geschäftsleuten müssen Sie einige wichtige Punkte beachten, um ein positives Verhandlungsergebnis zu erzielen.

- Deutsche sind wettbewerbsfähige, ehrgeizige und harte Partner.

- In der deutschen Wirtschaft gelten das Wort und der Händedruck einer Person als seine Bindung. Wenn in einer Geschäftssitzung eine mündliche Vereinbarung getroffen wird, gilt diese im Allgemeinen als verbindlich.

- Geschäftsverhandlungen neigen dazu, analytisch und sachlich zu sein.

- Eine gut recherchierte Rede mit vielen Graphen, empirischen Argumenten und Statistiken wird normalerweise bevorzugt. Ein direkter, sachlicher Ansatz wird am meisten geschätzt.

- Geschäft ist hierarchisch. Die Entscheidungsfindung findet auf den höchsten Ebenen des Unternehmens statt, d. h. von oben nach unten. Es ist nicht angemessen, einen gleichrangigen Mitarbeiter durch 
Beratung mit seinem Vorgesetzten zu umgehen, auch wenn die Verhandlungen lange dauern.

- Autorität wird abgelehnt.

- Entscheidungsfindung ist oft ein langsamer und detaillierter Prozess. Erwarten Sie keine wesentlichen Schlussfolgerungen, die auf spontanen oder unstrukturierten Ergebnissen beruhen. Jeder Aspekt der von Ihnen vorgeschlagenen Transaktion wird von vielen Führungskräften behandelt. Erwarten Sie nicht, diesen Prozess beschleunigen zu können.

- Daher ist die Entscheidungsfindung während der Verhandlungen langsamer als in einigen anderen europäischen Ländern. Ein ungeduldiger Unternehmer wird wahrscheinlich nicht den gleichen Respekt wie ein geduldiger, vernünftig gesprochener Mensch haben. Wenn sich die Deutschen zu einem Geschäftsabschluss hinreißen lassen, könnten sie dies als Mangel an Engagement und Professionalität empfinden.

- Sie müssen geduldig sein und dürfen durch die strikte Einhaltung des Protokolls weder verwirrt noch gereizt sein. Die Deutschen sind detailorientiert und wollen jede Andeutung verstehen, bevor sie zu einer Einigung kommen.

- Die Deutschen haben eine Abneigung gegen divergierende Meinungen, verhandeln und debattieren jedoch leidenschaftlich.

- Vermeiden Sie konfrontatives Verhalten oder Hochdruck-Taktiken. Es kann kontraproduktiv sein. Vermeiden Sie widersprüchliche Aussagen, z. B. nach einem

- Kompliment mit einer Beschwerde.

- Witze, Anekdoten, ein "Hard-Sell"-Ansatz (der eine Beleidigung eines Konkurrenten bedeuten kann) oder spontane Präsentationen werden im Allgemeinen als unangemessen betrachtet. Umgangssprache und umgangssprachliche Ausdrücke sollten auf ein Minimum oder noch besser, überhaupt nicht verwendet werden.

- Entscheidungen werden oft informell diskutiert und werden in der Regel vor den Sitzungen mit der Einhaltung getroffen, anstatt dass der Konsens in der Sitzung erwartet wird.

- Abschließende Entscheidungen werden in rigorose, umfassende Handlungsschritte umgesetzt, von denen Sie erwarten, dass sie genauestens ausgeführt werden. 
- Sobald eine Entscheidung getroffen wurde, wird sie nicht geändert. Ihre Aufmerksamkeit für Details wird von Ihren deutschen Kollegen nicht unbemerkt bleiben und wird Ihre echte Bereitschaft und Begeisterung zeigen, mit ihnen Geschäfte zu machen.

Sitzungsprotokoll.

- Meetings folgen strikten Tagesordnungen, einschließlich Start- und Endzeiten.

- Senden Sie Firmenprofile, persönliche Profile usw. vor Ihrem Besuch an deutsche Kollegen, um Glaubwürdigkeit zu erlangen.

- Kommen Sie gut vorbereitet zu den Sitzungen. Vermeiden Sie harte Verkaufstaktiken oder Überraschungen.

- Schriftliche oder mündliche Präsentationen sollten spezifisch, sachlich, technisch und realistisch sein.

- Stellen Sie sicher, dass Ihr gedrucktes Material sowohl in Englisch als auch in Deutsch verfügbar ist.

- Berichte, Briefings und Präsentationen sollten durch Fakten, Zahlen, Tabellen und

Diagramme unterstützt werden.

- Deutsche verabscheuen Übertreibung. Stellen Sie sicher, dass Sie Ihre Ansprüche mit vielen Daten sichern können. Fallstudien und Beispiele werden hochgeschätzt.

- Deutsche fühlen sich nicht wohl mit dem Unerwarteten. Die Pläne sind zurückhaltend, mit Rückzugspositionen, Notfallplänen und umfassenden Handlungsschritten.

- Behalten Sie während des Sprechens direkten Blickkontakt.

- Obwohl Englisch gesprochen werden kann, ist es ratsam, einen Dolmetscher zu engagieren, um Missverständnisse zu vermeiden.

- Am Ende eines Treffens signalisieren einige Deutsche ihre Zustimmung, indem sie mit den Fingerknöcheln auf die Tischplatte klopfen.

Da deutsche Geschäftsleute sehr förmlich sind, wird das Zusammensein nach den Treffen erst stattfinden, wenn feste Arbeitsbeziehungen hergestellt sind. Während in den Geschäftsbeziehungen ein gewisses $\mathrm{Maß}$ an Formalismus bestehen bleibt, werden Bemühungen, ein Gefühl für die deutsche Sprache und Kultur zu entwickeln, die Beziehungen erheblich verbessern. 
Die Deutschen genießen es, gastronomische Genüsse mit einem interessanten Gespräch über mögliche Geschäfte zu verbinden. Das eigentliche Geschäft sollte jedoch nicht während eines Mittag- oder Abendessens durchgeführt werden. Das Teilen einer Mahlzeit soll helfen, eine persönliche Bekanntschaft zu begründen, und es ist Zeit, gutes Essen, Wein und Gespräche zu genießen.

- Die Deutschen schätzen ihre Privatsphäre und ihren persönlichen Raum immens. Stellen Sie keine persönlichen Fragen zu Beruf, Gehalt, Alter, Familie oder Kindern, auch wenn Sie eine gut etablierte Freundschaft pflegen.

- Begrüßen Sie immer zuerst Frauen in Deutschland.

- Seien Sie nicht beleidigt, wenn jemand Ihr Verhalten korrigiert (d. H. eine Jacke in einem Restaurant auszieht, an der falschen Stelle parkt usw.). Sich gegenseitig zu überwachen, wird als soziale Pflicht angesehen.

- Komplimente soll man sorgfältig und sparsam machen- es kann in Verlegenheit bringen.

- Verlieren Sie Ihre Wut nicht öffentlich. Dies gilt als ungehobelt und als Zeichen der Schwäche.

- Stehen Sie auf, wenn eine ältere oder höher eingestufte Person den Raum betritt, um ihn / sie zu begrüßen.

- Traditionell ist die Akzeptanz von Frauen in hohen Positionen der Verantwortung und der Macht in der Wirtschaft gering. Frauen, insbesondere ausländische Frauen, müssen sofort ihre Position und Fähigkeit aufbauen, um bei einer erfolgreichen Geschäftstätigkeit in Deutschland ernst genommen zu werden.

\section{$4 \quad$ Fazit}

Es wurden viele Beispiele gegeben, wie slowenische, bzw. deutsche Geschäftsleute sind, bezogen auf verschiedene Situationen in Unternehmen. Bei den Vorlesungen wird jede geschäftliche Situation schriftlich und mündlich "vorgespielt". Nur so kann man sicher sein, dass später, im wirklichen Leben, weniger Fehler vorkommen und gemacht werden. 
Wo sind also die Unterschiede? Die Frage könnte am besten mit einer anderen Frage beantwortet werden, und zwar:

Worauf sollten Geschäftsleute also achten, wenn ihre Geschäftspartner und Kollegen einen anderen kulturellen Background haben? "Bezogen auf die deutschen Kulturstandards ist die erste Regel, dass man sich so höflich, so vorsichtig und so rücksichtsvoll wie nur möglich benimmt und ausdrückt. Denn nur so bremsen wir so manche unserer Schärfen ab, die wir zwar nicht so meinen, aber die beim anderen so ankommen können." (Schroll-Machl, 2003)

Schroll-Machl (2003) rät, viel Zeit mit Beobachten und Zuhören zu verbringen. "Nur so kann man einen Blick dafür entwickeln, wann man etwas angestellt haben könnte. Dann ist der erste Schritt bereits getan, um ein interkulturell bedingtes Missverständnis aus dem Weg zu räumen."(Schroll-Machl, 2003)

\section{Literatur und Quellen}

Kets, F. R. M. (2012, 30. Juli). Was sind die Stäken dentschen Manager? Abgerufen von: http://www.harvardbusinessmanager.de

Werner K. (2013, 3. August). Deutsche Manager im Ausland. Abgerufen von: http://www.sueddeutsche.de

Dunkl, A. (2013, 25. November). Slowenische Chefs führen gesünder. Abgerufen von: http://www.derstandard.at

Verle, K., Markič M., Kodrič B. (2012, 1. Januar). Kompetence slovenskib managerjev. Abgerufen von: http://organizacija.fov.uni-mb.si

Schroll-Machl, S. (2003, 7. November). Typisch dentsch? Wie wir auf ausländische Geschäftspartner wirken. Abgerufen von: http:// www.goingglobal.de

Schroll-Machl, S. (2003). Die Deutschen - Wir Deutsche Fremdwahrnebmung und Selbstsicht im Berufsleben. Göttingen, Germany: Vandenhoeck Ruprecht. 


\title{
The Writing Skill Needs Analysis in a Professional Context: A Case Study of Hotel Employees
}

\author{
Dragana VuKović VojnOVić \& JelEna JERKOVIĆ
}

\begin{abstract}
In this paper, we have been interested in the writing skill needs in the hospitality context. In particular, the study has focused on obtaining information on specific tasks and activities within the writing skill that hotel employees are expected to use in a professional context in different hotel departments. Twenty hotel employees have been asked to complete a standardized questionnaire on the frequency of particular writing tasks they perform in English as part of their daily duties in a hotel in Serbia. Some of the interviewees are also specialist subject teachers in a hospitality high school in Belgrade. It has been expected that writing skills in English are not required in certain hotel departments, whereas particular job positions involve more elaborate writing tasks, depending on the job requirements. Finally, the paper will show how the research results and collected information can be implemented in developing tailor-made ESP course design.
\end{abstract}

Keywords: • ESP course design $\bullet$ tourism \& hospitality $\bullet$ needs analysis $\bullet$ target-situation analysis $\bullet$ writing skill $\bullet$

CORRESPONDENCE ADDRESS: Dragana Vuković Vojnović, MA Philology, Senior English Lecturer, University of Novi Sad, Faculty of Sciences, Trg Dositeja Obradovića 3, Novi Sad, Serbia e-mail: vukovic.vojnovic@gmail.com. Jelena Jerković, PhD Linguistics, Assistant Professor, University of Novi Sad, Faculty of Technology, Bulevar Cara Lazara 1, Novi Sad, Serbia e-mail: jemit@uns.ac.rs. 


\section{Introduction}

The process of globalization in the world has been developing rapidly in recent years. In the economic and tourism sectors, according to World Trade Organisation (WTO), the requirement of the English language for cross border trade and tourism has become the mainstream (Liao et al., 2017, p. 1). Since the tourism industry has flourished recently all over the world, the use of English in this branch plays a vital role. However, the gap between the studying process at universities and colleges and the needs of the job market still exists. In order to explore the needs and problems of the college learners, needs analysis plays a crucial role in developing English for specific purposes curriculum (Prachanan, 2012).

From another point of view, Graddol mentions (2006, p. 18) that English changed its status from a 'foreign language' to a basic skill, which is particularly true for the field of travel and tourism where non-native English speakers use English as a lingua franca. This fact has influenced the process of teaching and learning English as people have been motivated by both professional and personal reasons to study it. In view of this, a great necessity has developed for tailor made courses to match the exact needs of prospective language learners. In this paper, we focused on the target-situation analysis specifically related to the writing skill tasks performed by hotel employees. The results should help us develop more practical and relevant tasks and activities for the employees as well as for the students of tourism and hospitality in order to prepare them better for their future professional life.

\section{$2 \quad$ Needs analysis within the writing skill}

Needs analysis has been one of the key elements and an integral part of English for specific purposes (ESP) practitioners i.e. researchers, course designers, material developers, testers, evaluators as well as classroom teachers for many years (Wannapok, 2004). In the ESP context, it especially refers to a course development process and at the same time it involves several analyses (Basturkmen, 2010, p. 19): 
- Target situation analysis: identification of tasks, activities and skills learners will be using English for, i.e. what the learners should ideally know and be able to do.

- Discourse analysis: descriptions of the language used in a professional context.

- Present situation analysis: identification of learners' level of knowledge in relation to the demands of the target situation.

- Learner factor analysis: identification of learners' factors such as motivation, learning strategies and their perceptions of their needs.

- Teaching context analysis: identification of factors related to the environment in which the course will be run.

Obviously, needs analysis has become a very complex, multi-layered procedure. In this paper, we will focus only on the target situation analysis, especially on the writing skill tasks performed by hotel employees.

Apart from the reading skill, which is according to many authors the most needed skill in EAP and ESP courses (Jordan, 1997; Robinson, 1991), the second place is taken by productive language skills - writing and speaking. In order to perform written communication and become understandable to readers, it is necessary for students to acquire the main rules of written language, especially grammar, spelling, style, as well as to learn and use appropriate terminology. In addition to necessary educational content in the respective fields of study, an ESP course has to include content which provides students with the basic language knowledge as follows:

- first of all, basic characteristics of specialist register, typical grammatical structures and specific discourse (in this case hospitality and tourism) and

- secondly, the most frequent written forms which they will often encounter in their future professions, in our case, as hotel employees.

In order to achieve a balanced ESP course at tertiary level, it is vital to determine how often the writing skill is used by hotel employees in an average-sized local hotel for the purpose of their job as well as which particular tasks and activities are most often used. 


\section{$3 \quad$ Research Methodology}

\subsection{Research Objectives and Procedure}

The main objective of this research was to find out how often hotel employees in an average-sized local hotel wrote in English for the purpose of their job. Moreover, we wanted to find out which particular tasks and activities were of greater importance to them and whether there were any differences across hotel departments. The first part of the questionnaire dealt with more general questions about the use of English in their workplace, the importance of English and other languages for professional purposes and the second part of the questionnaire investigated how often they performed more specific writing tasks and activities in English. In this part, they were given a list of tasks to be ranked from 4 to 1 according to the frequency of the task: 4 - often, 3 - sometimes, $2-$ rarely and $1-$ never. Here are some of the questions included in the list:

- Writing instructions about the payment method

- Writing a hotel description for the website presentation

- Confirming the reservation by email

- Emailing a job application

- Completing a form

- Promotional letters

- A welcome letter for guests

- Writing a project proposal

\subsubsection{Research Participants}

Twenty employees in the Hotel Palace in Belgrade were interviewed, fifteen employees belonged to the Reception Department which also included five room attendants and the head housekeeper, as well as one hospitality teacher, and five restaurant employees including two hospitality and catering teachers. They were asked to complete a questionnaire on the importance and use of English in their workplace with particular emphasis on written tasks. The chosen hotel is also an educational centre for the students of the Hospitality and Tourism School in Belgrade, so, as it was mentioned, some of the employees in the restaurant and reception area are also high school subject teachers with three of them being 
mainly teachers supervising student practice. A brief look into the participant demographics shows that $40 \%$ of them have a high school degree including all room attendants, a telephone operator, a night porter and one waiter, followed by employees with a university degree $(35 \%)$ - three receptionists, a head receptionist, a reservations manager, a restaurant manager and one teacher and finally, a three-year college degree was obtained by $25 \%$ of staff - one receptionist, one waiter, two teachers/waiters in the restaurant and a head housekeeper.

As we observed overall results of the questionnaire, it turned out that room assistants never wrote in English for the purpose of their jobs. This was also true for the three teachers who in rare occasions used English but were not required to write in English for their jobs. This was understandable because their main responsibilities were to supervise students and they were not fully immersed in hotel operations. We decided to include the data obtained from these employees only in the analysis of the first part of the questionnaire. Regarding the frequency of specific written tasks and activities in English that were included in the second half of the questionnaire, they all said that they never performed any of the given written tasks in English.

\section{$4 \quad$ Results and Discussion}

According to our research design and purpose, we asked how often hotel staff used English in their job, and the average answer was 3.55 (on the scale from 1 to 4) for all participants and if we look at reception staff only the answer was 4, meaning that they all used English often within the professional context. This refers to the use of English in general and for any professional purposes and not only for written tasks. We can conclude that for hotel staff in this hotel it is rather important to be able to communicate in English in their workplace. However, later in the discussion we will show great differences among individual employees who clearly have completely different language needs related to their hotel duties.

Out of those who used English in their job, most of them said they needed it often (60\%), followed by sometimes $(35 \%)$ and rarely $(5 \%)$. As it has already been mentioned, some employees never wrote in English in professional context so their answers were not processed further in the research of specific writing tasks. 
Employees were also asked what other foreign languages (apart from English) they used in the professional context, with the possibility of choosing more than one language. It was found that they mostly used German and Russian (35\%), followed by French $(20 \%)$ and Italian $(15 \%)$, with six employees not using other languages.

Regarding more specifically their writing practice in English, we have come up with overall results shown in Table 1. For this question, they could choose more than one answer. As it can be observed, they mostly wrote directly in English using model texts, which can be explained by recurring typical texts they needed to write, and 30\% translated the texts from Serbian. Five room assistants never wrote in English as part of their job, which was expected.

Table 1: Writing habits in English for professional purposes

\begin{tabular}{|l|c|c|}
\hline LABEL & FREQUENCY & PERCENTAGE \\
\hline Writing directly in English & 7 & $35 \%$ \\
\hline Translating from Serbian & 6 & $30 \%$ \\
\hline Using a model text in English & 7 & $35 \%$ \\
\hline Never writing in English & 5 & $25 \%$ \\
\hline
\end{tabular}

Regarding their translation habits, the employees could also choose more than one answer. It appears that they mostly translated the texts on their own with a help of some colleagues or consulting a dictionary (Table 2). Sometimes they used available automatic translation on the Internet and four of them said that they never translated for the purpose of the job (all four were room assistants). It is interesting to observe that they never hired professional translators.

Table 2: Translation habits in English for professional purposes

\begin{tabular}{|l|c|c|}
\hline LABEL & FREQUENCY & PERCENTAGE \\
\hline Translating on their own with a dictionary & 8 & $40 \%$ \\
\hline Hiring professional translators & 0 & $0 \%$ \\
\hline Translating with a help of my colleagues & 8 & $40 \%$ \\
\hline $\begin{array}{l}\text { Using automatic translation, e.g. Google } \\
\text { Translate }\end{array}$ & 4 & $20 \%$ \\
\hline Never translating & 4 & $20 \%$ \\
\hline
\end{tabular}




\subsection{Specific written tasks needed by hotel employees}

Before we looked into the results regarding specific written tasks needed in an average local hotel, we analysed individual needs for all the employees so that prospective teaching materials could be tailor-made to suit them individually. We also noticed that some hotel departments and some employees did not need to write for the purpose of their job at all. This included room assistants and specialist subject teachers. On the other hand, some employees had assigned higher values to specific tasks, which could be directly related to their job rank and position. These employees belong to senior staff members and their job description and duties require much more writing in English than it is needed for other jobs. As we can see from Table 3, the results for reception staff show that the Head Receptionist is in the first place with the average score of 3.7, which means that he performed almost all of the 26 written tasks in English often (mark 4) or sometimes (mark 3). The Reservations Assistant, two receptionists and the Head Housekeeper also needed writing skills much more than it was the case with other members of staff. The Hospitality Teacher who is responsible for student practice within the Reception Department never wrote in English as part of their job (mark 1).

Table 3: Individual writing needs of reception staff

\begin{tabular}{|l|c|}
\hline JOB POSITION & $\begin{array}{c}\text { TASK } \\
\text { FREQUENCY }\end{array}$ \\
\hline Head Receptionist & 3.7 \\
\hline Reservations Assistant & 2.9 \\
\hline Receptionist & 2.89 \\
\hline Head Housekeeper & 2.73 \\
\hline Receptionist & 2.61 \\
\hline Receptionist & 1.84 \\
\hline Porter & 1.61 \\
\hline Receptionist & 1.56 \\
\hline Telephone Operator & 1.5 \\
\hline Hospitality Teacher & 1 \\
\hline
\end{tabular}

In this part, we will look into the specific written tasks performed in English by reception staff. When we compared the overall average results with those obtained from the restaurant staff, we saw that the latter group almost did not write in English because 1.6 was the highest average mark given. On the other 
hand, reception staff valued written activities with much higher marks. Furthermore, we observed that some of the written activities were performed more often than others and thus should be given more attention in the future course design. There is also a call for integrated skills (e.g. listening and writing for note-taking during a telephone conversation). In the following table (Table 4) we summarized written activities/tasks which were most frequently needed by reception staff with the average mark for their frequency.

Table 4: The most frequent written activities performed in English by reception staff

\begin{tabular}{|l|c|}
\hline WRITTEN ACTIVITY & $\begin{array}{c}\text { AVERAGE } \\
\text { FREQUENCY }\end{array}$ \\
\hline $\begin{array}{l}\text { Note-taking during a telephone } \\
\text { conversation }\end{array}$ & 3.2 \\
\hline $\begin{array}{l}\text { Written reservation confirmation (letter or } \\
\text { email) }\end{array}$ & 2.9 \\
\hline $\begin{array}{l}\text { Describing a hotel or a destination for a } \\
\text { travel brochure or a website }\end{array}$ & $2.7 / 2.5$ \\
\hline Writing a welcome letter & 2.7 \\
\hline $\begin{array}{l}\text { Writing an email or a letter recommending } \\
\text { the hotel }\end{array}$ & 2.5 \\
\hline $\begin{array}{l}\text { Writing an email or a letter offering special } \\
\text { services }\end{array}$ & 2.4 \\
\hline Writing payment procedure instructions & 2.4 \\
\hline $\begin{array}{l}\text { Writing short announcements for the } \\
\text { information board }\end{array}$ & 2.3 \\
\hline
\end{tabular}

To sum up the research results, we can conclude that three things became obvious:

- Room attendants and specialist subject teachers never wrote in English as part of their job.

- Reception staff needed writing more than the other departments - when compared to combined results for all staff.

- Staff members at senior, managerial positions performed written tasks in English significantly more often than other employees. 


\section{$5 \quad$ Conclusion and further implications}

A general conclusion stemming from the conducted needs analysis showed that ESP curriculums should be modified due to specific needs of the job market and the scale of operations within hotels. In our future analysis, it would be interesting to compare the obtained results of a medium-sized hotel with those that would be obtained in a large international hotel chain. We could expect differences across hotel departments as well as among individual members of staff due to differences in the hotel processes and procedures.

In our study, it was clearly shown that specific professions needed very specific written activities such as note-taking during a telephone conversation, writing a reservation confirmation or explaining payment procedure in written form to prospective guests. Such activities and skills should be thoroughly analyzed and broken into smaller chunks to be included into a future ESP course design. Finally, university courses are only the first step in learning specific work-related tasks to be performed in English, so most of them would be practised further within the in-house training courses.

Although it was established that English language skills were generally needed by all tested staff members (average mark 3.55), the writing skill needs depended on the job description and rank as well as on the hotel department operations. As the respondents were of the higher rank, they needed more specific writing skills as well as integrated skills for the purpose of their job (e.g. head receptionist mark 3.7, waiter - 1.5). On the other hand, the results showed that room assistants did not write in English within their jobs, unlike the head housekeeper and reception staff that needed more advanced command of the writing skill for their regular operations.

To sum up, the mentioned gap between studying process at universities and the needs of the real job market can be bridged by continuous reviewing and analysing the needs of the dynamic tourism industry market. The right balance can be achieved by follow-up in-house training courses that would use specific tailor-made tasks and activities. 


\section{References}

Basturkmen, H. (2010). Developing English courses in English for specific purposes. New York: Palgrave Macmillan.

Graddol, D. (2006). English next. The United Kingdom: British Council.

Jordan, R. R. (1997). English for academic purposes. Cambridge: Cambridge University Press. Liao, T. T., Hsu, P. Y., Lee, C. L., \& Yang, K. F. (2017). English for specific purpose for EFL college interns in international tourism industry in Taiwan: needs analysis and challenges. International Journal of Management and Applied Science, 3(7), 58-63.

Prachanan, N. (2012). Needs analysis on English language use in tourism industry. Procedia Social and Behavioral Sciences, 66, 117-125.

Robinson, P. (1991). ESP today: a practitioner's guide. Hemel Hempstead: Prentice Hall.

Wannapok, S. (2004). A study of English for business and technology students' attitudes towards the English for business and technology program at the University of the Thai Chamber of Commerce (Independent Study). Bangkok, Thailand: University of Thai Chamber of Commerce. 

In today's highly globalised economy speakers of different languages and respective cultures meet and communicate on a daily basis. Hence, it is of paramount importance that formal education at all levels fosters foreign language skills informed by intercultural competence that today's students will need when joining the job market and pursuing their professions. To best cater for the needs of students of different professions, language teaching and learning needs to be adapted to the specific needs of individual professions as well as current and emerging trends in language pedagogy.

The exploration and dissemination of relevant expertise and good practice in the field of foreign language pedagogy is the main aim of these proceedings, which include the papers of the $10^{\text {th }}$ International Language Conference on "The Importance of Learning Professional Foreign Languages for Communication between Cultures" held on 20 and 21 September 2018 at the University of Maribor, Faculty of Logistics.

\section{Conference Partner}

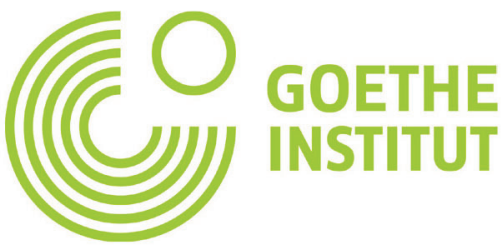

Conference Sponsor

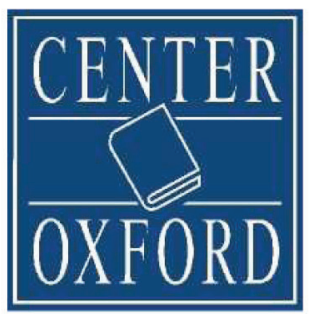

Mladinska knjiga

TRGOVINA 